UNIVERSIDADE DE SÃO PAULO

FFCLRP- DEPARTAMENTO DE PSICOLOGIA E EDUCAÇÃO

PROGRAMA DE PÓS-GRADUAÇÃO EM PSICOLOGIA

\title{
A biblioteca escolar nas teias do discurso eletrônico
}

Ludmila Ferrarezi

Dissertação apresentada à Faculdade de Filosofia, Ciências e Letras de Ribeirão Preto da USP, como parte das exigências para a obtenção do título de Mestre em Ciências, Área: Psicologia

Ribeirão Preto- SP 


\section{LUDMILA FERRAREZI}

\section{A biblioteca escolar nas teias do discurso eletrônico}

Dissertação apresentada à Faculdade de Filosofia, Ciências e Letras de Ribeirão Preto da USP, como parte das exigências para a obtenção do título de Mestre em Ciências, Área: Psicologia

Orientadora: $\operatorname{Prof}^{\mathrm{a}} \operatorname{Dr}^{\mathrm{a}}$ Lucília Maria Sousa Romão

Ribeirão Preto- SP 
Autorizo a reprodução e divulgação total ou parcial deste trabalho, por qualquer meio convencional ou eletrônico, para fins de estudo e pesquisa, desde que citada a fonte.

Ferrarezi, Ludmila

A Biblioteca escolar nas teias do discurso eletrônico. Ribeirão Preto, 2010.

200 p. : il. ; $30 \mathrm{~cm}$

Dissertação de Mestrado, apresentada à Faculdade de Filosofia, Ciências e Letras de Ribeirão Preto/USP. Área de concentração: Psicologia.

Orientadora: Romão, Lucília Maria Sousa.

1. Biblioteca escolar. 2. Discurso. 3. Internet. 


\section{FOLHA DE APROVAÇÃO}

\section{Ludmila Ferrarezi}

A biblioteca escolar nas teias do discurso eletrônico

Dissertação apresentada à Faculdade de Filosofia, Ciências e Letras de Ribeirão Preto da Universidade de São Paulo, como parte das exigências para a obtenção do título de Mestre em Ciências, Área de Concentração: Psicologia.

Aprovado em:

1

\section{Banca Examinadora}

Prof. Dr.

Instituição:

Assinatura:

Prof. Dr.

Instituição: Assinatura:

Prof. Dr.

Instituição: Assinatura: 
Dedico este trabalho a todos aqueles que compartilham um querer fazer/saber diferente, que nos remeta a um tempo de sonhos infantis, em que as "bibliotecas, antes de serem estas infinitas estantes, com as vozes presas dentro dos livros, foram vivas e humanas, rumorosas, com gestos, canções, danças entremeadas às narrativas" (MEIRELES, 1984, p.49) 


\section{AGRADECIMENTOS}

"O que vale na vida não é o ponto de partida e sim a caminhada. Caminhando e semeando no fim terás o que colher" (CORALINA, 1987, p.63)

Agradeço a todos aqueles que fazem essa minha caminhada valer a pena:

À professora Soraya Maria Romano Pacífico, por fazer parte das tramas de sentidos que teci, ao longo de todo meu percurso acadêmico, pelas contribuições valiosas para o meu trabalho, pelo carinho, excelência, generosidade e delicadeza que dedica a tudo o que faz

À professora Magda Teixeira Chagas, pela leitura atenta, pelo modo gentil e receptivo como acolheu essa pesquisa e, também, pelas relevantes considerações que me ajudaram a construíla

Aos meus pais, que me proporcionaram muito mais do que a vida... por serem o esteio que sempre sustentou meus movimentos em direção ao saber, pela paciência, incentivo e apoio incondicional nos momentos difíceis

À minha irmã Lígia, por ser essa interlocutora sagaz, interessada e paciente, pelo apoio e por acreditar em mim

À minha tia Maria, por ter incentivado, ainda nos meus primeiros anos de vida, o gosto pela leitura e a busca pelo conhecimento, além de todo o apoio no meu percurso acadêmico, que me permitiu chegar até aqui

À minha avó Catarina, por fazer a vida mais doce e ser uma inspiração de força e paciência

A todos os meus amigos, companheiros de longa data que trazem alegria à minha vida, agradeço pelos momentos felizes, por compreenderem os meus "furos" e ausências, pelo incentivo e por compartilharem a vida! Agradeço especialmente à Evelyn, Fernanda, João, Leandro, Patrícia, Susana, Thaís e Willian, por acompanharem de perto a feitura deste trabalho

A todos os amigos do grupo de estudos, pelos saberes e momentos alegres compartilhados, especialmente, Ane, Cynara, Dani, Elis e Juliana, pelo carinho que nos une nessas teias da Análise do Discurso

A todos os amigos do CID/USP, com os quais compartilho as delícias e dificuldades de ocupar esse "lugar de entremeio"

Aos funcionários da USP, especialmente Inês e Isilda, pela ajuda concedida e o atendimento eficiente e cordial

À FAPESP (Fundação de Amparo à Pesquisa do Estado de São Paulo), pela bolsa de mestrado concedida (Processo ${ }^{\circ}$ 08/50793-9)

A todos que, direta ou indiretamente, contribuíram para a realização desta pesquisa 


\section{UM AGRADECIMENTO ESPECIAL}

"A ciência pode classificar e nomear os órgãos de um sabiá, mas não pode medir seus encantos."

(BARROS, 1996, p. 53)

Agradeço especialmente à Lucília, que, nesses últimos seis anos, foi além em suas ações: foi professora com paixão e orientadora com excelência, que soube conduzir-me com sabedoria, respeito e afeto; foi, ainda, propulsora de muitos vôos; companheira de tantos momentos de estudo, crescimento, descobertas e alegrias, compartilhando sentidos sobre o discurso, a rede, a biblioteca escolar e a vida.

Foi ela que lançou as sementes do fruto que colho agora, que me fez pesquisadora, de forma tão generosa e acolhedora, que me apresentou um novo olhar, não só para as palavras, mas para a vida, afetando de modo incontornável meus movimentos de leitura e interpretação

Apresentou-me, também, o deleite que há nesse fazer de analista, na brincadeira com as palavras, em escavar os movimentos da memória, perscrutar sentidos outros, mostrando-me que sempre é possível ir mais à frente, vivificando, assim, as palavras de Manoel de Barros, transpondo fronteiras, categorizações e instalando outros gestos de escuta do (en)canto de sabiás...

Para quem tanto fez por mim, só tenho palavras de admiração e agradecimento: pela paciência, por relevar os meus "furos" e confiar no meu trabalho, por sempre ter dedicado com altruísmo o conhecimento, com carinho a companhia e com brilhantismo a orientação deste trabalho 
Ao invés de tomar a palavra, gostaria de ser envolvido por ela e levado bem além de todo o começo possível. Gostaria de perceber que no momento de falar uma voz sem nome me precedia há muito tempo: bastaria então, que eu me encadeasse, prosseguisse a frase, me alojasse, sem ser percebido, em seus interstícios, como se ela me houvesse dado um sinal, mantendo-se, por um instante, suspensa. Não haveria, portanto, começo; e em vez de ser aquele de quem parte o discurso, eu seria antes, ao acaso de seu desenrolar, uma estreita lacuna, o ponto de seu desaparecimento possível. (FOUCAULT, 2005, p. 5-6) 


\section{RESUMO}

Aborda a biblioteca escolar, a partir de uma interface entre a Ciência da Informação, Análise do Discurso de linha francesa e Educação. Busca compreender como a historicidade e a memória discursiva sustentam sentidos sobre o que é esta unidade de informação escolar, observando o litígio entre posições-sujeito e vozes discursivas manifestas em um corpus, composto por recortes de dizeres presentes em blogs, listas de discussão e sites que discursivizam a biblioteca escolar. Objetiva, assim, analisar discursivamente os movimentos do sujeito e dos sentidos nas páginas eletrônicas sobre biblioteca escolar, observando se a rede eletrônica configura-se como o lugar da tão aclamada possibilidade de emergência do sujeito e de dizeres polissêmicos, que façam surgir sentidos além do dominante. Pretende, ainda, refletir sobre a ideologia como mecanismo de naturalização dos sentidos e produção de evidências sobre alguns discursos sobre a biblioteca escolar, e não outros, marcando o que pode ou não ser dito. Para desenvolver tais questões, inicialmente, discorre sobre alguns conceitos fundamentais da Análise do Discurso. Na etapa seguinte, percorre um (ciber)espaço instável, múltiplo e movente, investigando desde as suas condições de produção e as (im)possibilidades de navegação até a maneira como é estruturado e (re)construído, a partir do movimento de sujeitos e sentidos que se constituem ao mesmo tempo, em suas redes. Em seguida, aborda a biblioteca escolar, apresentando os sentidos circulantes em diferentes formações discursivas, a fim de investigar quais retornam, são silenciados ou, ainda, reconstruídos. Apresenta, também, algumas considerações sobre a leitura e pesquisa escolar que, por serem as atividades mais praticadas na biblioteca, tem grande importância na constituição de sentidos sobre ela. Por último, analisa alguns sites de escolas brasileiras, a fim de investigar como elas são discursivizadas, fazendo também algumas considerações sobre as bibliotecas escolares digitais, quais seriam as suas contribuições para novas práticas educativas, indagando se/como é possível sua disseminação no contexto educacional brasileiro. Finalmente, procura analisar discursivamente as representações imaginárias da biblioteca escolar no corpus selecionado. A partir das análises dispostas ao longo do trabalho, infere-se que o ciberespaço heterogêneo e interativo faz falar também o plural, permite os furos nas regiões de sentido estabilizadas pelo retorno da memória, suscitando outras maneiras de enunciar sobre essa instituição, outras margens de sentido.

Palavras-chave: Biblioteca escolar. Discurso. Internet. 


\begin{abstract}
It discusses the school library, from an interface between the Information Science, french Discourse Analysis and Education. It intends to understand how the historicity and discursive memory claim senses about this institution, observing the dispute between subject positions and discursive voices expressed in data, composed by clippings of discourses present in blogs, mailing lists and websites which put in discourse the school library. It aims to analyze, therefore, the movements of the subject and senses in the electronic pages on school libraries, checking if the web configures itself as the place of possibility of emergence of the subject and polysemic words, which raised meanings beyond the dominant. It aims to reflect about the ideology how a mechanism of naturalization of senses and production of evidences about some discourses on school library, and not others, marking which may or not be said. To develop such questions, first It discusses some fundamental concepts of discourse analysis. Then, It tours a (cyber) space unstable, multiple and moving, investigating from their conditions of production and the (im) possibilities of navigating to the way It is structured and (re) constructed from the movement of subjects and senses that constitute themselves in the same time on web. Then, It abroaches school library showing the senses that go around different discursive formations in order to investigate which of them returns, is silenced or rebuilt. It also presents some considerations about reading and scholar research which, being the most practiced activities in the library, they have great importance in the constitution of senses on it. Finally, It analyzes some sites of brazilian schools in order to investigate how they are put in discourse and It also makes some considerations about the digital school library, what are their contributions to educational practices, questioning if/how its possible its dissemination in the brazilian educational context. Lastly, It analyzes the imaginary representations of the school library in data. From the analysis made during this work, It's possible to say that the interactive and heterogeneous cyberspace allows the ruptures in the regions of sense stabilized by the return of memory, prompting other ways of stating on this institution, other margins of sense.
\end{abstract}

Keywords: School library. Discourse. Internet. 


\section{LISTA DE ILUSTRAÇÕES}

Figura 1- KUSH, Vladimir. Bound for Distant Shores. Disponível em:

$<$ http://www.vladimirkush.com/originals.php $>$

Figura 2- ESCHER, Maurits Cornelis. Relativity. Disponível em:

$<$ http://www.mcescher.com/>

Figura 3- ESCHER, Maurits Cornelis. Concentric rinds. Disponível em:

$<$ http://www.mcescher.com/>

Figura 4- SANT'ANNA, Waldomiro. [Biblioteca escolar]. In: ROMÃO, Lucília Maria Sousa (Org.). Sentidos da biblioteca escolar. Ribeirão Preto: Alphabeto, 2008 .

Figura 5- VAN GOGH, Vincent. The mulberry tree. Disponível em:

<http://www.vangoghgallery.com>

Figura 6- KUSH, Vladimir. Current. Disponível em:

$<$ http://www.vladimirkush.com/originals.php>

Figura 7- KUSH, Vladimir. Book of books. Disponível em:

$<$ http://www.vladimirkush.com/originals.php > 


\section{SUMÁRIO}

1 PRIMEIRAS PALAVRAS: SOBRE O MOVIMENTO DE NAVEGAÇÃO.

2 NOS MOVIMENTOS DO DISCURSO: SENTIDOS E SUJEITOS EM

ESPIRAL

2.1 Na tessitura da Análise do Discurso: movimentos de (re)construção.

2.2. Nas trilhas do discurso: palavras em movimento.

2.3 Palavras ao vento, sopros de memória: alguns sentidos de biblioteca escolar

3 NOS LABIRINTOS DA INTERNET: REDES EM MOVIMENTO.

3.1. Do social ao discursivo: considerações sobre as condições de produção de sentidos nas redes labirínticas da Internet.

3.1.1 Das (im)possibilidades de navegação nos info-mares.

3.2 Desenrolando os fios da rede: notas sobre a materialidade do (hiper)texto digital.

3.3 Nas redes da Internet: discursos e sujeitos em movimento.

4 BIBLIOTECA ESCOLAR: SENTIDOS EM MOVIMENTO.

4.1 Memória e atualização de sentidos sobre biblioteca escolar: imbricações.

4.2 Outros sentidos sobre biblioteca escolar: nos meandros do discurso políticocientífico.

4.3 Apontamentos sobre a biblioteca escolar digital: um discurso ainda em construção

5 A BIBLIOTECA ESCOLAR NA REDE ELETRÔNICA: MOVIMENTOS DISCURSIVOS.

5.1 Nas veredas da Internet: rastros de memória e heterogeneidade

5.2 Análise discursiva de dados: vozes que falam da biblioteca escolar.

6. MOVIMENTOS FINAIS: EM BUSCA DE OUTRAS MARGENS.

REFERÊNCIAS 


\section{PRIMEIRAS PALAVRAS: SOBRE O MOVIMENTO DE NAVEGAÇÃO}

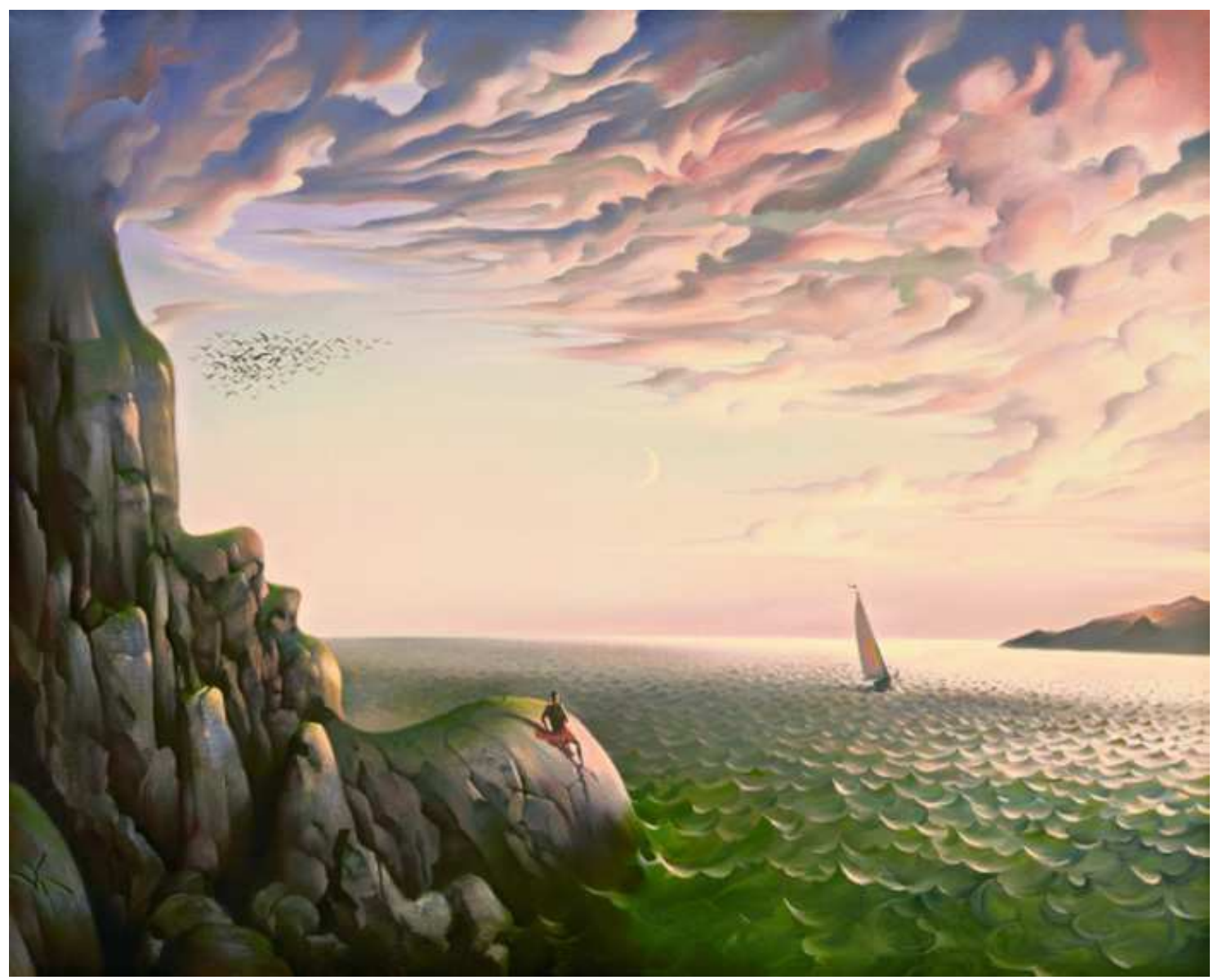

Figura 1. Bound for Distant Shores.

“Navegar é preciso" (PESSOA, 2008, p. 13) 
Presente em minha memória de criança que encontrava na "casa dos livros" um refúgio tranquilo para o despertar da imaginação e, ao mesmo tempo, um espaço de convívio social, de encontro com os amigos e com o conhecimento, a biblioteca fazia parte do meu cotidiano escolar. Em um tempo menos longínquo, no corre-corre das atividades escolares, dos estudos para as provas, para as chamadas orais e da leitura de livros para o vestibular, a biblioteca escolar foi perdendo muito do seu colorido de outrora e fui percebendo que ela não poderia ser apenas a morada de livros. Quanto mais se aproxima das rígidas atividades pedagógicas, frequentemente praticadas nas escolas, mais a biblioteca torna-se um espaço austero e desestimulante, distante da vívida representação infantil repleta do encanto que marca a descoberta das letras e dos sentidos que elas carregam. Desta forma, a biblioteca escolar passa a ser discursivizada e naturalizada como lugar fechado ao múltiplo e limitado em relação aos diversos recursos e atividades que poderia oferecer. Investigar estes e outros sentidos de biblioteca escolar, que foram enrijecidos e estereotipados através da ideologia e da repetição, é o eixo de pesquisa que me trouxe até aqui.

No decorrer da graduação em Ciências da Informação e da Documentação, na Universidade de São Paulo (USP), foram marcantes os muitos encontros e descobertas que preencheram algumas lacunas e desejos de compreensão do mundo, até antes reprimidos e silenciados em um percurso escolar rígido e estático. Entretanto, muito mais importantes foram o surgimento de outros vazios, indagações que aguçaram ainda mais a curiosidade que sempre me acompanhou nas trilhas em direção ao saber, levando-me a desbravar outros mares, em um processo infindável de (re) construção do conhecimento. Em um dos portos de passagem, encontrei a Análise do Discurso e os estudos sobre a mídia e a biblioteca escolar. Ao debruçar-me sobre as pesquisas destes temas, passei a ocupar a posição de pesquisadora e profissional, voltando-me para a construção de sentidos e práticas desenvolvidas nas bibliotecas escolares. Muitos motivos despertaram meu interesse pela biblioteca escolar. Ao longo da graduação, tive contato com este tema, de forma teórica e prática, tanto nas aulas de disciplinas que visavam estudar a biblioteca escolar e as práticas de ensino desenvolvidas nas escolas, assim como, durante as pesquisas realizadas - ao longo de um projeto desenvolvido junto ao Programa Ensinar com Pesquisa, da USP - a respeito das fontes de informação em meio eletrônico sobre este assunto, por meio das quais, tive um amplo contato com a literatura científica e os sentidos veiculados através dela. Quando tive a oportunidade de realizar um estágio em uma biblioteca de uma escola estadual de Ribeirão Preto, pude observar os duelos entre os sentidos circulantes na esfera escolar e aqueles recorrentes no contexto acadêmicocientífico. 
Esses embates suscitaram meu interesse e inquietação em torno da biblioteca escolar, desejo de respostas que foi compartilhado com minha orientadora e encontrou abrigo na teoria discursiva, com a qual trabalho desde 2005. O meu primeiro contato com a Análise do Discurso foi através das disciplinas ministradas pela orientadora, logo no início do curso. A partir deste momento, fui percebendo como o estudo do discurso, da ideologia, do sujeito e da memória constitui-se como uma forma mais prazerosa de lidar com a linguagem, com os efeitos de informação e, também, com a falta, a falha e o equívoco, constitutivos dos sujeitos e dos sentidos. Através de um projeto de Iniciação Científica, financiado pela Fundação de Amparo à Pesquisa do Estado de São Paulo (FAPESP) e desenvolvido em parceria com a orientadora, pude ter um contato maior com a teoria, ao estudar o discurso jornalístico impresso e eletrônico, começando a construir, assim, a base teórica na qual me sustento para desenvolver este trabalho. No ano de 2007, já com um estofo teórico mais consolidado e contando também com a orientação da Prof ${ }^{a}$. Dr ${ }^{a}$. Lucília Maria S. Romão, dediquei-me aos estudos sobre os sentidos atribuídos, pelos sujeitos inseridos nos âmbitos profissional, acadêmico e escolar, à biblioteca escolar, pesquisa que resultou no trabalho de conclusão da graduação. Por meio dele, pude traçar uma interface original e interessante entre a minha formação profissional em Ciências da Informação e da Documentação e a filiação teórica à Análise do Discurso, dialogando também com a Educação, procurando pensar sobre a biblioteca escolar e suas diversas facetas. Agora, unida à minha orientadora em torno dos mesmos interesses, carrego o desejo de navegar pelos mares revoltos do ciberespaço que carregam em suas ondas, em suas redes, múltiplos sentidos de biblioteca escolar, buscando continuar a trajetória percorrida ao longo dos últimos anos.

Tendo como objeto de pesquisa os discursos sobre a biblioteca escolar materializados nas redes da Internet, buscamos, à luz dos conceitos da Análise do Discurso, compreender como a historicidade e a memória discursiva sustentam sentidos sobre o que é esta unidade de informação escolar, observando o litígio entre posições-sujeito e vozes discursivas manifestas no nosso corpus, composto por recortes de dizeres presentes em blogs, grupos de discussão e portais eletrônicos que discursivizam a biblioteca escolar. Objetivamos, assim, analisar discursivamente os movimentos do sujeito e dos sentidos nas páginas eletrônicas sobre biblioteca escolar, observando se a rede eletrônica configura-se como o lugar da tão aclamada possibilidade de emergência do sujeito e de dizeres polissêmicos, que façam surgir sentidos além do dominante. Pretendemos, ainda, refletir sobre a ideologia como mecanismo de naturalização dos sentidos e produção de evidências sobre alguns discursos sobre a biblioteca escolar, e não outros, marcando o que pode ou não ser dito. 
Essa pesquisa ganha relevância na medida em que a rede eletrônica configura-se, apesar dos altos níveis de exclusão digital, como uma importante, como a denominada ferramenta de contato com a informação, conhecimento, entretenimento, etc. Instalando novas formas de significação, o ciberespaço abrange, cada vez mais, arquivos discursivos sobre biblioteca escolar, o que nos leva a indagar se tais sentidos constituiriam uma mudança nas representações sobre esta instituição. Buscar compreender o processo de construção de sentidos sobre a biblioteca escolar delineado na rede eletrônica é importante, na medida em que esta é tomada, cada vez mais, como fonte segura e fidedigna da verdade. Além disso, os problemas enfrentados pela biblioteca escolar, o silêncio a que, muitas vezes, ela é submetida, e o pouco reconhecimento da grande importância desta instituição, fazem com que sejam necessários mais estudos que procurem pensá-la criticamente, de uma forma mais polissêmica e dinâmica, fazendo falar efeitos de valorização e incentivando ações que a ressignifiquem no discurso e na sociedade. Por fim, marcamos a importância de que os estudos sobre o discurso sejam aplicados à biblioteca escolar, aproximando diversos campos do saber, em uma articulação que permite outro olhar sobre os processos educacionais realizados na biblioteca escolar.

A partir de agora, içaremos as velas para iniciarmos nosso percurso de navegação pelos info-mares, que nos levará, primeiramente, a apresentarmos, no capítulo dois, os principais conceitos da Análise do Discurso que embasam nosso trabalho, ajudando-nos a investigar a produção de sentidos sobre a biblioteca escolar no meio eletrônico. Em seguida, no capítulo três, exploraremos o efeito de labirinto eletrônico, múltiplo e mais aberto a outros sentidos e sujeitos; o labirinto virtual da Internet, apresentando os limites para essa abertura, as condições de produção de discursos em suas redes, a sua estrutura e a maneira como os sujeitos se movimentam e constituem sentidos neste ambiente virtual. No capítulo seguinte, discorreremos sobre a biblioteca escolar, retomando os sentidos historicamente construídos sobre esta instituição e que retornam, pela memória discursiva, delineando efeitos de restrição, que se entremeiam àqueles suscitados por outra formação discursiva, da qual faz parte os sentidos de valorização da biblioteca escolar, que acabam distanciando-a de suas particularidades e da forma como ela se apresenta no cotidiano das escolas brasileiras, ao inseri-la em um mundo mágico repleto de maravilhas, apontando o que deveria ser e não o que é ou como poderia tornar-se essa biblioteca ideal; ainda neste capítulo, apresentamos alguns relatos que desconstroem essa representação "fantástica" da biblioteca e, ao mesmo tempo, os sentidos negativos que lhe são atribuídos, ao apresentarem algumas iniciativas de sucesso em bibliotecas, que driblaram as dificuldades encontradas, levando-nos a pensar que é 
possível enfrentarmos as dificuldades e constituirmos bibliotecas escolares mais dinâmicas, desejáveis e abertas ao múltiplo, delineando assim uma outra forma de discursivizá-las nas redes da Internet; para finalizar, mostramos a representação da biblioteca em alguns sites de escolas brasileiras, para, em seguida, apresentarmos a biblioteca escolar digital, indagando se é possível, diante da falta de bibliotecas escolares, que elas se estruturem nas redes da Internet.

Apresentaremos, no capítulo cinco, a análise do nosso corpus, no qual buscaremos investigar a construção de sentidos sobre a biblioteca, nas redes da Internet, a partir da retomada de sentidos historicamente produzidos para significá-la e, também, da emergência de outros que as ressignificam, levando-nos a tecer algumas considerações, apresentadas no capítulo seis, que antecede as referências bibliográficas utilizadas neste trabalho e conferem o efeito de fim deste percurso de navegação. 
2 NOS MOVIMENTOS DO DISCURSO: SENTIDOS E SUJEITOS EM ESPIRAL

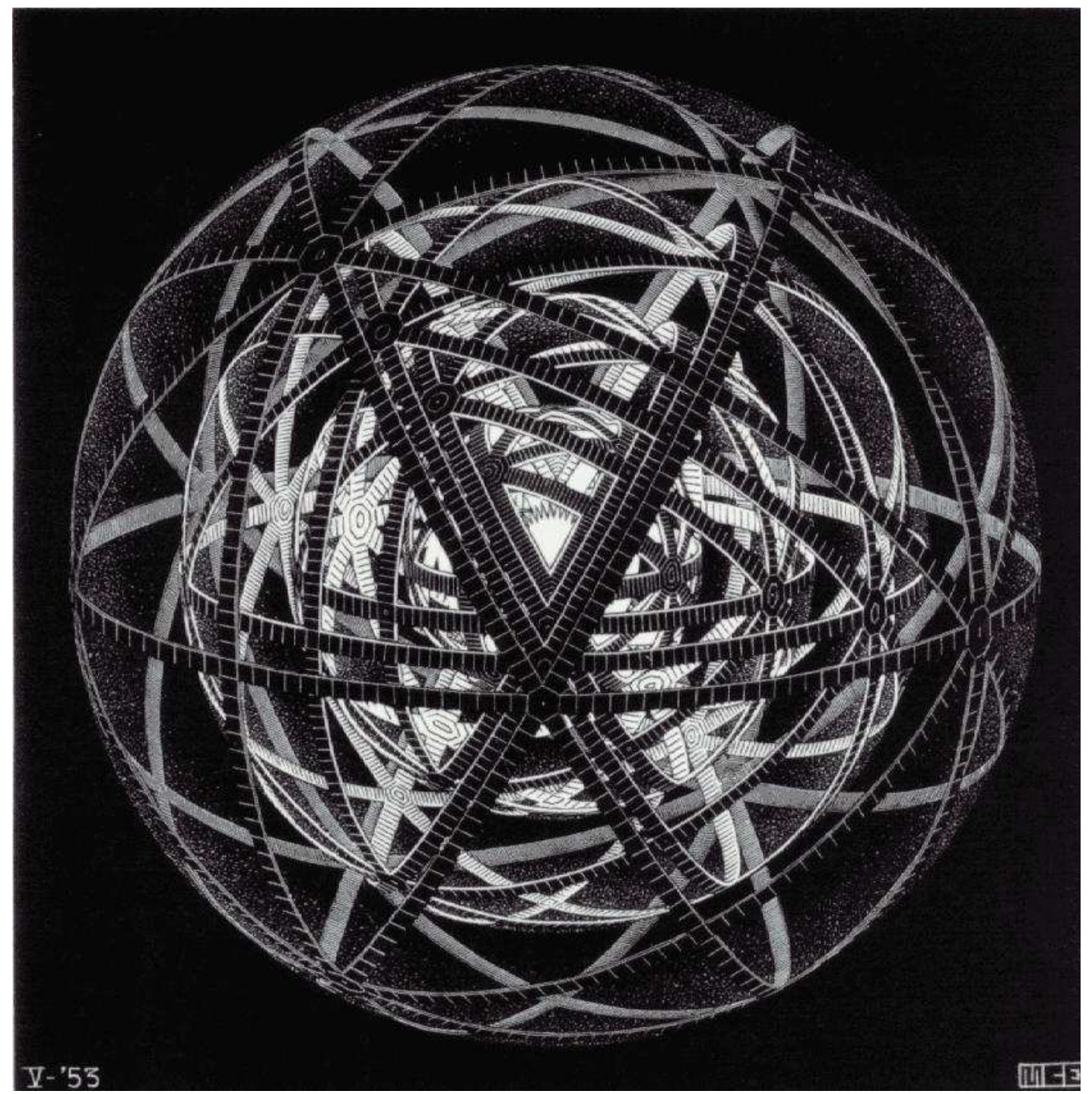

Figura 2. Concentric rinds

O sentido não é capaz de permanecer quieto, fervilha de sentidos segundos, terceiros e quartos, de direções irradiantes que vão se dividindo e subdividindo em ramos e ramilhos, até se perderem de vista. (SARAMAGO, 1997, p. 135) 
$\mathrm{Na}$ perspectiva que adotamos para construir sentidos sobre a biblioteca escolar, trabalhar com o discurso significa procurar "compreender a língua fazendo sentido, enquanto trabalho simbólico, parte do trabalho social geral, constitutivo do homem e da sua história" (ORLANDI, 2003c, p.15), afastando-nos assim de uma postura conteudista (pela qual se acredita que é possível saber o que o autor quis dizer e o qual o significado do texto), na medida em que investigamos "o modo como um objeto simbólico produz sentidos, não a partir de um mero gesto de decodificação, mas como um procedimento que desvenda a historicidade contida na linguagem, em seus mecanismos imaginários" (FERREIRA, 2003, p.202), ou seja, a maneira como a história se inscreve no discurso. Para que possamos investigar os movimentos do sujeito e do discurso sobre a biblioteca escolar, materializados nas redes de sentidos fervilhantes da Internet, mobilizaremos os pressupostos teóricos da Análise do Discurso de linha francesa, especialmente aqueles formulados por Michel Pêcheux, para compreender de que forma eles se constituem, como o processo discursivo é inscrito na língua, e não simplesmente extrair os sentidos do texto. (ORLANDI, 2003a). Ocupamos, para tanto, uma posição intervalar, tal qual a Análise do Discurso, deslocando-nos entre os limites do campo do Discurso, da Biblioteconomia e da Educação, inserindo nossa voz nos interstícios e desvãos da língua, da história e da rede eletrônica.

Ao buscar colocar-se como um objeto-fronteira, a Análise do Discurso trabalha, segundo Ferreira (2000, p. 15), "no limite das grandes divisões disciplinares já institucionalizadas", ocupando uma posição de entremeio que pressupõe a existência de imbricações, deslocamentos e confrontos, que marcam a própria linguagem, sujeita às falhas e rupturas; distanciamo-nos, assim, de uma noção de regularidade, que seria compatível a um mundo lógico e reduzido, no qual "a língua figura como um conjunto homogêneo, cujos elementos estabelecem relações previsíveis e ordenadas." (ORLANDI, 2003b, p. 205). Assim sendo, a constituição da base epistemológica da Análise do Discurso de linha francesa implicou um movimento crítico de intensa (re)elaboração da teoria que, assim como o discurso, não pode ser vista como estável, posto que foi (e ainda é) permeada por diversos embates, correntes teóricas e campos do saber, que amalgamam sentidos alinhados ou divergentes. A teoria do discurso é marcada, assim, pela multiplicidade e, também, heterogeneidade, por uma série de vozes que se compõem nos moldes de um mosaico, em uma (re)combinação caleidoscópica aberta a diferentes perspectivas, ressignificações, a partir do que já está posto. Na próxima seção deste capítulo, seguiremos os rastros que nos levarão a recuperar alguns fios da memória e da história, entretecidos na trama que constituiu a Análise do Discurso de matriz francesa. 


\subsection{Na tessitura da Análise do Discurso: movimentos de (re)construção}

Meu enleio vem de que um tapete é feito de tantos fios que não posso me resignar a seguir um fio só; meu enredo vem de que uma história é feita de muitas histórias. E nem todas posso contar. (LISPECTOR, 1992, p.10).

Antes de apresentarmos alguns importantes conceitos que embasam esse trabalho, julgamos relevante retomar a historicidade que constituiu a própria teoria discursiva, visto que, como já foi dito, “a história está na língua. Esta é uma inscrição incontornável [...] não se pode ficar alheio a tal assertiva, sob pena de nos afastarmos do que toca mais de perto os domínios do discurso" (FERREIRA, 2000, p.27). Recuperaremos, assim, a exterioridade que sustentou essa diversa teia de sentidos composta por muitos fios, entretecidos especialmente por Michel Pêcheux, que foi o principal artesão da teoria. Para podermos compreender o modo como esses fios foram bordados na trama histórica da Análise do Discurso, recorreremos principalmente à Gregolin (2004) e Maldidier (2003), que nos apresentam um mapeamento da complexa conjuntura político-ideológica que propiciou a fremente (re)configuração da teoria do discurso.

Entre reformulações e deslocamentos, os pressupostos teóricos discursivos foram tecidos por meio de relações que gravitaram em torno de três campos do conhecimento: a Linguística, o Marxismo e a Psicanálise (a chamada "Tríplice Aliança"), centrados, respectivamente, em Saussure, Marx e Freud. A releitura desses autores foi o ponto de partida da formulação pecheutiana, de cunho pós-estruturalista e anti-positivista, inaugurando conceitos e estabelecendo seu objeto teórico: o discurso, conforme nos conta Gregolin (2004, p. 25-26):

Da articulação entre propostas de Saussure, Marx e Freud surgirão novos conceitos (sujeito, História, língua) e deles vai derivar o objeto 'discurso', tensionado por uma relação entre esse novo 'estruturalismo' (releitura de Saussure), um novo 'marxismo' (releitura de Marx) e uma nova teoria do sujeito (releitura de Freud) [...] Por operarem esses deslocamentos (nos conceitos de estrutura, de sujeito, de história), esses trabalhos receberam o rótulo de pós-estruturalistas', exatamente para acentuar as diferenças com aquilo que seria um 'estruturalismo formalista'.

É o próprio Pêcheux (2002, p.45) quem destaca o caráter inovador e subversivo dessa sua (re)elaboração teórica, que se constituiu um "desafio intelectual engajando a promessa de uma revolução cultural, que coloca em causa as evidências da ordem humana como estritamente bio-social", as certezas científicas de cunho positivista. Sendo assim, por meio de uma confluência teórica caracterizada pela diversidade, os questionamentos, debates, rupturas 
e reestruturações impulsionaram a construção das bases da teoria do discurso, sem nunca assentá-la em um terreno plano, estabilizado, de certezas inquestionáveis, verdades supremas. Esse caráter volátil, movediço foi flagrado, especialmente, na obra do filósofo Michel Pêcheux que, segundo Maldidier (2003, p.15), "não construiu no firme. Ele é bem o homem dos andaimes, suspensos".

Ao ser gestada na efervescência dos anos 1960, marcados por grandes transformações de ordem político-histórica e cultural, a Análise do Discurso ganhou contornos flexíveis, fronteiras menos rígidas que se abriram às fecundas articulações teóricas com diferentes campos do saber, diversos estudiosos que contribuíram para sua formulação, tanto ao participarem ativamente das discussões fomentadas por Michel Pêcheux e o grupo reunido em torno dele (no qual se destacavam Paul Henry e Michel Plon), quanto ao incitarem tais debates, através de suas obras, promovendo polêmicas que resultaram em instigantes trajetos de aproximações e desencontros, explorados com avidez. São estes caminhos sinuosos que também nos propomos a percorrer na feitura deste trabalho, buscando estabelecer relações entre os estudos do discurso, da rede eletrônica e da biblioteca escolar, instalando a dúvida, sacudindo a poeira do que parece estável e claro.

Ressaltamos que a adoção de uma postura metodológica marcada pela redefinição dos limites e conceitos das ciências sociais implica no estabelecimento de relações nada pacíficas, jogos de força e embates teóricos atravessados por um forte caráter político, que revestiu a Análise do Discurso desde seu início e que marca todo ato de linguagem, visto que, segundo Guimarães (2005, p.8), "enunciar é uma prática política em um sentido muito preciso", devendo ser pensada histórico-ideologicamente. Conforme nos conta Orlandi (2005, p.10), a relação entre o político e o simbólico é central na Análise do Discurso, que se configura como uma teoria que nos permite "compreender como as relações de poder são significadas, são simbolizadas." Assim sendo, os princípios formulados por Michel Pêcheux podem ser mobilizados para analisar a textualização do político e, de forma mais ampla, a política da língua materializada no corpo do texto. No âmbito de nossa pesquisa, levamos em consideração o político, procurando analisar como a rede eletrônica inscreve uma outra maneira de materializar os efeitos de luta, denúncia e reivindicação, a fim de poder saber e dizer sobre a biblioteca escolar, dando voz a sujeitos aos quais foi negada a palavra; ou seja, nós concebemos a materialidade virtual como palco de disputas, um espaço político de dizer, no interior da luta de classes.

Para Michel Pêcheux, um militante do Partido Comunista Francês, a política não se dissociava da teoria, a qual ele considerava um meio de intervir na luta de classes, que é um 
conceito marxista abordado por Louis Althusser: filósofo francês que teve ilustres alunos, como Michel Foucault, Jacques Lacan, além do próprio Michel Pêcheux. O grupo formado por estes teóricos constituía, segundo Gregolin (2004, p. 36), "uma célula muito forte do 'marxismo ocidental', com influência em numerosos discípulos e seguidores, na Itália, na Alemanha, na Espanha e na América Latina." Assim sendo, as questões althusserianas tiveram grande importância para a sustentação político-filosófica de diferentes formulações teóricas, como a da Análise do Discurso, norteando a sua constituição. Como exemplo, podemos apontar a relevância do supracitado conceito de "luta de classes na teoria" que, segundo Pêcheux (1996, p.143), "perpassa o modo de produção como um todo, o que, no campo da ideologia, significa que a luta de classes 'passa' pelo que Althusser chamou de Aparelhos Ideológicos de Estado”, atravessando, assim, a constituição ideológica dos sentidos.

Gregolin (2004) menciona que, a partir das teses althusserianas acerca dos aparelhos ideológicos e o assujeitamento, propôs-se a noção de um sujeito que, atravessado pela ideologia e o inconsciente, não é a fonte de seu dizer. Deste modo, os conceitos (re)formulados por Althusser foram mobilizados, por Pêcheux, para refletir sobre ideologia, sujeito, discurso e sentido, através de uma articulação com a Linguística e a Psicanálise, pela qual se constitui uma teoria não subjetiva do sujeito, ou seja, "em que ele não se apresenta como origem de si” (ORLANDI, 2009, p.3).

Seguindo essa perspectiva, Pêcheux investiu seus esforços na construção de uma teoria materialista do discurso, de base linguística, a partir da leitura althusseriana do marxismo-leninismo, com o objetivo de "desautomatizar a relação com a linguagem" (FERREIRA, 2000, p.39), mudar de terreno, sair do positivismo da estrutura, para dar lugar a uma idéia de articulação entre estrutura e acontecimento. Tal giro teórico-metodológico implica deixar de atentar-se apenas aos "Grandes Textos" para "escutar as vozes cotidianas tomadas no ordinário do sentido, sem correr o risco que aí se aloja- o dos positivismos e filosofias da consciência- em separar o logicamente estabilizado do sujeito a equívoco" (ORLANDI, 2009, p.2). Rompe-se, assim, com a idéia de transparência do sentido que, para a Análise do Discurso, sempre pode tornar-se outro, afetado pela história e o tenso jogo das relações ideológicas de poder entre os sujeitos. Essas considerações nos levam a destacar a grande dimensão dos deslocamentos promovidos pela teoria pecheutiana, cujo caráter conflituoso, como já dissemos, está presente desde o seu início, instalando a dúvida no interior da própria Linguística, questionando os seus postulados. A respeito das relações entre Linguística e Análise do Discurso, Ferreira (2000) aponta que essa se desenvolveu em 
oposição àquela, que se configurava, nos anos 1960, a partir de duas correntes: a gramática gerativa transformacional, fundada por Noam Chomsky, nos Estados Unidos e o estruturalismo que foi elaborado, na França, por Ferdinand Saussure; dentre as duas, é essa última corrente teórica o alvo de nosso interesse, na medida em que buscamos investigar as relações tecidas entre as formulações saussureanas e pecheutianas, as quais são importantes para que possamos compreender os princípios teórico-metodológicos que fundamentam essa pesquisa.

Observamos que, embora a Análise do Discurso tenha ido de encontro ao estruturalismo, apontando seus "furos", reconheceu-se a sua contribuição, pela qual pôde ser instalada uma "ciência do signo", fundada em hipóteses e métodos, conforme é mencionado por Gregolin (2004). Em relação às discordâncias entre essas duas concepções teóricas, podemos apontar que, enquanto Saussure (2003, p. 271) se interessa pelos aspectos estruturais da língua, "considerada em si mesma e por si mesma", Pêcheux (1997) a concebe como materialidade do discurso, que se relaciona com a ideologia e a história, produzindo sentidos. Assim sendo, a teoria do discurso opõe-se à rigidez e à pretensa universalidade presentes na estática proposta saussureana de "procurar as forças que estão em jogo, de modo permanente e universal, em todas as línguas e deduzir as leis gerais às quais se possam referir todos os fenômenos peculiares da história" (SAUSSURE, 2003, p.13).

Ainda a respeito das divergências entre a Linguística e a Análise do Discurso, Ferreira (2000, p. 39-40) faz um paralelo com aquelas existentes, respectivamente, entre produto e processo, em que: "enquanto a primeira trata do produto da constituição dos fenômenos linguísticos, a segunda analisa os mecanismos de funcionamento (os processos) desses fenômenos já constituídos, visando o caráter material dos sentidos”. Por meio dessa perspectiva, podemos inferir que, para a Análise do Discurso, a língua não é estática, acabada, mas está sempre em movimento.

Outro aspecto da teoria saussureana questionado na Análise do Discurso diz respeito à separação entre a língua e a fala, considerando a primeira como "a parte social da linguagem, exterior ao indivíduo, que, por si só, não pode nem criá-la nem modificá-la" (SAUSSURE, 2003, p.22). Essa divisão entre o que é social (língua) e individual (fala), que foi rompida pelo conceito de discurso, vai de encontro à perspectiva pecheutiana, que não postula a existência de filtros que separem elementos internos e externos, visto que a exterioridade é constitutiva da língua, de todo discurso. Assim sendo, consideramos que a Análise do Discurso procurou resgatar e a história e o sujeito que haviam sido apagados da concepção saussureana de língua, instalando uma outra maneira de abordar a questão do sentido, que foi construída 
constantemente ao longo dos anos, pelos teóricos do discurso. Destacamos a existência de três períodos de desenvolvimento da Análise do Discurso, nos quais podemos flagrar a teoria em seus movimentos de (re)elaboração, que revelam:

os embates, as reconstruções, as retificações operadas na constituição do campo teórico da análise do discurso francesa. O solo epistemológico precisou ser revolvido e as mudanças delineiam os debates teóricos e políticos que surgiram de crises que atingiram a reflexão sobre como se dá a articulação entre o discurso, a língua, o sujeito e a História. (GREGOLIN, 2004, p. 60).

O primeiro desses períodos é chamado, por Maldidier (2003), de "tempo das grandes construções", que se estendeu de 1969 até 1975 e iniciou-se com a publicação do livro "Analyse Automatique du Discours", que apresenta as primeiras elaborações acerca do conceito de discurso, visto, de forma ingênua e ainda marcada pelo estruturalismo, como uma "máquina discursiva"- perspectiva esta que foi posteriormente abandonada. Nessa obra, foram lançadas as primeiras questões sobre os textos, a leitura e o sentido, fundamentadas principalmente na teoria saussureana, visto que Marx e Freud foram apenas evocados nesta época em que Michel Pêcheux buscou refletir acerca do tratamento formal da língua, através da Línguística e da Informática. Ainda segundo Maldidier (2003), em um artigo intitulado “A semântica e o corte saussuriano: língua, linguagem, discurso", publicado em 1971 na revista Langages, Michel Pêcheux, Claudine Haroche e Paul Henry fizeram importantes considerações no sentido de problematizar o materialismo histórico, trazendo à tona um novo objeto: o discurso relacionado à ideologia. Entretanto, até então, faltava ainda um ponto decisivo da teoria: a noção de pré-construído, originalmente cunhada por Culioli e reelaborada por Michel Pêcheux, na sua grande obra "Les vérités de la Palice", ou, em português, "Semântica e Discurso: uma crítica à afirmação do óbvio". Nela, Pêcheux (1997) dá um passo à frente, ao articular o conceito de pré-construído ao de interdiscurso, dos quais falaremos na próxima seção. É preciso ressaltarmos o importante desenvolvimento que a teoria discursiva alcançou nesse livro, que apresenta o discurso como a figura central que, segundo Maldidier (2003, p.45), "liga todos os fios: da linguística e da história, do sujeito e da ideologia, da ciência e da política." Podemos destacar ainda, os avanços teóricos correspondentes à reinterpretação da noção foucaultiana de formação discursiva, a partir da teoria althusseriana na qual Michel Pêcheux se ancora, além da elaboração de questões referentes à interpelação ideológica e, também, às condições ideológicas de reprodução e transformação dos modos de produção. 
Observamos que muitas das questões abordadas em "Semântica e Discurso" puderam ser desenvolvidas a partir dos conceitos elaborados em um artigo intitulado "Atualizações e perspectivas a propósito da análise automática do discurso", que foi publicado (meses antes do livro) no número 37 da revista Langages e demonstrou um grande amadurecimento teórico, pelo qual Michel Pêcheux delineou:

o campo teórico, o 'quadro epistemológico' do empreendimento que articula três regiões de conhecimento científicas: - o materialismo histórico como teoria das formações sociais e de suas transformações, aí compreendida a teoria das ideologias; -A linguística como teoria ao mesmo tempo dos mecanismos sintáticos e dos processos de enunciação; - A teoria do discurso como teoria da determinação dos processos semânticos. Intervém uma quarta referência de 'uma teoria da subjetividade (de natureza psicanalítica). É apontado o que vai estar no centro da proposta: a questão da leitura, na sua ligação com a do sujeito. (MALDIDIER, 2003, p. 38)

Nessa conjuntura teórica, Pêcheux pôde desenvolver conceitos fundamentais de sua teoria, como os dois esquecimentos do sujeito, apresentando, assim, a relação estabelecida entre a enunciação e o imaginário, sobre a qual falaremos oportunamente. Após terem sido lançadas as bases de uma teoria materialista do discurso, que se contrapõe à ilusão da transparência do sentido, a Análise do Discurso entrou em uma segunda época marcada por tentativas e reelaborações que, conforme Maldidier (2003), durou até o início de 1980, quando foi realizado, em Nanterre, o Colóquio "Materialidades discursivas", iniciando, assim, uma nova etapa teórica. Nessa segunda fase, a interlocução com os estudos de Michel Plon e Paul Henry contribuiu para os novos rumos tomados pela teoria, que foram afetados por um contexto marcado pelas críticas ao marxismo, as quais encrudesceram nos anos de 1978 e 1979.

Segundo Gregolin (2004), as críticas que Michel Pêcheux teceu em relação à sua "análise automática" levaram à inserção da teoria do discurso nesse novo contexto, marcado por uma revisão de conceitos, pela qual foi posta em cheque a homogeneização advinda das posições radicais assumidas pela teoria althusseriana. Nesse período fecundo de refinamento da teoria, foi problematizada a questão da heterogeneidade, em contraponto ao "primado do mesmo sobre o Outro", abrindo-se espaço para a reformulação dessa concepção- como a que foi realizada por Jacqueline Authier-Revuz, alguns anos depois-, para os questionamentos acerca do destaque até então conferido à paráfrase, ao repetível. Essa ampliação do horizonte teórico da Análise do Discurso também pôde ser observada no abandono da concepção de formação discursiva como um bloco homogêneo, na crença de que os aparelhos ideológicos transformam e não apenas reproduzem as relações de produção, como foi proposto por 
Pêcheux no texto "Remontemos de Foucault a Spinosa", que foi apresentado em um simpósio mexicano, em 1977. Recorrendo à Psicanálise, Michel Pêcheux incorporou à teoria a possibilidade de que os sujeitos resistam, na medida em que propôs, no texto "Só há causa do que falha" (escrito em 1978), que "apreender até seu limite máximo a interpelação ideológica como ritual supõe reconhecer que não há ritual sem falhas" (PÊCHEUX, 1997, p.300-301). Deste modo, critica-se a concepção, presente em "Semântica e Discurso", de um assujeitamento radical, de um "sujeito-pleno", ao mesmo tempo em que se considera a possibilidade do acontecimento, e não apenas da estrutura:

Todo discurso marca a possibilidade de uma desestruturação-reestruturação dessas redes e trajetos: todo discurso é o índice potencial de uma agitação nas filiações sócio-históricas de identificação, na medida em que ele constitui ao mesmo tempo um efeito dessas filiações e um trabalho (mais ou menos consciente, deliberado, construído ou não, mas de todo modo atravessado pelas determinações inconscientes) de deslocamento no seu espaço. (PÊCHEUX, 2002, p.56)

Assim sendo, após esses deslocamentos teóricos, flagramos uma "inversão" da tese da interpelação ideológica, pela qual, segundo Maldidier (2003, p.70), “não é mais no sucesso da interpelação, mas nos traços de seu obstáculo, que se toca o sujeito.” De 1980 a 1983, período nomeado de "desconstrução domesticada", a crise do marxismo acentuou-se, levando Michel Pêcheux a afastar-se ainda mais de suas bases, à medida que ele se aproximava de outros autores e correntes, como por exemplo, a Nova História e as concepções foucaultianas e bakhtinianas. Abriu-se espaço para outras materialidades e os discursos ordinários, para se pensar o arquivo, as rupturas no fio do discurso e o aparecimento de um discurso outro. Nesta perspectiva, também foi abordada, com destaque, a questão da leitura, através da crítica a um automatismo que impede a interpretação. Em seu texto, "Ler o arquivo hoje", Michel Pêcheux apontou a existência de uma "divisão do trabalho da leitura", pela qual a interpretação não estaria disponível para todos. (MALDIDIER, 2003; GREGOLIN, 2004).

Após 1983, ano do falecimento de Michel Pêcheux, "os confrontos entre tendências da análise de discurso francesa não estão mais na moda. Na mexida teórica geral, o campo próprio à linguística está profundamente confuso." (MALDIDIER, 2003, p.78), interrompendo-se, assim, esse intenso movimento de reformulação da teoria pecheutiana. A partir daí, flagrou-se um "desvio de rumos", uma banalização de conceitos, que "deixaram de fora as problematizações da complexa relação entre o sujeito, o discurso e a ideologia." (GREGOLIN, 2004, p.185). Observamos que, atualmente, muitos teóricos, tais como Denise 
Maldidier e Jean-Jacques Courtine, esforçam-se para ir de encontro a esse retrocesso da Análise do Discurso, buscando retomar os conceitos formulados pelos seus fundadores.

É importante ressaltarmos que, no Brasil, a teoria do discurso foi introduzida apenas nos anos 1970, ou seja, quando estava já em um efervescente processo de reelaboração na França. Essa defasagem no tempo, aliada às diferenças de espaço e concepção teórica, resultou, segundo Gregolin (2004), em uma outra maneira de se recepcionar a Análise do Discurso, que privilegia, muitas vezes, as primeiras formulações peuchetianas, fortemente marcadas pelas teses althusserianas, apagando-se, assim, a polêmica que transpassou, de forma tão particular, a teoria do discurso. Entretanto, destaca-se também no Brasil um movimento em direção às origens francesas da Análise do Discurso, procurando contornar esses desvios de rota. A seguir, nós buscaremos também percorrer os caminhos que possam nos levar aos conceitos fundamentais da Análise do Discurso, propostos por seus artesãos e por teóricos que neles se apóiam para fazer avançar a teoria.

\subsection{Nas trilhas do discurso: palavras em movimento}

Ai, palavras, ai, palavras, que estranha potência, a vossa!/ Ai, palavras, ai, palavras, sois de vento, ides no vento/ no vento que não retorna, e, em tão rápida existência/ tudo se forma e transforma! (MEIRELES, 1979, p.28)

Objeto teórico da formulação pecheutiana, o discurso é visto como um lugar de reflexão e interpretação, que nos instiga a investigar como se dão as imbricações de sentidos e sujeitos em sua materialidade, como os discursos sobre a biblioteca escolar se (re)constituem nas instáveis redes da Internet. Deste modo, falar em discurso nos leva a pensar em movimento, a observar o homem falando, conforme nos conta Orlandi (2003c). Assim como a Internet, o discurso é um espaço movediço que está sujeito a transgressões e deslocamentos, afastando-se de concepções que o associam ao discurso empírico enunciado por um indivíduo, à noção de fala, do esquema tradicional da comunicação, em que alguém enuncia, sobre algo e em algum código, para um receptor que deve decodificar a mensagem; do mesmo modo, também não diz respeito ao texto no qual está encapsulado um conteúdo fixo, mas a "um verdadeiro nó, lugar teórico onde se intrincam questões sobre a língua, a história, o sujeito" (MALDIDIER, 2003, p.15). Por essa perspectiva, o discurso é concebido como linguagem em interação, como efeitos de sentido entre sujeitos simbólicos, afetados pela memória discursiva e a conjuntura na qual se inserem. 
Observamos, na ordem da língua, que as relações de mediação entre os sujeitos e a realidade natural e social são suscetíveis a tensões e conflitos, visto que, como já adiantamos, enunciar é uma prática política, ou seja, "tomar a palavra é um ato social com todas as suas implicações: conflitos, reconhecimentos, relações de poder, constituição de identidade, etc [...] pois todo falante ocupa um lugar na sociedade, e isso faz parte da significação" (ORLANDI, 2000, p.17). Ressaltarmos, assim, os embates promovidos pelas disputas por espaços de dizer, mecanismo este que rege o discurso o qual, nesta ótica, "não é simplesmente aquilo que traduz as lutas ou os sistemas de dominação, mas aquilo por que, pelo que se luta, o poder do qual nos queremos apoderar" (FOUCAULT, 2005, p.10). É preciso reconhecer que essas relações de força de que falamos são materializadas na ordem da língua pelo viés da ideologia, perpassando a constituição dos sentidos e levando-nos a apontar que "todo processo discursivo se inscreve numa relação ideológica de classes” (PÊCHEUX, 1997, p. 92), ou seja, é a ideologia que estabelece a construção de sentidos, que não estão colados às palavras.

Distante da perspectiva marxista, que considera a ideologia uma ocultação da realidade, e de outras que a associam ao espírito de um tempo ou a um conjunto de idéias, a teoria pecheutiana a concebe como prática, que existe pelo/para o sujeito, fazendo com que "uma palavra ou um enunciado queiram dizer o que realmente dizem" (PÊCHEUX, 1997, p.160), ou, em outros termos, é um sistema de evidências que naturaliza o sentido, visto pelo sujeito, como o único possível. Assim sendo, é a ideologia que fornece as evidências pelas quais, através da ilusão de transparência da linguagem, "todo mundo sabe", por exemplo, o que é uma biblioteca escolar, suas características, funções, etc. Isso nos leva a apontar que:

o sentido de uma palavra, de uma expressão, de uma proposição, etc., não existe 'em si mesmo' (isto é, em sua relação transparente com a literalidade do significante), mas, ao contrário, é determinado pelas posições ideológicas que estão em jogo no processo sócio-histórico no qual as palavras, as expressões e proposições são produzidas. (PÊCHEUX, 1997, p. 160)

Por conseguinte, é através da noção de ideologia que podemos desconstruir a crença na literalidade do sentido, pois este sempre pode tornar-se outro, ao ser afetado também pela exterioridade, pelas condições de produção de todo dizer, conforme explica Orlandi (2003a, p. 83):

O contexto histórico-social, a situação, os interlocutores - isto a que chamamos tecnicamente de condições de produção- constituem a instância verbal produzida, ou seja, o discurso. Portanto, o discurso não é fechado em si mesmo e nem é do domínio exclusivo do locutor: aquilo que se diz significa em relação ao que não se diz, ao lugar social do qual se diz, para quem se diz, em relação a outros discursos, etc. 
Essas condições de produção do discurso, marcadas pelas disputas de interesses e as tensões decorrentes da manutenção ou ruptura com o poder, podem ser pensadas a partir de duas perspectivas que se completam:

em seu sentido estrito e em sentido lato. Em sentido estrito ela compreende as circunstâncias da enunciação, o aqui e o agora do dizer, o contexto imediato. No sentido lato, a situação compreende o contexto sócio-histórico, ideológico, mais amplo. Se separamos contexto imediato e contexto em sentido amplo é para fins de explicação, na prática não podemos dissociar um do outro, ou seja, em toda situação de linguagem, esses contextos funcionam conjuntamente. (ORLANDI, 2006a, p.15).

Nas situações de enunciação, as condições de produção atuam fazendo com que, dentre todos os sentidos possíveis, alguns sejam dominantes enquanto outros permaneçam silenciados, o que nos leva a considerar a opacidade como constitutiva do discurso, na medida em que temos uma concepção de língua que vai de encontro à crença na existência de uma relação termo a termo entre as palavras e as coisas, que se pretende isenta de contradição, ao buscar construir um mundo semanticamente normal, onde haja correspondência entre as estruturas e suas interpretações; distanciamo-nos, assim, de uma perspectiva que desconsidera a historicidade e o tenso jogo das relações ideológicas de poder entre os sujeitos. É mister dizermos que tais relações se materializam por meio das formações ideológicas, pois, de acordo com Pêcheux (1996, p.145), "a instância ideológica, em sua materialidade concreta, existe sob a forma de 'formações ideológicas' (referidas aos Aparelhos Ideológicos de Estado), que tem um caráter regional e envolvem posições de classes" em confronto.

É oportuno apontarmos que, a partir da ótica althusseriana, os aparelhos ideológicos (dentre os quais podemos citar a escola, a família, a igreja, os partidos políticos, a mídia, etc.) constituem, para a Análise do Discurso de linha pecheutiana, o palco em que ocorre a luta de classes- que perpassa o modo de produção como um todo- e as condições ideológicas de transformação das relações de produção, já que esses aparelhos não são "puros instrumentos da classe dominante, máquinas ideológicas que reproduzem pura e simplesmente as relações de produção existentes" (PÊCHEUX, 1997, p.145), havendo espaço, também, para a contradição, que confere um caráter desigual ao conjunto das formações ideológicas, o qual, por sua vez, é representado, no discurso, pelas chamadas formações discursivas.

De grande importância para a teoria do discurso e também para o nosso trabalho, a noção de formação discursiva, segundo Gregolin (2004), foi cunhada por Michel Foucault (na obra "A arqueologia do saber") e reinterpretado por Michel Pêcheux, sob a forte influência das idéias althusserianas, que leva em conta a ideologia e a luta de classes, produzindo efeitos 
teóricos e políticos. Sendo assim, para Pêcheux (1997, p.160), a noção de formação discursiva diz respeito a:

aquilo que, numa formação ideológica dada, isto é, a partir de uma posição dada numa conjuntura dada, determinada pelo estado da luta de classes, determina o que pode e deve ser dito [...] Isso equivale a dizer que as palavras, proposições, etc., recebem seu sentido da formação discursiva na qual são produzidas.

Compreendemos, assim, que a formação discursiva é a "matriz" dos sentidos, que podem ser repetidos ou deslocados, dependendo de como se dá a articulação entre língua e ideologia, já que "os sentidos são sempre determinados ideologicamente. Não há sentido que não o seja." (ORLANDI, 2003c, p.43). Em outros termos, isso significa que "as palavras, expressões, proposições, etc., mudam de sentido segundo as posições sustentadas por aqueles que as empregam, o que quer dizer que elas adquirem seu sentido em referência a essas posições, isto é, em referência às formações ideológicas [...] nas quais essas posições se inscrevem". (PÊCHEUX, 1997, p.160). Essa injunção ideológica do dizer nos leva a apontar que os sentidos não estão prontos e nem são dados à priori, pois, na ciranda do discurso, sentido e sujeitos se constituem ao mesmo tempo, de formas variáveis e imprevisíveis:

o sentido não está (alocado) em lugar nenhum, mas se produz nas relações: dos sujeitos, dos sentidos, e isso só é possível, já que sujeito e sentido se constituem mutuamente, pela sua inscrição no jogo das múltiplas formações discursivas (que constituem as distintas regiões do dizível para os sujeitos). (ORLANDI, 1997, p.20)

Observamos, ainda, que a possibilidade de deslocamento dos sentidos nos autoriza a pensar que as formações discursivas não são estanques, não constituem um bloco homogêneo referente a uma ideologia dominante, com fronteiras rígidas, posto que, como vimos, não há apenas espaço para a reprodução dos sentidos, mas também para a sua transformação, para a ruptura e a possibilidade de outros lugares para o sujeito enunciar e produzir seu discurso, a partir de diferentes formações discursivas que se interpenetram. E é justamente através da ideologia e da filiação a uma formação discursiva, que se constituem os sujeitos, conforme é explicado por Pêcheux (1997, p.161): “os indivíduos são ‘interpelados’ em sujeitos-falantes (em sujeitos de seu discurso) pelas formações discursivas que representam 'na linguagem' as formações ideológicas que lhes são correspondentes." Deste modo, a interpelação é realizada a partir de um processo ideológico de identificação do sujeito com sentidos considerados por ele como naturais, ou seja, é o complexo das formações ideológicas que "fornece 'a cada 
sujeito' sua 'realidade' enquanto sistema de evidências e de significações percebidas-aceitasexperimentadas." (PÊCHEUX, 1997, p.162).

Posto isto, temos que, através do mecanismo ideológico do assujeitamento, o sujeito é levado a ocupar seu lugar e a enunciar a partir dele, pensando ser o dono do que diz, visto que ele se esquece de que é assujeitado. Ignorando a opacidade, a falta e o inconsciente que lhe constituem, o sujeito acredita ser a origem dos sentidos, como se as palavras brotassem nele; essa ilusão, necessária para que o sujeito possa enunciar, foi chamada, por Pêcheux (1997, p.173), de esquecimento número um, referindo-se ao fato de que "o sujeito-falante não pode, por definição, se encontrar no exterior da formação discursiva que o domina", devendo, assim, filiar-se a ela para enunciar e (se) significar. A respeito desse processo de constituição de sujeitos e sentidos, devemos ressaltar o caráter particular que o determina, visto que o “assujeitamento não se dá da mesma maneira para cada falante da língua" (TFOUNI; PANTONI, 2005, p. 3), ou seja, não é possível estabelecer regras gerais, padrões rígidos, nem muito menos medir ou governar a produção do discurso; impossibilidade esta que nos leva a apontar que a completude e objetividade são, juntamente com os esquecimentos do sujeito, apenas ilusões necessárias para que ele possa enunciar, sem se dar conta do quão falho e lacunar é o ato de dizer.

Alinhado ao primeiro esquecimento, promovido pelo inconsciente, temos o de número dois, que é da ordem da enunciação e leva o sujeito a confiar na existência de uma relação direta entre o seu pensamento e a sua palavra, pela qual se apagam outras formas de dizer. Essa ilusão faz com o que o sujeito acredite que aquilo que enuncia só pode ser dito da maneira como ele o faz, pensando controlar o que diz, quando “'seleciona' no interior da formação discursiva que o domina, isto é, no sistema de enunciados, formas e sequências que nela se encontram em relação de paráfrase- um enunciado, forma ou sequência, e não um outro" (PÊCHEUX, 1997, p.173). Como já sabemos, essa "seleção" do discurso não é realizada conscientemente pelo sujeito, visto que ocorre no momento de sua interpelação pela ideologia, ou seja, de sua própria constituição, afetada pela exterioridade e pela memória discursiva.

Posto isto, frisamos que, pelas vias do assujeitamento/esquecimento, alguns sentidos, de tão repetidos, são vistos, pelos sujeitos, como óbvios, os únicos possíveis de serem enunciados, enquanto outros são apagados. Entretanto, mesmo estando legitimados, os sentidos podem, como já foi dito, ser fraturados, moverem-se, por meio das tensões que envolvem as formações ideológicas, a história e as relações de poder, o que nos leva a afirmar, assim como Maldidier (2003), que a ideologia, da mesma forma que a língua, não é 
um sistema hermético, mas "esburacado", repleto de lacunas. Admite-se, então, que o assujeitamento não é radical, ou seja, que ele é passível de falhas, abrindo um espaço para o sujeito resistir, já que "não há identificação plenamente bem sucedida". (PÊCHEUX, 2002, p.56).

Inferimos que, assim como o discurso e a ideologia, o sujeito também é passível de falhas e equívocos, sendo marcado pelos "furos" em seus dizeres. Nesta perspectiva, o sujeito é entendido, por nós, não como "entidade homogênea, exterior à linguagem" (AUTHIERREVUZ, 2004, p.63), nem como o sujeito cartesiano, um indivíduo totalmente consciente, ser empírico, "de carne e osso", que pode ser quantificado e classificado, mas como sujeito do discurso que, segundo Orlandi (2003c, p.20), "funciona pelo inconsciente e pela ideologia". Falamos aqui de um sujeito que, conforme nos diz Ferreira (2003, p.202), não pode ser visto como o "senhor da língua", já que se revela dividido, clivado entre o consciente e o inconsciente, sendo constituído ideologicamente por uma contradição, pela qual "ele está sujeito (à língua) para ser sujeito de (o que diz)” (ORLANDI, 2006a, p.19).

Ao ocuparmos este lugar teórico, afastamo-nos de um olhar positivista, que insere o sujeito em um mundo lógico de certezas a serem apreendidas, concebendo-o como um efeito de linguagem, marcado pela possibilidade de ocupar diferentes posições (mas não todas), a partir das quais ele constrói sentidos, afetado pelas condições sócio-históricas e ideológicas. Essas posições, que podem ser assumidas pelo sujeito ao enunciar, são determinadas também pelas formações imaginárias, da ordem do inconsciente; por meio delas é que as imagens dos sujeitos, resultado de projeções, funcionam na linguagem, ou seja, são elas que permitem a passagem de uma situação empírica (lugar do sujeito) para uma posição do sujeito no discurso. Tais projeções, afetadas pela exterioridade, constituem um jogo que regula a troca de palavras, produzindo, também, imagens do objeto discursivo.

Por meio desses jogos imaginários, é possível, por exemplo, que um bibliotecário enuncie a partir do lugar de organizador de acervos, inspetor, educador, aluno, pesquisador, representante de órgão de classe, mediador de leituras, dentre muitos outros possíveis, produzindo diferentes sentidos sobre a biblioteca escolar; assim sendo, no exemplo citado, o que funciona no discurso não é o bibliotecário visto de forma empírica, mas enquanto uma posição discursiva, produzida pelas formações imaginárias. Segundo Orlandi (2003c, p.39), tal jogo imaginário pode ficar ainda mais complexo se incluir a antecipação, pela qual o sujeito tenta antever os sentidos que supostamente seus interlocutores esperam ou gostariam de ouvir, já que: 
todo sujeito tem a capacidade de experimentar, ou melhor, de colocar-se no lugar em que o seu interlocutor 'ouve' suas palavras. Ele antecipa-se assim a seu interlocutor quanto ao sentido que suas palavras produzem. Esse mecanismo regula a argumentação, de tal forma que o sujeito dirá de um modo, ou de outro, segundo o efeito que pensa produzir em seu ouvinte.

Como exemplo do funcionamento desse mecanismo de antecipações, podemos citar as indagações acerca da imagem que o bibliotecário tem da imagem que os alunos fazem dele e da biblioteca escolar, ou ainda, sobre qual seria a imagem que os alunos fazem da imagem que o bibliotecário faz da biblioteca escolar, etc. É importante ressaltarmos, apoiando-nos em Orlandi (2003c), que tais jogos imaginários são sustentados por relações de poder, que regulam a produção de sentidos, a partir de um confronto entre o político e o simbólico. Intervém nesse processo de constituição ideológico-imaginária do discurso, o acesso a um determinado saber sobre, por exemplo, o que é um bibliotecário e uma biblioteca escolar; em outras palavras, trata-se de um discurso prévio, da ordem do repetível, que sustenta as posições que assumimos, enquanto sujeitos do discurso, para produzir sentidos, constituindose a partir da estabilidade, ainda que essa seja fugaz. Sendo assim, é possível observamos, no fio de todo discurso, rastros de dizeres já ditos e esquecidos, que nos permitem historicizar os sentidos, que retornam e se movimentam de maneiras diferentes, sob o signo da exterioridade. Para refletirmos acerca dessa questão, iremos nos valer da teia de sentidos sobre a memória que foi urdida especialmente por Michel Pêcheux, seu exímio artesão, para o qual a memória discursiva é a condição de todo dizer, suportando o funcionamento da linguagem.

Posto isto, não podemos compreender a memória como sendo a lembrança de algo que passou, nem como memória institucionalizada nos arquivos, mas como a "voz sem nome" de que fala Foucault (2005), aquela que transpassa os sujeitos no momento da enunciação. Por conseguinte, temos que é a memória que possibilita as condições de legibilidade do dizer, pois as palavras não se significam por si mesmas, mas sempre pelo movimento construído socialmente a partir da relação delas com o poder. Sendo assim, entendemos que o conceito de memória corresponde às zonas do já-lá que são recortadas pelos sujeitos no momento da constituição do discurso. Recorrendo a Tfouni e Pantoni (2005, p.2), podemos apontar que, ao sinalizarmos a presença de um já-lá em cada processo de significação, estamos nos referindo ao permanente retorno de sentidos "que foram se construindo historicamente a partir da constelação das relações de poder, que podem ser assumidos ou não pelo sujeito, a depender das posições discursivas que este poderá ou não ocupar em função do funcionamento da ideologia"; por conseguinte, temos que são as imbricações entre sujeito, ideologia e memória 
que determinam a produção de sentidos, sustentada por uma exterioridade que lhe é constitutiva.

Investigando mais a fundo a questão da memória discursiva, recuperamos as palavras de Pêcheux (1999, p.52), para o qual ela seria aquilo que "face a um texto que surge como acontecimento a ler, vem restabelecer os 'implícitos' (quer dizer, mais tecnicamente, os préconstruídos, elementos citados e relatados, discursos-transversos, etc) de que sua leitura necessita". Assim sendo, para interpretar os discursos sobre a biblioteca escolar que circulam nas redes da Internet, nós precisamos recorrer aos traços daquilo que já foi dito, em outros contextos sociais, e que pode retornar, ou não, evocando diferentes sentidos que irrompem no enunciado como se já tivessem sido pensados "antes, em outro lugar, independente" (PÊCHEUX, 1997, p.156).

Deparamo-nos, aqui, com uma questão muito cara ao nosso trabalho, que diz respeito à impossibilidade de negarmos a existência de um já-dito, de um "sempre-já-aî" da interpelação ideológica que estabelece a significação; estamos falando do pré-construído, conceito elaborado por Paul Henry, que se refere a "aquilo que todo mundo sabe" e "que remete a uma construção anterior, exterior" (PÊCHEUX, 1997, p.99). Podemos considerar ainda que o pré-construído, ao lado da articulação (referente ao "como dissemos", "como todo mundo sabe" e "como todo mundo pode ver"), é um elemento do interdiscurso, o qual se refere ao conjunto de todos os dizeres já falados e filiados a uma formação discursiva, que estabelece uma relação muito próxima com o funcionamento da memória. Tal correspondência reside na condição da memória atuar como um mecanismo que faz retornar o interdiscurso, materializando-o na língua, o que é confirmado por Agustini (2005, p.3), quando ela diz que a memória constitui-se como um "efeito da presença do interdiscurso (eixo da verticalidade) no acontecimento (eixo da horizontalidade) do dizer". Isso implica considerar que o sujeito, para constituir o fio do seu discurso (ou seja, o intradiscurso, que é um efeito do interdiscurso sobre si mesmo), mobiliza algumas regiões do interdiscurso, alguns sentidos que compõem esse " "todo complexo com dominante' das formações discursivas" (PÊCHEUX, 1997, p.162), fornecendo aos sujeitos a sua "realidade", enquanto um sistema de evidências que, conforme apontamos, faz parecer natural que ele enuncie de uma determinada maneira, silenciando outras. Deste modo, consideramos que não se pode dizer tudo, sendo necessário que se apague, para o sujeito, o funcionamento da memória, pois, se assim não o fosse, ficaríamos impassíveis, petrificados diante do reconhecimento dos estrangeiros postos em discurso por nós, da constatação de que tudo já foi dito. Nas palavras de Borges (2001, p.100), isso significa dizer que "a certeza de que tudo está escrito nos anula ou nos 
fantasmagoriza", ou seja, tal constatação nos privaria da própria condição de sermos sujeitos, atravessados pelo esquecimento e a memória pra poder enunciar.

Posto isto, consideramos que a memória também é constituída pelo esquecimento "que torna possível o diferente, a ruptura, o outro" (ORLANDI, 2003c, p.10), na medida em que apaga a filiação histórica dos sentidos, para que o sujeito possa construir o seu discurso, outros significados a partir do mesmo. Notamos ainda que os sentidos silenciados, nesse processo fundamental para a tomada da palavra, podem, em outras situações de enunciação, entrar na ordem do discurso, ou seja, serem atualizados, estabelecendo diferentes relações de significação. Posto isto, observamos, na esteira de Pêcheux (1999, p.56), que esses jogos entre a memória e a atualização, a repetição e o deslocamento de sentidos mostram-nos que a memória discursiva não pode ser entendida de forma estática, como:

uma esfera plena, cujas bordas seriam transcendentais históricos e cujo conteúdo seria um sentido homogêneo, acumulado ao modo de um reservatório: é necessariamente um espaço móvel de divisões, de disjunções, de deslocamentos e de retomadas, de conflitos e de regularização. Um espaço de desdobramentos, réplicas, polêmicas e contra-discursos.

$\mathrm{Na}$ instabilidade dessas disputas por espaços de (contra-)dizer, podemos ver surgir o novo no interior mesmo do repetível, ou seja, assegura-se a possibilidade de emergência do acontecimento, que "desloca e desregula os implícitos associados ao sistema de regularização anterior" (PÊCHEUX, 1999, p.52), levando-nos a considerar a deriva como constitutiva do discurso, pois:

todo enunciado é intrinsecamente suscetível de tornar-se outro, diferente de si mesmo, se deslocar discursivamente de seu sentido para derivar para um outro (a não ser que a proibição da interpretação própria ao logicamente estável se exerça sobre ele explicitamente). Todo enunciado, toda sequência de enunciados é, pois, linguisticamente descritível como uma série (léxicosintaticamente determinada) de pontos de deriva possíveis, oferecendo lugar a interpretação. É nesse espaço que pretende trabalhar a análise de discurso. (PÊCHEUX, 2002, p. 53)

Deste modo, abrem-se brechas para que os sentidos se movam, sem parada, visto que não estão completamente definidos, sendo atravessados pela falta. A partir dessa concepção, a incompletude- garantida pelo silêncio- é vista como fundamental, pois produz a possibilidade do múltiplo, de subversão do que parece evidente, ou, em outras palavras, da polissemia, que se refere à "força na linguagem que desloca o mesmo, o garantido, o sedimentado." (ORLANDI, 2003a, p.27). Como contraponto, temos a paráfrase, a estabilização dos sentidos, ou seja, o retorno aos mesmos espaços do dizer, produzindo diferentes maneiras de 
cristalização de um discurso. É importante ressaltarmos ainda que, através dos jogos entre a paráfrase e a polissemia- a estrutura e o acontecimento- é que "os sujeitos e sentidos se movimentam, fazem seus percursos, (se) significam" (ORLANDI, 2003c, p.36).

A partir do que foi exposto, podemos situar o sentido em um lugar provisório, que desestabiliza uma concepção estática de língua, rompida pelas múltiplas possibilidades de significação dadas pelos movimentos de um sujeito cujo dizer é atravessado por outros. Ao enveredarmos por essas questões, deparamo-nos com o conceito de heterogeneidade, que foi desenvolvido, pela linguista francesa Jacqueline Authier-Revuz, a partir da noção de polifonia, formulada pelo teórico Mikhail Bakhtin. Ancoradas a esse referencial, consideramos que, na constituição dos seus discursos, os sujeitos são afetados também por outras vozes, por sentidos emprestados de outrem, que nos lembram que as palavras são habitadas por discursos, conforme é explicado por Authier-Revuz (2004, p. 140-141): “sob nossas palavras, 'outras palavras' sempre são ditas; que, atrás da linearidade 'da emissão por una única voz', se faz ouvir uma 'polifonia'; que todo discurso parece se alinhar sobre várias pautas de uma partitura." É ainda a autora que nos propõe que esse atravessamento de vozes no discurso do sujeito pode se manifestar a partir de duas formas, a saber, heterogeneidade constitutiva e heterogeneidade mostrada (marcada ou não). Em relação à primeira, podemos afirmar que ela se refere ao constante retorno do interdiscurso, o Outro ${ }^{1}$ de que fala AuthierRevuz (2004), que é condição essencial de todo ato de enunciação. Paralelamente a ela, temos a heterogeneidade mostrada, que corresponde, segundo a autora, às "formas linguísticas de representação de diferentes modos de negociação do sujeito falante com a heterogeneidade constitutiva do seu discurso" (AUTHIER-REVUZ, 1990, p.26), remetendo-nos explicitamente à presença do outro que atravessa constitutivamente o um e nos lembra que os sentidos não estão prontos. Isso pode ser observado, de forma visivelmente marcada, através do uso de citações, aspas, itálico, depoimentos, discursos direto e indireto, dentre outras "formas marcadas que atribuem ao outro um lugar linguisticamente descritível, claramente delimitado no discurso" (AUTHIER-REVUZ, 2004, p.21). Como exemplo de heterogeneidade mostrada e não marcada- pelas quais se estabelece um efeito de sentido (que não é visível) de um dito articulado a um não-dito-, podemos citar a ironia, a imitação, o discurso indireto livre, metáfora, etc.

\footnotetext{
${ }^{1}$ Apontamos usos distintos para os termos "outro" e "Outro": o primeiro refere-se à "presença de um outro sujeito enunciador exterior trazido para dentro do discurso, identificável, através das formas mostradas de heterogeneidade. O "Outro" se refere ao interdiscurso funcionando como pré-construído" (MITTMANN, 1999, p. 229), que, segundo Authier-Revuz (2004, p. 69), é "uma condição (constitutiva, para que se fale) do discurso de um sujeito falante que não é fonte-primária desse discurso."
} 
Ressaltamos, por fim, a contribuição da noção de heterogeneidade para a discussão de algumas questões de nosso interesse, relacionadas à construção dos discursos sobre a biblioteca escolar materializados na Internet, em cujas teias de sentidos plurais "engendra-se o novelo heterogêneo de sentidos, sujeitos e arquivos, que se justapõem em um patchwork de fundura e largueza imensas, fazendo tagarelar ditos tantos." (ROMÃO, 2006, p. 5-6), a partir da intensa profusão de links e recursos eletrônicos que evidenciam os fios dialógicos constituintes das redes do discurso e da Internet- questões estas que serão explanadas, de forma mais ampla, no próximo capítulo; por ora, apresentaremos, na seção seguinte, algumas considerações acerca de três documentos em meio eletrônico e os sentidos sobre a biblioteca escolar que neles funcionam.

\subsection{Palavras ao vento, sopros de memória: alguns sentidos de biblioteca escolar}

Para los navegantes con ganas de viento, la memoria es un puerto de partida. (GALEANO, 1993, p. 96)

$\mathrm{Na}$ materialidade virtual, as palavras e os sentidos que elas carregam tem exaltado o seu caráter provisório e movediço, suscetível ao movimento de ventos que os levem a lugares outros, mas que são sempre impulsionados por sopros de memória que atravessam todo dizer. Deste modo, a Análise do Discurso nos leva a considerar o interdiscurso, as regiões do já-lá, que ora retornam do mesmo modo, ora irrompem como sentido outro e diverso, constituindo a base dos processos de significação, que são o objeto de nosso interesse, curiosidade e indagações.

Sendo assim, nos documentos oficiais que analisamos em pesquisas anteriores (cf. FERRAREZI; ROMÃO, 2008b), nós pudemos observar um forte caráter parafrástico dos sentidos de biblioteca escolar, pelo qual há uma volta constante aos mesmos espaços de dizer. Dando continuidade a essas investigações, flagramos, no corpus de análise deste trabalho, alguns movimentos de retorno desses mesmos sentidos, materializados agora em três documentos dos Conselhos de Biblioteconomia, a saber, o folheto de uma exposição sobre biblioteca escolar realizada em Brasília (ANEXO 1), o Manifesto em Defesa da Biblioteca Escolar (ANEXO 2), elaborado pelo CFB e os CRB's, e a Carta de Brasília do Conselho Federal e Regionais de Biblioteconomia em defesa da biblioteca escolar (ANEXO 3).

Por essa rede de paráfrases, circulam sentidos dominantes que normatizam o que e como a biblioteca escolar deve ser, ou seja, as recomendações acerca de suas funções, objetivos e funcionamento, que constituem um pré-construído aparentemente óbvio e natural, 
marcando o que pode ser dito sobre a biblioteca escolar, quais aspectos devem ser considerados, deixando latentes uma série de outros discursos que, sob outras condições sócio-histórico-ideológicas, poderiam ser atualizados.

Sendo assim, ao rastreamos as pistas do funcionamento da ideologia e da memória, em um cartaz de divulgação de uma exposição sobre a biblioteca escolar (CONSELHO FEDERAL DE BIBLIOTECONOMIA, 2009), observamos que os sentidos sobre essa instituição desfilam na forma de tópicos onde o sujeito antecipa, tenta antever o que supostamente os sujeitos-leitores aos quais se dirige (por meio das marcas linguísticas "liberte" e "você") gostariam ou precisariam saber sobre o evento que está sendo promovido, discursivizado. Essa maneira de estruturar o discurso, topicalizando-o, indicia uma tentativa ilusória de condensação dos sentidos (tão cara ao discurso publicitário) sobre o objeto discursivo, na qual o sujeito se esquece (lembrando que esse esquecimento é ideológico) de que há sempre algo que escapa e falha na linguagem, não sendo possível o controle dos sentidos. Assim sendo, o que temos é a atualização de alguns sentidos, dados pela memória, que representariam o que, pelo jogo das formações imaginárias, é considerado como o mais importante, digno de ser divulgado, instalando uma maneira de enunciar sobre a biblioteca, que é vista como a única possível.

Investigando a construção desse saber discursivo sobre a biblioteca escolar, pudemos flagrar, nos três documentos analisados aqui, o atravessamento de várias vozes manifestas- no discurso dos órgãos de classe- pela heterogeneidade mostrada e (não-) marcada, que fazem retornar sentidos presentes em documentos oficiais de reconhecidos órgãos internacionais (como a Organização dos Estados Americanos- OEA, International Federation of Library Associations and Institutions- IFLA e United Nations Educational, Scientific and Cultural Organization- UNESCO) e, também, federais brasileiros, como o Ministério da Educação. Inferimos que tais documentos, pelo prestígio que lhe são atribuídos, conferem um efeito de legitimidade e veracidade aos documentos que os retomam, efeito este que é reforçado pelo uso de citações e cifras apresentados como claros e irrefutáveis.

Pela maneira como se faz a costura entre a memória, ideologia e o discurso, no tecido das relações sociais, vemos serem naturalizados os sentidos que atribuem à biblioteca características consideradas ideais, discursivizando-a a partir de sua importância, fazendo ressoar, nas redes da Internet, a primazia desse "mundo de saber", no qual "tudo começa" (CONSELHO FEDERAL DE BIBLIOTECONOMIA, 2009, p.1). Notamos, assim, um funcionamento discursivo pelo qual a biblioteca escolar tem seus horizontes alargados, suas funções dinamizadas e os objetivos diferenciados, indiciando o esforço de inseri-la- pelos 
jogos de formações imaginárias- em outra posição discursiva, ainda que esta não corresponda ao seu lugar social.

Observamos tal movimento de constituição de sentidos, nos documentos dos conselhos de biblioteconomia, nos quais a repetição de alguns verbos materializa efeitos de movimento e dinamicidade, que se distanciam de alguns sentidos comumente empregados pra falar sobre a biblioteca escolar, na medida em que discursivizam as funções a serem desempenhadas por elas. Isso pode ser observado nas seguintes marcas linguísticas: "promove", “influenciar", “incentivar", “viabilizar" "estimula”, “organizar", “trabalhar", "atua", "investirem" e "interagem", que sinalizam uma tentativa de romper com discursos que, historicamente, atribuíram às bibliotecas a exclusiva e estática função de armazenar e conservar acervos. A presença de sentidos mais plurais pode indiciar um desejo de mudança nas práticas realizadas nas bibliotecas escolares, pelo qual se buscaria tecer uma relação com o sujeito-leitor, cativá-lo, atraí-lo e não apenas esperar que ele adentre o portão da biblioteca e percorra as suas estantes

Inseridos nessa região de sentidos, que introduz a biblioteca em uma posição de maior prestígio, visibilidade e atuação, na escola e sociedade (evocando um já-dito presente, especialmente, em documentos oficiais internacionais e em documentos científicos que atribuem o que/como deve ser uma biblioteca escolar ideal), estão os discursos que a associam a um "centro de aprendizagem” com "função pedagógica” (MANIFESTO..., 2009, p.4), pela qual ela deveria atuar em prol da aprendizagem permanente, o estímulo à criatividade, comunicação, cultura, recreação e a formação docente; oferecendo o acesso a diversos recursos que devem estimular a polissemia; assumindo um papel político e estendendo suas ações para a comunidade escolar e externa, a fim de derrubar os muros que, há séculos, separam-na da grande maioria da população, conforme podemos observar nos recortes a seguir:

[...] elemento que forma o indivíduo para aprendizagem permanente; estimula a criatividade, a comunicação, facilita a recreação, apóia os docentes em sua capacitação e lhes oferece informação necessária para tomada de decisão na aula. (CONSELHO FEDERAL DE BIBLIOTECONOMIA, 2009, p.1, grifos nossos)

A biblioteca escolar não somente lida com as demandas do aluno, mas, sobretudo, atua no contexto do projeto político-pedagógico da escola, através do trabalho conjunto com o professor e a gestão escolar. (MANIFESTO..., 2009, p.4, grifos nossos)

Espaço de aquisição e disseminação de cultura e informação (MANIFESTO..., 2009, p.5, grifos nossos). 
[...] ambientes de busca e aprimoramento de conhecimentos. (MANIFESTO..., 2009, p.4, grifos nossos)

Favorecer o acesso a recursos locais, regionais, nacionais e globais e a oportunidade para que os estudantes exponham diferentes idéias, opiniões e experiências. (CONSELHO FEDERAL DE BIBLIOTECONOMIA, 2009, p.2, grifos nossos)

Entre as ações consideradas como as mais importantes para serem desempenhadas nas bibliotecas, destaca-se a promoção de atividades e serviços, cujo enfoque é dado especialmente à leitura e a pesquisa, constituindo uma maneira de falar sobre a biblioteca, na qual estaria implícita a necessidade de um movimento de leituras para que a biblioteca escolar se signifique:

Promover a leitura, recursos e serviços da biblioteca a toda a comunidade escolar e à comunidade externa (CONSELHO FEDERAL DE BIBLIOTECONOMIA, 2009, p.2, grifos nossos)

[...] permite o fomento da leitura [...] uma ação em prol da leitura e do incentivo à criação do gosto e hábito de ler (CONSELHO FEDERAL DE BIBLIOTECONOMIA, 2009, p.1, grifos nossos)

Espaço para o desenvolvimento da pesquisa escolar e do trabalho intelectual [...] (CONSELHO FEDERAL DE BIBLIOTECONOMIA, 2009, p.1, grifos nossos)

Considerando que uma das atividades a ser desenvolvida pela biblioteca escolar é o incentivo à leitura [...]. (MANIFESTO..., 2009, p.4, grifos nossos)

[...] importância da biblioteca na prática da leitura e escrita [...] um espaço apto a influenciar e incentivar a prática da leitura e escrita [..] espaço de excelência na aquisição de leitura e escrita (CARTA..., 2007, p.1, grifos nossos)

Frisamos que, apesar de fazerem circular sentidos que sustentam um dizer sobre a importância da realização de atividades de natureza literária e cultural, nenhum dos três documentos analisados apontam, de maneira efetiva, como a biblioteca escolar pode alcançar as metas propostas, exercer tais atividades às quais é chamada. Tal silenciamento de sentidos, que procurem ir além da repetição de discursos que ponham em circulação sentidos sobre o "que" e não o "como" fazer, constitui um funcionamento discursivo que observamos ao longo dos últimos três anos em que nos dedicamos a investigar a biblioteca escolar, lembrando-nos de que as palavras transpiram sentidos que já foram falados em outros lugares, de que diversas vozes atravessam as palavras que mobilizamos para construir o nosso discurso. 
Observamos que, na heterogênea teia digital, os sentidos apresentados até aqui se amarram a outros, que vão de encontro a eles, instalando a contradição, pela qual se discursiviza a biblioteca escolar como uma simples coadjuvante, mero "instrumento", "suporte", para realizar a "missão da escola". Pelo jogo das formações imaginárias, a biblioteca escolar é enunciada a partir do seu caráter funcional, que conferiria ao sujeito-aluno a possibilidade de "desempenhar seus papéis sociais", ir ao encontro do que espera dele, ou seja, constituir-se como "cidadão" com "consciência cultural e social", em uma sociedade pretensamente democrática, atribuindo-lhe, assim, direitos, como liberdade e acesso às informações, na medida em que normatizam qual seu dever perante a sociedade. Para tanto, retornam, através da heterogeneidade mostrada não marcada, sentidos circulantes nos documentos internacionais que atestam os direitos dos cidadãos, por meio dos quais, a educação é vista como direito de todos (exaltação dos valores democráticos), condição para a cidadania, civilização e cultura. Vejamos alguns recortes em que tais sentidos aparecem:

Espaço para o desenvolvimento da pesquisa escolar e do trabalho intelectual que proporcionarão ao educando meios para desempenhar seus papéis sociais. [...] Ação cultural com vista a favorecer o entendimento da identidade do cidadão no espaço onde vive. (CONSELHO FEDERAL DE BIBLIOTECONOMIA, 2009, p.1, grifos nossos)

Organizar atividades que estimulem a sensibilidade e a consciência cultural e social [...] Trabalhar com estudantes, professores, administradores e pais para realizar a missão da escola. [...] Proclamar a idéia de que a liberdade de expressão e o acesso à informação são essenciais à efetiva e responsável cidadania e participação na democracia (CONSELHO FEDERAL DE BIBLIOTECONOMIA, 2009, p.2, grifos nossos)

[...] proporcionarão ao educando meios para melhor desempenhar seus papéis sociais [...] favorecer o entendimento da identidade do cidadão. (MANIFESTO..., 2009, p.4, grifos nossos)

A qualidade da educação acha-se intimamente ligada à oferta, pela escola, de meios, instrumentos, equipamentos e suporte para que o educando integre-se à cultura, assimile, processe e produza enquanto sujeito do processo civilizatório, sujeito da construção da cidadania. Este (sic) o sentido das disposições do art.205 da carta magna, garantidores da universalização da (CARTA..., 2007, p.1, grifos nossos)

Através do que foi exposto, inferimos que, ao enunciarem a partir desta perspectiva sobre as bibliotecas escolares- que restringe tanto as funções atribuídas às mesmas quanto os movimentos dos sujeitos-leitores, aos quais é imputado (ilusoriamente) um caráter homogêneo, como se fosse possível que todo sujeito tecesse sentidos da mesma maneira, possuindo as exatas e tão requeridas habilidades, "competências" em informação, leitura e 
escrita (MANIFESTO..., 2009; CARTA..., 2007) -, temos o pressuposto de que apenas os saberes autorizados no âmbito escolar são legítimos, adequados, úteis e que o aluno precisa sujeitar-se a eles para ser um "cidadão civilizado", isto é, para que não seja como aqueles que, por não terem recebido uma educação formal, são como "bárbaros", à margem da sociedade, da cultura e do progresso. Como todo dizer cala uma série de outros que poderiam estar em seu lugar, observamos o silenciamento de sentidos que, em outros contextos, poderiam discursivizar a biblioteca escolar de uma maneira diferente, fazendo falar, por exemplo, o prazer de estar na biblioteca, participar de inúmeras atividades dinamizadoras dos acervos e abrir-se a outras significações, além dos fechados currículos escolares:

A inclusão do sujeito-escolar no processo educacional, via biblioteca, é considerada a maneira pela qual ele pode se constituir um 'cidadão responsável' [...] um 'membro útil da sociedade', o que, para nós, é uma pista linguística importante pois reforça o efeito utilitário e instrumental atribuído à própria biblioteca escolar, definida como o lugar em que o cidadão vai frequentar para se tornar útil e necessariamente integrado ao papel que lhe é reclamado no âmbito social da produção e produtividade. Não se discursiviza o prazer nem o deleite que poderiam advir do contato com os livros e outros materiais, mas se normatiza, tão somente, a serventia de adentrar esse espaço. (FERRAREZI; ROMÃO, 2008b, p. 330-331)

A partir disso, as funções da biblioteca escolar estariam limitadas ao apoio (e não ao centro) da aprendizagem, priorizando o currículo escolar, a promoção de livros (e não de outros materiais também) e o acesso universal à informação, como se ele fosse o fim, e não o início de práticas que coloquem o acervo em movimento, de forma mais crítica e criativa, que gerem realmente a oportunidade de exposição de "diferentes idéias, opiniões e experiências" (CONSELHO FEDERAL DE BIBLIOTECONOMIA, 2009, p.2). Limita-se, assim, o escopo de ação da biblioteca escolar, desconsiderando as várias outras funções e atividades que poderiam ser nela desempenhadas, indo de encontro aos sentidos de que a biblioteca não pode se restringir a um papel meramente didático-pedagógico, a apoiar o programa do professor, devendo ir além (PERROTTI, 2006); marcamos que tais sentidos evocam uma maneira mais ampla e polissêmica de discursivizar a biblioteca, que está ausente nos recortes a seguir:

[...] instrumento de desenvolvimento do currículo. (CONSELHO FEDERAL DE BIBLIOTECONOMIA, 2009, p.1, grifos nossos)

Apoiar a todos os estudantes na aprendizagem e prática de habilidades para a avaliação e uso da informação [...] favorecer o acesso a recursos locais, regionais, nacionais e globais e a oportunidade para que os estudantes exponham diferentes idéias, opiniões e experiências. (CONSELHO FEDERAL DE BIBLIOTECONOMIA, 2009, p.2, grifos nossos) 
[...] promove serviços de apoio à aprendizagem e livros aos membros da comunidade escolar. (MANIFESTO..., 2009, p.4, CARTA..., 2007, p.1, grifos nossos)

[...] não se pode viabilizar um processo de democratização da informação sem amplo acesso aos meios de cultura. (CARTA..., 2007, p.2, grifos nossos)

Entremeados a esses sentidos, a nosso ver restritos, estão aqueles presentes na "Carta de Brasília em Defesa da Biblioteca Escolar”, em cujo título, antevemos o funcionamento discursivo que nela se encontra, pelo qual, ao serem apresentadas as dificuldades e os problemas enfrentados pela biblioteca escolar inserida em um preocupante contexto educacional, ela é revestida de um caráter frágil, ocupando a posição daquele que deve ser discutido, protegido e defendido (assim como se apresenta também no Manifesto em Defesa da Biblioteca Escolar), por um sujeito legitimado, autorizado a enunciar, manifestar-se sobre ela. Pela deriva que constitui o discurso, garante-se a possibilidade de que a biblioteca possa ocupar, ao mesmo tempo, uma posição diferente, construindo outros sentidos, pelos quais ela chamada a exercer um papel mais ativo, que a distancie da inércia que lhe é historicamente atribuída, conclamando-a a intervir politicamente, fazendo com que "esta triste realidade" possa ser transformada.

Deste modo, observamos os sentidos que atribuem à biblioteca a possibilidade (inscrita na conjunção "se") de ser uma solução, uma saída para os preocupantes problemas educacionais enfrentados pela sociedade brasileira, os quais são também alvo de denúncia e críticas, parafraseadas nos documentos que analisamos. Temos, assim, que, ao serem satisfeitas as condições (consideradas ideais pelos órgãos de classe dos bibliotecários) de atuação, que incluem profissionais habilitados e acervos qualificados, as bibliotecas poderiam superar as dificuldades encontradas, como podemos observar nos recortes a seguir:

[...] preocupação com o momento pelo qual passa a educação no Brasil, com baixos índices de aprendizagem dos alunos, mensurados tanto pelo Sistema de Avaliação da Educação Básica (SAEB), quanto pelo Programa Internacional de Avaliação de Alunos (PISA), demonstrando que os estudantes brasileiros não possuem competência em leitura e escrita. (MANIFESTO..., 2009, p.4)

[...] importância da biblioteca na prática da leitura e escrita, um dos maiores problemas da educação atualmente [...] (MANIFESTO..., 2009, p.4)

Acompanhamos com preocupação o momento por que passa a educação no Brasil, com baixos índices de aprendizagem dos alunos, demonstrando que eles não possuem competência em leitura e escrita. Diante desse fato, acreditamos que se as instituições de ensino investirem na criação de 
espaços de bibliotecas bem equipadas, com acervos que atendam ao projeto político pedagógico das escolas e administradas por profissionais bibliotecários, está [sic] triste realidade poderá sofrer significativa transformação. (CARTA..., 2007, p.1, grifos nossos)

[...] acredita-se que se as instituições de ensino investirem na criação de espaços de bibliotecas bem equipadas, com acervos que atendam ao projeto político pedagógico das escolas e administradas por profissionais bibliotecários, esta triste realidade poderá sofrer significativa transformação. (MANIFESTO..., 2009, p.4, grifos nossos)

Sendo assim, a biblioteca escolar é discursivizada a partir de um lugar de importância e a rede funciona como um (ciber)espaço discursivo em que é possível materializar efeitos de luta e reivindicação que gravitem em torno da biblioteca escolar, instalando um litígio entre diferentes sentidos. Pela contradição que é constitutiva do discurso, é possível que os sentidos que colocam em discurso uma biblioteca ideal circulem lado a lado daqueles que os desconstroem, estabelecendo relações conflituosas, que chamam a atenção para a possibilidade (presidida pelas formações imaginárias) da biblioteca ocupar uma posição discursiva diferente do lugar social a partir do qual enuncia. Esse movimento foi flagrado, também, no Manifesto sobre a Biblioteca Escolar que, como o próprio nome ("manifesto") sugere, evoca sentidos circulantes no campo político que, por sua vez, serão deslocados e materializados na rede eletrônica, pra enunciar sobre a biblioteca escolar. Consideramos que a Internet pode ser entendida como um espaço discursivo heterogêneo, no qual também é possível instalar a dúvida acerca dos sentidos atribuídos a uma biblioteca escolar ideal, manifestar-se criticamente a respeito dela. Observa-se, assim, um embate entre diversas formas de discursivizar a biblioteca escolar, diferentes formações discursivas que se interpenetram, graças à porosidade de suas fronteiras.

Sendo assim, a rede eletrônica é um espaço político de disputas pelo dizer, onde é possível flagrar os movimentos de significação constituídos pelos sujeitos-bibliotecários, promovendo a circulação dos sentidos de denúncia acerca das condições precárias das bibliotecas, pelos quais se instaura a contradição entre o ideal de acesso universal a uma biblioteca e o panorama desanimador brasileiro, marcado pela inexistência e mau funcionamento das bibliotecas escolares, especialmente, da rede pública de ensino:

Ainda, é oportuno destacar que, na maioria dos casos, o horário de atendimento não é regular nem suficiente para atender aos estudantes, sendo que os raros frequentadores pouco usam ou têm consciência de suas potencialidades em termos de serviços. (MANIFESTO..., 2009, p.4, grifos nossos) 
[...] as escolas não possuem bibliotecas e muito menos bibliotecários [...] (MANIFESTO..., 2009, p.4, grifos nossos)

apresenta-se carente de um serviço cidadão (CARTA..., 2007, p.2, grifos nossos)

Abre-se, também, espaço para duvidar dos discursos legitimados que exaltam as ações governamentais distributivistas, supostamente, em prol da biblioteca escolar, para questionar a ordem vigente, através da indagação sobre a priorização da simples existência de um acervo na escola, em detrimento de sua dinamização no âmbito da biblioteca, como podemos observar nos próximos recortes:

No que pese ser esta a única iniciativa desenvolvida no âmbito da federação para as bibliotecas escolares, é tácito afirmar que tal Programa não atende as expectativas do contexto no qual se inserem as discussões apresentadas, pois, se as escolas não possuem bibliotecas e muito menos bibliotecários, como estão sendo dinamizados esses acervos? (MANIFESTO..., 2009, p.4, grifos nossos).

Ressalte-se que biblioteca escolar, embora se constitua em um espaço de aquisição e disseminação de cultura e informação, apresenta-se carente das condições adequadas para ofertar um serviço cidadão, no sentido de que está impedida de viabilizar um processo de democratização da informação com amplo acesso aos meios de cultura, uma vez que a sua existência está condicionada única e exclusivamente à presença de acervo, e não à oferta de serviços capazes de promover o acesso aos saberes registrados nos artefatos culturais que a biblioteca escolar deve disponibilizar. (MANIFESTO..., 2009, p.4, grifos nossos).

Inferimos que, apesar do reconhecimento de que o acesso ao acervo por si só não é suficiente, de que é preciso dinamizá-lo, não se avança em questões que apontem como isso seria possível, apagando-se os sentidos acerca de uma relação mais polissêmica com a linguagem, de uma postura mais plural da biblioteca escolar, que superem o ranço burocrático ainda presente nas bibliotecas brasileiras. Isso pode ser observado no embate entre os sentidos de crítica a práticas consideradas restritas e os que preconizam apenas a existência de bibliotecas, bibliotecários e acervos tecnicamente processados como formas de superar as dificuldades:

O gasto de numerário público, como já destacado, em simples aquisição e distribuição de acervo, principalmente composto de livros, sem abranger a existência, organização e manutenção de bibliotecas fere o interesse público, já que em última instância, esses recursos são extraídos dos cofres públicos a partir da arrecadação efetuada através do contribuinte, configurando-se em malbaratação do patrimônio cultural. (MANIFESTO..., 2009 , p.5, grifos nossos) 
[...] acredita-se que se as instituições de ensino investirem na criação de espaços de bibliotecas bem equipadas, com acervos que atendam ao projeto político pedagógico das escolas e administradas por profissionais bibliotecários, esta triste realidade poderá sofrer significativa transformação. (MANIFESTO..., 2009, p.4, grifos nossos)

[...] direito do cidadão em ter acesso a um espaço no qual a informação concretiza seu papel social, democratizante, vez que não se pode pretender que o acervo não processado de forma técnica, científica, atenda a essa função que, por ser social é garantia da construção da cidadania. (MANIFESTO..., 2009, p.5, grifos nossos)

É exatamente, diga-se de outro modo, a informação que se organiza, processa e se dissemina, após receber o tratamento adequado, que poderá atender ao cidadão em amplo raio de demandas e níveis de compreensão. (MANIFESTO..., 2009, p.5, grifos nossos)

É nesse espaço que a informação concretiza seu papel social, democratizante, vez que não se pode pretender que o acervo não processado de forma técnica, cientifica, atenda a essa função que, por ser social é garantia da construção da cidadania. É exatamente, repita-se, a informação que se organiza, processa e se dissemina após receber o tratamento adequado, que poderá atender ao cidadão em amplo raio de demandas na construção da educação cidadã. (CARTA..., 2007, p.2, grifos nossos)

Consideramos que é importante que a biblioteca conte com recursos que permitam que ela se torne um ambiente agradável e desejável, dotada de acervos organizados e disponíveis, entretanto, ressaltamos que esses recursos devem ser postos em movimento, e não, como sugerem os recortes anteriores, apenas estarem disponíveis para o acesso e utilização em atividades escolares que, geralmente, são desempenhadas de forma repetitiva em grande parte das escolas brasileiras, que sustentam ainda a transmissão e não a construção do conhecimento.

Os discursos que atribuem sentidos de passividade e restrição à biblioteca escolar entremeiam-se a outros que procuram valorizá-la, colocá-la em movimento, em direção aos sujeitos leitores, através de ações que a desprenderiam do plano teórico e estariam voltadas, principalmente, para a sua maior visibilidade, furando, assim, o silenciamento a que muitas vezes é submetida. Dentre essas ações propostas, destacam-se a "elaboração de um manifesto a favor da biblioteca escolar a ser publicado em todos os jornais do país"; "Eleger uma figura pública para apoiar o movimento" e "levantar e expor as boas práticas existentes no país." (MANIFESTO..., 2009, p.5), que seriam realizadas pelos órgãos de classe, a partir da implicação do sujeito nesse discurso, que assumiria uma posição de mobilização, de reivindicação do que é considerado como direito básico, legitimado pela lei: 
[...] as organizações abaixo-assinadas reivindicam o respeito aos princípios estabelecidos na Constituição Federal (1988), no que tange ao direito do cidadão em ter acesso a um espaço no qual a informação concretiza seu papel social, democratizante [...] (MANIFESTO..., 2009, p.5).

Assim, insere-se o sujeito-bibliotecário em um lugar de poder, de importância, a partir do qual ele deveria assumir um papel de destaque, frente aos desafios impostos às bibliotecas escolares. Observamos que os discursos circulantes nos documentos do CFB e CRBsorganizações sociais imbuídas do poder de falar, supostamente, em nome de todos os bibliotecários, representando claramente as suas opiniões e interesses- evocam sentidos de valorização desses profissionais e, também, de denúncia frente à sua inexpressiva presença nas escolas brasileiras. Esses sentidos, que parecem óbvios, sendo natural que em toda biblioteca haja um bibliotecário, ainda não estão presentes, de forma maciça, nos documentos jurídicos brasileiros. Para reforçar os sentidos de importância e prestígio desse profissional, considerado como aquele que detém o saber necessário para atuar nas bibliotecas, desqualificam-se outros que, por não terem os mesmos conhecimentos que eles, estariam expondo-se aos perigos, a essa imprudência de desempenhar tarefas para as quais não foram preparados, estando fadados ao fracasso:

[...] a grande maioria dos responsáveis técnicos e diretores das escolas não tem noção dos serviços que podem ser oferecidos pelas bibliotecas. [...] (MANIFESTO..., 2009, p.4)

Os diretores das escolas e os responsáveis técnicos não têm domínio sobre a concepção do funcionamento de uma biblioteca e se arriscam ao apontar a dimensão do espaço físico destinado a leitura como única diferença entre biblioteca e sala de leitura. [...] (MANIFESTO..., 2009, p.4)

A Lei no 4.084, de 30 de junho de 1962, dispõe sobre a profissão de Bibliotecário e regula seu exercício. Em seu Art.6 o determina '[...] que entre as atribuições dos Bacharéis em Biblioteconomia estão a organização, a direção e execução dos serviços técnicos de repartições públicas federais, estaduais, municipais e autárquicas e empresas particulares'. O exercício dessas funções por leigo constitui uma infração a legislação vigente e, principalmente, fere o direto constitucional do cidadão de receber a prestação de serviços por profissional especializado e habilitado [...] (CARTA..., 2007, p.2, grifos nossos)

Nessa perspectiva, recorre-se mais uma vez à citação de documentos jurídicos, para conferir um efeito de veracidade e comprovação aos sentidos enunciados, que sustentam uma crítica a tudo aquilo que é considerado inadequado em relação à biblioteca, como, por exemplo, a presença do "leigo", cujo avesso é a inexistência do bibliotecário (inserido em um lugar de poder e saber), a qual é vista, a partir dessa perspectiva, como um desrespeito à lei, 
uma infração dos direitos do cidadão, atestados em vários documentos jurídicos que são retomados para fazer falar a necessidade e importância das bibliotecas e dos bibliotecários.

Posto isto, a partir do que foi exposto até aqui, podemos inferir que a Internet é um espaço discursivo, atravessado por relações de força, lutas pelo poder saber e dizer, pelas quais o sujeito pode resistir, fazer ecoar sentidos de denúncia, rompendo os efeitos de silenciamento da biblioteca e do bibliotecário. Deste modo, em meio aos sentidos repetitórios, flagramos a emergência de outros, que se entremeiam a eles, instalando um litígio entre o mesmo e o diferente. Após estas considerações, passaremos àquelas referentes ao labirinto virtual da Internet. 
3 NOS LABIRINTOS DA INTERNET: REDES EM MOVIMENTO

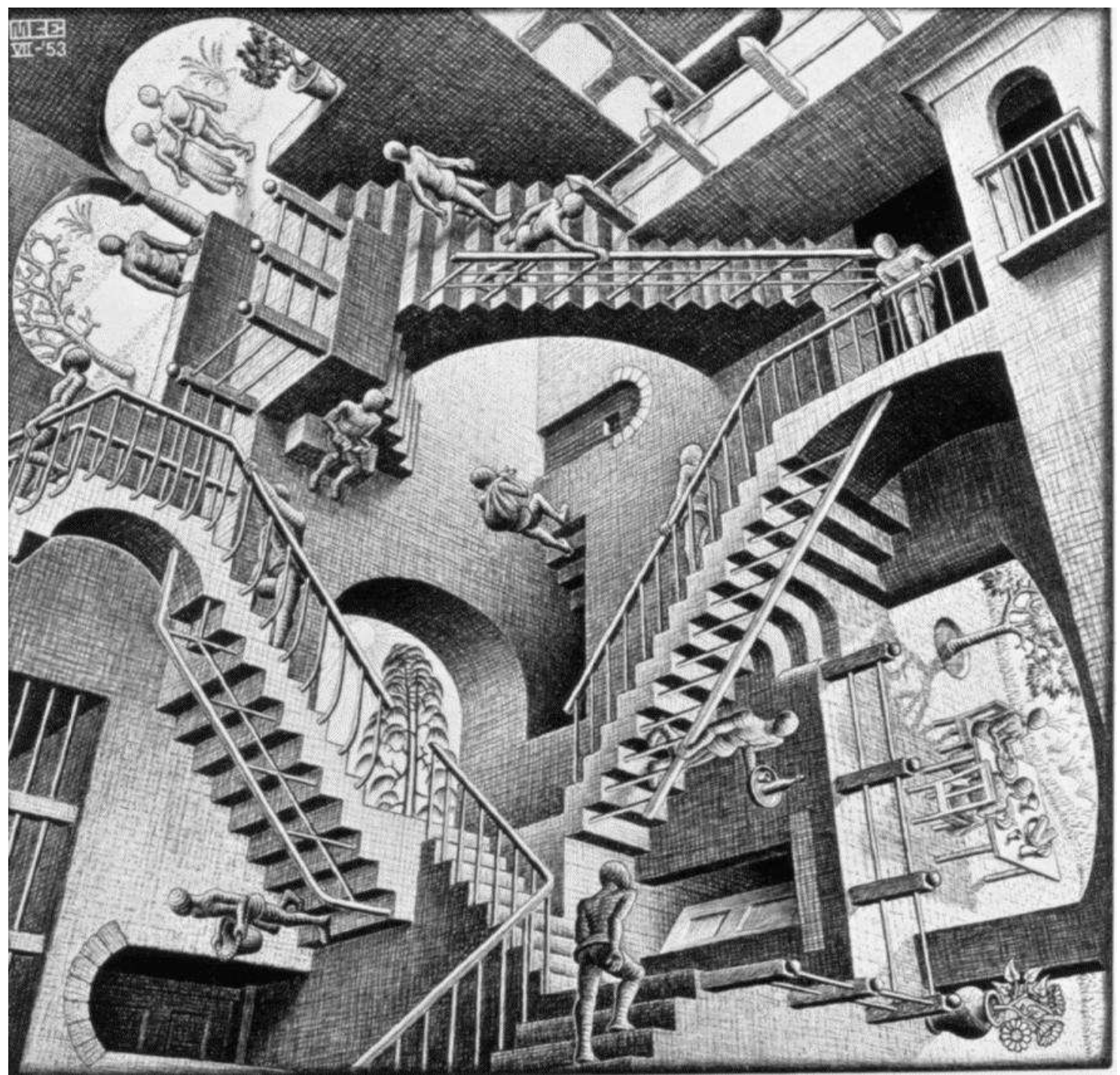

Figura 3. Relativity

No habrá nunca una puerta. Estás adentro/ Y el alcázar abarca el universo/ Y no tiene ni anverso ni reverso/ Ni externo muro ni secreto centro. (BORGES, 1989, p.364) 
Como analistas do discurso, consideramos que explorar o labirinto implica rastrear as diversas redes de memória que o significam e abrigam diferentes efeitos de sentido, que podem ser atualizados pra discursivizar a estruturas presentes no corpo humano, na natureza ou as edificações construídas pelo homem. Entretanto, interessa-nos aqui investigar outro tipo de labirinto: o virtual da rede eletrônica, que é visto por Leão (2002, p. 18) como "rizomático, conectável em várias direções e de todos os seus pontos”. Ao longo deste capítulo, apresentaremos algumas considerações acerca da materialidade que compõe tal labirinto, mas já é possível antevermos, no poema de Borges e na gravura de Escher que inauguram esse capítulo, algumas pistas de sua constituição, sua natureza fluida, indicada pela ausência de um centro controlador, de limites rigidamente estabelecidos e de percursos previamente traçados para aqueles que se aventuram no espaço virtual, a partir de diferentes perspectivas, posições.

É importante ressaltarmos que estamos empregando o termo "virtual", tal como Lévy (1996) o postula, entendendo-o não como oposição à realidade, mas sim à atualidade. Deste modo, o virtual é o possível, o vir-a-ser, o que existe em potência, e não em ato; assim como árvore está virtualizada na semente, os sentidos estão latentes sob a materialidade da palavra à espera de/para serem atualizados, ressignificados pelos sujeitos-navegadores em seus múltiplos trajetos possíveis nas redes labirínticas da Internet. Assim sendo, é a partir de cada movimento do sujeito que se constitui o labirinto virtual de que falamos, pois, conforme Leão (2005, p.114) observa, ele "só passa a existir como tal, como construção da complexidade, na medida em que alguém o penetre e o percorra."

Posto isto, nesse trabalho gostaríamos de atualizar alguns possíveis percursos de sentido, quais sejam, os que nos levem a compreender, à luz dos conceitos da Análise do Discurso de linha francesa, como a biblioteca escolar está sendo discursivizada neste (ciber)espaço labiríntico, de que maneiras a historicidade e a memória discursiva (PÊCHEUX, 1997) sustentam sentidos sobre esta instituição, observando o litígio entre diferentes posições de sujeito autor e leitor, que se movimentam e se constituem ao mesmo tempo que os sentidos, nas páginas eletrônicas. Para que possamos compreender estes movimentos de sujeitos e sentidos na Internet, é fundamental que investiguemos a maneira como se estruturam as redes de computadores, a sua topologia labiríntica que modifica as "nossas formas de relação com o conhecimento, de relações entre os sujeitos, de relações com a sociedade e com a própria materialidade do discurso." (DIAS, 2005, p. 41). Porém, antes de falarmos a respeito da materialidade constitutiva da rede eletrônica e das possibilidades de construção de sentidos que são abertas por ela, é importante que a situemos no contexto sóciohistórico que propiciou sua emergência, qual seja, o pós-moderno, que é visto, por Jameson 
(2006), como a lógica cultural do capitalismo tardio ou multinacional, de uma sociedade pósindustrial, que teve suas origens no período pós-segunda guerra.

Sendo assim, observamos que falar do discurso, tal como Pêcheux (1997) nos orientou, reclama levar em conta as condições de produção, ou seja, considerar a exterioridade que constitui a própria linguagem. O discurso é sempre datado sóciohistoricamente e essa condição nos faz rastrear os lugares sociais em que as palavras foram ditas, o modo como a tensa disputa por regiões de poder dá-se a sustentar em atos de linguagem, as formações sociais que determinam as formações ideológicas, marcando o que pode e deve ser dito nas redes na Internet.

\title{
3.1 Do social ao discursivo: considerações sobre as condições de produção de sentidos nas redes labirínticas da Internet
}

\begin{abstract}
Todas as relações fixas e cristalizadas, com seu séquito de crenças e opiniões tornadas veneráveis pelo tempo, são dissolvidas, e as novas envelhecem antes mesmo de se consolidarem. Tudo o que é sólido e estável se volatiliza, tudo o que é sagrado é profanado, os homens são finalmente obrigados a encarar com sobriedade e sem ilusões, suas posição na vida e suas relações recíprocas. (MARX; ENGELS, 1988, p. 69)
\end{abstract}

A instigante assertiva que nos serve de epígrafe bem poderia referir-se ao contexto sócio-histórico em que vivemos, marcado pela transitoriedade, fugacidade e que nos convida à reflexão; entretanto, tendo sido publicada em 1848, assume um tom quase profético. Ao retomar essas considerações de Marx e Engels (1988) e outras enunciadas por demais autores, entre meados do século XIX e início do XX, Bucci (2008, p.3) observa como as transformações velozes, a aceleração dos novos tempos não são um fenômeno restrito à contemporaneidade, visto que tem sido observado há algum tempo: "já faz tempo que tudo muda o tempo todo [...] Portanto, quando digo que não é novidade que vivemos uma era de fetiches tecnológicos, não me valho apenas de uma força de expressão. Não é novidade mesmo. Faz mais de um século que não é novidade. Pelo menos um século.”

$\mathrm{O}$ advento do ciberespaço e suas redes virtuais parece potencializar os efeitos dessa provisoriedade contemporânea, apontando a exacerbação de um processo que vem se desenvolvendo, agora de forma mais dinâmica, e que não é apenas técnico, mas também político, histórico, social, econômico e ideológico. Nesse contexto de mudanças, "o que é 
virtual também se desmancha - no sólido. Que por sua vez desmorona de novo. No vácuo. Não há ponto de repouso, ou de fixação, que não seja a voragem elétrica de bits, cuja direção é um mistério". (BUCCI, 2008, p. 4).

Assim como a Internet e suas inúmeras redes, a chamada "pós-modernidade" está ainda em um processo recente de construção e desenvolvimento, que vem gerando muitas discussões e divergências, sendo entendida ora como uma ruptura em relação ao moderno (como indicia o prefixo "pós"), ora como parte dele (FEATHERSTONE, 1995). Prova disso é o confuso emprego e a quantidade de rótulos e nomeações que a atualidade recebe: modernidade líquida, modernidade tardia, hipermodernidade, dentre outros. Não é nosso objetivo aprofundarmos a questão da pós-modernidade, mas faz-se necessário apontarmos algumas características, que são constitutivas deste contexto atual e que nos auxiliam a compreender o nosso objeto de pesquisa. Dentre elas, podemos citar a subversão do paradigma moderno de cunho positivista, que impunha uma lógica homogênea, transparente, hierárquica e rigidamente estruturada. Segundo Bauman (2001), essa "modernidade pesada", marcada pela conquista do espaço e o tempo rotinizado das fábricas, foi suplantada por uma "modernidade líquida”, na qual o sedentarismo dá lugar ao nomadismo.

Ao invés de uma visão do conhecimento e da própria sociedade como uma estrutura fechada, temos, no âmbito pós-moderno, a valorização de uma concepção de descentramento, "uma infinidade de termos e pontos assincrônicos que não estão acabados, mas em contínua (re)produção e negociação de sentidos e informações, gerando novos discursos, numa permuta sem regras fixas e sempre aberta a construções diferentes" (RAMAL, 2002, p.89). Assim sendo, são postas em cheque as verdades incontestáveis, a estabilidade, conforme nos fala Lyotard (2004, p. xi):

O que temos é a crise de uma noção central nos dispositivos de legitimação e no imaginário modernos: a noção de ordem. E com ela assistimos à rediscussão da noção de 'desordem', o que por sua vez torna impossível submeter todos os discursos (ou jogos de linguagens) à autoridade de um meta-discurso que se pretende a síntese do significante, do significado e da própria significação, isto é, universal e consistente.

Por conseguinte, a crença em um sentido unívoco e universal pode ser contestada, instigando nosso olhar "para o que é heterogêneo, marginal, marginalizado, cotidiano, a fim de que a razão histórica ali enxergue novos objetos de estudo". (LYOTARD, 2004, p. 127). Abrem-se, assim, lacunas, furos nas formações discursivas dominantes, trazendo à tona outras vozes e discursos, historicamente segregados, silenciados; o que pode ser observado muitas vezes nos mares revoltos do ciberespaço, abertos a outros sentidos, a sites, páginas virtuais 
que abarcam o mesmo, mas também a possibilidade de um vir-a-ser diferente. Consideramos, assim, que a pluralidade, transitoriedade e ausência de contornos rígidos, que ganham destaque no âmbito pós-moderno, são também características do labirinto virtual da Internet, suscitando diferentes modos de sujeitos e sentidos inscreverem-se em suas redes. Com o seu olhar de filósofo, Lévy (1999, p. 121) vai ao encontro de nossa concepção, quando considera que essa profusão de possibilidades múltiplas é marca da conjuntura pós-moderna e da decorrente cibercultura: "a multiplicidade e o entrelaçamento radical das épocas, dos pontos de vista e das legitimidades, traço distintivo do pós-moderno, encontram-se nitidamente acentuados e encorajados na cibercultura". Outro traço importante, que vem afetando a produção de sentidos na contemporaneidade, diz respeito às mudanças nas noções de tempo e espaço, em relação à modernidade, o que é abordado por Lemos (2007, p. 67-68):

O espaço e o tempo pós-modernos não podem mais ser percebidos como seus correlatos modernos. David Harvey desenvolve uma tese de acordo com a qual uma mudança cultural (espaço-temporal) está em marcha desde, pelo menos, a década de $70 \mathrm{com}$ a estabilização da cultura de massa. Na modernidade o tempo é linear (progresso e história) e o espaço é naturalizado e explorado enquanto lugar de coisas (direção, distância, forma, volume). Na modernidade, o tempo é um modo de esculpir o espaço, já que o progresso, a encarnação do tempo linear, implica a conquista do espaço físico. Na pós-modernidade, o sentimento é de compressão do espaço e do tempo, onde o tempo real (imediato) e as redes telemáticas, desterritorializam (desespacializam) a cultura, tendo um forte impacto nas estruturas econômicas, sociais, políticas e culturais. O tempo é, assim, um modo de aniquilar o espaço. Este é o ambiente comunicacional da cibercultura.

Bauman (1999) aponta alguns aspectos semelhantes aos que foram tratados por Lemos (2007), enfocando a rigidez, solidez e perenidade de um espaço moderno, construído de aço e concreto e movido por malhas de ferrovias e rodovias; ainda segundo o autor:

Sobre esse espaço planejado, territorial-urbanístico-arquitetônico, impôs-se um terceiro espaço cibernético do mundo humano com o advento da rede mundial de informática. Elementos desse espaço, de acordo com Paul Virilio, são 'desprovidos de dimensões espaciais, mas inscritos na temporalidade singular de uma difusão instantânea'. (BAUMAN, 1999, p. 25).

Isto fará com que as distinções entre aqui e lá não signifiquem do mesmo modo como se dão a conhecer na realidade empírica, dando-nos a impressão de que as distâncias existem apenas para serem anuladas, como se o espaço fosse um convite a ser desrespeitado, visto que deixou de ser um obstáculo, bastando apenas uma fração de segundo para conquistá-lo. Sendo assim, não haveria mais fronteiras naturais, tampouco lugares óbvios a serem ocupados; 
vivendo em um presente e mudança perpétuos (JAMESON, 2006; MANGUEL, 2006), temos uma ânsia de estarmos em movimento, pois, segundo Bauman (1999, p. 85), "onde quer que estejamos em determinado momento, não podemos evitar de saber que poderíamos estar em outra parte, de modo que há cada vez menos razão para ficar em algum lugar especifico". Podemos inferir que os sujeitos inseridos neste (ciber) espaço flutuante, cuja paisagem continuará a fluir e girar à sua volta, constroem "sua discursividade na fugacidade, também marcada pela possibilidade de dizer e escrever, na tela, a fantasia que lhe é interditada na realidade" (ROMÃO, 2005b, p.7). Por conseguinte, temos que os sujeitos podem ocupar diferentes posições, em um ambiente não delimitado pelo tempo linear da história, nem pela noção de geografia que constitui o impresso. É importante considerarmos que, apesar de propiciarem inúmeras possibilidades de se ocupar outros espaços discursivos, as redes da Internet também são feitas de lacunas, de ausências, o que é confirmado por Romão (2004b, p.1): "ocorre que, ao mesmo tempo em que os pontos e os nós compõem a geometria do trançado, há espaços de brechas, desvãos e buracos, que criam poros abertos, por onde escorregam vazios, escapam silêncios, escorrem os não-ditos e interditos". Observamos que essa incompletude, que caracteriza o discurso, o sujeito e também a rede eletrônica, é frequentemente silenciada nos discursos que atribuem à Internet um ilusório lugar de plenitude.

Assim, ressaltamos que este cenário pós-moderno, "essencialmente cibernéticoinformático e informacional" (LYOTARD, 2004, p. xiii), é marcado por várias colorações de otimismo em relação às novas tecnologias, fornecendo as bases para o desenvolvimento da chamada cibercultura. Acreditamos que, para que as tecnologias de inteligência inaugurem uma sequência de acessos, é preciso considerar as desigualdades sociais brutais que regem a atualidade e que mantêm à margem dos acessos populações inteiras; questões a serem abordadas na próxima seção. Por ora, interessa-nos investigar como os teóricos da pósmodernidade discursivizam a cibercultura, tomando-a em uma região de sentidos diferente da expressão cibernética, pois "não é, no sentido exato, correlata a essa ciência. Antes, a cibercultura surge com os impactos socioculturais da microinformática" (LEMOS, 2007, p. 101) e não é apenas uma questão de ordem tecnológica, visto que constitui, a partir da convergência entre o social e o tecnológico, uma rede social complexa, que revela novas formações socioculturais; segundo Santaella (2003, p.77): "não restam dúvidas quanto ao fato de que estamos vivenciando o alvorecer de novas formações socioculturais que vem recebendo tanto o nome de cultura digital, quanto de cibercultura". Cabe ressaltarmos que esses novos fios da trama social serão tecidos em um bordado discursivo diferente e 
inconcluso, que se (re)arranja em sentidos outros, que se desmancha no ar à espera do ponto seguinte, do próximo nó.

Ao investigar o caráter plural dessa cultura digital, Lévy (1999, p.17) tece considerações que a tomam como um "conjunto de técnicas (materiais e intelectuais), de práticas, de atitudes, de modos de pensamentos e de valores que se desenvolvem juntamente com o crescimento do ciberespaço." Ressaltamos que esse conjunto sortido, que pode parecer caótico e extravagante, não se restringe a ser uma subcultura particular de algumas "tribos" (LEMOS, 2007), ou de "fanáticos pela rede" (LÉVY, 1999), mas se trata de uma nova forma de cultura na qual nos inserimos, tal como o fizemos há alguns séculos em relação à cultura alfabética, cabendo aqui uma ressalva: "a cibercultura não é uma negação da oralidade ou da escrita, ela é o prolongamento destas" (LEMOS, 2007, p.11). Com o advento da cibercultura, não temos uma substituição das formas de culturas mais tradicionais (cultura oral, escrita, impressa, de massas e das mídias), visto que:

não se trata aí de períodos culturais lineares, como se uma era fosse desaparecendo com o surgimento da próxima. Ao contrário, há sempre um processo cumulativo de complexificação [...] uma nova formação comunicativa e cultural vai se integrando na anterior, provocando nela reajustamentos e refuncionalizações. (SANTAELLA, 2003, p.13)

No âmbito das mudanças suscitadas pelas tecnologias de informação e comunicação, que implicam "uma revolução da técnica de produção dos textos, uma revolução do suporte do escrito e uma revolução das práticas de leitura" (CHARTIER, 2002, p. 113), destacam-se processos como o de digitalização e convergências das mídias, pelos quais se torna possível que o discurso seja produzido e circule em diferentes materialidades- texto, som, vídeo- nas redes da Internet (SANTAELLA, 2003). Este caráter mutável e abrangente da rede faz parte de uma (ciber)cultura da mobilidade (LEMOS, 2004), que ganha força em tempos ditos pósmodernos e é pautada por mudanças que nos levam a um ideal de universalidade sem totalidade, "ao momento em que nossa espécie, pela globalização econômica, pelo adensamento das redes de comunicação e de transporte, tende a formar uma única comunidade mundial, ainda que essa comunidade seja- e quanto!- desigual e conflitante." (LÉVY, 1999, p.249).

Tal comunidade é representada pela Internet que, através de suas múltiplas redes, agrega sujeitos que produzem seus dizeres a partir de condições sócio-histórico-ideológicas muito diversas, as quais, muitas vezes, são apagadas, deslocadas, diluídas em um grande mar de sujeitos e sentidos à deriva. É importante ressaltarmos, conforme já adiantamos, que, 
apesar da possibilidade da cibercultura e suas redes eletrônicas estenderem-se às várias regiões do globo, ampliando e acelerando a comunicação de uma forma inédita, duvidamos do caráter universal atribuído, por Pierre Lévy, à comunidade formada pelos sujeitosnavegadores da rede. A seguir, falaremos acerca das (im)possibilidades de velejar nos mares do ciberespaço, que nos fazem desconfiar dessa universalidade.

\title{
3.1.1 Das (im)possibilidades de navegação nos info-mares
}

\author{
E quanto mais remo mais rezo \\ Pra nunca mais se acabar \\ Essa viagem que faz \\ O mar em torno do mar \\ Meu velho um dia falou \\ Com seu jeito de avisar: \\ - Olha, o mar não tem cabelos \\ Que a gente possa agarrar (VIOLA; CARVALHO, \\ 1996)
}

Os mares agitados do ciberespaço, cujas delícias e intempéries só podem ser conhecidas à medida que se lança em suas águas, convidam o sujeito-navegador a um velejar constante, ao sabor das ondas que o levem a lugares desconhecidos, num ir-e-vir desejoso de "nunca mais se acabar". Tal qual o timoneiro de que se fala na letra da canção que nos serve de epígrafe, o sujeito-navegador de info-mares defronta-se com a impossibilidade de controlálos, de "agarrá-los" em sua totalidade. Esta impossibilidade nos faz pensar nos limites e barreiras impostos aos movimentos de navegação dos sujeitos pela rede eletrônica, leva-nos a desconfiar dos sentidos, aparentemente evidentes, de que a rede é um mar aberto de possibilidades ilimitadas e disponíveis a todos aqueles que nele se aventuram.

É importante apontarmos algumas restrições, tempestades que fazem com que os sujeitos-navegadores fiquem à deriva ou, antes disso, sejam impedidos de içar velas. Pensamos, assim, que não é possível acreditar na fantasia da infinitude, de uma tagarelice livre e sem limites, pois na fluida e incerta materialidade da rede eletrônica, permeada por relações de força, nem todos os discursos são autorizados a circularem, moverem-se por esse espaço ciber, cuja emergência, segundo Lévy (1999, p.161), "não significa de forma alguma que 'tudo' pode enfim ser acessado, mas antes que o Todo está definitivamente fora de alcance". Da mesma forma, nem todos os sujeitos podem tomar a palavra, fazendo com que eles sejam excluídos do ciberespaço ou estejam presentes apenas através da voz de um outro, que enuncia sobre ele, como podemos observar nos sites de movimentos sociais. Tais impedimentos também foram observados por Foucault (2005, p. 9), quando ele diz que: 
"sabe-se bem que não se tem o direito de dizer tudo, que não se pode falar de tudo em qualquer circunstância, que qualquer um, enfim, não pode falar de qualquer coisa.”. Para compreendermos como se dão tais movimentos de restrição (dos quais falaremos nesta seção) e ampliação (a serem abordados mais adiante) das possibilidades de estar e significar na rede, é fundamental observarmos as condições de ordem sócio-histórica e ideológica que os regulam, levando-nos a considerar a Internet um espaço discursivo em que o excesso e a falta se entremeiam, no qual algumas portas se abrem a novos discursos e sujeitos, enquanto outras se fecham, numa relação conflituosa que indicia a heterogeneidade e multiplicidade constitutiva de discursos sempre em (re)construção e deslocamento.

Dentre os muitos poderes em jogo no ciberespaço, Sorj (2003) nos fala a respeito dos confrontos entre as redes (representadas por sujeitos-internautas ávidos por conteúdos gratuitos e liberdade de acesso) e as pirâmides (representadas por Estado e empresas), que ocupam uma posição de autoridade e controlam o acesso e fluxo de informações na Internet, muitas vezes em nome da segurança. Assim sendo, segundo Castells (2003a, p.141), "uma variedade de tecnologias de controle emergiu dos interesses entrelaçados do comércio e dos governos. Há tecnologias de identificação, de vigilância e de investigação", as quais desencadeiam conflitos e movimentos de resistência, pelos quais se busca desenvolver tecnologias de proteção da privacidade. Uma série de notícias, veiculadas em diversas mídias, apontam estes embates, casos de oposição e polêmica em relação às iniciativas governamentais de tentar, com o auxílio de empresas privadas, censurar sites considerados não-apropriados. A título de exemplo, citamos a recente censura chinesa ao popular motor de busca Google, onde "serviços censuram certas expressões e temas que o governo local considera sensíveis, como o Massacre da Paz Celestial e a luta pela libertação do Tibet" (GOOGLE, 2010); esse movimento de silenciamento indicia as relações de poder que envolvem a tomada da palavra, as tentativas de impedir o sujeito de ocupar certas posições, de se identificar com certas regiões de dizer pelas quais ele se representa como (socialmente) responsável, como autor. (ORLANDI, 1997).

Podemos mencionar também a censura a blogs, sites de relacionamento e redes sociais (como o Orkut, Twitter, Facebook, My Space, YouTube, etc) no Irã e também na China (SERRANO, 2009). No caso chinês, apesar de o governo ter adiado o plano de obrigar todos os computadores vendidos no país a virem com o software "Green Dam Youth Escort" (que age como um filtro, impedindo o acesso a sites proibidos), algumas empresas chinesas já vendem computadores com o programa. (FABRICANTES, 2009). Cabe ressaltarmos que estes movimentos em direção à censura não são exclusividade de regimes políticos mais 
fechados, ocorrendo também em países tidos como democráticos, como, por exemplo, Austrália, Grã-Bretanha, Alemanha, etc. (MARTINS, 2009).

Em relação ao Brasil, citamos um estudo que está sendo realizado, pelo Conselho de Altos Estudos e Avaliação Tecnológica, a respeito dos crimes cometidos na Internet. O relator deste estudo (o deputado Colbert Martins) acredita que o respaldo de especialistas pode facilitar a aprovação do polêmico projeto de lei 84/99 que, se for aceito, obrigará os provedores de acesso à Internet a guardarem os dados do internauta e de sua conexão, tais como o horário, data e os endereços eletrônicos visitados. Este projeto, que é alvo de muitas críticas, já foi aprovado pela Câmara, revisado no Senado e voltou à Câmara, onde tramita em regime de urgência. (CONSELHO, 2009). Inferimos que as iniciativas supracitadas de vigilância e censura na rede, assim como outras tantas que deixamos de mencionar, indiciam as relações de força que determinam o que pode ou não ser dito em uma dada conjuntura (PÊCHEUX, 1997); tais considerações reforçam nossa concepção de que é ilusório o ideal de liberdade total para os sujeitos-internautas e apontam a necessidade de reflexão acerca das relações entre língua e ideologia. Outros fatores restritivos da navegação pelas redes da Internet e que merecem ser considerados são aqueles relacionados à posse de recursos financeiros para o pagamento tanto do acesso à Internet (no próprio domicílio ou em lugares públicos), quanto de seus conteúdos restritos. Blattmann e Fragoso (2003, p.61) apontam alguns destes limites:

A princípio acredita-se que tudo é permitido, desde acessar recursos diversificados, tais como ambientes de discussão (listas de discussões, fóruns, chats), páginas de hipermídia (homepages, revistas, catálogos, guias) e hipermídias (entre elas os filmes, a programação televisiva e de rádios online). Mas, gradativamente, os limites são descortinados, sejam de acesso a determinadas informações, ambientes restritos com cadastramento ou até mesmo pagamento de produtos e serviços tais como consultas a bases de dados, aos jornais e às revistas eletrônicas, ou mesmo da área comercial, que necessita do perfil para cativar e explorar o consumidor e gerar lucros.

Por conseguinte, não podemos ignorar os fatores de ordem sócio-econômica, dentre outros, que são responsáveis pelos furos nesse ideal de "acessibilidade ilimitada" que, para Melo (2005, p. 143) "seria não mais do que uma possibilidade técnica e poucas vezes uma prática real". Sendo assim, há espaços restritos, senhas, assinaturas, dentre outros empecilhos que impedem ou dificultam a circulação dos sujeitos-internautas e revelam as relações de poder e saber que são escamoteadas nessa aparente liberdade de poder clicar o mouse e entrar em qualquer site, criado algures, por um sujeito desconhecido ou anônimo, conforme nos conta Romão (2008, p. 98-99): 
Pagar, ser assinante e ter a senha são marcas que reclamam a significação de que o tudo e o todos da rede eletrônica tem relação com o poder econômico, ou seja, não se sustenta o mito da acessibilidade sem fronteiras nem a abertura infinita da rede para todo sujeito, pois, como esse exemplo mostra, há cancelas e portões chaveados a atravessar, muitos dos quais sem possibilidade de abertura, visto que a entrada não se situa apenas na página, mas muito antes dela, por exemplo, no boleto pago no banco. Desse modo, existem redes privadas dentro da grande rede com lugares cativos e reservados para poucos; há salas vips nas quais só podem entrar aqueles que possuem um determinado bilhete de identificação; há espaços restritos, aos quais não são todos os sujeitos que tem acesso tampouco são permitidas a sua entrada ou permanência; há assinaturas virtuais dispersas dentro da grande rede que fazem falar a condição de pagante e que fronteirizam a exclusão em suporte que, imaginariamente, proporcionaria a inclusão de todos de maneira homogênea.

Deste modo, julgamos importante considerar não apenas os sentidos constituídos na Internet, os sujeitos que circulam em suas redes, mas também os que não estão lá, levando em conta que algo sempre falta e falha. Posto isto, observamos que, apesar do uso da Internet estar se difundido rapidamente, "essa difusão segue um padrão espacial que fragmenta sua geografia segundo riqueza, tecnologia e poder: é a nova geografia do desenvolvimento" (CASTELLS, 2003a, p.174), que delineia, dentro dos países, grandes diferenças na difusão do uso da Internet.

Chegamos, assim, à importante questão da exclusão digital que, segundo Sorj (2003, p. 13), pode ser entendida como "a distribuição desigual entre os países- e no interior de cada sociedade- dos recursos associados às tecnologias da informação e da comunicação". Como tais tecnologias estão, cada vez mais, presentes no cotidiano de uma não-desprezível parcela da população mundial, não ter acesso a elas é considerado frequentemente um grave problema, uma falta que coloca o sujeito em uma posição de privação e exclusão. Segundo Castells (2003a, p. 8), “atividades econômicas, sociais, políticas e culturais essenciais por todo o planeta estão sendo estruturadas pela Internet e em torno dela, como por outras redes de computadores", portanto, estar à parte deste fluxo febril de informações e sujeitos em movimento constituiria uma das mais danosas formas de exclusão, uma forma de injustiça, como considera Milanesi (2002, p. 104-105):

Se a distribuição de riquezas materiais é injusta, mais ainda é a impossibilidade de acesso à informação - esta que seria o instrumento mais poderoso para superar condições que tornam os homens desiguais. Excluir a informação das necessidades básicas - vista às vezes como inútil ou perigosa é cortar pela raiz um direito sem o qual os indivíduos perdem outros. 
É importante salientarmos que a exclusão digital não pode ser dissociada do acesso a outras tecnologias de comunicação, assim como está fortemente relacionada às desigualdades sociais, visto que as taxas mais altas da chamada infoexclusão encontram-se nos setores mais pobres da população (SORJ, 2003). Estes grupos sofrem não apenas com a falta de acesso a estas tecnologias, na medida em que muitos ainda não contam com energia elétrica em suas casas, nem possuem conhecimentos específicos como os de informática e inglês ou mesmo são alfabetizados. A questão do analfabetismo é um dos graves entraves à inclusão desses setores na rede, já que "apesar dos avanços conquistados nos últimos anos na alfabetização dos brasileiros, a ainda precária formação de parte dos nossos cidadãos continua um fator relevante para que eles estejam excluídos desse processo." (SANTOS, 2009, p.45).

Dados do Indicador de Alfabetismo Funcional (INAF), correspondentes à última pesquisa realizada pelo Instituto Paulo Montenegro (2009), revelam que, em 2007, 7\% da população brasileira ainda era analfabeta. Entretanto, é importante ressaltamos que ser alfabetizado não significa ter as mesmas habilidades e práticas de leitura, escrita e matemática, o que nos leva a considerar que $25 \%$ da população tem um nível rudimentar de alfabetização, $40 \%$ pode ser considerada alfabetizada nível básico e apenas $28 \%$ dos brasileiros são alfabetizados em nível pleno. Tais cifras indiciam o caráter não-homogêneo da navegação pelas redes virtuais da Internet, pois os movimentos dos sujeitos-internautas são afetados pela exterioridade de maneiras muito distintas, por formações sociais, ideológicas e discursivas que levam à atualização de determinadas regiões de memória discursiva e não outras, no ir-e-vir de links e páginas eletrônicas.

Citaremos aqui algumas outras cifras, relativas ao acesso às redes eletrônicas e aos computadores, que nos ajudam a investigar as condições de produção dos dizeres circulantes (ou interditados) na Internet, lembrando-nos que os discursos analisados ao longo deste trabalho fazem ressoar a voz de sujeitos que ocupam uma posição social privilegiada, fazendo parte do seleto grupo dos "infoincluídos", que lhes permite entrar no ciberespaço e falar sobre a biblioteca escolar; são estes sujeitos que se inserem nas teias da Internet e do discurso, produzindo sentidos sobre a biblioteca, a partir da exterioridade que os sustentam. Assim sendo, recorremos aos resultados da quarta edição da "Pesquisa sobre o Uso das Tecnologias da Informação e da Comunicação no Brasil - TIC Domicílios", que foi realizada entre os meses de setembro e novembro de 2008, em todo o território nacional, pelo Centro de Estudos sobre as Tecnologias da Informação e da Comunicação no Brasil (CETIC.br), do Núcleo de Informação e Coordenação do Ponto BR (NIC.br), braço executivo do Comitê Gestor da Internet. Segundo tais índices, o nível educacional, assim como a idade, classe social e a renda 
são fatores determinantes para que o sujeito possa pertencer, ou não, à comunidade dos infoincluídos, ter as chaves para entrar ou ser barrado nos portões do ciberespaço:

O perfil do uso do computador e da Internet no país é muito semelhante com relação às variáveis sociodemográficas. Conforme a renda, a classe social e o grau de escolaridade aumentam, maior é a proporção de usuários das tecnologias acima mencionadas. A proporção de usuários de Internet chega a $83 \%$ no nível superior e somente a $7 \%$ entre os analfabetos e pessoas que têm somente educação infantil. No que tange à renda, nota-se que, na faixa de até um salário mínimo, o percentual de usuários de Internet é de 10\%, contra $81 \%$ de usuários de Internet na faixa de dez ou mais salários mínimos. A diferenciação por classe social guarda a maior discrepância entre suas categorias, na medida em que há uma diferença de 76 pontos percentuais entre a classe A (89\%) e as classes D e E (13\%). As análises por faixa etária mostram que os mais jovens continuam a ser os usuários mais assíduos da rede mundial de computadores. Na faixa de dez a 15 anos, mais da metade dos entrevistados, 53\%, declarou ter navegado na web nos últimos três meses. Na faixa entre 16 e 24 anos, a proporção de usuários da Internet é ainda maior: $61 \%$. Porém, na faixa entre 45 e 59 anos, somente $13 \%$ dos respondentes utilizaram a Internet nos três meses anteriores à pesquisa, e, na faixa de 60 anos ou mais, o número de usuários foi de 2\%. (COMITÊ GESTOR DA INTERNET NO BRASIL, 2009, p. 95)

Marcamos que o acesso à rede também é desigual no que diz respeito às diferentes regiões do país. Assim, temos que "o acesso à Internet está presente em 25\% dos domicílios da Região Sudeste e cerca de $20 \%$ nos domicílios das Regiões Sul e Centro-Oeste. Nas Regiões Norte e Nordeste, a proporção de domicílios com acesso à rede não ultrapassa 7\%." (COMITÊ GESTOR DA INTERNET NO BRASIL, 2009, p. 91). Nas áreas rurais brasileiras também são encontradas as menores taxas de acesso às TICs (tecnologias de informação e comunicação), em parte devido à pouca ou nenhuma infra-estrutura para domicílios e centros públicos de acesso gratuito ou pago à Internet (telecentros e, principalmente, as lanhouses, que ganham destaque nas áreas urbanas, onde são, para muitos, as únicas opções de acesso aos computadores e à rede).

Os centros de acesso público são importantes em um panorama marcado por baixos índices de presença de computadores em residências, visto que apenas: "um quarto dos domicílios brasileiros (25\%) possui computadores, independentemente do tipo de equipamento considerado" (COMITÊ GESTOR DA INTERNET NO BRASIL, 2009, p. 90). Um dado interessante aponta que, dentre os lares brasileiros sem computador, o segundo motivo mais citado como barreira à posse do equipamento, com 34\% das menções, foi "não tenho necessidade/ interesse", antecedido pelo "custo" e seguido por "falta de habilidade". (COMITÊ GESTOR DA INTERNET NO BRASIL, 2009). Essa questão da falta de interesse 
leva-nos a desconstruir os sentidos de que navegar na Internet, fazer parte do seleto grupo de infoincluídos seria um desejo unânime, reconhecido como fundamental por todos.

Tal como estamos argumentando, o ciberespaço não pode ser visto sob a ótica da totalidade, já que não permite a livre circulação de todos aqueles que o imaginarizam como objeto de sonho (e consumo) e deixa de fora uma grande parcela que não compartilha dessas aspirações, ou até mesmo desconhece a possibilidade de tê-las, ignorando a existência dessa esfera virtualizada que faz parte de um conjunto de saberes restritos e não distribuídos igualitariamente. Estas discrepâncias são, por muitas vezes, interditadas quando se discursiviza o tema, assim como são silenciados os sentidos e sujeitos que não podem estar na rede. Segundo Romão (2004a, p. 44),

há um silenciamento permanente de sentidos e de sujeitos, que não falam na rede e que não estão lá, fazendo circular os sentidos de sua exclusão. Assim, há mais silêncio do que memória na textualidade eletrônica. Silêncio construído pela interdição de condições materiais que impedem o acesso e o ato de dizer, silêncio como mecanismo que exclui sistematicamente aqueles que não podem estar lá.

Destacamos a importância de refletir sobre estes movimentos de interdição, restrição do acesso à rede, buscando compreendê-los de forma mais ampla e crítica, a fim de que os computadores e a Internet convertam-se em ferramentas mais democráticas, abrangentes quanto à circulação de sujeitos e discursos, e não sejam alvo de ações políticas que pouco contribuem para que isto ocorra, ao lidarem com a questão de forma restrita e/ou assistencialista. É relevante observarmos que os conhecimentos, recursos financeiros e materiais que foram citados são essenciais para que haja a inclusão dos sujeitos na rede; entretanto, há ainda condições de outra ordem tão necessárias quanto, das quais falaremos na última seção deste capítulo. Por ora, é importante ressaltarmos que, apesar da acentuada desigualdade que acabamos de assinalar, enraizada no terreno político-ideológico, a porcentagem de acesso aos computadores e à Internet vem aumentando nos últimos anos. Para citarmos mais alguns dados, apontamos que "no período de 2005 a 2008, verificou-se um crescimento médio anual de aproximadamente $15 \%$ na proporção de usuários de Internet e, no uso do computador, esse crescimento é um pouco inferior" (COMITÊ GESTOR DA INTERNET NO BRASIL, 2009, p. 146). Tais números mais positivos delineiam sentidos mais otimistas acerca das recentes TICs e seus aspectos técnicos.

Considerada por Manguel (2006, p. 264) como “o emblema de nossa sede de onipresença", a Web e suas inúmeras potencialidades alimentam a já mencionada ilusão de (ainda que no futuro) poder alcançar a universalidade. A crença nesta possibilidade vem 
acompanhada de grande euforia e ansiedade, não raro desprovidas de uma reflexão mais apurada acerca das particularidades e das condições sócio-histórico-ideológicas que permitiriam tais desdobramentos. Referindo-se à rede eletrônica, Wolton (2003, p.108-109) afirma que "nunca um sistema técnico criou tanto a sua própria legitimidade suprimindo de um só golpe as realidades do poder, as desigualdades, as mentiras e as relações de força que desde sempre cercam a informação"; o que levou a uma glamourização da Internet e outras TICs, a uma visão irrealista das condições pelas quais tais tecnologias funcionam e impactam os sujeitos. (SORJ, 2003).

Estes sentidos utópicos atribuídos às redes eletrônicas são acompanhados, muitas vezes, pela credibilidade conferida aos discursos circulantes no ciberespaço, convertendo a performance técnica em garantia de veracidade dos conteúdos. (WOLTON, 2003). Deste modo, esses já-ditos cristalizados, revelam uma super-valorização das capacidades técnicas, atribuindo-lhes poder absoluto e confiança quase inabalável. Ressaltamos que uma série de estudos privilegiam esse aspecto tecnológico da rede eletrônica, de forma não apenas a exaltála, mas também criticá-la, como nos mostra Castells (2003a, p. 8):

Algumas vezes isso assumia a forma de profecias futurológicas baseadas na
extrapolação simplista de consequências sociais das maravilhas tecnológicas
que emergem da ciência e da engenharia; outras vezes, aparece como
distopias críticas, denunciando os efeitos supostamente alienantes da Internet
antes mesmo de praticá-la.

Entre utopias e distopias a Internet é significada de diversas maneiras, constituindo uma rede de sentidos discrepantes e constantemente reformulados por meio de "batalhas" travadas entre os teóricos que, ao ocuparem diferentes posições-sujeito, enunciam sobre a Internet sustentando discursos que não são propriamente novos, visto que já foram associados a outras tecnologias:

Estamos hoje no fogo cruzado entre intelectuais que associam uma postura 'crítica' a uma visão negativa da tecnologia (por exemplo, Virilio, Baudrillard, Shapiro, Postman) e aqueles dito utópicos, que vêem nas novas tecnologias um enorme potencial emancipatório, fonte de criação de inteligentes coletivos, de resgate comunitário e de enriquecimento do processo de aprendizagem (Negroponte, Lévy, De Rosnay, Rheingold). (LEMOS, 2007, p.247)

Segundo Castells (2003a), a elasticidade da Internet intensifica as tendências contraditórias presentes em nosso mundo, o que nos leva a concordar com Romão (2004b, p.74), quando ela diz que a Internet "abre espaço para se pensar a emergência de novas posições-sujeito, de discursos e contra-discursos, de sentidos de dominação e resistência, que 
se enrodilham em espirais movimentadas". Acerca dos discursos e contra-discursos sobre a rede, Santaella (2003) nos fala sobre os eufóricos e suas fantasias de um (ciber)espaço despojado das formas tradicionais de poder ou organização sociais e, também, sobre os chamados disfóricos, que se apressaram em atribuir ao ciberespaço, discursos já gastos e excessivamente empregados na crítica da cultura de massas, indústria cultural e sociedade instrumental, ignorando-se, assim, suas particularidades.

Por fim, cabe ressaltarmos que, conforme nos diz Lemos (2007), as tecnologias sempre despertaram medo e fascinação, amor e ódio, suscitando posições extremadas que acabaram por polarizar os sentidos sobre a cibercultura. Tentativas de instaurar um consenso, uma terceira via alternativa, como a do movimento tecnorealista, malograram; persiste a indefinição. Essa ausência de contornos nítidos e de certezas absolutas pode ser observada no emprego, muitas vezes confuso, de conceitos inerentes à cibercultura, tais como "Internet", "web", "ciberespaço", "hipertexto", etc. Passemos agora para algumas considerações acerca destes termos, visto que os mesmos são largamente utilizados neste trabalho.

\subsection{Desenrolando os fios da rede: notas sobre a materialidade do (hiper)texto digital}

O texto, ao fazer-se, é semelhante a uma renda valenciana que nasce diante de nós dos dedos da rendeira: cada sequência espera, como um bilro provisoriamente inativo, enquanto seu vizinho trabalha; em seguida, quando chega sua vez, a mão retoma o fio; e, à medida que o desenho se constitui, cada fio marca sua ação com um alfinete, que retém e desloca o desenho pouco a pouco. (BARTHES, 1992, p. 181)

Assim como sob os dedos de uma rendeira faz-se um delicado bordado de fios entretecidos em movimentos de retenção e deslocamento, é a partir dos fios de sentidos urdidos nas tramas do discurso, entre o mesmo e o diferente, que se constroem os (hiper)textos digitais, postos em circulação pelos sujeitos na rede. Sendo assim, para podermos desenrolar alguns destes fios com os quais se tecem os discursos na rede eletrônica é preciso investigar como se constitui a malha digital, o imbricamento de nós na materialidade dos (hiper)textos digitais, que viabilizam a topologia labiríntica do ciberespaço e instauram uma forma de dizer na rede, que não é igual àquela como se enuncia no impresso; para tanto, passearemos por alguns conceitos caros ao nosso trabalho, começando pela própria noção de rede. 
O termo "rede" pode evocar sentidos muito diversos: a rede entrelaçada de fios que constituem um tecido; aquela usada para obtermos o alimento, capturar os peixes e outros animais; a que serve de proteção contra quedas e aquela na qual descansamos; a que nos engana quando caímos nela; aquela que divide os lados adversários em um jogo, como o tênis; a rede de transporte, de comunicação, de lojas; rede de esgoto, de energia elétrica, de água; rede de pessoas; enfim, seja unindo, sustentando ou até separando, a rede sempre esteve presente na vida do homem, o que é confirmado por Castells (2003a, p.7): "uma rede é um conjunto de nós interconectados. A formação de redes é uma prática humana muito antiga, mas as redes ganharam vida nova em nosso tempo transformando-se em redes de informação energizadas pela Internet". Deste modo, através das tecnologias geradas no âmbito das telecomunicações, computação e eletrônica, foi possível o desenvolvimento das redes de computadores, chamadas redes eletrônicas. Dentre as muitas redes existentes, a Internet ganha destaque, integrando várias delas e oferecendo diversos serviços e produtos de informação. (VARGAS, 1994).

Podemos inferir, então, que os sentidos sobre rede que circulam atualmente são sustentados principalmente pelo discurso da informática, que ocupa um lugar de destaque dentre os saberes em tempos ditos pós-modernos, fazendo com que pareça natural a relação estabelecida entre rede e Internet, escamoteando outros sentidos circulantes em contextos diferentes. Ao ter acesso a esse saber e valer-se dele para enunciar, o sujeito tem sua fala revestida da credibilidade e prestígio que envolvem as mais recentes técnicas e tecnologias. Sendo assim, no contexto da informática, entende-se que a rede é o "conjunto de computadores, terminais e demais equipamentos periféricos interligados por linhas de comunicação que lhes permitem intercambiar informações entre si” (RAMAL, 2002, p.136). É essa aliança entre computadores e redes que faz com que se crie, distribua e receba conteúdos audiovisuais, combinando uma variedade de funções de outras mídias em um único equipamento (SANTAELLA, 2003). Cabe observamos também que, com a rede disponibilizada:

tem-se, pela primeira vez na história humana, uma cadeia mundialmente interconectada de máquinas que se comunicam entre si ao mesmo tempo e de diferentes lugares. Aparelhos eletrônicos são interligados continuamente dentro de uma tipologia não-linear, labiríntica e diversificada de endereços, onde desfilam áreas de lazer, compras, estudo, entretenimento, pesquisa, conversa etc. Esse circuito febril de sites, páginas e endereços eletrônicos modifica substancialmente as noções de tempo e espaço. (ROMÃO, 2004a, p.41) 
Por conseguinte, em meio ao trânsito incessante de sentidos e sujeitos que navegam por entre os nós da rede sem a presença de um centro controlador, a Internet é construída não através de princípios hierárquicos, mas "como se uma grande teia na forma do globo envolvesse a terra inteira, sem bordas nem centros" (SANTAELLA, 2004, p. 38). Temos, assim, que o centro pode estar em toda parte e, ao mesmo tempo, em lugar nenhum, fazendo com que "o caráter acêntrico e policêntrico se conjuguem simultaneamente" (LEÃO, 2005, p. 71). Chamamos a atenção para o caráter plural dessa grande teia da Internet, que é composta por milhares de sub-redes, sendo a mais famosa delas a World Wide Web (WWW), conhecida geralmente apenas por Web. Conforme nos diz Leão (2005, p.140), "o que faz da Web uma teia, uma rede na qual uma complexa malha de informações se interligam, é a própria tecnologia hipertextual que permite os elos entre os pontos diversos. Cada página, cada site, traz em si o potencial de se intercomunicar com todos os outros pontos da rede", propiciando o acesso a textos, músicas, sons, animações, filmes, etc.

Cabe ressaltarmos que uma série de recursos tecnológicos disponíveis neste espaço ciber, como o hipertexto digital, fizeram com que a Web seja a parte multimídia e também a mais popular da Internet, a que permite a visualização e a navegação por entre as páginas, as chamadas Home Page, (BLATTMANN; FRAGOSO, 2003), tendo sido importantes também para aproximar os computadores dos não-especialistas em informática. A emergência dessa porção da Internet a qual chamamos de Web deu-se em 1991, quando Tim-Berners-Lee e outros pesquisadores, que trabalhavam para um laboratório de pesquisas europeu sediado na Suíça (CERN), desenvolveram-na, valendo-se do princípio do hipertexto e baseando-se em uma interface gráfica (LEÃO, 2005), instituindo-se assim uma outra relação com o computador e, consequentemente, outras formas de produção de sentidos a partir de suas redes. Segundo Cébrian (1999), após a invenção do hipertexto e o subsequente aparecimento do primeiro navegador, que interpretaria a linguagem da rede e a traduziria de forma inteligível para o sujeito-navegador de páginas eletrônicas, a comunicação foi facilitada, levando a Internet a ocupar outros espaços para além das fronteiras acadêmicas, acelerando, assim, o crescimento desordenado desta "rede de redes", que se assemelha a uma teia de aranha e se apresenta, segundo Castells (2003b, p. 431), como a "espinha dorsal da comunicação global mediada por computadores."

Portanto, conforme nos conta Castells (2003a), ao longo da década de 1990, a WWW contribui para que a Internet se expandisse por várias regiões do globo, nas quais ela foi privatizada (a partir de 1995, ano marcado pela criação do navegador da Microsoft- o Internet Explorer) e provida de uma arquitetura técnica aberta, viabilizando a interconexão entre as 
redes de computadores e o reconhecimento do papel de destaque que, a partir daí, passou a ocupar de maneira cada vez mais incisiva na sociedade. Deste modo:

Embora a Internet tivesse começado na mente dos cientistas da computação no início da década de 1960, uma rede de comunicações por computadores tivesse sido formada em 1969, e comunidades dispersas de computação reunindo cientistas e hackers tivessem brotado desde o final da década de 1970, para a maioria das pessoas, para os empresários e para a sociedade em geral, foi em 1995 que ela nasceu. (CASTELLS, 2003a, p.19)

Vale ressaltarmos que as origens da Internet remontam à Arpanet, uma rede de computadores, criada pelo Departamento de Defesa dos Estados Unidos, através de sua Advanced Research Projects Agency (ARPA), em setembro de 1969. O objetivo da ARPA era mobilizar recursos de pesquisas universitárias para alcançar a superioridade tecnológica militar em relação à União Soviética, havia a esperança de que os cientistas, estimulados pela sua relativa autonomia, produzissem algo que beneficiasse os militares e também a economia dos Estados Unidos; assim sendo, as disputas entre os dois países envolvidos na Guerra Fria forneceram um contexto em que havia apoio popular e governamental para o investimento em ciência e tecnologia de ponta. É importante observarmos que, ainda que a missão dos cientistas da computação que desenvolveram a Arpanet pouco tinha a ver com estratégia militar, o apoio do Departamento de Defesa foi fundamental, pois disponibilizou os recursos necessários para construir uma rede de computadores e para projetar as tecnologias adequadas. Os primeiros nós dessa rede estavam em duas universidades estadunidenses (Universidades da Califórnia e de Utah) e no SRI (Stanford Research Institute). (CASTELLS, 2003a).

Durante a década de 1980, a Arpanet foi ligada a outras redes não apenas militares, como a CSNET (uma rede civil que conectou os departamentos de ciência), criando-se, assim, uma rede global de redes; cabe observamos que isto foi possível através de protocolos de comunicação padronizados (destaque para o TCP/IP) que permitiram a troca de informações entre as diferentes redes de computadores. Entretanto, apesar da expansão, até o início da década de 1980, poucas pessoas fora dos campos militar e acadêmico tinham acesso à rede. Isto mudou em 1985, quando foi criada, pela National Science Foundation, a NSFNET que, mais tarde (em 1990), substituiu a obsoleta ARPANET e foi a base do que logo seria a Internet, libertando-a de seu domínio militar; assim sendo, esta rede impulsionou o crescimento da Internet, na medida em que serviu de suporte para uma série de redes regionais dos Estados Unidos. O controle da Net pela NSF durou pouco tempo, visto que, como já foi dito, em 1995 foi iniciada a privatização das redes. (WERTHEIM, 2001). 
Marcamos que a Arpanet não foi a única fonte do formato que a Internet tem hoje, visto que ela também foi influenciada por criações de estudantes e programadores, as quais foram liberadas para o domínio público. Como exemplo, citamos o desenvolvimento do MODEM, que era um programa que permitia a transferência de arquivos entre computadores pessoais, e do Computer Bulletin Board System, que possibilitava aos computadores armazenar e transmitir mensagens. Outra tendência importante para formação das redes de computadores veio da comunidade dos usuários do UNIX (sistema operacional que foi desenvolvido pelos Laboratórios Bell e liberado para as universidades em 1974), composta por estudantes que projetaram um programa de comunicação entre os computadores UNIX, cuja versão aperfeiçoada foi distribuída gratuitamente, permitindo a formação de redes de comunicação entre computadores (a Usenet News) fora do controle da Arpanet. Em 1980, quando a Usenet News chegou à Universidade da Califórnia em Berkely (que era um nó da Arpanet), um grupo de estudantes desenvolveu um programa para ligar estas duas redes, que se fundiram gradualmente, fazendo com que várias redes de computadores pudessem se comunicar, congregando na forma da Internet. (CASTELLS, 2003a). Ainda segundo o autor, ressaltamos outro desenvolvimento notável, que foi resultante da tradição dos usuários do UNIX e corresponde ao movimento de fonte aberta, uma tentativa de manter livre o acesso à informação relativa a sistemas de software. Tais movimentos que almejavam a liberdade na Internet levaram à criação da Free Software Foundation (que propôs a substituição do copyright pelo copyleft, através do qual qualquer pessoa que usasse um software gratuito deveria distribuir pela Net o seu código aperfeiçoado) e de sistemas operacionais gratuitos (o GNU, que foi disponibilizado na Net sob uma licença que permitia o seu uso se fosse respeitada a cláusula copyleft, e o Linux, que foi disponibilizado a usuários incitados a aperfeiçoá-lo). (CASTELLS, 2003a).

Posto isto, inferimos que o desenvolvimento da Internet deve muito às comunidades estudantis de hackers que, na cultura da liberdade individual que floresceu nos campi universitários ao longo das décadas de 1960 e 1970, buscaram a inovação tecnológica, de forma cooperativa e através dos recursos disponibilizados pelos centros acadêmicos de pesquisa. Segundo Castells (2003a, p. 42), animados pelo prazer da descoberta, da "liberdade para criar, liberdade para apropriar todo conhecimento disponível e liberdade para redistribuir esse conhecimento sob qualquer forma ou por qualquer canal", os hackers das comunidades acadêmicas integraram uma série de redes alternativas, que desestruturaram o controle governamental e foram decisivas para a difusão da comunicação eletrônica pelo mundo. 
Observamos que o surgimento e disseminação da Internet - essa tecnologia arrojada e demandante de robustos investimentos e estrutura - não poderiam ocorrer em um mundo dos negócios que não tolera riscos (no qual a Internet só entrou nos anos 1990), mas sim no restrito âmbito das poderosas instituições governamentais e do saber, instalando a dualidade entre a busca do controle pelas primeiras e a da liberdade pelas segundas. Assim, é importante analisarmos a Internet não apenas sob a sua perspectiva técnica, mas também sócio-histórica e ideológica, observando a tensa luta pelo poder de dizer, saber e percorrer suas redes, que marcou (e ainda marca) sua origem no período da Guerra Fria, tendo como palco as esferas política e científica, que foram responsáveis por sua legitimação e expansão, pelas quais também passou os Estados Unidos: a emergente potência mundial que abarcou as redes eletrônicas. Assim sendo, a origem ilustre da Internet indicia as relações de força que, conforme já abordamos, conferem-lhe prestígio e, ao mesmo tempo, impedem ou dificultam o acesso da maioria dos sujeitos às suas redes; situação esta que, no que diz respeito ao Brasil, apesar de ter sido atenuada nos últimos anos, está longe de ser totalmente resolvida.

Por fim, apontamos que, no contexto brasileiro, a história da Internet começou apenas no final dos anos 1980, com a ligação entre algumas instituições brasileiras e estadunidenses, em 1988. No ano seguinte, foi lançado o importante projeto de uma rede com abrangência nacional, a Rede Nacional de Pesquisa (RNP), gerenciada pelo Conselho Nacional de Desenvolvimento Científico e Tecnológico (CNPQ). (VARGAS, 1994). A partir daí, e especialmente após 1995, as redes eletrônicas expandiram-se do âmbito acadêmico e nacional em direção ao global e comercial; porém, isto ainda não ocorreu de forma tão abrangente em relação ao seu acesso, conforme foi mostrado na seção anterior.

Observamos que, para que o sujeito possa velejar pela web, este mar revolto e instável, são necessários “links, lexias hipertextuais que induzem a navegação de informação em informação, de site em site, de país em país através de softwares como o antigo Mosaic ou os atuais Netscape, Explorer ou mesmo o magrinho Opera” (LEMOS, 2007, p.119). Assim, o hipertexto é materializado na rede a cada clique, a cada instante, "numa reconversão ininterrupta de sentidos de subjetividades que fluem, se misturam e se dinamizam mutuamente, integrando a inteligência coletiva constituída de uma multiplicidade de vozes, de culturas e de pensamentos." (RAMAL, 2002, p.141). Construído por muitas mãos, aberto a incontáveis links e sentidos possíveis, o hipertexto potencializa, segundo Lemos (2007), a subversão das categorias típicas da cultura linear, combinando informações textuais com sons e imagens animadas ou fixas, constituindo-se como uma obra com várias entradas disponíveis para o sujeito leitor-navegador. Na visão de Lévy (1999, p. 127), "hipertexto é um texto em 
formato digital, reconfigurável e fluido. Ele é composto por blocos elementares ligados por links que podem ser explorados em tempo real na tela". Em outras palavras, o hipertexto é “constituído de nós (os elementos de informação, parágrafos, páginas, imagens, sequências musicais etc.) e de ligações entre esses nós (referências, notas, indicadores, 'botões’ que efetuam a passagem de um nó a outro).” (LÉVY, 1996, p. 44).

Como exemplo desses novos recursos e possibilidades de relação com a linguagem, que nos são oferecidos pelo hipertexto digital, apresentamos a Biblioteca Escolar Digital ${ }^{2}$, elaborada pela Fundación Germán Sánchez Ruipére, uma instituição espanhola sem fins lucrativos. Essa biblioteca é dividida em três ambientes, dedicados à educação infantil (de 3 a 5 anos), primária e aos professores; todos eles disponibilizam uma série de recursos. Apresentaremos a seguir a página eletrônica inicial desta biblioteca e, em sequência, as da Biblioteca Escolar Digital Infantil e Biblioteca Escolar Digital Primaria, que lhe constituem:

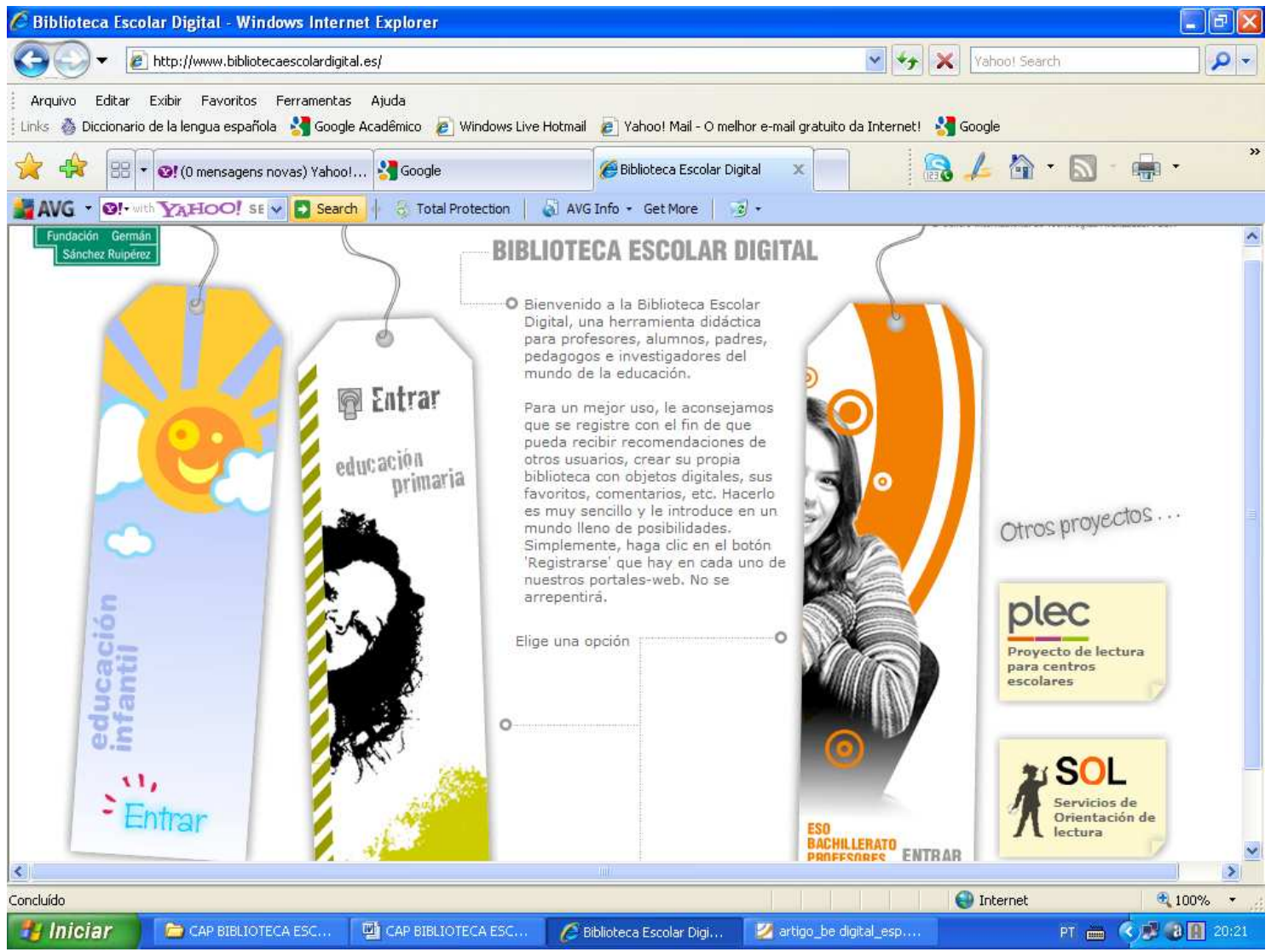

\footnotetext{
${ }^{2}$ Disponível em: <http://www.bibliotecaescolardigital.es/bidig_primaria/index.php>. Acesso em: 22 dez. 2009.
} 


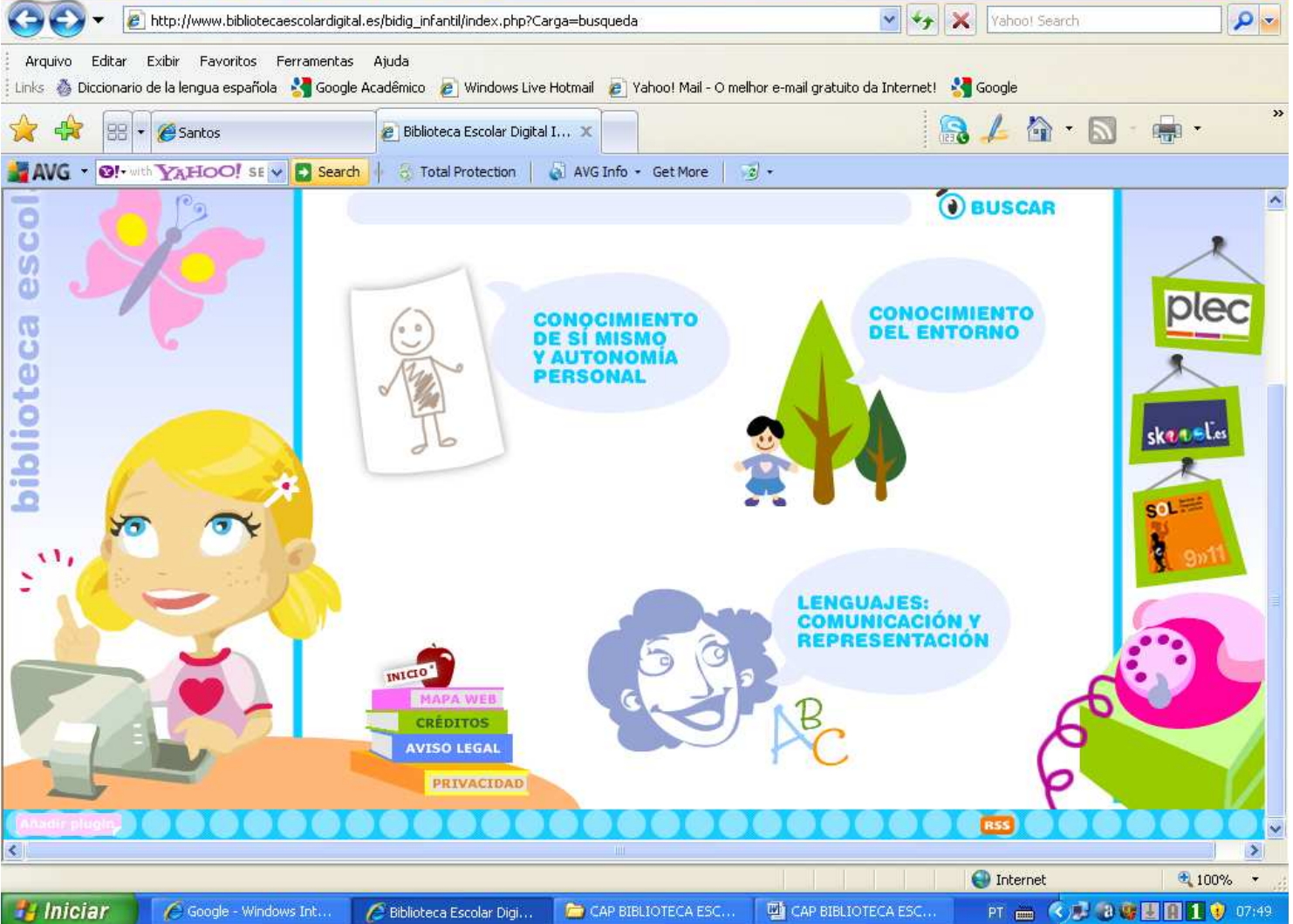

Arquivo Editar Exibir Favoritos Ferramentas Ajuda

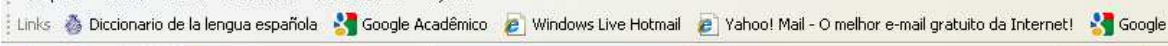

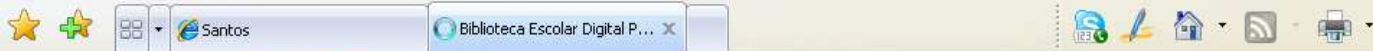

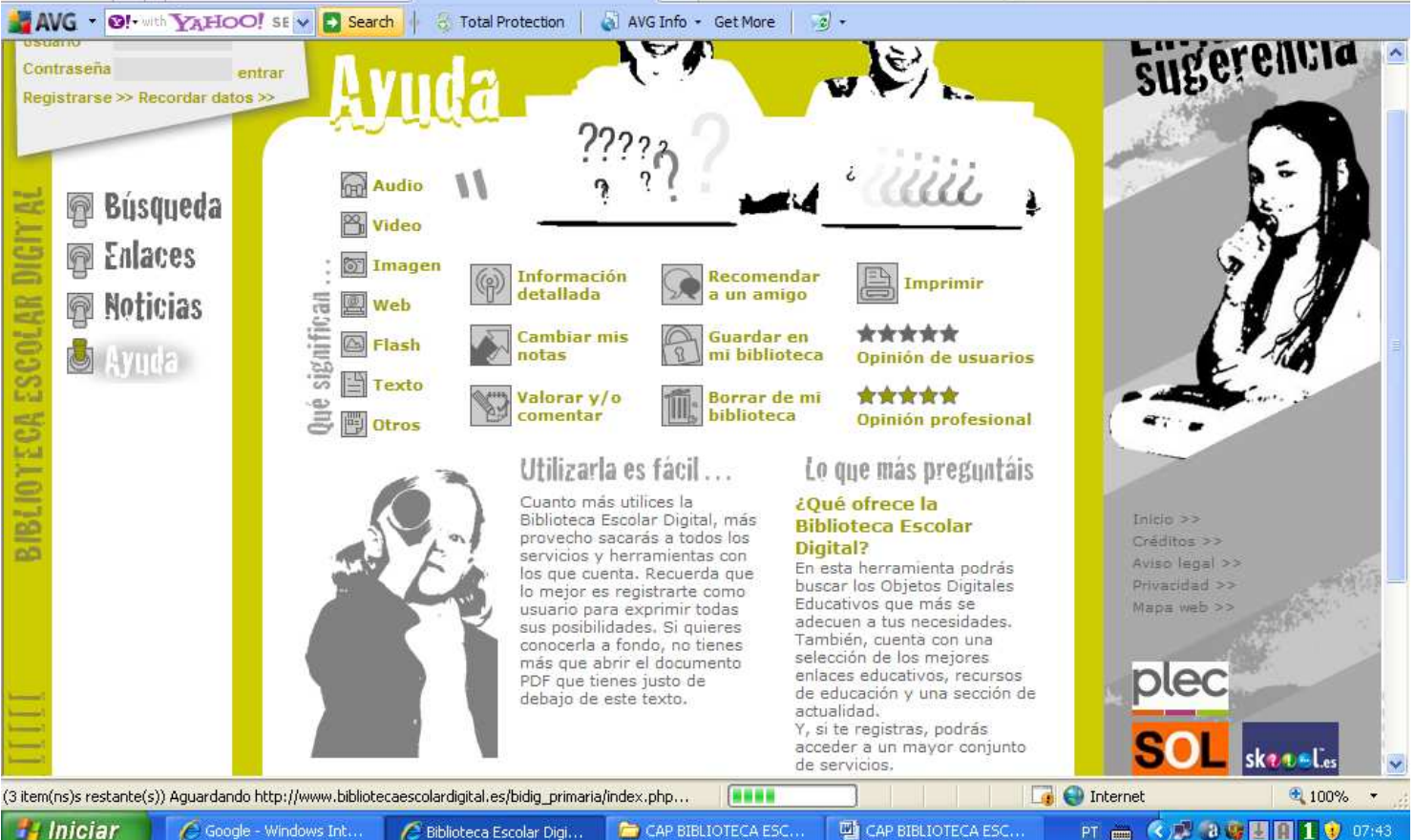


Nesses espaços discursivos denominados links, observamos a presença de diversas maneiras de lidar com a linguagem e o conhecimento, possibilitando aos sujeitos ocuparem a posição de leitor e autor, produzirem sentidos acerca de si mesmo e do mundo, compartilhando-os com outros sujeitos, através de ferramentas como a que permite fazer e acessar comentários e recomendações sobre os documentos encontrados no sistema, enviar e receber colaborações em forma de artigos. É disponibilizada também, além dos documentos digitalizados, uma série de links para sites, jogos e atividades educativos, que convidam o sujeito a participar ativamente de sua realização, como o cuento interactivo, em que, a partir de diversas opções, pode-se escolher algumas para montar uma história, apresentada por meio de imagens e palavras. Além disso, pode-se constituir a sua própria biblioteca, com os recursos selecionados na Biblioteca Escolar Digital, inaugurando assim, um novo ambiente virtual. Os recursos apresentados são viabilizados a partir da tecnologia do hipertexto, confirmando a sua crescente importância para a área de educação, conforme nos conta Pereira (1998, p.35):

é na atividade educacional que o hipertexto tem uma participação essencial. São inúmeras as possibilidade de sua aplicação na área do ensino/aprendizagem que, certamente, quando bem utilizadas, proporcionarão aos usuários desta nova tecnologia um avanço ilimitado na aquisição de conhecimentos. Os recursos advindos do uso de sons, imagens e animação associados aos textos ampliam e facilitam a obtenção de informações de uma forma completamente nova.

É interessante observarmos que, apesar de ser frequentemente relacionado à Internet e ao universo digital, o hipertexto não está restrito ao seu âmbito, visto que: "consiste numa forma organizacional que tanto pode ser concebida para o papel como para ambientes digitais" (RAMAL, 2002, p. 87). Deste modo, os índices, sumário, notas de rodapé e outros recursos que quebram a linearidade do tex to também podem ser considerados hipertextos, mas é apenas na Internet que podem ser concretizados alguns aspectos como, por exemplo, a remissão do leitor a outros textos, e não necessariamente a partes de um mesmo texto (SILVA, E., 2003), “a conexão imediata, a comparação de trechos de textos na mesma tela e o 'mergulho' dos diversos aprofundamentos de um tema, como se o texto tivesse camadas, dimensões ou planos.” (RAMAL, 2002, p. 87-88). Essas inúmeras possibilidades de desdobramento dos textos permitem, para Lemos (2007), a falência dos significados de margem, hierarquia e linearidade, conforme foi anunciado por Barthes, Derrida e Foucault. Ainda segundo o autor, a isso podemos chamar de ciberespaço: a este mundo operante que descrevemos até aqui, interligado por ícones, portais, sítios e home pages, nos quais, segundo 
Lévy (1996), estão sendo misturadas as noções de unidade, de identidade e localização; tratase, assim, de um espaço eletrônico sem fronteiras, ocupado por sites- pátrias autodefinidasque não o limitam nem o possuem, sendo como água vertida em água (MANGUEL, 2006).

Retomamos aqui o uso social do termo ciberespaço que foi usado pela primeira vez em 1984, no romance de Willian Gibson intitulado Neuromancer, e, na atualidade, refere-se frequentemente ao espaço criado pelo computador e pelas redes de informação. (LEÃO, 2005). Entretanto, conforme nos conta Leão (2004, p.9), o ciberespaço camaleônico é mais do que isso, englobando "das redes de computadores interligadas no planeta (incluindo seus documentos, programas e dados); as pessoas, grupos e instituições que participam dessa interconectividade e, finalmente, o espaço (virtual, social, informacional, cultural e comunitário) que emerge das inter-relações homens-documentos-máquinas.” E essa segunda denominação nos parece mais interessante para observarmos o site acima apresentado, visto que na página eletrônica as inter-relações de sujeitos e sentidos estão postas em discurso.

Compreendemos, pois, que o ciberespaço não apenas em relação a sua estrutura, como um mero repositório, mas como um espaço discursivo plural e movimentado, o qual "abarca não apenas a armazenagem e circulação dos discursos, mas também a produção, as formas de organização e articulação, além da recepção" (MITTMANN, 2008, p. 113-114). Consideramos este espaço ciber a partir das relações que nele se dão, entre discursos e sujeitos, tomando-o como "um lugar de encontros e de aventuras, terreno de conflitos mundiais, nova fronteira econômica e cultural [...] designa menos os novos suportes de informação do que os modos originais de criação, de navegação no conhecimento e de relação social por ele propiciados." (LÉVY,1998, p.104).

Por fim, inferimos que, em meio às relações colocadas em jogo (e tensão) no ciberespaço, o sujeito pode participar da (re)construção dos sentidos empreendida em cada nó deste "hipertexto mundial interativo, onde cada um pode adicionar, retirar e modificar partes dessa estrutura telemática, como um texto vivo, um organismo auto-organizante." (LEMOS, 2007, p.123). Após abordarmos conceitos importantes pra a compreensão do nosso tema e apresentarmos algumas pistas que nos levaram a refletir sobre a topologia da rede eletrônica, iremos tecer algumas considerações sobre os movimentos do sujeito-navegador pelos mares da Internet. 


\subsection{Nas redes da Internet: discursos e sujeitos em movimento}

As palavras, se não o sabe, movem-se muito, mudam de um dia para o outro, são instáveis como sombras, sombras elas mesmas, que tanto estão como deixaram de estar, bolas de sabão. (SARAMAGO, 2005, p. 109)

Como analistas do discurso, consideramos que ele não corresponde à materialidade de palavras fixas, imutáveis, visto que estas "mudam de sentido segundo as posições daqueles que as empregam." (ORLANDI, 2003b, p. 42-43) e o contexto no qual são enunciadas, compondo a trama de um discurso sempre em (re)construção, que se mostra instável e provisório; como as sombras, que mudam de lugar e tamanho ao sabor da claridade, ou as bolas de sabão, que se movem refletindo múltiplos efeitos de cor, dependendo da maneira como a luz as atravessa, até desmancharem-se no ar. Não é apenas a fluida materialidade virtual que é posta, pelos sujeitos-navegadores, em contínuo deslocamento, não são apenas os links e sites que, ao serem navegados, podem ser desativados ou modificados a cada segundo, mas também os discursos que neles se sustentam e podem ser atualizados ou esquecidos, conforme o modo como eles se trançam com a história, a memória e a ideologia, que afetam a produção e circulação dos sentidos na rede. Isso porque, por ter o movimento e a instabilidade como constitutivos, "todo enunciado é intrinsecamente suscetível de tornar-se outro, diferente de si mesmo, se deslocar discursivamente de seu sentido para derivar para um outro" (PÊCHEUX, 2002, p. 53), compondo uma série de pontos de deriva possíveis, que oferecem um lugar de interpretação, em meio à estrutura aberta, plural e descentralizada das redes eletrônicas, onde "a única constância parece ser a da inevitabilidade das ressignificações, umas sobre as outras, ou seja, o inconstante.” (MITTMANN, 2008, p. 115)

Essa inconstância faz com que o sujeito-navegador percorra "os nós da rede de uma forma totalmente imprevisível, muitas vezes até para ele próprio" (LEÃO, 2005, p.57), não havendo, assim, caminhos pré-definidos a serem seguidos, na medida em que, segundo Castells (2003a, p. 171), “cada nó está conectado a todos os outros através de uma miríade de rotas possíveis". Por conseguinte, o espaço ciber se reestrutura e reconfigura a cada passo, não sendo possível termos uma visão aérea deste ambiente movediço, que se abre quando o sujeito-navegador emerge na rede e se movimenta de maneira indefinida, "equilibrando-se entre a desorientação mais turva e a iluminação mais cintilante". (SANTAELLA, 2004, p. 103). Ao navegar por entre links e arquivos sem linearidade lógica, "o sujeito passa de um texto jornalístico a uma receita de bolo, de uma rede de amigos a outra de serviços, 
construindo-se diversas tramas discursivas que se entrecruzam em um todo desconexo e fragmentado" (FERRAREZI; ROMÃO, 2007, p. 260). Delineia-se, assim, uma tessitura textual que desenha uma teia de associações, caminhos limitados pelo trajeto percorrido pelo sujeito em seus movimentos pelo labirinto virtual, os quais deixam suas marcas ao longo do percurso que, para Ramal (2002, p.84) é "tecido de maneira original e única pelo leitor cibernético."

A respeito das maneiras de ler na materialidade virtual, é importante ressaltarmos primeiro que toda leitura é um gesto de atribuição de sentidos, que depende da posição do sujeito e do modo como a ideologia o interpela em sujeito de suas leituras; tal concepção está em consonância com a teoria da Análise do Discurso, pela qual se desconstroem os sentidos de uma leitura única, certa ou natural, que não leva em conta as relações com a exterioridade e o interdiscurso- restrições estas que não cabem em um espaço desterritorializado, que é atravessado freneticamente por várias vozes e discursos, percorrido por um sujeito-leitor em estado de prontidão, que se conecta "entre nós e nexos, num roteiro multilinear, multissequencial e labiríntico que ele próprio ajudou a construir ao interagir com os nós entre palavras, imagens, documentação, músicas, vídeo, etc" (SANTAELLA, 2004, p. 33). A virtualidade da rede parece escancarar a multiplicidade que constitui todo discurso, instalando novas formas de ler e produzir sentidos, de relacionar-se com discursos outros, nos quais se pode intervir, de forma mais ampla. Desse modo, segundo Chartier (1999, p. 92), "levado por uma nova técnica e um novo suporte, o texto pode se oferecer às manipulações do leitor, cujas intervenções não serão reduzidas, como no caso do livro impresso, a insinuar uma escritura manuscrita nos espaços brancos deixados pela impressão tipográfica.” Essas possibilidades de o sujeito-leitor fazer intervenções nos discursos, reordená-los e, deslocá-los implica, muitas vezes, um movimento de recorte, supressões e recolocações que os deslocam de seus contextos e conferem à leitura um caráter descontínuo, pois o sujeito:

busca, a partir de palavras-chave ou rubricas temáticas, o fragmento textual do qual quer apodera-se (um artigo em um periódico, um capitulo em um livro, uma informação em um web site), sem que necessariamente sejam percebidas a identidade e a coerência da totalidade textual que contém esse elemento. Num certo sentido, no mundo digital todas as entidades textuais são como bancos de dados que procuram fragmentos cuja leitura absolutamente não supõe a compreensão ou percepção das obras em sua identidade singular. Assim, quanto à ordem dos discursos, o mundo eletrônico provoca uma tríplice ruptura: propõe uma nova técnica de difusão da escrita, incita uma nova relação com os textos, impõe-lhes uma nova forma de inscrição (CHARTIER, 2002, p.23-24) 
Sendo assim, essa nova forma de inscrição dos discursos no ciberespaço, aos moldes de um patchwork de sentidos múltiplos, permite que o sujeito os leia a partir de qualquer ponto e direção, "do início para o final e/ou do final para o início, vasculhado a partir de outro rastreamento que não aquele que levava em conta o início, meio e final com a leitura iniciada sempre pelo lado esquerdo e com o dedo deslizando em direção à direita e à linha debaixo". (ROMÃO, 2005a, p. 4). Por fim, observamos que essa fragmentação dos discursos e dos gestos de leitura fazem, também, com que os sujeitos possam "escapar", migrar para outras regiões de sentido, desviarem-se da rotas que começaram a percorrer, visto que:

A navegação on-line permite que um trajeto seja interrompido e modificado de direção a qualquer clique, ampliando as chances/ de o leitor escapar por meio de outras páginas eletrônicas e por entre as frestas da imensidão desta teia de conexões. Do interior de um texto, há possibilidade de deslocamento, errância em diversas direções, pois as janelas do ciberespaço se abrem em uma fundura de navegação polidimensional. (ROMÃO, 2004b, p. 72-73)

Posto isto, associamos o sujeito-navegador a um leitor ativo, um construtor de labirintos, "que está a todo momento estabelecendo relações próprias entre diversos caminhos" (LEÃO, 2005, p.16), múltiplas possibilidades de atualização de sentidos, que configuram uma nova forma de ler, a qual pensamos ser mais aberta à polissemia, a um vir-aser constante, visto que a Internet é um espaço que se desdobra e que oferece "oportunidades de leitura em diferentes direções [...] um espaço de informação e interação constituído por uma complexa malha de significados, aos quais o próprio sujeito atribui ordem e entendimento, não sendo apenas espectador". (SILVA, 2006, p. 73). Em meio às diversas possibilidades de interpretação e (re)construção dos discursos, marcamos que a cópia, desmembramento, recomposição ou deslocamentos dos textos digitais sinalizam a tênue fronteira existente entre as posições de sujeito-leitor e autor, o público e o privado, sentidos constituídos por mim e pelo outro, destacando a importância da heterogeneidade dos discursos e do sujeito, o qual "se define agora como sendo a relação entre o 'eu' e o 'outro'. O sujeito é constitutivamente heterogêneo, da mesma forma que o discurso o é." (MUSSALIM, 2001, p. 134). Assim sendo, no fluxo movediço que condiciona o dizer na rede, circulam vozes heterogêneas e justapostas de forma desarranjada, sujeitos errantes que se deslocam entre palavras, imagens e arquivos alheios, mantendo-se sempre em um movimento de avanço ou retorno, no "entre-meio de páginas, links e ícones que o endereçam a outros sítios, a tantas teias intertextuais [...] múltiplas entradas para pisar na voz do outro, diversas janelas para abrir arquivos que, como eu disse anteriormente, já foram previamente escolhidos." (ROMÃO, 2006, p. 309). 
Observamos que esta relação com discursos outros pode envolver tensões e conflitos, que indiciam as relações de força pelas quais se tenta silenciar certas vozes, apagando determinadas regiões de sentido das quais o sujeito se apropria como se fossem suas, ou com as quais ele não se alinha. Essas tentativas de apagar a heterogeneidade são da ordem do inconsciente, do ideológico, pois, assim como os sujeitos não são donos dos seus dizeres e nem os controlam (impossibilidades estas das quais eles inconscientemente se esquecem, através dos esquecimentos de número 1 e 2, que Pêcheux (1997) propôs), eles têm seus movimentos de navegação na rede afetados pelas formações discursivas que os dominam e manifestam as formações ideológicas que os levam a legitimar (ou não) alguns discursos, dentre tantos com os quais se relacionam na virtualidade da rede, que "possibilita essa confusão de vozes, posições e representações nas redes de filiação" (ROMÃO, 2008, p. 96). É importante observarmos que as formações discursivas de que falamos, e dizem respeito à matriz dos sentidos que regula o que pode ou não ser dito nas redes da Internet, são definidas a partir do interdiscurso que fundamenta o dizer, da memória discursiva que, segundo Orlandi (2003b, p. 31), “disponibiliza dizeres que afetam o modo como o sujeito significa em uma situação discursiva dada." Assim sendo:

No entre-meio dos links, a ordem da língua e a ordem da história reclamam o tempo todo que a linguagem seja significada a partir do que não está na tela, mas do que a memória histórica e a memória do dizer cavaram em outros locais, em outros atos de dizer e em outras inscrições sociais dos significantes. (ROMÃO, 2005a, p. 6-7)

Portanto, para o sujeito-navegador da rede, os links, que se remetem uns aos outros e colam-se mutuamente o tempo todo em uma teia de nós e conexões, só fazem e constroem sentidos, se ele tiver acesso à memória e ao arquivo em movimento na rede, posto que o sujeito se inscreve, segundo Romão (2006, p. 307), em "locais que já foram autorizados, previamente lidos e acomodados" por outros sujeitos, movimentando-se na rede do já-dado e traçado, entre nós que já foram atados por outrem, deslocando-se:

permanentemente sem parada, inscrevendo (-se em) ditos nos meandros de dizeres que se apóiam em outros ditos, consumindo (-se) palavras sob as cifras de outras palavras, brincando de enunciar a si mesmo a partir das palavras dos outros, enfim, percorrendo dizeres já inscritos e já propagados e formulando outros. (FERRAREZI; ROMÃO, 2007, p. 259)

Em meio à heterogeneidade, o sujeito percorre, em seus movimentos de navegação, leitura e descobrimento da rede, zonas de memória ressignificadas por outros sujeitos, com as quais ele se relaciona e pode, a partir daí, instalar uma nova discursividade, o diferente, ao 
constituir uma outra forma dos sentidos funcionarem, que é sustentada pelas potencialidades dadas pelo ciberespaço, pela "mutação gerada pela tecnologia digital e consequentemente pela materialidade assumida por essa discursividade" (DIAS, 2004, p. 19). Dessa maneira, podemos dizer que novas formas de inscrição do sujeito e dos sentidos na história podem ser constituídas a partir da retomada da memória, em um movimento pelo qual, segundo Mittmann (2008, p. 11), "as expressões e os modos de dizer antigos passam a adquirir sentidos particulares, através de acontecimentos discursivos, numa reinterpretação que se faz necessária." Temos, assim, um jogo entre a estrutura e o acontecimento (PÊCHEUX, 2002), que instala, na ordem da língua, o movimento da retomada de palavras já existentes, como se elas brotassem no sujeito, de sentidos que já circularam em outros contextos e do vir-a-ser de outros, que se entrelaçam aos primeiros rompendo com o estabilizado, em uma tensão que constitui o próprio discurso, o qual significa "sempre de muitas e variadas maneiras. Sempre as mesmas mas, ao mesmo tempo, sempre outras". (ORLANDI, 2003b, p. 36)

Observamos que, dependendo de sua relação com a memória e a ideologia, o sujeitonavegador pode ocupar determinadas posições no discurso, que não são únicas, mas também não podem ser qualquer uma, o que indicia os limites para o ler, surfar e enunciar no suporte eletrônico, dos quais já tratamos anteriormente. Apesar de não podermos desconsiderar as restrições que impedem o alcance do "todo", sugerimos que a Internet abre espaço para a circulação de sentidos mais plurais e o sujeito-navegador, na ânsia de desbravar outros mares, diante da amplidão do oceano digital, experimenta a Internet de muitas formas: representando suas fantasias e experimentando "alter-egos de maneiras que muitos de nós não nos arriscaríamos a fazer no mundo físico" (WERTHEIM, 2001, p.175), valendo-se, frequentemente, do apagamento dos nomes (substituídos pelos nicknames- apelido), imagens (agora, avatares) ou marcadores sociais do espaço físico, como o país; ocupando lugares que, muitas vezes, são impossíveis no mundo real, dos quais ele pode enunciar de diferentes formas, de acordo com o jogo entre formações imaginárias e o modo como é interpelado pela ideologia e acessa o interdiscurso; recortando e ressignificando certas regiões de sentido, que podem migrar para outras em um segundo; compondo seus ditos e interditos trançando-os às vozes e discursos de outros sujeitos dispersos na rede.

Inferimos também que, além da possibilidade de emergência da polissemia e da ocupação de outras posições-sujeito, a rede abre espaço para a inclusão e enunciação dos sujeitos aos quais foi negada a palavra, em outros contextos; instala-se, assim, um furo, uma rachadura no movimento de silenciamento, por meio da qual o sujeito resiste, "se rebela contra o que é ou está naturalizado, o que inquieta a ordem e desconstrói o silêncio. $\mathrm{Na}$ 
gangorra da memória e do silêncio, o sujeito resiste e insiste em materializar sua presença, instalam (-se) dizeres que dão corpo e link aos sentidos de sua exclusão" (ROMÃO, 2004a, p. 44). Assim, a mesma Web que contribui para a punição de sujeitos-internautas- ao serem reveladas suas identidades e dados do acesso a conteúdos proibidos, discursos contrários à formação discursiva dominante- faz com eles tenham a oportunidade de passear por diferentes formações discursivas, observar as várias vozes que as constituem, a porosidade destas formações, que se interpenetram, reverberando os sentidos que não querem/podem calar, conforme se pode observar nos exemplos apontados por Manguel (2006, p. 112):

No Irã tiranizado pelos mulás, os estudantes podem ler on-line todo tipo de literatura proibida; em Cuba, os dissidentes tem acesso, via Internet, aos relatórios publicados pela Anistia Internacional e por outras organizações em prol dos direitos humanos; na Rodésia, os leitores podem abrir na tela os livros de escritores proibidos.

Entretanto, vale ressaltarmos que para que os sujeitos sejam realmente incluídos no ciberespaço é preciso mais do que o acesso à Internet e outras ferramentas de comunicação e informação, sendo fundamental que eles se relacionem com os sentidos postos em circulação nas redes eletrônicas, que participem ativamente dos jogos de (re)construção e interpretação dos discursos que elas sustentam. Assim, ainda que a rede abrigue sentidos plurais, isto não é suficiente para uma democratização dos discursos, visto que "não basta as idéias estarem lá depositadas, é preciso que elas circulem, que elas tomem corpo, que elas reverberem, isto é, que elas entrem na ordem do discurso e não fiquem apenas 'à deriva na superfície das águas' (MELO, 2005, p.137).

É importante destacarmos ainda que a partir das novas possibilidades de enunciação oferecidas pelo ciberespaço aos sujeitos, estes podem construir seu discurso ocupando diversas posições, como a de autor, que, para a Análise do Discurso, não é aquele que escreve ou assina um texto. Segundo Orlandi (1988, p. 77), a função autor é aquela assumida pelo 'eu' enquanto produtor de linguagem, "a dimensão discursiva do sujeito que está mais determinada pela relação com a exterioridade (contexto sócio-histórico), ela está mais submetida às regras das instituições. Nela são mais visíveis os procedimentos disciplinares”. Portanto, é na função autor que a relação do sujeito com a língua está mais propensa ao controle social, sendo-lhe exigidos coerência, clareza, respeito a normas e padrões estabelecidos, relevância, unidade e criatividade, a fim de que ele se torne visível enquanto autor, o que significaria ser controlável, calculável e identificável. Por conseguinte, é do autor que mais se cobra a ilusão de ser a origem do dizer. 
Para que o sujeito se coloque como autor, é necessário que ele estabeleça uma relação simultânea com a exterioridade e a sua interioridade, na qual constrói sua identidade como autor e aprende a assumir este papel e suas consequências. Deste modo, segundo Orlandi (1988, p. 79), o autor é o sujeito "que, tendo o domínio de certos mecanismos discursivos, representa, pela linguagem, esse papel, na ordem social em que está inserido." Em outras palavras, para ser autor, o sujeito tem que assumir uma posição de responsabilidade pelo que $\operatorname{diz}$,

preenchendo espaços lacunares com estratégias de contenção dos sentidos e de amarração do seu dizer na ancoragem de outros dizeres e na rede da memória. Tal manobra não é fruto da vontade do indivíduo nem do querer das suas intenções, mas fruto da tensão existente entre a memória do dizer e a ideologia, que torna alguns sentidos naturais e evidentes para o sujeito em determinada posição, apagando ou sabotando completamente outras formas de dizer. Assim, o princípio da autoria tem sua materialidade linguística na injunção ideológica, que interpela o sujeito em um ponto da rede da memória e não em outro, fazendo-o buscar o efeito de unidade para o seu dizer, ainda que eles - dizer e efeito - sejam imaginários. Essa posição, em que o sujeito tenta controlar a deriva e os pontos de fuga dos sentidos e busca amarrar o fio do discurso, cria para o seu dizer um fecho imaginário com começo, meio e fim. (ROMÃO, 2006, p. 315)

Diante desta posição de responsabilidade pelo dizer e do ilusório propósito de unidade e contenção da deriva que são almejados pelo sujeito-autor, podemos questionar se e como o conceito de autoria sofre mudanças, no contexto de um ciberespaço descentralizado, fragmentado, não-linear, "que não inibe a heterogeneidade e não cria necessariamente uma cultura monolítica" (LEMOS, 2007, p.146), ou seja, indagar se é possível que o sujeito constitua-se neste espaço como autor. Sem apresentarmos certezas absolutas, consideramos a hipótese de que a função-autor é assumida de maneira diferente na rede eletrônica, onde é dada ao sujeito "a possibilidade de ele misturar-se a vozes heterogêneas dissolvidas e esgarçadas nos fios da rede, fundindo-se a elas para assentar-se no mesmo lugar ou desinstalando-as para confrontá-las" (ROMÃO, 2006, p. 308). A partir do outro, o sujeito enuncia, tentando, em cada nó, sobreviver à deriva que é constitutiva da linguagem, do sujeito e também da rede, para ser reconhecido como autor do seu dizer, historicizando os sentidos que produz; deste modo:

A título de ensaio, talvez se possa pensar a autoria instalada em cada mensagem, em cada frase, em cada inscrição de linguagem, tangenciando da preocupação de ler o todo, a sequência, o encadeamento e os mecanismos de reatroação do sujeito. Em cada link, a tentativa de materializar um fragmento de dizer e de autor; em cada nó da rede, um movimento isolado de escrever- 
se como posição que não contém a deriva, mas sobrevive a ela. (ROMÃO, 2006, p.326)

Assim sendo, na provisoriedade e fluidez das redes eletrônicas, restaria ao navegador: "o prazer de provar os pedaços sem a dimensão do todo, de experimentar as margens sem reconhecer o centro, de andar sobre fios imaginários sem o apoio das vias reais do papel e, enfim, de equilibrar-se nos desvãos dos nós e pontos de uma rede que não se vê a urdidura" (ROMÃO, 2005b, p. 10). A partir desse percurso teórico, investigaremos se e como o sujeitonavegador, na posição de bibliotecário, tece seus percursos de sentidos em sites e blogs da rede, marcando como são inscritos seus movimentos de dizer e de ser autor/navegador de sentidos mais polissêmicos na rede eletrônica. Para isso, faremos a partir de agora um passeio problematizando questões relacionadas à biblioteca no âmbito da escola e(m) seus históricos efeitos de apagamento e, depois, à emergência da biblioteca escolar digital e os modos de dizer dos sujeitos-navegadores. 


\section{BIBLIOTECA ESCOLAR: SENTIDOS EM MOVIMENTO}

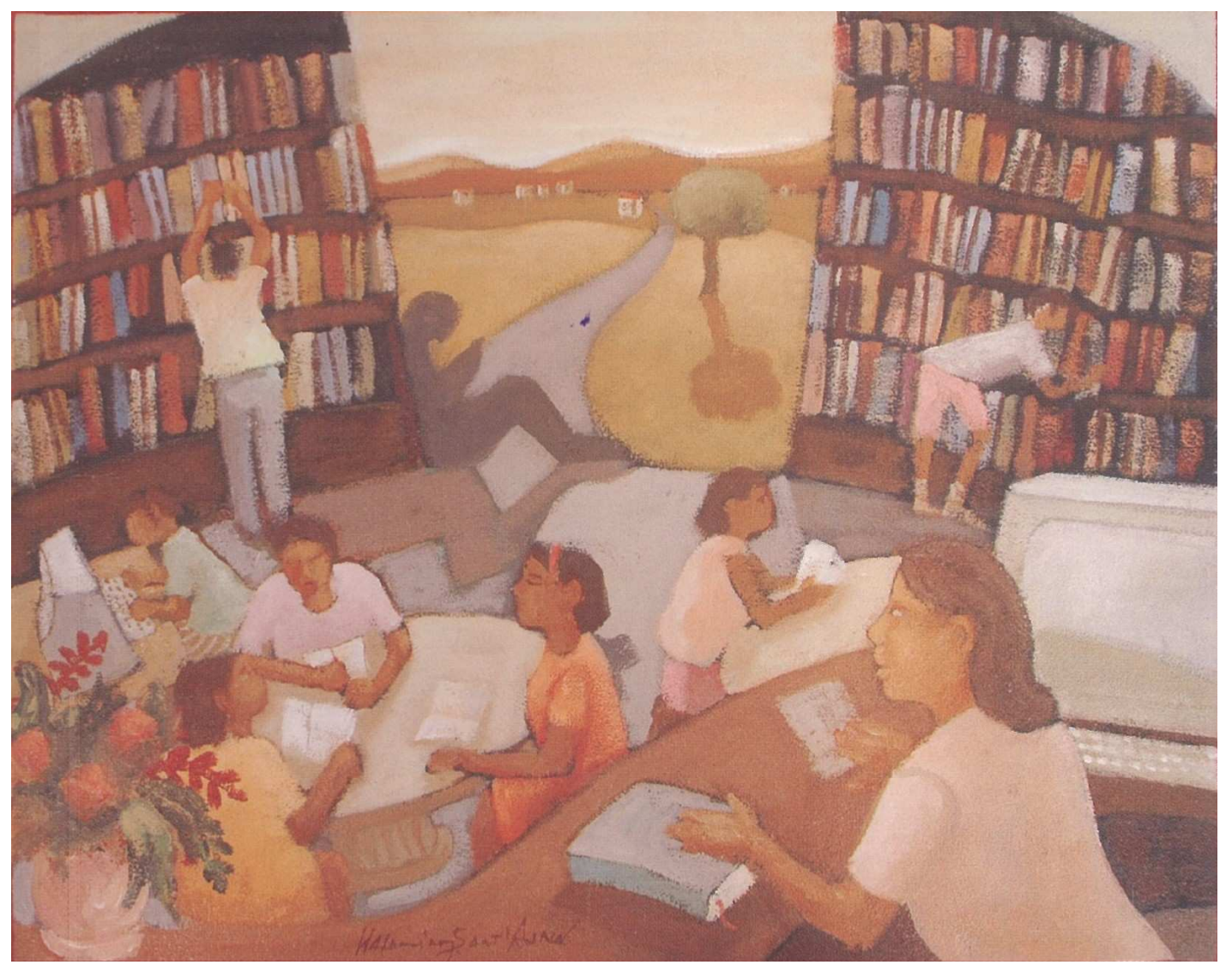

Figura 4. [Biblioteca escolar]

A biblioteca era o mundo colhido num espelho; tinha a sua espessura infinita, a sua variedade e a sua imprevisibilidade. (SARTRE, 1978, p. 32) 
Ocupando a posição de analistas do discurso, apresentaremos nosso objeto discursivo, a biblioteca escolar, a partir da multiplicidade que lhe é constitutiva, o que nos leva a destacar duas regiões de sentido que a significam e delineiam o que seriam duas formações discursivas: uma em que circulam os sentidos de valorização e outra marcada por uma concepção mais restrita, em que se destacam as inúmeras faltas e problemas que a afetam. Estas duas regiões de sentido não são homogêneas, estanques, mas porosas, pois se interpenetram nos jogos de linguagem. Assim sendo, consideramos que os sentidos não estão enrijecidos, mas deslocam-se a todo instante, sendo torcidos, enviesados, atravessados por outros e entretecidos de diferentes maneiras, nas tramas entre o discurso e a ideologia, a partir da retomada da memória e das condições de produção do dizer.

Deste modo, antes de analisarmos quais sentidos foram mobilizados na constituição dos discursos sobre biblioteca escolar que circulam nas redes da Internet, falaremos acerca dessas formações discursivas que sustentam e delineiam os sentidos sobre esta instituição: primeiramente, abordaremos os sentidos de restrição historicamente atribuídos às bibliotecas, apresentando sua trajetória no contexto brasileiro e as práticas cotidianas que os sustentam; em seguida, iremos discorrer acerca dos sentidos que conferem importância e destaque a esta instituição, regulando como ela deve ser concebida e atuar no âmbito escolar, o que frequentemente difere muito do que se observa nas escolas brasileiras. Por último, serão tecidas algumas considerações acerca da biblioteca escolar digital, sua constituição e contribuições para as práticas educativas.

\subsection{Memória e atualização de sentidos sobre biblioteca escolar: imbricações}

Fôssemos infinitos tudo mudaria/ como somos finitos, muito permanece. (BRECHT, 2000, p.343).

Faremos agora um percurso buscando mobilizar os sentidos acerca da constituição e desenvolvimento das bibliotecas escolares no Brasil, aqueles que permanecem e retornam, pela memória discursiva, evocando efeitos de restrição, denunciando a inércia e precariedade que marcaram, desde o início, no século XVI, as bibliotecas escolares brasileiras. A partir de tais sentidos, as bibliotecas foram discursivizadas como coleção de livros ou espaço físico, o que vai de encontro à concepção tida como ideal, da qual falaremos na próxima seção. Como instrumento de poder controlado pelo clero ou pelo Estado, a biblioteca manteve suas portas fechadas à maioria da população, instalando uma divisão entre “'letrados' e 'iletrados', entre ‘clérigos' e 'laicos', entre iniciados à palavra escrita e os não iniciados” (MAROTO, 2009, p. 
32); encerrada nos palácios, ou nos conventos, não era vista como órgão de acesso e difusão do conhecimento. Marcamos que tais relações de desigualdade de acesso às bibliotecas e aos livros são atualizadas pelos discursos que enunciam, além da falta, o distanciamento entre as bibliotecas escolares, as tecnologias de informação e computação e os sujeitos-leitores, apontando um furo na formação discursiva dominante que atesta a emergência de uma sociedade de informação, da qual todos poderiam participar. A história das bibliotecas no Brasil começou em 1549, com a vinda dos primeiros missionários jesuítas e dos livros trazidos por eles. Segundo Nascimento (2000, p. 2), “em 1583, no Colégio da Bahia, havia já uma boa biblioteca", chamada na época de livraria. Observamos a importância que era conferida a essa instituição e aos livros, visto que eles eram vistos como essenciais para a formação dos jesuítas; por conseguinte:

a sua falta prejudicava as atividades da ordem na catequese dos índios, assistência religiosa, ensino e educação dos colonos. E assim procuravam instalar livrarias em todos os seus estabelecimentos, desde os mais importantes, situados nas sedes da província até os mais modestos nas distantes aldeias. [...] As primeiras livrarias eram as dos colégios, que tiveram seu apogeu no século XVII e na primeira metade do XVIII. (SILVA, 2008, p. 221)

Com as dificuldades de acesso às obras, os religiosos assumiram a função de copistas, confeccionando o que seriam os primeiros materiais didáticos produzidos no país. Sendo assim, a situação dos acervos das primeiras bibliotecas escolares era precária, havendo escassez e restrição do uso:

Pela escassez de livros na Colônia e as dificuldades financeiras da Companhia de Jesus os acervos das bibliotecas dos colégios eram 'esmolados', isto é, doados à biblioteca quando da morte de algum padre. Esta dificuldade inviabilizava qualquer tipo de empréstimo aos escolares, pois acreditavam que 'para arruinar-se em pouco tempo uma biblioteca, basta emprestar os livros' (MORAES, 1979). Esse fato propiciou a ordenação, em 1589, de todos os livros existentes nas bibliotecas dos colégios' [...] Esse controle não se dava somente para evitar danos e furtos, mas, principalmente, para se saber quais livros deveriam ser lidos pelos alunos. (CASTRO, 2003, p. 65)

Instalaram-se, assim, práticas de controle que ainda hoje são encontradas em diversas bibliotecas escolares, de todo o país, que se mantém fechadas ou restringem a circulação de sujeitos e obras, consolidando ações que consideramos nocivas ao despertar do gosto de estar em uma biblioteca e entre os livros, delineando sentidos negativos para esta instituição. Conforme Silva (2008, p. 227), outra prática restritiva adotada era a censura das obras, pela qual "antes que fossem dispostos para consulta, os livros passavam por exame. Determinava- 
se que fossem corrigidos aqueles que contivessem conteúdo contrário à edificação e bons costumes", instalando-se, assim, a política do silêncio, pela qual "se obriga a dizer ' $\mathrm{x}$ ' para não deixar dizer 'y'." (ORLANDI, 1997, p.83), a fim de que seja interditada a inscrição do sujeito em certas formações discursivas não-autorizadas. Como nos conta Válio (1990), apesar das dificuldades, aos poucos os acervos foram se multiplicando, tornando-se de uso particular dos jesuítas, visto que não havia no país nenhum outro tipo de biblioteca ou livraria que promovesse a formação de leitores; além disso, as exorbitantes taxas de analfabetismo também colaboravam para delinear este círculo fechado de leitores privilegiados. Com a expulsão dos jesuítas, em 1579, as bibliotecas dos colégios foram praticamente abandonadas, coleções foram saqueadas ou destruídas pela falta de conservação, conforme nos conta Silva (2008, p. 232):

Com a saída dos jesuítas, todos seus bens imóveis e móveis foram confiscados e tiveram destinos diversos. No que tange às bibliotecas e seus livros, veio a ocorrer um completo desmantelamento e desaparecimento dos acervos construídos ao longo de 200 anos. A história desse período, uma parte da história da destruição das bibliotecas no mundo, é ainda desconhecida.

A censura (política do silêncio), já praticada, enrijeceu-se e o acesso aos livros e outras fontes impressas só foi regularizado a partir de 1810, com a vinda da Corte Portuguesa ao Brasil. (MAROTO, 2009). Após esse período, passou-se da censura religiosa à real, visando à interdição de quaisquer sentidos contrários à formação discursiva dominante, tidos como subversivos, perigosos. A partir da censura e outras práticas cerceadoras, a biblioteca escolar, no século XIX, atualizou práticas medievais que perduraram ao longo da história, evocando sentidos que a concebem como um lugar inacessível, sagrado e silencioso:

Tal como no período medieval, a prática da censura e os dispositivos do regulamento da biblioteca brasileira do século XIX a caracterizavam como o lugar 'augusto e sagrado', o espaço do silêncio, inacessível às camadas populares, simples e trabalhadoras. A elitização da leitura e do livro, as normas rígidas e proibitivas e a ausência da tradição bibliotecária vem permeando a humanidade por séculos a fio e, ainda hoje, em pleno século XXI, tem reflexos na maioria das escolas brasileiras onde a biblioteca escolar, quando existe, é o lugar do silêncio, o espaço do castigo. (MAROTO, 2009, p. 18).

Durante a Primeira República (1889-1930), as bibliotecas continuaram sofrendo com falta de recursos e a postura limitada pela qual são concebidas como estoques de materiais, depósitos de livros. As bibliotecas inauguradas no período, segundo Castro (2003), não foram frutos de iniciativas governamentais, mas de ações isoladas de professores. Como 
apresentaremos em breve, o descaso do governo e a falta de práticas estruturadas são uma das causas da precariedade em que se encontram, hoje, muitas bibliotecas escolares brasileiras. Voltando à nossa discussão, observamos que, após esse longo período de estagnação, na década de 1930, com as novas e mais amplas concepções educacionais que estavam em voga, surgiram discussões que valorizaram a biblioteca, atribuindo-lhe um papel essencial para a educação. A partir delas:

iniciativas de promoção da leitura e de valorização da biblioteca começaram a surgir no país com a criação de bibliotecas infantis em alguns estados, além da instituição de programas e projetos de leitura, nas últimas décadas do século $\mathrm{XX}$, desenvolvidos junto às escolas da rede oficial de ensino, e a outras instituições públicas e privadas comprometidas com a formação do leitor. (MAROTO, 2009, p. 19)

Entretanto, segundo Castro (2003), essa breve movimentação em torno da biblioteca escolar foi encerrada no Estado Novo, que marcou o início da ditadura varguista (de 1937 a 1945) e novas ações em prol da censura, proibindo os livros que continham "ideologias subversivas" e promovendo aqueles que abordavam valores morais e patrióticos "adequados", que deveriam ser inculcados na população, através de sua distribuição. Assim sendo, destacou-se, neste período, a criação de uma política assistencialista, por meio da qual se distribuíam livros às escolas e bibliotecas públicas, como forma de dominação disfarçada em ações caridosas de um "bom governo" que "cuida" da população, levando a cultura até ela. Estes programas governamentais assemelhavam-se aos que estão em vigor e, da mesma maneira que eles, não contribuíram para a instituição e desenvolvimento de bibliotecas escolares, visto que, para nós, estas não correspondem a apenas uma coleção de livros.

Em seguida, houve uma nova tentativa de desenvolvimento das bibliotecas, que foi interrompida pela instauração de outra ditadura, mais rigorosa e repressora: a ditadura militar, que vigorou de 1964 a 1985 e se voltou para "a acomodação e para a alienação sócioinformacional, igualando-se ao período ditatorial de Vargas" (CASTRO, 2003, p.69). Também foi organizada uma política de distribuição de livros, por meio do Programa Nacional do Livro Didático, que visava adquirir livros das editoras e distribui-los para as bibliotecas escolares e universitárias. Entretanto, mais do que dotar as bibliotecas de recursos bibliográficos necessários à educação, estes programas assistencialistas contribuíram para o enriquecimento de editoras, sendo por esta razão extintos pelo governo federal, em 1971, após a solicitação de observadores internacionais; foi nesta época que, segundo Castro (2003, p.6970), a censura agravou-se: 
Censura que rastreia o que deveria ser lido, estudado ou pesquisado, da educação infantil à educação superior. O Decreto 1077, de 6 de janeiro de 1971, do Ministro Alfredo Buzaid, determinava que a divulgação, leitura e acesso a livros e periódicos (nacionais e estrangeiros), em todos os níveis de ensino e em todas as bibliotecas, ficariam subordinados à verificação prévia da Polícia Federal a quem caberia analisar a existência de material ofensivo à moral e bons costumes.

A partir dos anos 1980, com o fim da ditadura militar e a abertura política, não houve um expressivo período de desenvolvimento das bibliotecas escolares:

o diálogo entre ensino e biblioteca não reacendeu da mesma maneira quando do término dos períodos ditatoriais anteriores. Projetos desconexos e sem continuidade têm sido engendrados pelo Estado, o que nos autoriza a afirmar que, no âmbito governamental, não há qualquer ação efetiva para o fortalecimento do diálogo entre ensino e biblioteca. Através de um discurso pseudo-moderno vivencia-se, atualmente, uma deturpação do conceito de ensino, de escola e de biblioteca, agora traduzido sob o binômio máquinainformação. (CASTRO, 2003, p. 70)

A situação descrita, acima, representa um quadro de dificuldades ainda recorrente no país, que nos chama a atenção, visto que, como analistas de discurso, consideramos que todo dizer é datado sócio-historicamente, sendo determinado por relações materiais de força, de disputas e de tensões advindas das formações sociais. Assim sendo, marcamos que o descaso, censura, ações equivocadas e práticas intermitentes que rondaram a biblioteca escolar, desde seu início em solo brasileiro, deixaram cicatrizes que podem ser observadas no cotidiano das escolas e nas falas dos sujeitos escolares. Por meio delas, são evocados os sentidos que sustentam a concepção de biblioteca como um espaço físico, um simples 'aposento", ou como uma coleção de livros, retomando sentidos circulantes no período seiscentista:

A primeira acepção é a mais clássica: 'Biblioteca: aposento ou lugar onde se colocam livros; galeria, construção cheia de livros. Diz-se também de livros que são geralmente arrumados sob construções compridas e em arcos'. Segue-se um segundo sentido que designa não mais um espaço, mas um livro: 'Biblioteca é também uma coleção, uma compilação de várias obras da mesma natureza, ou de autores que compilaram tudo que se pode dizer de um mesmo tema' (DICTIONNAIRE DE FURETIÈRE, 1690 apud CHARTIER, 1999, p.70).

Essa forma reducionista de conceber a biblioteca, ao ser dicionarizada, afirma-se como um saber já-dado, digno de confiabilidade, que é legitimado como verdadeiro, apagando outros que poderiam estar em seu lugar. É interessante observarmos como, atualmente, apesar da emergência de discursos mais plurais sobre a biblioteca, esses sentidos restritivos insistem em retornar pela memória discursiva, sendo concebidos como algo que se deve saber, como podemos notar na definição de "biblioteca" que é dada pelo dicionário Michaelis: "Coleção de 
livros, dispostos ordenadamente", "Edifício público ou particular onde se instalam grandes coleções de livros destinados à leitura de frequentadores ou sócios", ou ainda, "Estantes ocupadas por livros" (TREVISAN, 1998). Ainda que esta última definição, contemporânea, mencione a leitura, sabemos que a biblioteca não pode ser concebida apenas a partir de seus aspectos físicos e materiais, sendo mais do que livros e um espaço pra leitura, visto que abrange uma série de outros materiais e atividades que a distanciam dessa visão restrita, que vem sendo atualizada, desde o século XVI, para significar as bibliotecas escolares brasileiras.

Estes sentidos seculares insistem em retornar nos discursos contemporâneos, sustentados pelas condições sócio-históricas, que envolvem a falta de bibliotecas, recursos materiais, bibliográficos e de profissionais habilitados. Outra prática que colabora para a emergência desses sentidos parafrásticos, em relação à biblioteca e às atividades nela realizadas, diz respeito às já citadas políticas de distribuição de livros, das quais falaremos agora. Consideramos que as iniciativas de promoção da leitura giraram em torno da distribuição de livros, iniciada na década de 1930 e tratada mais especificamente pelas políticas públicas, a partir dos anos 1980, embora isto não tenha significado sua generalização, já que nem todas as escolas eram atendidas e não havia uma periodicidade. (PAIVA, 2009). Para nós, tais políticas são restritas, pois não contemplam nenhum outro aspecto além da doação, não importando se e como tais livros serão recebidos e utilizados:

destinam recursos para a compra e distribuição de livros de literatura nas
escolas, mas duas outras situações não são contempladas: nenhuma atenção é
dada para os poucos educadores de bibliotecas, nem para os espaços físicos
da biblioteca, e a mais intensa ou menos intensa presença da literatura fica à
mercê das decisões isoladas de docentes (ARENA, 2009, p. 180).

Assim, as políticas públicas insistem em reunir, mas não em dispersar as obras doadas, deixam tal encargo às escolas, aos professores, já que praticamente inexiste o cargo de bibliotecário na rede pública de ensino. Deste modo, segundo Paiva (2009, p.150):

quando não se investiga a visibilidade, o grau de conhecimento, a capilaridade dessas políticas no chão da escola, desconsiderando em que medida e de que maneira esses materiais são recebidos e usados pelos profissionais da escola, esvazia-se uma ação que poderia repercutir enormemente, no processo de formação de leitores.

Configurando-se desta maneira pouco profícua, tais ações podem ser vistas como distributivistas, "ou seja, trata os bens culturais como se fossem merenda, giz, lápis, borracha, sem considerar a dimensão simbólica dos bens culturais (os livros) que distribui e sua natureza especifica." (PERROTTI; VERDINI, 2008, p.15). Apesar de indispensáveis, 
acreditamos que a simples distribuição de livros não contribui para a formação de leitores, pois "somente com livros silenciosos e sonolentos no escuro silencioso dos espaços eventualmente abertos, a leitura não nasce, porque quem a faz nascer e existir são seus leitores com a mediação dos educadores de biblioteca. A leitura do livro de literatura não preexiste ao leitor: é criada por ele" (ARENA, 2009, p. 164).

Como o foco totalmente voltado para as atividades de distribuição de livros, menosprezam-se as questões relacionadas às condições necessárias para que o acervo seja posto em movimento e não fique abandonado em bibliotecas que funcionam como depósitos de livros e outros materiais não utilizados. Assim sendo, "o grande desafio a ser vencido é combinar a política de distribuição de livros com outras ações, tais como, dinamização dos espaços de leitura, implantação de centros de leitura multimídia, formação de professores como mediadores de leitura" (BEAUCHAMP; SILVA, 2007, p.4).

A respeito dos acervos das bibliotecas escolares, destacamos sua constante precariedade, ao serem formados, quase que totalmente, pelas obras impressas doadas pelos governos, as quais, muitas vezes, não são suficientes e nem interessantes para os sujeitosleitores, o que as leva a permanecerem fechadas nas estantes, não sendo abertas uma única vez. Sendo assim, observamos, assim como Almeida Júnior (2006), a falta de uma política de desenvolvimento de coleções, por meio da qual se abandona "a acumulação pura e simples do material em benefício da possibilidade de acesso ao mesmo, tornando a coleção consistente com as metas e objetivos da instituição a que serve" (VERGUEIRO, 1993, p. 15); sendo importante também que esse acervo vá ao encontro dos anseios dos sujeitos-leitores, que poderão então soprar a poeira, pôr a biblioteca em movimento.

Consideramos, também, que o simples recebimento de um acervo não significa a valorização da biblioteca, visto que ele não é suficiente e nem concernente às particularidades e necessidades de cada escola, sendo necessário, primeiramente, que a biblioteca exista, com uma estrutura adequada e profissionais preparados para mediarem as obras, instituírem projetos e atividades que aproximem a biblioteca de seus sujeitos-leitores e que façam dessa instituição um:

espaço discursivo em que todos estes sujeitos possam construir sentidos sobre a linguagem e o mundo, em que as páginas dos impressos e as telas eletrônicas possam ser permanentemente ressignificadas por outros sentidos em movimentos espiralados de manutenções ou deslocamentos [...] um espaço de circulação de diferentes sujeitos e discursos que se cruzam e atravessam no processo de produção de sentidos na escola. (FERRAREZI, 2007, p. 35). 
Deste modo, frisamos que a distribuição do acervo não equivaleria à "universalização do acesso" e do conhecimento, pois é necessário levar em conta se e como as obras distribuídas são lidas e interpretadas, e não a sua simples existência. Conforme nos conta PAIVA (2009, p. 150), essas questões ligadas à recepção e uso dos livros de literatura distribuídos por esses programas governamentais não são consideradas nas pesquisas, assim como:

são escassas as ações governamentais que visam ultrapassar a distribuição pura e simplesmente desses materiais. Ocorrem com menor frequência, ainda, as ações que viabilizam a formação de professores e profissionais que atuam nas bibliotecas escolares para o reconhecimento do potencial do material disponibilizado e suas possibilidades educativas no cotidiano escolar, em especial, na sala de aula e na biblioteca.

Realizadas de forma simplista, as ações de distribuição de livros não se convertem em um processo de formação de leitores críticos. É preciso "exercitar a análise crítica de cada obra selecionada, quando essa for posta em circulação, em uso e recepção nos espaços escolares" (PAIVA, 2009, p. 153), o que, para nós, implica considerar as condições sóciohistórico-ideológicas de produção do discurso, o interdiscurso e as relações desiguais do poder, de poder dizer e saber. Segundo a autora, apesar das críticas ao PNBE (Programa Nacional Biblioteca da Escola), "os acervos estão chegando nas escolas e a melhor maneira de refletir sobre o seu potencial, e a sua adequação, é colocá-los em uso, da maneira mais consistente e problematizadora possível.” (PAIVA, 2009, p. 153). Assim sendo, reconhecemos que tais programas de distribuição de obras são importantes, mas que devem ser vistos como inicio e não o fim das ações em prol da leitura e valorização das bibliotecas. Marcamos que essas ações políticas, ao considerarem que a distribuição de livros é a solução, minimizam e simplificam as questões e os problemas relacionados à leitura e à pesquisa, agravando-os, pois são apagadas as discussões e reflexões que poderiam culminar em práticas mais frutíferas.

Consideramos que as diversas práticas restritivas realizadas nas bibliotecas escolares brasileiras atualizam os sentidos de biblioteca imaginarizada ora como um lugar "sagrado", restrito a poucos, ora como uma instituição burocratizada, que serviria apenas para "consulta e pesquisa, assim como para armazenar bolor, cupins e traças. Para poucos, aqueles que a frequentam assiduamente, ela constitui o local do encontro com o prazer de ler, conhecer, informar-se.” (FRAGOSO, 2002, p. 124). Nessa conjuntura, o silêncio atravessa a biblioteca de forma tão contumaz quanto os "imperativos da ordem e do espaço." dos quais nos fala Manguel (2006, p. 99). Tais imperativos reforçam a falsa relação de sinonímia biblioteca $=$ 
acervo, pois, conforme nos diz Silva, W. (2003, p.15): “às vezes, a biblioteca é um armário trancado, situado numa sala de aula, ao qual os alunos só têm acesso se algum professor se dispõe a abri-lo... quando a chave é localizada". Vistas a partir desta ótica restrita e utilitária, as bibliotecas serviriam apenas como um "local alternativo" à sala de aula, secundário, pouco frequentado, palco de atividades isoladas e alheias ao projeto pedagógico, perdendo-se, assim, excelentes oportunidades de enriquecimento do processo de ensino-aprendizagem. Essa situação encontrada em várias escolas do país é ainda mais grave naquelas em que a biblioteca não existe. Assim, temos, conforme nos diz Milanesi (2002), um sistema que garante o acesso à educação formal, mas, na prática, o acesso à informação é negado. Observamos que é a partir da falta de acesso às escolas e às bibliotecas escolares, que se dá a primeira forma de exclusão dos sujeitos à esfera informacional, que entendemos ferir um direito do cidadão e do sujeito-leitor.

Se a distribuição de riquezas materiais é injusta, mais ainda é a impossibilidade de acesso à informação - esta que seria o instrumento mais poderoso para superar condições que tornam os homens desiguais. Excluir a informação das necessidades básicas - vista às vezes como inútil ou perigosa é cortar pela raiz um direito sem o qual os indivíduos perdem outros. (MILANESI, 2002, p. 104-105)

Assim sendo, ao considerarmos o percentual de alunos de creche e educação infantil atendidos, observamos como ainda é muito pequena a oferta de bibliotecas (respectivamente 24,9\% e 33\%). (BRASIL, 2009). A partir desses números, marcamos que a inexpressiva disponibilidade de bibliotecas para aqueles que estão iniciando a sua vida escolar afeta muito o desenvolvimento do gosto pela leitura, especialmente para aqueles que não contam com livros e/ou não são estimulados no âmbito familiar, restando-lhes apenas as atividades realizadas na sala de aula, nem sempre suficientes e instigantes. Assim sendo, será apenas no ensino fundamental e médio que um maior número de alunos poderá contar com uma biblioteca, ou seja, quando ele já foi afetado pelas práticas de leitura e pesquisa restritivas e monótonas, frequentemente praticadas nas salas de aula e sustentadas pelo foco no livro didático, o que afetará a construção de discursos sobre a biblioteca escolar (agravado pelas condições precárias, não raramente encontradas) e o seu uso. Entretanto, apesar dos índices relativos ao ensino fundamental serem um pouco maiores, "há necessidade de rápida ampliação no atendimento aos alunos no caso de recursos tais como biblioteca (57\%)" (BRASIL, 2009, p.12). Destacamos, ainda, que as cifras mais otimistas referem-se ao ensino médio, onde $74,2 \%$ dos alunos tem acesso a bibliotecas. 
Já a pesquisa realizada, em 2007, pelo Instituto Pró-livro (2008, p. 15), apontou que a existência de biblioteca não significa que ela seja adequada, nem frequentada, pois "muitos dos entrevistados sequer conhecem esse equipamento no bairro ou na cidade. [...] A essa desinformação, soma-se a incômoda indicação de que apenas $10 \%$ dos entrevistados frequentam assiduamente tal espaço", sendo que "3 em cada 4 brasileiros não vão a bibliotecas" (INSTITUTO PRÓ-LIVRO, 2008, p. 94). Entre as causas para esse escasso uso de bibliotecas, $20 \%$ dos leitores alegaram que não as frequentam devido aos problemas que elas apresentam. Sendo assim, inferimos que o baixo uso de bibliotecas envolve uma série de questões, como a própria inexistência e o seu desconhecimento, a precariedade já citada, a falta de interesse, de estímulo e dificuldade de acesso à leitura e às bibliotecas, além de problemas ainda mais graves, dos quais já falamos, como o analfabetismo e a baixa escolaridade, visto que "21 milhões dos que não lêem são analfabetos e 27 milhões só cursaram até a $4^{\mathrm{a}}$ série do Ensino Fundamental." (INSTITUTO PRÓ-LIVRO, 2008, p. p. 103). Entre os leitores de livros, a biblioteca não é o local privilegiado, pois apenas $12 \%$ realizam nela a leitura. Também foi apurado que a maioria dos leitores é constituída por estudantes, mais da metade são crianças e adolescentes, o que demonstra a importância de que exista uma biblioteca escolar que atenda os alunos, professores e a comunidade, oferecendo o acesso a diversas obras e atividades dinâmicas, criativas e interessantes de leitura, escrita, pesquisa e outras, que instiguem e estimulem o prazer de ler e frequentar outras bibliotecas, ao longo da vida, como as públicas, universitárias e comunitárias.

A escuta desses dados acerca da leitura, leitores e bibliotecas, no Brasil, leva-nos a reiterar nossas considerações de que, além de um investimento em projetos educativos, bibliotecas escolares e sua estrutura, acervo e atuação na comunidade escolar, é imprescindível que se abra, na escola e biblioteca, espaço para emergência de um sujeito que ocupe a função-leitor (PACÍFICO, 2002), que teça outra relação com a leitura, qual seja, como construção de sentidos, pois, acreditamos que o ato de ler "não se esgota na decodificação pura da palavra escrita ou da linguagem escrita" (FREIRE, 1989, p. 12). Portanto, as questões de acesso/inclusão vão muito mais além da existência de bibliotecas, de espaços físicos, sendo necessárias ações que as incluam e signifiquem no contexto escolar, passando de uma postura inerte para a de agente num processo de ensino/aprendizagem mais criativo, que compreenda que o "o sujeito escolar é antes de tudo um sujeito de linguagem. E como tal precisa atribuir sentidos" (CASTELLANOS PFEIFFER, 2002, p.11). Assim sendo, como apontamos em trabalhos anteriores, "ter acesso à biblioteca não significa, necessariamente, estar incluído, do mesmo modo que doar ou distribuir livros não implica a 
formação de bibliotecas e ou a emergência de sujeitos-leitores" (FERRAREZI; ROMÃO, 2008a, p. 129).

Além disso, é importante considerarmos o que se está chamando de biblioteca: locais apropriados, agradáveis, vivos, habitados por livros e outros materiais, que são postos em circulação por profissionais e alunos, ou uma sala fechada? Tais sentidos não são discursivizados nas pesquisas realizadas, sendo difícil traçar um paralelo acerca das condições das bibliotecas escolares, ao considerar-se que a existência de um espaço e uma coleção, quase sempre restrita aos livros doados por programas governamentais, seria o suficiente para haver uma biblioteca figurando (ou não) nas pesquisas. Não podemos (nem queremos) fazer uma leitura literal e ingênua, nem considerarmos que é possível a objetividade da linguagem, que é reforçada pelas estatísticas, tão utilizadas no discurso político, científico e midiático, pois:

Ao apresentar o número como prova contundente, o sujeito desse discurso produz o sentido de certificação, de conhecimento da realidade [...] o uso do número põe em funcionamento o sentido de exatidão e de mapeamento seguro e comprovado dos fatos, do qual o leitor não ousaria discordar, visto que, como já dissemos, há no número o efeito ideológico de um dado irrefutável. (FERRAREZI; ROMÃO, 2006)

Deste modo, é importante entendermos os problemas de forma mais ampla, crítica, duvidando da transparência da linguagem e buscando considerar a ideologia e as relações de poder que influem na constituição dos discursos sobre a biblioteca e os leitores. Tal postura nos leva a superar uma visão simplista, por meio da qual se pode pensar, por exemplo, que a Lei $n^{\circ} 12244$ de 24/05/2010 (que “dispõe sobre a universalização das bibliotecas nas instituições de ensino do País") seria a solução derradeira para os problemas enfrentados pelas bibliotecas escolares brasileiras. (ANEXO 4)

Antes de falarmos um pouco a respeito desta lei, é importante destacarmos que os dizeres oficiais sobre a biblioteca escolar ocupam uma suposta posição de autoridade, prestígio e veracidade, a partir da qual são recortadas algumas regiões do interdiscurso, naturalizadas como os únicos sentidos passíveis de circulação e legitimação, enquanto outras são silenciadas; a partir desse lugar de aparente onipotência e completude, a lei é tida como transparente, apagando a ideologia e as relações de força que afetam a produção dos discursos considerados, nesta perspectiva, como sendo evidentes, óbvios. A partir do exposto, observamos, nessa lei a pretensão de universalizar a biblioteca escolar, ou seja, disponibilizála a todos igualmente, imbuindo-se, para tanto, de poder suficiente para garantir, apenas pela escrita da lei, a concretização do que foi proposto, conforme podemos observar nestes recortes 
(BRASIL, 2010, p.3, grifos nossos): "as instituições de ensino públicas e privadas de todos os sistemas de ensino do País, contarão com bibliotecas, nos termos desta Lei", "será obrigatório", “universalização das bibliotecas escolares, nos termos previstos nesta Lei”.

Inferimos que a referida lei não diz respeito à criação de verdadeiras bibliotecas, pois faz retornar, pela memória discursiva, sentidos historicamente parafraseados que as concebem como sinônimo de acervo, conforme podemos observar no seguinte recorte "Para os fins desta lei, considera-se biblioteca escolar a coleção de livros, materiais videográficos e documentos registrados em qualquer suporte destinados a estudo, consulta, pesquisa, estudo ou leitura" (BRASIL, 2010, p.3, grifos nossos). Além disso, frisamos que as medidas impostas pela lei referem-se apenas à existência desses materiais (em quantidade limitada) e a sua ordenação e conservação, conforme observamos no excerto: "Será obrigatório um acervo de livros na biblioteca de, no mínimo, um título para cada aluno matriculado, cabendo ao respectivo sistema de ensino determinar a ampliação deste acervo conforme sua realidade, bem como divulgar orientações de guarda, preservação, organização e funcionamento das bibliotecas escolares". (BRASIL, 2010, p.3, grifos nossos). Portanto, não são apontados quaisquer outros aspectos que julgamos relevantes, tais como as atividades de caráter literário, lúdico e pedagógico, a inclusão da biblioteca no projeto pedagógico da escola, planejamento orçamentário para colocar em movimento uma biblioteca mais dinâmica, com diversos materiais e recursos, etc., exigindo-se apenas a quantidade de obras a serem providenciadas.

Não podemos ignorar a importância de ter sido aprovada uma lei referente à biblioteca escolar, visto que o apagamento da mesma no discurso político impossibilita ações estruturadas, planejadas a longo prazo; entretanto, a biblioteca ainda é vista, pelo autoritário discurso jurídico, de forma limitada, fazendo retornar, pela memória discursiva, sentidos circulantes desde o início da história das bibliotecas, que a enunciam como um lugar imóvel, um simples depósito. Deste modo, concordamos com Perrotti (2008, p. 2) e sua afirmação de que:

Para superar condições de mero entreposto e tornar-se espaço de cultura vivo, dinâmico, atrativo, a biblioteca não pode simplesmente existir, entregando ao acaso sua dinamização. É preciso atuar, agir, criar metodologias e estratégias compatíveis com projetos históricos empenhados em reverter o quadro de exclusão que sempre marcou a vida nacional; é preciso combinar opções de políticas públicas inclusivas com práticas culturais da mesma natureza, criando-se uma dinâmica entre macro e micro ações visando à participação e inclusão de todos nos processos de conhecimento e cultura 
Inferimos que uma adequada estrutura contribui para que outras práticas sejam implementadas, visto que o estabelecimento de uma biblioteca em salas de aula adaptadas dificultam, segundo Furtado (2004) e Antunes (1998), o seu pleno funcionamento e continuidade, pois, a qualquer momento, por falta de espaço, estas salas podem ser desativadas, o que nos leva a dizer que a biblioteca escolar ainda se encontra em um longo estado de provisoriedade que, sustentado pela inércia do poder público, dificulta a superação dos problemas que a afetam. Segundo Silva e Bortolin (2006, p. 14), trata-se de "uma verdadeira improvisação que pode refletir no entendimento e no desejo de permanecer nesse ambiente", que se localiza, muitas vezes, no pior espaço, mal iluminado, contando com um mobiliário formado por tudo o que sobrou de outras repartições.

Há casos em que a biblioteca divide seu espaço com materiais de limpeza e entulho, não permanecendo aberta para seus leitores, por falta das mínimas condições que permitissem seu funcionamento, a mediação de livros, que permanecem guardados, empoeirados nas estantes, conforme nos conta Arena (2009, p.163):

livros guardados em cubículos mal iluminados, a conviver com baldes e panos de chão, ou guardados, e muito bem, a portas fechadas, por falta de quem os pudesse guardar junto aos livros de registro, com olhos atentos.

Neste contexto, muitas bibliotecas são confundidas com depósitos de livros, ou "armariotecas", desconhecidos pelos sujeitos que circulam na escola.

muitas bibliotecas se confundiam com depósitos de livros amontoados sem nenhum critério nem organização e, muitas vezes, encontraram-se os livros empacotados em suas embalagens originais. Outras se reduziam a "armariotecas", os livros encontravam-se guardados em armários trancados a chave, indisponíveis para consulta de alunos ou de professores. Em muitas bibliotecas não existiam registros dos livros em catálogos, o que implicava desconhecimento por parte da comunidade escolar sobre a quantidade e a qualidade das obras de que dispunham. (PAIVA; BERENBLUM, 2009, p. 13-14)

É interessante observamos que este descaso, presente ainda em muitas escolas, é promovido primeiramente pelo Estado, mas, depois, a instituição escolar acaba reproduzindo a estrutura estatal de desprestígio à leitura e à biblioteca (SILVA; BORTOLIN, 2006), reforçando os sentidos restritos já-ditos e repetidos sobre ambas. Este desprezo dos governos pela biblioteca pode ser percebido no longo período de "inexistência de um programa definido de implantação e implementação de bibliotecas escolares. Assim, o funcionamento das bibliotecas nas escolas fica dependente das ações da própria escola" (FURTADO, 2004, p. 3), 
as quais se configuram como precárias, visto que são fragmentadas. Sendo assim, a falta de planejamento é um dos grandes entraves ao desenvolvimento das bibliotecas, pois:

mesmo uma super biblioteca escolar, se não tiver um projeto de desenvolvimento, acaba cristalizando-se e morrendo de inanição. Apesar das dificuldades, sempre é possível articular recursos, criar conexões, lançar mão e otimizar as possibilidades por mínimas que estas sejam; por outro lado, sempre é possível aumentar as chances de um trabalho significativo ao se buscar cooperação, trocas, comunicação; sempre é possível, enfim, inventar, criar, ampliar, ao se estabelecer elos. (PERROTTI; VERDINI, 2008, p.21)

Tal assertiva nos leva a considerar que, diante de um contexto marcado por grandes dificuldades, é importante que a biblioteca escolar conte com um profissional que permita a emergência de práticas mais polissêmicas que a ressignifiquem, já que "não basta que a biblioteca exista fisicamente para que sua identidade se consolide. São os atores (coincidentes com o processo educativo) que lhe darão sustentação.” (ANTUNES, 1998, p. 177). Marcamos aqui que a necessidade de um sujeito-profissional preparado e também motivado para atuar nas bibliotecas não é comumente satisfeita na grande maioria das escolas públicas do país, nas quais o bibliotecário não é reconhecido, não faz parte do quadro de funcionários públicos. Entretanto, Fragoso (2002, p. 126) nos alerta para o fato de que nas instituições privadas também é constatada a ausência do bibliotecário:

Mesmo aquelas que podem se dar o luxo de algum aparato tecnológico e de
práticas mais modernas relutam em investir nos recursos humanos, deixando
que alguns velhos cacoetes culturais perdurem. Por exemplo, o de
improvisar um guardião que terá como missão, de fato, guardar o geralmente
precário material bibliográfico. E o fará, geralmente também, com um zelo e
uma rabugice de burocrata. Os leitores da assim chamada biblioteca -
crianças e adolescentes, em sua maioria - irão frequentá-la com igual
despreparo e desinteresse, sub-utilizando sempre os possíveis recursos. E o
contato prazeroso com a leitura - já de si tão problemático nestes tempos de
cultura visual -, este sim, passa por metamorfose definitiva: ler se torna mais
um entre os deveres escolares.

É muito frequente que no lugar dos bibliotecários sejam empregados professores denominados "readaptados", que são aqueles com problemas de saúde, afastados da sala de aula, pra onde retornam após o tratamento. Há também o caso de professores que ficam nas bibliotecas enquanto aguardam a aposentadoria ou outra oportunidade de trabalho e outros ainda são leigos (ANTUNES, 1998; SILVA, W. 2003). Assim como Furtado (2004, p. 4), consideramos que estes "não são os profissionais indicados para atuarem nas bibliotecas escolares, como é prática da realidade brasileira". 
O próprio termo "readaptado" inscreve sentidos de desajuste perante um determinado contexto ou situação vista como estranha, inadequada, mas na qual será preciso encaixar-se "acomodar-se", não sem dificuldades. Pela força da repetição, este termo nos parece estar naturalizado, ser óbvio dizer "professor readaptado", "professor de biblioteca", ou ainda, "professor-bibliotecário", em vez de "bibliotecário", como se todos estes termos fossem sinônimos, apagando a reflexão acerca dos mesmos, silenciando o sujeito-bibliotecário (cuja falta comumente não suscita mais estranhamento) e a própria indolência do governo em relação à biblioteca escolar que, por esse ângulo, poderia receber qualquer funcionário, não sendo importantes sua qualificação, disposição ou até mesmo condições de saúde adequadas para poder exercer as atividades, assim como o treinamento, planejamento das ações a serem implementadas ou ainda um plano de carreira. Sendo assim, a biblioteca seria vista mais como um depósito para funcionários, materiais e alunos indesejáveis em outros espaços, teria seu conceito deturpado, como nos conta Baró, Maña e Vellosillo (2001, p. 11): "es muy habitual en los centros colocar en la biblioteca a la persona que por algún motivo no puede ocuparse de un grupo de alumnos. Eso demuestra el concepto erróneo que se tiene de ella, a la que ven como un sitio de retiro, sin niños y con un trabajo tranquilo"

Diante desse quadro, consideramos importante que os profissionais bibliotecários, assim como educadores e outros setores da população, mobilizem-se em prol de que o poder público reconheça a necessidade de investir em uma escola de qualidade, o que implica a existência e ativação de bibliotecas (e não depósitos de livros distribuídos pelos governos), guiada por uma equipe multidisciplinar e preparada de profissionais que, a partir de seu empenho e apoio político-institucional, poderiam empreender ações que desafiem e superem as dificuldades que perpassam a educação no Brasil, unindo esforços para que as bibliotecas não fiquem estagnadas e fechadas por falta de alguém que nelas atuem, para que haja um profissional consciente do importante papel que a biblioteca é chamada a desempenhar e com condições e disposição para realizar um trabalho que vai muito além da guarda, organização e empréstimo do acervo, de forma contínua, planejada e em consonância com a realidade escolar. Por fim, destacamos que as várias ações isoladas, muitas delas voluntárias, empreendidas por professores e bibliotecários desejosos de contribuírem para uma nova configuração de biblioteca, são importantíssimas, contudo, como já dissemos, com o tempo podem ser interrompidas, por falta de apoio político e da própria comunidade escolar, conforme nos fala Bajour (2007, p. 2): 
As bibliotecas que funcionam como uma estrela são as que brilham com luz própria a partir de alguns projetos, por exemplo, relacionados com a promoção da leitura, mas que não têm caráter de vinculação com a instituição e seus rumos pedagógicos. Trata-se de iniciativas com grande visibilidade, mas que acabam sendo ações isoladas e efêmeras, já que não surgem de uma iniciativa conjunta daqueles que pensam e fazem a escola. Muitas vezes este lugar estelar ocorre como uma forma de resistência diante do silêncio ou da condena à invisibilidade vindas de políticas ou conduções que não valorizam o rol estratégico das bibliotecas.

Assim sendo, acreditamos que a formação de redes, relações de parceria que envolvam os acadêmicos e pesquisadores das universidades, professores, alunos e seus pais, diretores, assim como associações não-governamentais e instituições privadas podem ser mobilizadas a fim de gerarem muitos frutos, que vão do maior interesse pela leitura à visibilidade pública, chamando a atenção da sociedade para essa instituição que, geralmente fica escondida em algum canto da escola, delineando, assim, outra região de sentidos para a mesma.

É importante lembrarmos que uma atuação problemática e infrutífera nas bibliotecas não é exclusividade de profissionais não habilitados em Biblioteconomia/Ciência da Informação, já que muitos bibliotecários não estão preparados para atuar frente às particularidades da biblioteca escolar, que contém objetivos muito diferentes das demais bibliotecas. Muitas vezes, a concentração nas atividades de organização das estantes e empréstimo do acervo significa a não realização de outras, de "ações criativas que visam à formação de leitores e pesquisadores." (ALMEIDA JÚNIOR; BORTOLIN, 2009, p. 2005). Essa falta de criatividade na biblioteca escolar acarreta, segundo Almeida Júnior e Bortolin (2009, p. 215), a "invisibilidade desse centro de recursos e, por sucessão, esquecimento do livro, abandono da leitura, desprezo pela cultura e desinteresse pela informação."

Algumas outras "atitudes anti-usuário", apontadas por Silva, W. (2003) e outros autores como Almeida Júnior e Bortolin (2009), Maroto (2009), Silva (1998) etc, afastam a biblioteca escolar de seus sujeitos-leitores, tais como normas e horários muito rígidos que não se adequam às atividades escolares, impedindo ou restringindo o uso da biblioteca; preocupação excessiva com o silêncio, disciplina e arrumação; não-circulação do acervo e impedimento do acesso às estantes, ofuscando, assim, "a idéia de que as obras estão ali exatamente para que sejam consultadas" (SILVA, W., 2003, p.61). Tais atitudes não devem ser o foco da atuação de sujeitos-profissionais, pois a "organização, a disciplina, a observação do regulamento não devem ser vistos como os objetivos da biblioteca escolar, mas como condição para que ela alcance os seus reais objetivos, a saber, a promoção da leitura e a democratização do conhecimento registrado" (SILVA, W., 2003, p.64). Essa questão indicia 
uma concepção instrumentalista da biblioteca, onde, segundo Castán (apud BAJOUR, 2007, p. 1), "os meios se confundem com os fins, e evitando o debate de fundo, que deveria centralizar-se nas finalidades, no para que (e somente depois se responderia ao como) de uma biblioteca escolar de novo cunho." Além dessas atividades relativas à organização e funcionamento da biblioteca, é importante que apontemos aquelas concernentes à maneira como a leitura e a pesquisa são geralmente motivadas ou silenciadas. No caso da leitura, destacamos a esporadicidade e o autoritarismo que a marcam:

Na escola, em geral, a leitura nem sempre está em 'cartaz' e quando está, é apresentada em poucas 'sessões' e os 'ingressos' são oferecidos autoritariamente tendo como base o 'desejo da escola' e não o 'desejo coletivo'. Sendo assim, na maioria das vezes, não é possível considerar a escola como um espaço 'envolvente' e propício para a leitura. A leitura na escola ainda tem um ranço de didatismo. (MARTINS; BORTOLIN, 2006, p. 38)

Sendo assim, Ferreira (2009, p.70) considera que o modo como as atividades de leitura são realizadas na sala de aula afastam os alunos de textos diversos; além disso, os estudantes não são estimulados a lerem e frequentarem a biblioteca:

Justifica-se, então, que esse espaço escolar seja pouco visitado pelos alunos e concebido por eles como aborrecido, monótono. Há, então, um porquê para a resistência dos alunos em relação à leitura e para o descaso em relação ao ensino de literatura e à biblioteca escolar.

Ainda segundo o autor supracitado, em relação aos fatores que levam à rejeição da leitura, destacam-se a ausência de uma prática democrática na sala de aula (impedindo o diálogo e a reflexão), a desvalorização da biblioteca, o livro entendido como instrumento de transmissão de normas, o pouco contato com os textos em casa e a falta de conhecimento dos professores em relação às obras infanto-juvenis. É importante ressaltarmos, também, como uma das causas dessa rejeição, a concepção de leitura como hábito, termo que este cujo uso nos incomoda, pois se relaciona a uma ação mecânica e desprovida de reflexão, ainda que seja suscitada pelo prazer e desejo de ler. A partir desta região de sentidos, a leitura significaria um ato obrigatório e pouco fértil, exacerbado pela sua associação com punições e outras atividades cerceadoras e restritivas, como a de "estipular calendários (apenas uma ou duas vezes por semana) e fixar horários reduzidos" (MARTINS; BORTOLIN, 2006, p. 39), que podem afastar os sujeitos-leitores, impedindo a circulação da imagem que associa leitura e prazer, a qual poderia estar presente em práticas onde o aluno tivesse maior liberdade para ir à biblioteca, perder-se entre as estantes e degustar um livro que mais lhe tenha chamado a 
atenção. Tais questões indiciam a necessidade de ações estruturais, mais amplas e planejadas, que se insiram no projeto educacional e abordem a leitura de forma a não vê-la como mecânica, fechada, homogênea e autoritária, o que implica ir além do fornecimento de livros, como já dissemos anteriormente, já que "a simples distribuição de livros nas escolas não mudará, portanto, as práticas pedagógicas em relação ao uso de livros de literatura nem a apropriação e a construção de novos sentidos a partir da leitura." (PAIVA; BERENBLUM, 2009, p. 10).

Em relação à pesquisa escolar, observamos que a forma como ela vem sendo realizada não está colaborando para o desenvolvimento de um processo educativo interessante e criativo, posto que, segundo Pieruccini (2008, p. 42), ela é vista como "resposta mecânica a solicitações- quase sempre também mecânicas- dos professores". Sendo assim, retomando Campello (2003, p.19), marcamos que atualmente "observa-se que a biblioteca ainda está afastada do processo de aprendizagem por meio da pesquisa escolar", na medida em que esta vem sendo usada apenas para complementar notas, ou, como forma de recuperação, caso elas estejam abaixo da média escolar (ELLWEIN, 2006). Marcamos também a relação distante estabelecida entre o atendente, o aluno e a tarefa pedida pelo professor:

As crianças, de um modo geral, são tratadas como escolares. Dessa forma, nas bibliotecas estabelece-se um diálogo triplo: o atendente, a criança e o professor- este representado por uma folha de caderno na qual está especificada a pesquisa a ser feita. A relação nesse caso passa a ser a do atendente com a folha de caderno. São as palavras aí contidas que definirão a busca. Como esse atendente não é especialista em literatura infantil e, muito menos, em criança, vale-se da primeira enciclopédia ao alcance das mãos e confere se existe algum verbete que se aproxima do assunto apontado na folha de caderno. Ao pequeno protagonista no papel de pesquisador cabe fazer uma cópia para desincumbir-se de uma tarefa. Ele está ali para cumprir uma obrigação para ser aprovado. E como há muito mais obrigações a cumprir do que prazer a ser buscado, existem mais bibliotecas escolares do que infantis. E conforme o quadro econômico-social, nem mesmo existe a biblioteca escolar ou o que pode ser assim chamado. (MILANESI, 2002, p.57).

Ao ocuparem a posição de escolares, é associada aos sujeitos-alunos uma imagem estereotipada, pela qual eles teriam as mesmas preferências e interesses de leitura, atribuindo os mesmos sentidos ao que lêem; além disso, a partir dessa proposta de "roteirização" homogeneizadora (CORACINI, 1999), os sujeitos teriam que ler as mesmas obras que os demais, escrever exatamente o que se pede, repetir os sentidos veiculados pelos professores e o livro didático, não assumindo, assim, a autoria em suas produções. É importante ressaltarmos, ainda, que as bibliotecas não foram preparadas para atender a pesquisa escolar, 
que foi instituída legalmente na década de 1970, levando muitos alunos a procurarem as bibliotecas públicas que, no entanto, também não estão aptas a atendê-los, pois possuem orientação e estrutura muito diversa. Da mesma maneira, "os professores não foram preparados para lidar com essa nova exigência; a preparação não existia no currículo dos cursos formadores de profissionais como também não estava estruturada nas estâncias educacionais do Estado. É possível que uma ou outra iniciativa tenha ocorrido, mas não redundaram em uma prática comum" (ALMEIDA JÚNIOR, 2006, p. 98-99). Observamos que, com o advento da Internet, poucas mudanças ocorreram:

causando uma sensação de derrota naquele que pesquisa (aluno), no que solicita a pesquisa (professor), em que tenta orientá-la (bibliotecário) e, ainda, nos que, quando interessados, acompanham a pesquisa (pais e/ou responsáveis). (ALMEIDA JÚNIOR; BORTOLIN, 2009, p. 213).

Quando se fala em pesquisa escolar na Internet, é preciso considerar que há realidades muito distintas de acesso: "De um lado há uma parcela de estudantes que possui equipamentos, conhecimentos e habilidades para acesso às informações contidas na web. Do outro lado estão os estudantes desprovidos até de material impresso para a pesquisa." (BICHERI; ELLWEIN, 2006, p. 106). Afetados pela ideologia que legitima as novas tecnologias de informação, como a Internet, os sujeitos-alunos julgam que os sentidos em circulação na rede são corretos e os únicos possíveis, recortando e imprimindo, sem ao menos ler, os primeiros arquivos encontrados que correspondam ao tema proposto. As facilidades oferecidas pelo meio eletrônico tornam mais fáceis as operações de pesquisa, cópia e seleção do que será impresso e entregue ao professor, estruturando a aprendizagem em redes de paráfrases que impedem o surgimento do novo, o que nos faz concordar com Bicheri e Ellwein (2006), quando afirmam que não basta apenas saber manusear as tecnologias, mas valer-se de suas funcionalidades para tecer uma relação mais criativa com o saber.

Analogamente, constituir uma biblioteca com um ambiente agradável e bem iluminado, dotada de um acervo diversificado e móveis adequados ao uso que deles será feito não significa, necessariamente, criar um espaço polissêmico que concretize a concepção de biblioteca em que acreditamos. A existência destes recursos pode ser muito profícua, contudo cabe observarmos que, muitas vezes, bibliotecas menos equipadas, mas que contam com profissionais abertos a práticas que se distanciem daquelas tradicionalmente realizadas na sala de aula, podem configurar-se de maneira mais próxima da que é considerada ideal, ao serem postas em movimento por aqueles que, "mesmo não tendo formação na área, valorizam o trabalho com a leitura, são dedicados e realizam suas atividades com interesse e competência, 
e quando tem oportunidade ingressam no curso de graduação em biblioteconomia, para continuar atuando no espaço da biblioteca escolar."

Isso nos faz reforçar a importância da formação de profissionais que contribuam para a superação das atividades de pesquisa como cópia e leitura como mero processo de decodificação do que "o autor quis dizer", associadas ao uso da biblioteca como se esta fosse um mero apêndice, depósito ou lugar de castigo. Diante da forma infrutífera de lidar com a leitura e a pesquisa escolar, tanto em materiais impressos quanto eletrônicos, é preciso uma mudança de postura por parte dos professores e bibliotecários, abrindo espaço para práticas discursivas mais críticas, criativas e questionadoras, como viemos sugerir, apoiadas nos pressupostos teóricos da Análise do Discurso francesa.

Inferimos que as atividades educativas autoritárias e parafrásticas, centradas exclusivamente no livro didático e realizadas no âmbito da escola e sua biblioteca "tradicional" (quando esta existe), tendem a serem vistas como desinteressantes e monótonas, por sujeitos-navegadores das ágeis, múltiplas e interativas redes eletrônicas, que carregam a promessa de liberdade para o sujeito que nelas navega. É importante ressaltarmos também que, na ausência de uma prática educacional mais crítica e polissêmica, que leve em conta a constituição dos saberes, e não a sua mera reprodução, instigando os alunos a interpretarem os discursos materializados no suporte impresso e, também, digital, os alunos acabam usando a Internet da mesma maneira infrutífera que as enciclopédias impressas foram e ainda continuam sendo utilizadas: copiando os fragmentos (agora dispersos pela rede) a serem entregues ao professor (não mais escritos à mão ou datilografados, mas impressos), o que também é apontado por Garcez (2009, p. 21): “mesmo com todas as informações disponibilizadas na Internet, os alunos, não sabem fazer pesquisa diferente da mera cópia, e agora no atualizado recorta-e-cola, que os processadores eletrônicos de textos tornou possível."

Compreendemos que, por meio de tais práticas, os sujeitos-alunos acabam não ocupando a posição de autor (ORLANDI, 1988), nem a função-leitor (PACÍFICO, 2002), que o permitiriam assumir a responsabilidade pelo seu dizer e duvidar da transparência da linguagem, buscando compreender a constituição dos sentidos e realizar uma leitura mais polissêmica, em um contexto marcado pela "superabundância textual cuja oferta ultrapassa a capacidade de apropriação dos leitores" (CHARTIER, 2002, p. 20). Por conseguinte, os sujeitos acham-se: 
numa situação em que tudo lhes é estranho, parecendo marinheiros sem bússola, lançados à deriva nos oceanos informacionais (e do conhecimento). Em decorrência e sob tais circunstâncias, os atos de conhecer e de significar encontram-se afetados diretamente, demandando ações visando sua requalificação e reafirmação nos contextos contemporâneos, dentre as quais se inclui uma nova abordagem da biblioteca escolar. (PIERUCCINI, 2008, p.44)

Por fim, destacamos que, a partir das práticas restritivas citadas, a Internet seria vista, pelos sujeitos-alunos que nela navegam, apenas como um repositório de informações prontas, acabadas, verdadeiras, que podem ser copiadas, recortadas, sem se levar em conta o viés político e ideológico que constituem os dizeres, a incompletude e heterogeneidade, que reclamam gestos de interpretação, uma leitura que vai além do literal. Neste contexto, ao serem realizadas práticas educativas mais polissêmicas, pode ser construído um espaço discursivo plural e movimentado, de produção de sentidos outros, no qual é dada ao sujeito a possibilidade de tecer o novo, "possibilitando-lhe agir no mundo e não ser apenas um receptor de sentidos estereotipados" (ROMÃO; PACÍFICO, 2006, p. 10). A seguir, falaremos sobre essa outra maneira de discursivizar as práticas educativas e a biblioteca escolar.

\subsection{Outros sentidos sobre biblioteca escolar: nos meandros do discurso político- científico}

A cabeça da gente é uma só, e as coisas que há e que estão para haver são demais de muitas, muito maiores diferentes, e a gente tem de necessitar de aumentar a cabeça, para o total. (ROSA, 1965, p. 236).

Nesta seção, buscamos "aumentar a cabeça", afastarmo-nos um pouco daquela representação de biblioteca escolar sobre a qual viemos falando até aqui, marcada historicamente por restrições e dificuldades, a fim de percorrermos outras veredas de sentidos, abordando como os discursos oficiais e científicos enunciam sobre a biblioteca escolar, a partir do lugar de autoridade que lhes é conferido, atribuindo-lhe sentidos de valorização que fazem com que ela deixe de ser falada tal como se apresenta no cotidiano escolar brasileiro, seus problemas, descaso e silenciamento ao quais está acorrentada.

Observamos, assim, a repetição dos sentidos pelos quais a biblioteca é concebida a partir de um lugar de importância na educação, como podemos observar na Declaração política da IASL sobre bibliotecas escolares, que a considera "essencial", "parte vital desta educação obrigatória e gratuita" ou ainda "factor de desenvolvimento da qualidade educativa" (INTERNATIONAL ASSOCIATION OF SCHOOL LIBRARIANSHIP, 1993). Em outros 
documentos oficiais, como o Manifesto IFLA/UNESCO para biblioteca escolar, essa instituição é discursivizada de modo semelhante, ao ser apontada como "parte integral do processo educativo" (INTERNATIONAL FEDERATION OF LIBRARY ASSOCIATION AND INSTITUTIONS, 1999, p. 2). Ressaltamos que estes dois documentos são extensamente parafraseados, especialmente no discurso científico, inserindo a biblioteca escolar em um lugar de prestígio (nem sempre ocupado na sociedade), pelo qual, a partir do cumprimento de determinadas funções e papéis, ela estaria imaginariamente apta a contribuir para a formação de um "cidadão responsável”, um "membro útil” da sociedade da informação; tais sentidos indiciam e reforçam a maneira utilitária como é falada comumente a biblioteca escolar, normatizando a serventia de frequentar este espaço, a fim de ocupar o papel que é esperado que se cumpra frente a um mundo globalizado e que preza a produtividade, silenciando-se assim os efeitos de prazer que poderiam suscitar o contato com a biblioteca e os livros, outros materiais e atividades que ela pode viabilizar.

No discurso da Ciência da Informação circulam os sentidos de importância da biblioteca, também veiculados pelos documentos oficiais, por meio dos quais ela é tida como "recurso indispensável para o desenvolvimento do processo ensino-aprendizado e formação do educando" (AMATO; GARCIA, 1998, p.11), Marcamos que uma série de outros autores fazem circular estes sentidos, presos a uma rede de paráfrases; por meio delas, eles são naturalizados, tomados como verdadeiros, o que pode levar a um apagamento de sentidos outros, mais questionadores, que os desconstruam e ressignifiquem, de acordo com o contexto sócio-histórico em que aparecem. Nessa formação discursiva, a biblioteca escolar deixa de ser falada como um depósito inerte de livros e outros materiais, para ser considerada um espaço de ação pedagógica, um centro de informação e cultura formado por vários tipos de documentos e diferentes suportes informacionais, ou ainda "um espaço de criação e de compartilhamento de experiências, um espaço de produção cultural em que crianças e jovens sejam criadoras e não apenas consumidoras de cultura." (CAMPELLO, 2002, p.22). Outros autores discursivizam a biblioteca escolar como um "centro educativo e cultural" (FURTADO, 2004, p. 8), "centro do fazer educativo" (NERY, 1998, p. 56), ou ainda, "centro ativo de aprendizagem" (HILLESHEIM; FACHIN, 2003, FRAGOSO, 2005), evocando a intensa repetição do termo "centro", fazendo um contraponto com a posição periférica que vem sendo historicamente ocupada pela biblioteca.

A partir dessa região da memória discursiva, a biblioteca é revestida de um caráter dinâmico, orgânico e plural, sendo tomada como um "organismo vivo que emana para toda a comunidade escolar possibilidades distintas de conhecer, de sedimentar o que já se sabe, de 
refletir e ampliar a compreensão do mundo dos alunos" (SILVA, 2009, p. 118), um "centro dinâmico de informação da escola" (ANTUNES, 1998, p. 171), "centros dinámicos, con un nuevo espacio-entorno y un innovador concepto de servicios" (CUEVAS CERVERÓ, 2007, p. 174). Nesse ambiente tão movimentado, a diversidade estaria presente e seria bem-vinda, já que a biblioteca é um "espaço social onde convivem pessoas de diferentes faixas etárias, de vários níveis econômicos, diversas escolaridades e credos, várias raças, variada tipologia de profissionais, além de segmentos da comunidade em geral"' (ELY, 2003, p.46).

Posto isto, pudemos observar que, para que seja possível ocupar este outro lugar discursivo, é tecido um contraponto entre a biblioteca "tradicional", vista como arcaica, restrita, estática, não desejável (que a nosso ver ainda está longe de ser totalmente superada), e essa biblioteca escolar da "sociedade da informação", que deseja se impor como um lugar de disseminação cultural, de "encontro de pessoas, pipocar de teclados de notebooks e dispersão de livros" (ARENA, 2009, p. 162), de circulação de diferentes sujeitos, sentidos, serviços e recursos (incluindo os eletrônicos), delineando assim uma imagem considerada "ideal" de biblioteca escolar. Assim sendo, a biblioteca não pode se restringir a um papel meramente didático-pedagógico, a apoiar o programa do professor, devendo ir além (PERROTTI, 2006), explorando sua multiplicidade, as suas várias dimensões, citadas por Ely (2003), a saber, social, informativa, criativa, pedagógica e recreativa; dimensões estas que significam as funções que deveriam ser desempenhadas pelas bibliotecas, de acordo com a International Association of School Librarianship (1993).

Vários autores, como Fragoso (2002) e Silva (2009), retomam estes sentidos, apontando diferentes ações a serem desempenhadas pelas bibliotecas, como o atendimento às necessidades dos alunos, professores e outros membros da comunidade escolar, orientação nas consultas, leituras e utilização da biblioteca, incentivo ao pensamento crítico e reflexivo, disponibilização de diversos recursos e serviços, promoção da interação entre sujeitosprofessores, bibliotecários e os alunos, etc. Segundo Silva (2009), são destacadas como importantes funções das bibliotecas a formação de leitores e o despertar do gosto pela leitura, ainda que nem sempre seja abordado o que é necessário para tanto. Marcamos que os Parâmetros Curriculares Nacionais também apontam a importância da leitura e da biblioteca que deveria promovê-la. (BRASIL, 1997), em prol de uma educação mais profícua.

Procurando analisar as funções das bibliotecas de forma mais ampla, Perrotti (2006), Arena (2009, p. 165), dentre outros, consideram que elas vão além do apoio, complemento às ações de leitura e pesquisa desenvolvidas na sala de aula, visto que estariam mais relacionadas “à concepção de espaço da cultura, da produção de leitura, da produção de textos escritos e do 
porto de partida para a navegação pelo mundo virtual". Quando a biblioteca incorporar os computadores e impressoras, ela passará a ser também "um centro de produção de textos, originais ou coletados pela rede, escritos pelos alunos ou impressos pelos navegadores, para dispersão pelos corredores e pelas salas de aula. Em vez de a sala de aula invadir a biblioteca, a biblioteca escolar começará invadir as salas de aula." (ARENA, 2009, p. 166). Consideramos que tal relação biblioteca-sala de aula, mediada pela rede, ainda faz parte de um grupo seleto, mas vem se mostrando como uma perspectiva interessante de bibliotecas mais flexíveis, atraentes e plurais, que não abram mão dos gestos de leitura de um livro ou outra obra impressa, mas que inaugurem outros, integrando sujeitos e sentidos, na biblioteca e nas redes da Internet. Assim sendo, segundo Silva e Bortolin (2006, p. 12), as mudanças na concepção de biblioteca de que falamos são suscitadas pelas novas tecnologias de informação e comunicação:

As bibliotecas são tradicionalmente percebidas como um espaço de organização e manutenção de livros; porém, à medida que novos suportes de informação e documentação vão surgindo, elas precisam, progressivamente, alterar sua forma de atuação na sociedade.

A partir de tais modificações, que abrangem a abertura às novas tecnologias, a biblioteca poderia ingressar na chamada sociedade da informação, conforme nos conta Fuentes Romero (2006, p. 30): "la biblioteca escolar es para los alumnos la puerta de entrada a la sociedad del conocimiento y de la información." Nessa perspectiva, a biblioteca teria a função de se adequar à essa sociedade, inserindo crianças e jovens em seu âmbito e também promover a chamada competência informacional (information literacy- IL), que "abrange desde os processos de busca da informação para construção do conhecimento pelas habilidades em tecnologia da informação até o aprendizado independente, por meio da interação social dos sujeitos. A IL tem por objetivo formar indivíduos que aprendem por toda a vida" (QUEIROZ, 2006, p. 25), através de um processo educativo independente, crítico, ativo e investigativo. Consideramos que estas competências, ao invés de se configurarem de maneira mecânica, devem auxiliar na construção de conhecimentos de forma mais ampla e criativa, colaborando para práticas de ensino/aprendizagem mais plurais.

O estímulo à aprendizagem contínua também é mencionado como uma função da biblioteca, pela International Federation of Library Association and Institutions (1999, p. 1): "A BE habilita os estudantes para a aprendizagem ao longo da vida"; e também pela International Association of School Librarianship (1993, p. 3): “As capacidades apreendidas pelo estudante através da biblioteca dotam a criança com os meios que lhe possibilitam 
adaptar-se a uma variedade de situações e possibilitam a educação permanente ao longo da vida, mesmo em situações adversas". Tece-se, assim, um paralelo entre as formas de ensino tradicionais e as supostamente vigentes e apoiadas na biblioteca escolar, tidas como mais amplas: "todos os sistemas de educação devem também ser estimulados a alargar os contextos de aprendizagem à biblioteca escolar não os reduzindo ao professor e aos manuais." (INTERNATIONAL ASSOCIATION OF SCHOOL LIBRARIANSHIP, 1993, p.3). Outro aspecto frequentemente enunciado sobre a biblioteca é a necessidade de estimular a criatividade e a construção do conhecimento, (ANTUNES, 1998), que se relaciona a um modelo de educação que consideramos mais profícuo, abrindo espaço à polissemia e aos sentidos mais plurais.

São também frequentes as recomendações acerca do espaço e dos recursos que caracterizariam uma biblioteca escolar, os quais não correspondem em nada, ao panorama apresentado na seção anterior, marcado pela inexistência ou escassez de recursos mínimos que permitam o funcionamento de uma biblioteca. Em relação ao espaço, destacam-se a necessidade de que ele seja planejado, conforme apontam Fragoso (2005) e Furtado (2004), no que diz respeito à sua amplitude, condições de iluminação, temperatura e umidade, disposição dos móveis e decoração, que deveriam estar de acordo com os sujeitos-leitores que frequentarão a biblioteca. Quanto ao tamanho da biblioteca escolar, aponta-se a necessidade de que haja espaço suficiente para acomodar o acervo atual e suas futuras ampliações e também condições para receber os alunos, ao menos uma classe, segundo Lopes (1998) e Ely (2003). Também são destacadas a importância de que não haja umidade e que o ambiente seja bem iluminado e ventilado, o que o torna um espaço aprazível e adequado à conservação das obras.

A respeito do mobiliário e recursos disponíveis, além das mesas, cadeiras, estantes, armários, escrivaninhas, etc., considera-se interessante que haja materiais como quadro de feltro, lousa com cortina, tapetes, esteiras, almofadas, varal para exposições, baú com fantasias, etc. (LOPES, 1998). Além desses recursos, Nery (1998, p. 56) aponta outros: "estantes baixas, ou, pelo menos, ao alcance dos menores. Cestos de livros, um canto descontraído para leituras na própria biblioteca. Mesa ou carteira com cadeira para momentos de ler e escrever, ler e desenhar." Uma questão sobre o mobiliário comumemente abordada, por autores como Silva (2009), é a sua segurança, resistência, praticidade e comodidade para os leitores, além da presença das novas tecnologias no planejamento da biblioteca escolar, incluindo, por exemplo, condições para o acondicionamento de computadores; essa 
necessidade de um espaço onde se possa explorar as tecnologias é destacada também pela International Association of School Librarianship (1993).

Segundo Perrotti (2006), é relevante também que o ambiente da biblioteca escolar permita a autonomia dos sujeitos, o que acarretaria outra relação entre eles e a biblioteca, pois ela não seria mais um lugar de imposição de leituras, fechado para sua circulação, impedindo diferentes experiências com as obras e afetando o despertar do gosto pela leitura. Na literatura científica e nos documentos oficiais encontramos diversas recomendações referentes à estrutura de bibliotecas escolares, a fim de que elas se tornem atraentes, acessíveis e confortáveis, suscitando o prazer em seus frequentadores. A importância de que a biblioteca seja agradável é apontada por Ely (2003), Maroto (2009) e Silva, Ferreira e Scorsi (2009). Também é lembrada, por Amato e Garcia (1998, p. 15), a necessidade de "um ambiente adequado à pesquisa, ao estudo, à recreação, à orientação pessoal, aliados a uma programação intensa". Por fim, concordamos com Silva, Ferreira e Scorsi (2009, p. 57-58), quando elas consideram a necessidade de que o espaço seja sempre reformulado, acompanhando as mudanças:

os espaços da escola não devam ser locais paralisados e nem paralisantes. Ao contrário, eles têm de acompanhar o dinamismo próprio do tempo em que vivemos. Devem ser modificados, alterados, compostos, sempre que se perceber necessidades de mudanças. Às imagens que neles se encontram e as que aí podem permanecer por longo tempo, faz-se necessário somar outras, igualmente impactantes, e relativas aos temas em desenvolvimento.

Já a respeito do acervo, é atestada a necessidade de que ele seja variado, abrangendo todo tipo de recursos informacionais, como nos diz Perrotti (2006, p. 22), "do papel ao equipamento eletrônico", incluindo jogos, brinquedos, etc. Essa necessidade também é apontada por Kuhlthau (2004), International Federation of Library Association and Institutions (1991), International Association of School Librarianship (1993), Furtado (2004), Beauchamp e Silva (2007) e Amato e Garcia (1998). Também é mencionada a necessidade de se contar com obras de diferentes gêneros, como romances, contos, poesias, história em quadrinhos, enciclopédias, jornais, revistas, almanaques, dentre outros, além dos trabalhos produzidos pelos próprios alunos. (BRASIL, 1997). Além disso, marca-se a necessidade de que sejam estabelecidas políticas de seleção e aquisição do acervo, visando a atender, de forma mais satisfatória, aos anseios da comunidade escolar (FRAGOSO, 2005, FURTADO, 2004, CAMPOS; BEZERRA, 1998). Posto isto, pelo viés da teoria do discurso, consideramos que, lançando mão de uma diversidade de portadores de texto- entendidos por nós como objetos em que se materializam um ou mais discursos construídos sócio-historicamente-, 
suportes informacionais e atividades amparadas por uma nova concepção de leitura, escrita e apreensão dos sentidos, o profissional da informação, juntamente com os educadores, poderão fazer da biblioteca, um lugar privilegiado para um processo de ensino/aprendizagem que permita ao sujeito-escolar ser e significar. Assim sendo, a escola e sua biblioteca escolar deveriam proporcionar uma vasta gama de materiais, bibliográficos ou não, a fim de possibilitar o acesso ao arquivo- memória institucionalizada, que, segundo Orlandi (2006a, p. 22), "é aquela justamente que fica disponível, arquivada em nossas instituições e da qual não esquecemos"- e à toda uma rede de discursos, ao interdiscurso (PÊCHEUX, 1997), o já- dito que sustenta cada tomada da palavra e a interpretação, considerada a compreensão de como o objeto simbólico produz sentido.

É importante ressaltarmos que, apesar de se reconhecer a importância de que haja uma diversidade de obras e suportes na biblioteca, a mesma não é atendida pelos órgãos que a legitimam, visto que, em relação ao Programa Nacional Biblioteca da Escola, "as obras distribuídas incluem textos em prosa (novelas, contos, crônica, memórias, biografias e teatro), obras em verso (poemas, cantigas, parlendas, adivinhas), livros de imagens e livros de histórias em quadrinhos." (BRASIL, c2009), predominando, assim, as obras impressas que, conforme consideramos, "precisam fazer parte da vida do aluno, para que pertençam não somente ao acervo escolar e cultural, mas ao imaginário, à sua história de leitura, ou seja, à sua biblioteca vivida" (FERREIRA, 2009, p. 89-90). Tal perspectiva está em sintonia com a concepção de uma biblioteca viva e atuante no espaço escolar, cujo acervo não é o fim, mas apenas o início de uma série de possíveis ações em prol da leitura e aprendizagem mais férteis. Assim sendo, como nos diz Arena (2009, p. 162), "não bastam espaços e livros guardados para caracterizar a existência de uma biblioteca escolar; não são os objetos físicos que dão a ela a existência e a vida; nem sempre é somente com eles que o diretor pode afirmar que há biblioteca na escola"; proposição esta com a qual concordamos plenamente, pois implica considerarmos uma biblioteca em movimento e o trabalho com a linguagem.

Ainda quanto ao acervo, é ressaltada sua função de oferecer suporte aos conteúdos ensinados na sala de aula e também de satisfazer a curiosidade e o gosto pessoal dos alunos e outros sujeitos da comunidade escolar; sendo assim, ele pode abranger: "acervo infantojuvenil de literatura, livros científicos e periódicos para atendimento de crianças e jovens que frequentam a escola; acervo para o grupo docente; material de referência; acervo para a comunidade escolar como um todo e multimeios (CDs, DVDs, etc)" (SILVA, 2009, p. 129): ou seja, acervo diversificado quanto aos gêneros e suportes e que deve ser ampliado continuamente e organizado de maneira a facilitar a busca por uma leitura, e não desestimulá- 
la (BRASIL, 1997). Ainda segundo Silva (2009), no caso das bibliotecas escolares que atendam a um público infantil, podem-se adotar, na organização do acervo, princípios diferentes das classificações tradicionais que levem em conta os sujeitos-leitores e suas necessidades. Uma questão muito recorrente nas obras com as quais tivemos contato refere-se à necessidade de que a biblioteca escolar deixe de ser um órgão isolado da escola e da sociedade e participe das discussões pedagógicas, assumindo assim um papel ativo nestes ambientes, ampliando seu escopo de atuação, visando a "uma ação pedagógica integrada entre a biblioteca e a sala de aula, e entre a biblioteca e a comunidade escolar". (SILVA, 2009, p. 116) Esta concepção é aclamada por muitos teóricos, como Perrotti (2008, p.2), para o qual:

O compromisso com uma biblioteca ativa, inventiva e participativa implica também criação de vínculos fortes com o meio em que ela se encontra. Nesse sentido, torna-se necessário não só levar a biblioteca à comunidade, mas também trazer essa e sua memória, suas histórias, suas realizações significativas para dentro da biblioteca. Uma instituição distante não cria elos fortes e duradouros com seu público.

Por essa ótica, o trabalho em conjunto, de bibliotecários, professores e demais membros da comunidade acarretaria muitos benefícios para a aprendizagem, melhorando o desempenho dos alunos. (INTERNATIONAL FEDERATION OF LIBRARY ASSOCIATION AND INSTITUTIONS, 1999). Também é tido como fundamental o envolvimento dos alunos no processo de dinamização da biblioteca (MAROTO, 2009). Tal interação entre toda a comunidade escolar é vista como essencial para que ela não seja apenas mais um orgão burocrático, conforme Campos e Bezerra (1998, p. 93): “criada de cima para baixo, sem um envolvimento maior dos educadores, sem corresponder a interesses e necessidades vivenciados, ela pode tornar-se um equipamento a mais, de existência morna e burocrática"

Para que essa atuação conjunta dê frutos, é necessário que ela seja planejada, conforme nos conta Almeida Júnior e Bortolin (2009), Maroto (2009) e Nery (1998). Assim sendo, em todas as decisões e atividades realizadas, é importante dar voz aos sujeitos, para que se encontre a melhor maneira de atender as suas necessidades, constituindo-se "um espaço democrático mesmo, de promoção da leitura, de discussão e de difusão e socialização de experiências.” (MAROTO, 2009, p. 79). Observa-se que o planejamento de atividades de leitura e pesquisa unindo professores e funcionários da biblioteca é de extrema importância para que ela ganhe espaço no projeto pedagógico e na grade horária, fazendo com que os alunos tenham oportunidades de frequentá-la e desenvolverem diversas atividades em seu âmbito. Frisamos que o sucesso dessas atividades realizadas na biblioteca depende não apenas 
do planejamento e estabelecimento de parcerias, mas também do trabalho de um funcionário qualificado, o que é confirmado por Fragoso (2002, p.128):

De nada serviria uma bela biblioteca escolar, com espaço físico e acervo adequados às necessidades escolar se, para exercer as funções e cumprir seus objetivos, não estiver em seu comando um profissional consciente, com sensibilidade e habilitações básicas para manter esse espaço de cultura e informação bem azeitado e atraente, onde a técnica é utilizada para produzir conhecimento.

É importante ressaltarmos que, nos documentos oficiais internacionais e também em grande dos científicos, o bibliotecário é considerado o profissional adequado para atuar na biblioteca escolar: "o bibliotecário escolar é o membro profissionalmente qualificado, responsável pelo planejamento e gestão da biblioteca escolar". (INTERNATIONAL FEDERATION OF LIBRARY ASSOCIATION AND INSTITUTIONS, 1999, p. 3). A partir desta ótica, considera-se que "uma boa biblioteca escolar com um bibliotecário qualificado é o maior factor de desenvolvimento da qualidade educativa." (INTERNATIONAL ASSOCIATION OF SCHOOL LIBRARIANSHIP, 1993, p.4). O perfil desejado para esse profissional bibliotecário é muito discutido, por autores como Amato e Garcia (1998) e, também, Campos e Bezerra (1998), sendo frequentes as menções à criatividade, interesse, conhecimentos de organização de bibliotecas, capacitação para atender aos sujeitos-leitores, conhecimento sobre a realidade da escola, buscando "outros 'espaços' e outras práticas de atuação e de intermediação entre a biblioteca e o leitor; entre o leitor e o contexto; entre a técnica e a promoção da leitura." (MAROTO, 2009, p. 132). O bibliotecário escolar é visto também, por Rigoleto e Di Giorgi (2009, p. 229), como um educador, apto a "despertar o interesse do leitor, multiplicar as práticas de leitura e oferecer a diversidade de material [...]". Maroto (2009) também frisa a necessidade de que esse profissional esteja preparado para o exercício da leitura e sua difusão, o que implica que ele também seja, além de dinâmico, um leitor, que ele goste de ler, conforme nos diz Silva (2009) e Fragoso (2002).

Alguns teóricos, como Silva, Ferreira e Scorsi (2009, p. 62) apontam que, a partir de uma nova perspectiva para o trabalho bibliotecário, a biblioteca não precisa nem pode ser um lugar de excessiva ordenação, normatização e resguardo, mas um "lugar para as escolhas de cada leitor, para as indicações deste a outro, para conversas em torno dos livros", delineandose, assim, outras regiões de sentido para essa instituição. Além disso, sob essa ótica, o bibliotecário se abre a novas atividades "relacionadas com a promoção da leitura, atividades de extensão cultural para a comunidade, recreação, lazer etc”. (FURTADO, 2004, p. 8), ultrapassando-se, assim, o foco apenas no empréstimo de obras e criando "em torno das ações 
de leitura e pesquisa um clima de liberdade e ludicidade" (ALMEIDA JÚNIOR; BORTOLIN, 2009, p. 206). A partir disso, ressaltamos uma grande variedade de atividades que são propostas, por Perrotti (2006), Campos e Bezerra (1998), Guinzelim, Girotto e Souza (2009), Santos e Souza (2009), Almeida Júnior e Bortolin (2009), Antunes (1998) e Fragoso (2002), para serem realizadas no âmbito da biblioteca, como, por exemplo, a tradicional Hora do Conto, onde se podem utilizar diversos recursos como fantoches, dedoches, gravuras, etc; conversa com autores e outros profissionais; círculo de leitores; saraus literários e gincanas culturais; modelagens, dobraduras e maquetes; brincadeiras; audição de autores gravados; dramatizações; mostras temáticas, exposições de produções dos sujeitos-alunos; projeção de filmes, e outras que "ousem recriar sempre e sempre os jogos verbais que a linguagem possibilita." (NERY, 1998, p. 59), ou seja, que coloquem em movimento sujeitos e sentidos, contribuindo para "a aproximação entre crianças e livros, estimulando a leitura" (CAMPOS; BEZERRA, 1998, p. 90).

Ressaltamos que, através das parcerias com professores, pais, a biblioteca pública, livrarias e espaços culturais da cidade, dentre outros membros da comunidade, podem ser propostas atividades interessantes que superem a mesmice daquelas focadas na aula expositiva do professor e no livro didático (ELY, 2003), por meio da formação de redes, das quais nos fala Perrotti (2006), suscitando outros sentidos para esta instituição:

rompendo aquela imagem de instituição parada à qual recorremos apenas quando temos dúvidas pontuais a dirimir ou trabalhos escolares a realizar. Núcleo de produção de textos, centro de estudos de determinadas disciplinas ou temas, palco de debates, promotora de concursos literários etc., a biblioteca pode ser o eixo de todas essas atividades, sempre pensadas e executadas pela comunidade escolar, e não apenas pelo bibliotecário. (SILVA, W., 2003, p. 106)

$\mathrm{Na}$ tentativa de romper com os sentidos sobre biblioteca considerados "tradicionais", que a associam a uma postura estática e arcaica, aproximando-se, assim, da perspectiva que viemos abordando nesta seção, surgem outras formas de discursivizar esta instituição, buscando marcar, ao menos na ordem da língua, as mudanças almejadas e que ainda nos parecem distantes; a partir disso, surgem denominações como CRA (Centro de Recursos para Aprendizagem) e Estação do Conhecimento, das quais falaremos, respectivamente, a seguir. O Centro de Recursos para el Aprendizaje (CRA) ou Centro de Recursos Multimediales é um modelo hispanoamericano considerado essencial para a educação, no âmbito da sociedade do conhecimento que reclama um novo modelo de biblioteca escolar (CUEVAS CERVERÓ, 2007), diferente da tradicional idéia de biblioteca como um lugar isolado da dinâmica da 
escola, destinado apenas a organizar e conservar livros, conforme nos conta Marzal e Cuevas Cerveró (2007). A partir disso, pensou-se nesse novo modelo (CRA) que não anula, mas enriquece a noção tradicional ao integrar os recursos eletrônicos, a dimensão educativa, o principio de aprendizagem autônoma e a formação ao longo da vida. Caracterizado pela existência de diversos recursos e serviços de acordo com o projeto pedagógico, no qual deverá estar incluído e não ser visto como seu complemento, o CRA:

es el espacio de carácter pedagógico que contribuye de manera permanente a la innovación educativa. Reúne una variada gama de recursos de información en diversos soportes (bibliográficos, electrónicos, y audiovisuales, entre otros) organizándolos en función a los requerimientos del proyecto curricular del centro poniéndolos a disposición de los usuarios, alumnos y profesores, a través de sus variados servicios. (MARZAL; CUEVAS CERVERÓ, 2007, p. 9).

Assumindo a função de biblioteca educativa, um "novo espaço educativo dinâmico" (CUEVAS CERVERÓ, 2007, p. 178, tradução nossa), o CRA visa à formação, informação, entretenimento, intercâmbio e conhecimento. Sob esta nova ótica, afirma Milanesi (2002, p.77): "a biblioteca para exercer a sua função, deixa de ser o acervo milenar passivo e passa a ser um serviço ativo de informação". De forma semelhante, as Estações do Conhecimento são caracterizadas por uma pluralidade de recursos, sentidos e sujeitos, conforme nos conta Perrotti e Verdini (2008 p. 18):

Estações do Conhecimento constituem-se de materialidade, da reunião
orgânica e criteriosa de recursos informacionais diversos (livros, CDs,
DVDs, jornais, revistas, computadores, acervos de fotos, de memória local),
de coleções informacionais devidamente organizadas e tratadas, por outro
lado, constituem-se, sobretudo, de imaterialidades, de relações de sujeitos
com os significados e as linguagens culturais, de intercâmbios simbólicos, de
processos socioculturais múltiplos, devidamente desenvolvidos e que
constroem saberes conceituais e procedimentos referentes às próprias
informações, como, por exemplo, saber pesquisar, saber definir caminhos de
busca, localizar, selecionar, organizar informações; saber avaliar, explorar,
usar os múltiplos recursos disponíveis tanto para informar-se como para
informar; saber contextualizar associar conexões entre conteúdos, suportes,
linguagens, num processo de diálogo fértil e fecundo que constitui tantos os
sujeitos como o próprio conhecimento.

Ganham destaque nas Estações do Conhecimento não apenas uma nova configuração que reúne diferentes mídias e processos educativos e culturais, mas também a articulação de recursos pré-existentes, no âmbito da escola e fora dela, como bibliotecas escolares, salas de leitura, laboratórios de informática, etc., "organizando-os em redes, tramas, processos abertos e dinâmicos, no qual cada elemento continua mantendo sua identidade, mas ao mesmo tempo, 
transformando-a, ampliando-a, fortalecendo-a", facilitando, assim, as ações. (PERROTTI; VERDINI, 2008, p. 20). Contudo, mais do que a reunião de recursos, são necessários projetos que os viabilizem, pois não é possível agregar todos em único lugar, eles se completam, mas nunca são totais. É importante observarmos que, apesar de haver um certo consenso em relação a muitos aspectos que delineariam uma concepção tida como ideal de biblioteca escolar, não é possível existir um modelo fechado, rígido, visto que:

Sem dúvida, os projetos de biblioteca escolar a definir haverão de estar atravessados em cada caso pelas características sociais, hábitos culturais, tradições que fazem parte da vida da comunidade escolar e do entorno mais imediato rumo à atividade pedagógica e cultural que a escola irradia. Nesta trama há de ver se diversos sujeitos envolvidos, que desde diferentes posições participarão do convite da biblioteca. [...] O diálogo escolabiblioteca-comunidade é cotidiano e nesse diálogo do dia-a-dia configuramse linhas de sentido que dificilmente poderíamos preanunciar, planejar com antecipação, prever. Na verdade, trata-se de construir modelos o suficientemente flexíveis que nos permitam reconhecer estas variáveis contextuais como parte da vida mesma da biblioteca e não como exceção ao modelo, como déficit ou como carência. [...] Muda o contexto e mudam as demandas e acho que é o caráter necessariamente flexível dos projetos de biblioteca os que porão a sensibilidade necessária para responder a essas diferenças. (BOMBINI, 2007, p. 1-2)

Ressaltamos, apoiando-nos em Fuentes Romero (2006, p.22), que essas novas denominações de biblioteca referem-se à biblioteca escolar de sempre, mas adaptada aos novos tempos: "se pude llamar biblioteca escolar, centro de recursos, centro de recursos multimedia, centro de documentación curricular, mediateca etc. pero siempre nos estaremos refiriendo a la misma idea". Consideramos que uma biblioteca escolar mais dinâmica, formada por uma variedade de recursos movimentados por atividades educativas, lúdicas e de leitura, pode inaugurar novas maneiras de aprender, mais interessantes e polissêmicas, aproximando os sujeitos de diferentes linguagens, sentidos e também outros sujeitos, inserindo-se nos jogos de construção e interpretação da linguagem, superando, assim, práticas rígidas e desestimulantes encontradas frequentemente nas escolas.

Ressaltamos também que, enquanto estas condições próximas das ideais não são atingidas, há relatos de muitas escolas que tomaram iniciativas de constituírem bibliotecas, mesmo que precárias, conforme nos conta Campos e Bezerra (1998). Maroto (2009) também aponta uma série de iniciativas de sucesso implementadas em bibliotecas escolares de vários estados, que incluem: aulas de literatura realizadas em vários locais da escola, para despertar a atenção dos alunos; realocação da biblioteca para uma sala mais adequada na escola e a sua reforma, realizada com a ajuda de toda a comunidade escolar; realização de diversas 
atividades, como a confecção de um jornal, pintura, desenhos, rodas de leitura, palestras, oficinas, práticas de escrita, que incluem sua publicação, exposições de trabalhos realizados pelos alunos, dentre outras; feiras literárias, encontros com escritores; exibição de vídeos, jogos, teatro, sessões de leitura realizadas pelos alunos em domicílios ou instituições sociais, aproximando-os da comunidade, etc.; participação dos alunos na organização do acervo e estratégias para sua divulgação e dinamização; parcerias com órgãos públicos e privados e também a comunidade escolar e os familiares dos estudantes.

A partir de tais relatos, vemos a importância de que, apesar das dificuldades que afetam a atuação das bibliotecas, das quais já falamos na seção anterior, circulem sentidos mais coloridos, otimistas, em relação a essa instituição, uma concepção mais ampla que, ao invés de condená-la ao esquecimento ou negar o descaso e os problemas existentes (inserindoa num mundo de maravilhas tecnológicas ainda muito distante), tente superá-los, suscitando ações em prol dessa instituição, ainda que estas não correspondam às condições mais propícias. Observamos, também, que a já falada importância de que outros atores da comunidade participem da biblioteca é fundamental para que seja escrita uma outra história, que tire as bibliotecas do isolamento e estagnação que as rondam desde o início de sua atuação no Brasil Colônia. Ao falarmos com entusiasmo dessas iniciativas, nem sempre tão bem sucedidas, de revitalização de bibliotecas escolares, não estamos considerando menos importante ou desnecessário o amparo político, pois o papel de criar e estruturar bibliotecas nas escolas públicas brasileiras é (ou deveria) ser assumido pelos governos. Entretanto, diante do marasmo e descaso que estes demonstraram até o presente, mesmo em suas ações pontuais (divulgadas como grandes feitos em prol das bibliotecas, como a distribuição de acervos para escolas que não tem as mínimas condições de alocá-los e dinamizá-los), surgem lampejos de vida em bibliotecas escolares, os quais nos levam a pensar que é possível enfrentarmos as dificuldades e constituirmos bibliotecas escolares mais dinâmicas, desejáveis e abertas ao múltiplo, com mais cores, sons e movimento a delinearem uma outra forma de discursivizálas nas redes da Internet.

No contexto de uma sociedade marcada pelos novos meios de comunicação e informação, dos quais já falamos no capítulo anterior que destaca a Internet, surgem - a partir das considerações acerca das dificuldades vividas pelas bibliotecas e do desejo de superar essa visão "tradicional", tida como restritiva - iniciativas que visam a uma dinamização desta instituição e a outras formas de concebê-la e se relacionar com os recursos voltados para a educação e a cultura, como, por exemplo, a chamada biblioteca escolar digital, da qual falaremos a seguir. 


\title{
4.3 Apontamentos sobre a biblioteca escolar digital: um discurso ainda em construção
}

\author{
Quando se proclamou que a Biblioteca abarcava \\ todos os livros, a primeira impressão foi de \\ extravagante felicidade. (BORGES, 2001, p. 96)
}

No percurso traçado até aqui, abordamos uma série de questões sobre a Internet, desde a sua estrutura e desigualdade de acesso, até os movimentos do sujeito que circula em suas redes, a supervalorização que lhe é conferida e a promessa de proporcionar a emergência de outros discursos enunciados por sujeitos aos quais, muitas vezes, é negada a palavra. Discorremos também sobre a biblioteca escolar e os sentidos que lhe atribuem um papel imprescindível à educação, além de outros, mais negativos, pelos quais são enunciadas as diversas dificuldades sofridas e também uma concepção restrita que a discursiviza como um local de guarda de livros, um apêndice da escola, silenciando os efeitos de prazer por estar seu âmbito e os diversos materiais, suportes e atividades que pode oferecer. A partir desse embasamento teórico, questionamo-nos se/como é possível que a biblioteca escolar se estruture também nas redes da Internet, estabeleça-se nelas, através da criação de uma biblioteca escolar digital.

Não se trata absolutamente de traçarmos uma dicotomia entre uma biblioteca escolar, física e amiúde desgastada, e sua "versão" digital, emblema do moderno e desejável em uma "sociedade de informação"; não cremos que uma é melhor do que a outra, devendo substituíla, mas que elas podem conviver simultaneamente, de modo a oferecerem uma série de recursos e suportes. Assim sendo, ao acervo da biblioteca e às atividades culturais e educativas realizadas em seu espaço, acrescenta-se o acesso a outros recursos, os quais, talvez, jamais poderiam fazer parte dela, visto que nenhuma biblioteca, seja física ou digital, pode abarcar tudo, como a infindável biblioteca imaginada por Borges (2001). Dentre esses recursos que podem ser utilizados de maneira a dinamizar as práticas educativas, temos diferentes tipos de obras digitalizadas ou produzidas já no formato digital, imagens diversas, fotografias, arquivos sonoros e de vídeo, jogos educativos, e muitos outros, além da possibilidade de estar em contato com diferentes discursos, sujeitos e redes de memória, tecendo uma outra relação com a linguagem, mais plural e incitante; lembrando que tais possibilidades dependem da forma como tais objetos discursivos são compreendidos, ou seja, não como textos fechados a serem decodificados, mas como: 
unidade no processo de significação, é a totalidade da qual se parte na análise da estruturação do discurso. [...] o texto não é a soma de frases e não é tampouco soma de interlocutores. $\mathrm{Na}$ constituição do texto entram elementos menos determinados, menos mensuráveis que segmentos lineares e número de interlocutores. Como o texto é um espaço, mas um espaço simbólico, não é fechado em si mesmo: tem relação com o contexto e com os outros textos. (ORLANDI, 2003a, p.159-160)

Disponibilizada na Intranet (rede local da escola), ou, de forma mais ampla, na Internet (o que possibilitaria aos alunos o acesso a partir de qualquer outro computador), uma biblioteca digital, organizada pela escola, em parceira com os próprios alunos, poderia significar um novo sopro de vida nesta instituição, despertar novos interesses e aumentar seu escopo de ação, valorizando tanto os materiais impressos e o dia-a-dia de uma biblioteca escolar bem cuidada e movimentada, quanto os novos recursos eletrônicos, que estejam em consonância com as atividades realizadas na sala de aula e biblioteca, indo mais além, levando o sujeito-aluno, que navega pela rede, a descobrir novos mares, ocupar outras posições. Consideramos que, a partir dessa imbricação, que envolve a atuação da biblioteca escolar edificada na escola e em uma rede de computadores, pode-se construir:

um processo de ruptura em relação às ações autoritárias do modelo pedagógico seguido ainda pela maioria das escolas brasileiras, promovendo um ambiente instigante, estimulante e receptivo. Assim, é necessário direcionar um novo olhar para a biblioteca escolar, pôr em circulação outros discursos, romper a interdição do prazer e dizer palavras que possam desestabilizar o marasmo e a apatia reinante em várias delas. (FERRAREZI; ROMÃO, 2008a, p. 144)

Sendo assim, apontamos que a criação de dinâmicas redes de conhecimento entre os sujeitos de diferentes comunidades escolares é um dos caminhos possíveis a serem seguidos, em prol dessa ruptura de discursos parafrásticos e ações desinteressantes, comumente encontrados nas escolas brasileiras. Posto isto, para Santos e Amaral (2006, p.76), a constituição da Biblioteca Escolar Digital (BED) será fundamental para a construção dessa rede de conhecimento digital, proporcionando: "a produção de conhecimento organizado e disseminado a toda uma comunidade, seja ela escolar ou além da escolar que desejam contribuir e participar desta inovação educacional brasileira". Nestas redes, os sujeitos não são considerados receptores passivos de conhecimento, mas são chamados a interagir, a construir sentidos, à medida que se familiarizam com as ferramentas disponibilizadas por essas novas maneiras de produzir e acessar os discursos; deste modo, conforme nos contam ainda Santos e Amaral (2006, p. 65), é possível: 
ensinar, de forma didática e pedagógica, os alunos das escolas a publicar e construir o acervo digital escolar, através de seus trabalhos apresentados em sala de sala, permitindo a transição do acervo da biblioteca tradicional para o acervo digital, enfocando a grande importância das mesmas para o ensino mediado pelo computador.

Assim sendo, além da variedade de obras (selecionadas para estarem lá) que o sujeitoleitor pode acessar integralmente na biblioteca digital, destacamos a oportunidade dele experimentar novas e diferentes formas de construir seu discurso, amarrando-o a vários outros que estão à deriva na rede eletrônica, com os quais tece relações de concordância e/ou confronto, fazendo falar o múltiplo. Apostando-se nessa pluralidade que pode constituir a biblioteca escolar digital, promove-se uma aproximação entre a Internet, vista como uma valiosa fonte de pesquisa, e a sala de aula, relação esta que vem se expandindo de forma crescente, segundo Amaral e Garbin (2008, p. 5-6):

Os ambientes virtuais educacionais têm se tornado cada vez mais populares no ciberespaço e em instituições de ensino, que passaram a utilizar tal ferramenta para a disponibilização de notas, exercícios, aulas virtuais, com auxilio de fóruns e bate-papos. Temos até mesmo casos em que um curso pode ser concluído por meio desses ambientes. É possível, então, percebermos a importância que esses ambientes têm adquirido atualmente.

Nesse espaço discursivo de circulação e construção de sentidos- produzidos por sujeitos que podem ocupar diferentes posições discursivas ao serem afetados pelas condições sócio-histórico-ideológicas-, as possíveis trocas de experiências e saberes entre os professores e alunos da mesma ou de diferentes unidades escolares são dotadas de grande importância, na medida em que tornam a escola um ambiente mais rico para o educando. (AMARAL; GARBIN, 2008).

Outras questões acerca da biblioteca escolar disponibilizada na Web são apontadas por González-Serna (2002), que considera importante que elas contenham, além de informações acerca de seu funcionamento, responsável, horário de atendimento etc., o catálogo completo de suas obras pertencentes ao acervo físico da biblioteca, visto que, assim, além do empréstimo ser facilitado, os professores podem preparar melhor suas aulas, utilizando os diferentes recursos encontrados na biblioteca. Também é destacada a possibilidade de inclusão de outros recursos não pertencentes à biblioteca física, tais como obras em formato digital e aquelas produzidas pelos próprios alunos:

Aparte de incluir en la 'web' de la biblioteca la posibilidad de consulta de los recursos físicos de los que disponemos y de la información sobre el funcionamiento de la misma, juzgamos que podría ser interesante ofrecer a los usuarios libros y documentos en formato electrónico; de esta manera 
podremos aprovechar las posibilidades que nos ofrece la red en cuanto a material digitalizado, pero también nos permitirá editar nuestros propios libros con textos escritos por los alumnos o profesores de nuestro centro y de esa manera motivar hacia la creación literaria o la investigación (GONZÁLEZ-SERNA, 2002, p. 5)

Entre os outros documentos aos quais se pode ter acesso, encontram-se os jornais e periódicos científicos de todo o mundo, disponibilizados gratuitamente (na íntegra ou parcialmente) na Internet, os quais constituiriam uma hemeroteca, por meio da qual seria possível "romper fronteras, de modo que abramos las puertas a otras culturas y lenguas" (GONZÁLEZ-SERNA, 2002, p. 6-7). Além dos textos completos, destaca-se a disponibilização do acesso a links de sites considerados interessantes e relevantes para a comunidade escolar, desde buscadores, como o mundialmente conhecido Google, até enciclopédias, dicionários e uma diversidade de páginas dedicadas às áreas curriculares, dentre outros temas que despertam o interesse dos sujeitos-leitores que alimentam e utilizam a biblioteca digital. Destacam-se, ainda, os recursos interativos que permitem ao sujeito produzir e fazer circular sentidos, entrar em contato com aqueles constituídos por outros sujeitos, o que é facilitado por meio de ferramentas, tais como o correio eletrônico, chat e o fórum de discussão, que podem estar disponíveis no ambiente da biblioteca escolar digital, permitindo que ela receba colaborações, "de todo tipo por parte de sus usuarios: textos -no exclusivamente linguísticos- creativos, breves reseñas de libros leídos o de sitios "web" visitados." (GONZÁLEZ-SERNA, 2002, p. 8).

Assim sendo, pudemos observar até aqui como a constituição das bibliotecas escolares no meio eletrônico pode significar muito mais do que a simples disponibilização do seu catálogo de obras, proporcionando novas maneiras de estar na linguagem, na medida em que são tecidos diferentes gestos de leitura e escrita neste novo ambiente, que se delineia como uma possibilidade de driblar as restritivas práticas educativas focadas no livro didático, historicamente praticadas em grande parte das escolas brasileiras. Entretanto, cabe ressaltarmos que, para que isso ocorra, são necessárias condições de acesso às novas tecnologias de informação e comunicação, as quais não estão distribuídas socialmente de forma equitativa. Sendo assim, marcamos que tais recursos informáticos, de computadores ao acesso à Internet, apesar da crescente expansão, ainda não estão presentes em todas as escolas do país, visto que, no ensino fundamental, 66,4\% dos alunos tem acesso a computadores, 72,5\% deles contam com Internet e apenas 57,7\% com Internet banda larga. No ensino médio, os índices são um pouco maiores: 91,9\%, 92,4\% e 75,4\%, respectivamente. (BRASIL, 2009). Comparando estes dados aos já apresentados anteriormente sobre as bibliotecas escolares, 
observamos que há mais alunos com acesso a computadores e Internet do que a bibliotecas, o que demonstra o descaso com que esta instituição é tratada na escola e a valorização que é conferida às tecnologias de informação e comunicação. Para citarmos apenas alguns exemplos, ao longo do desenvolvimento desta pesquisa, nós visitamos, de forma nãosistemática, sites de escolas públicas e particulares de vários estados brasileiros; nestes sites, especialmente os de escolas particulares, percebemos, grosso modo, como as salas de informática e também as atividades esportivo-culturais ganham destaque, através de textos e imagens, como se representassem uma "boa propaganda" para a escola, o que muitas vezes não ocorre com a biblioteca, posto que frequentemente não é mencionada sequer sua existência física, muito menos on-line. Isso nos leva a pensar nos jogos de formações imaginárias proposto por Pêcheux (1997), na imagem que se faz dos sujeitos-navegadores que visitarão a página eletrônica de uma escola, a fim de investigarem sua qualidade, seu projeto educativo: será que estes não considerariam importante a biblioteca escolar estar inclusa nele? Assim sendo, a partir do que está exposto na home page do Colégio Base $\mathrm{B}^{3}$ (da rede particular de ensino, em Goiânia- GO), que será mostrada a seguir, e do que observamos também em várias outras páginas eletrônicas, inferimos que o sujeito-gestor escolar imaginariza que o pai/aluno (consumidor de sua escola) valoriza a leitura e o ensino, enquanto atribui a si mesmo uma imagem de prestígio e diferencial, pela qual ele estaria apto a corresponder aos anseios de seus consumidores; em contrapartida, esse sujeito-gestor projeta uma imagem da biblioteca escolar como sendo desprezível, não valorizável. A partir destes jogos imaginários e da antecipação de tais sentidos, observamos que, enquanto que o sujeito-gestor destaca e anuncia, no site de sua escola, a existência de instalações como sala de estudos e salas de aula climatizadas, a biblioteca escolar não é discursivizada, exaltando-se apenas, pelo discurso publicitário, uma série de outros recursos oferecidos, que incluem uma sala multimídia e até um academia de ginástica, confirmando, assim, a imagem desprestigiada que se faz da biblioteca escolar.

\footnotetext{
${ }^{3}$ Disponível em: <http://www.colegiobase.com.br/colegio.php>. Acesso em: 18 dez. 2009.
} 


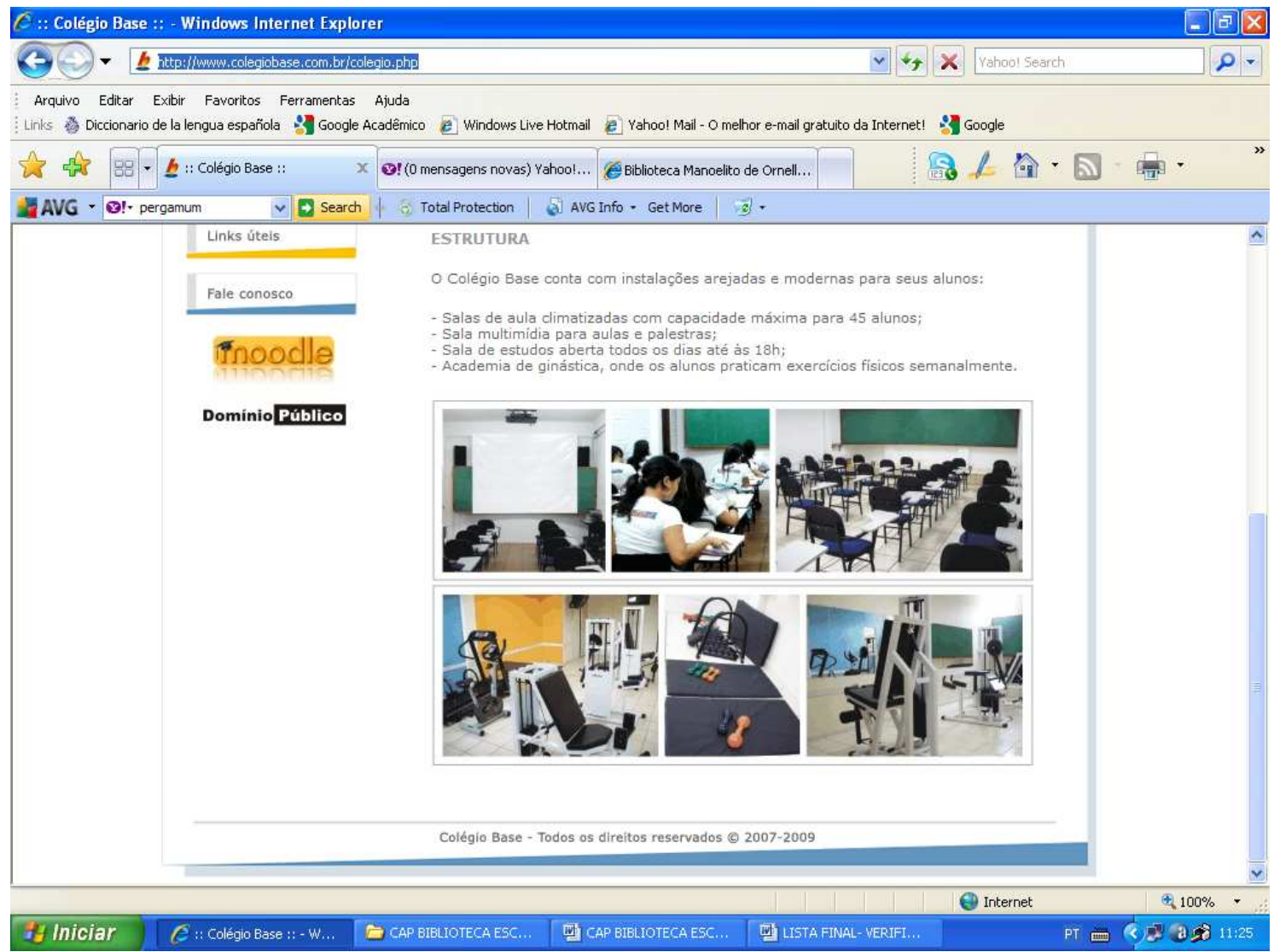

De maneira semelhante, no Centro Cultural do Centro Educacional da Lagoa ${ }^{4}$ (Rio de Janeiro), a biblioteca também não consta em seu quadro de atividades, que abrange diversas outras, desde esportivas até musicais:

\footnotetext{
${ }^{4}$ Disponível em: <http://www.grupocel.com.br/celweb/Modelo.aspx>. Acesso em: 15 dez. 2009.
} 


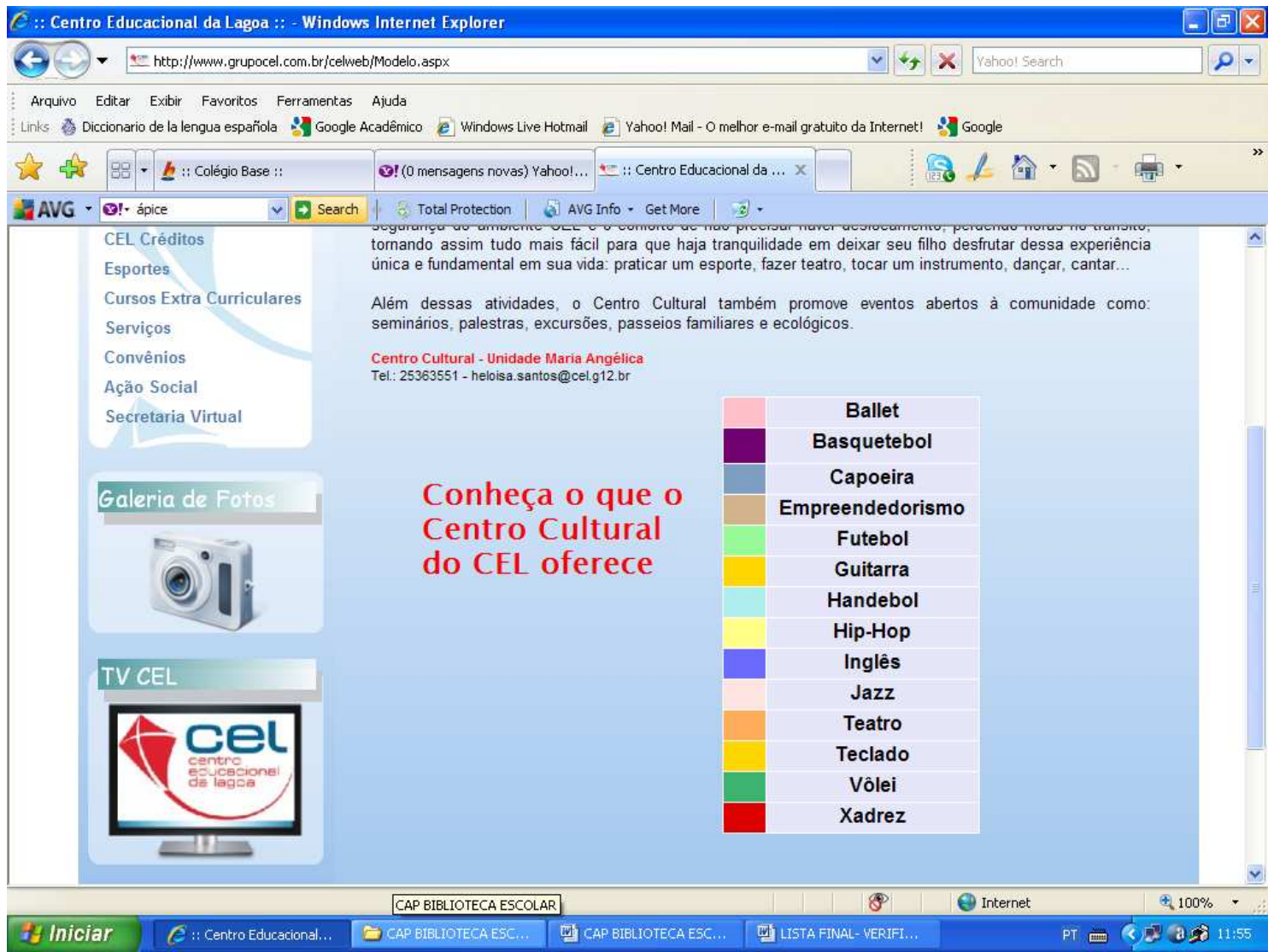

Por conseguinte, temos que nem sempre as condições financeiras são determinantes para a existência, bom funcionamento e valorização de bibliotecas, havendo uma série de outras questões sócio-político-ideológicas que afetam os sentidos construídos acerca delas, sejam de valorização ou de descaso. Em vários sites visitados, a biblioteca está ausente, assim como quaisquer outros recursos além das salas de aula, mas, em outros, como os dois que mostramos anteriormente, ela não figura entre diversos recursos disponíveis, não fazendo parte do projeto educacional da escola, do que se imaginariza como importante e digno de destaque, seja no âmbito da escola ou de seu site.

Em várias outras páginas eletrônicas visitadas, é mencionada apenas a existência de biblioteca, muitas vezes presente somente em uma foto, misturada às outras dependências da escola, ou em uma descrição breve sobre a estrutura escolar, sem mais informações a respeito de sua constituição, atuação, ou quaisquer outras; como podemos ver nos sites do Colégio Americano Batista ${ }^{5}$ (em Recife- PE) e da Escola Estadual de Ensino Fundamental e Médio John Kennedy ${ }^{6}$ (Porto Velho- Rondônia), respectivamente mostrados a seguir.

\footnotetext{
${ }^{5}$ Disponível em: <http://www.americanobatista.com.br/conteudo/?id=153>. Acesso em: 15 dez 2009.

${ }^{6}$ Disponível em: <http://www.escolajohnkennedy.com.br/>. Acesso em: $15 \mathrm{dez} 2009$.
} 


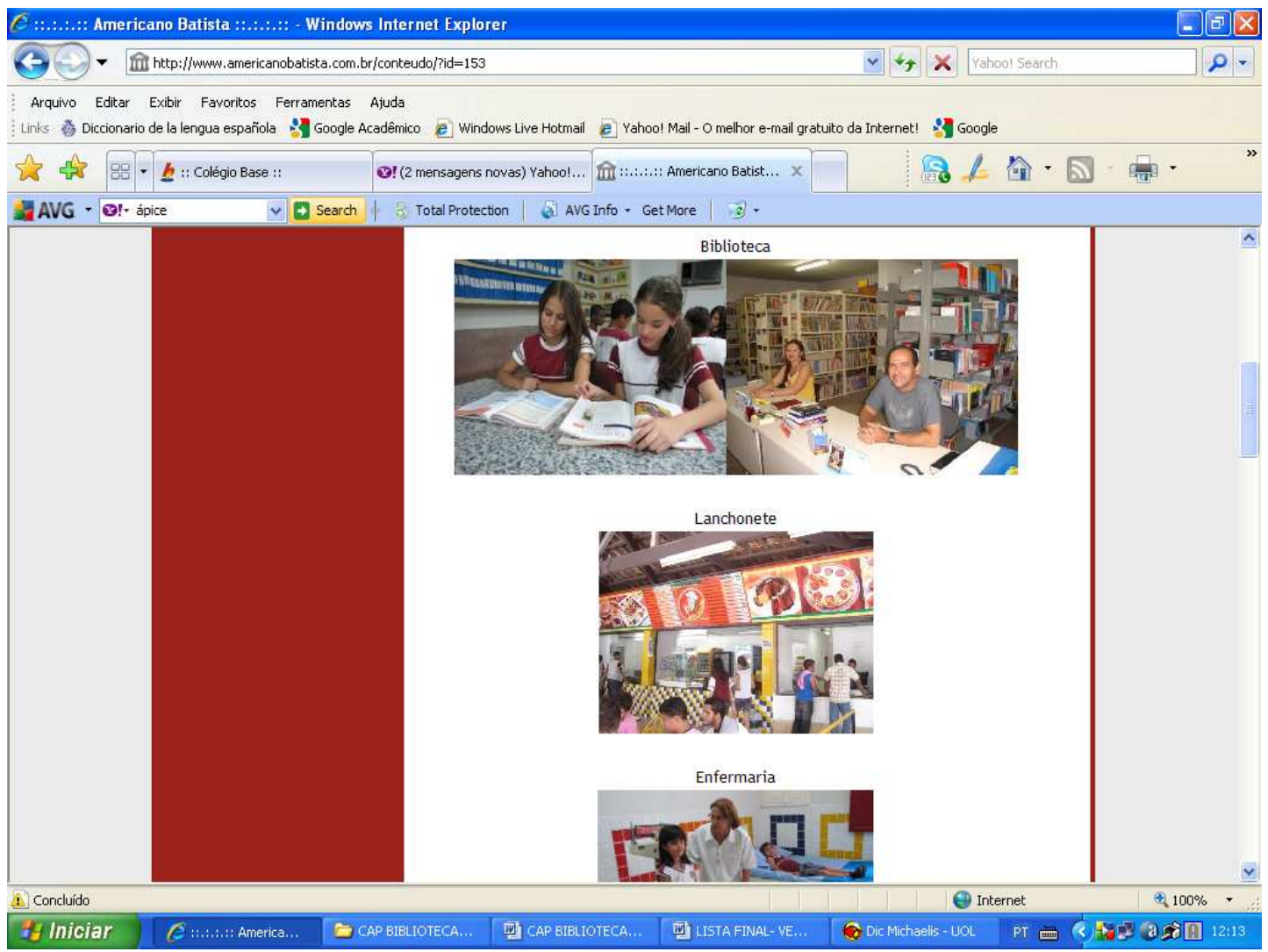

\section{Escola John Kennedy - Construindo futuros cidadăos. - Windows Internet Explorer}

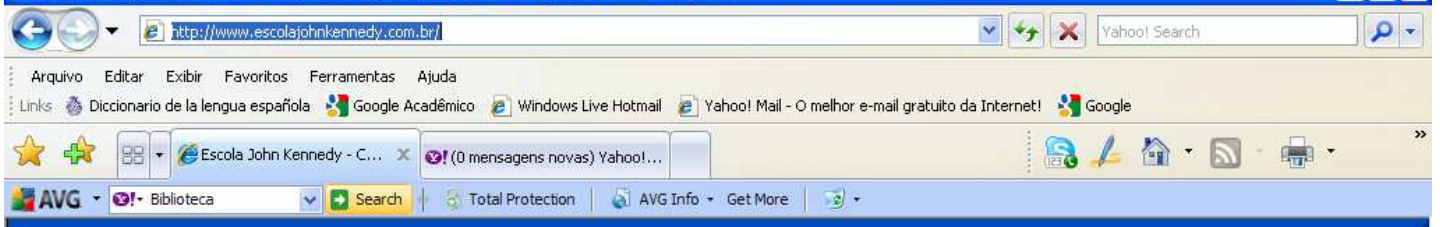

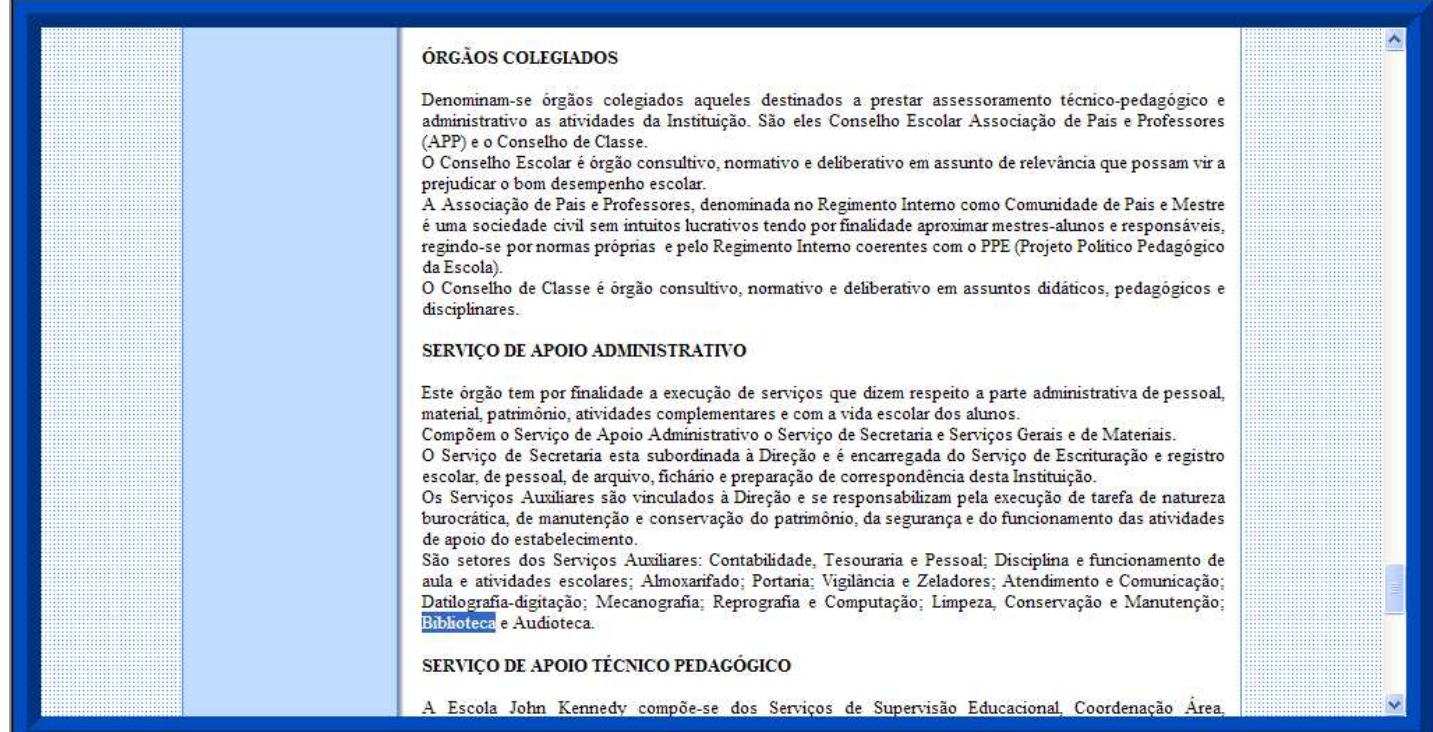


Acerca do primeiro site apresentado, destacamos que, ainda que não haja nenhuma menção ou maior destaque à biblioteca, além das duas fotos expostas, nelas é possível observarmos a presença de um acervo e de um ambiente de estudo, no qual são possíveis os gestos de leitura de sujeitos-crianças, além da existência de profissionais, em seus postos de trabalho, à espera de alunos que solicitem ajuda e atendimento, o que indiciam a disponibilidade de uma biblioteca aberta, acessível. Todavia, no último site apresentado, observamos sentidos mais restritos, suscitados pela inclusão da biblioteca em meio a outros órgãos de "serviço de apoio administrativo". Apresentada desta maneira, como um "setor dos serviços auxiliares" que se responsabilizam pelas atividades burocráticas, mecânicas, de manutenção e vigilância, a biblioteca e a audioteca figuram ao lado da "tesouraria", "contabilidade", "disciplina e funcionamento de aula", "vigilância e zeladores", "datilografia", "almoxarifado", "conservação e manutenção", "mecanografia”, "reprografia", etc.; sendo assim, são evocados os sentidos que imaginarizam a biblioteca como um apêndice da escola, indiciando o possível lugar que lhe cabe ocupar nela, à medida que silencia outros possíveis, acerca de seu fundamental papel como centro ativo de aprendizagem, que lhe é frequentemente atribuído em documentos político-científicos, como já mostramos na seção anterior.

Destacamos também que, em alguns sites visitados, circularam outros sentidos de restrição sobre a biblioteca da escola, apresentando apenas as suas normas de uso, o que é proibido fazer em seu ambiente, silenciando tudo aquilo que é possível, interditando a emergência do prazer de circular por este espaço. No site do Colégio Boa Viagem ${ }^{7}$, localizado em Recife (PE), além das informações sobre a organização do acervo e a estrutura da biblioteca, chamou nossa atenção as penalidades, obrigações, advertências, normas e regras enunciadas, marcadas pelo emprego parafrástico dos sentidos de ameaça ao sujeito-aluno, de negação, proibição e penalização, através do uso do advérbio "não", e de uma série de termos correlatos, como "multa", "débito", "perda", "dano", "perturbar a ordem", "silêncio", "advertido", "reincidência", "proibido", "suspensa", "impossibilitado", que funcionam como marcas linguísticas que colocam o sujeito-aluno na posição de infrator, daquele que precisa da lei para coibi-lo. Tais infrações são topicalizadas, na lista de "normas gerais", em quatro instâncias, que implicam a gradação de suas infrações, as quais, em último grau, podem acarretar a tomada de "medidas legais possíveis". Diante deste receituário punitivo, questionamos: quem irá se arriscar diante de um aparato repressor tão eficaz? Que aluno

\footnotetext{
${ }^{7}$ Disponível em:<http://www.cbvweb.com.br/index.php?arquivo=exibe_chamada\&olhar=2〉. Acesso em: 10 dez. 2009.
} 
poderá ocupar a posição de sujeito-leitor diante da imagem de infrator que já lhe é dada a priori?

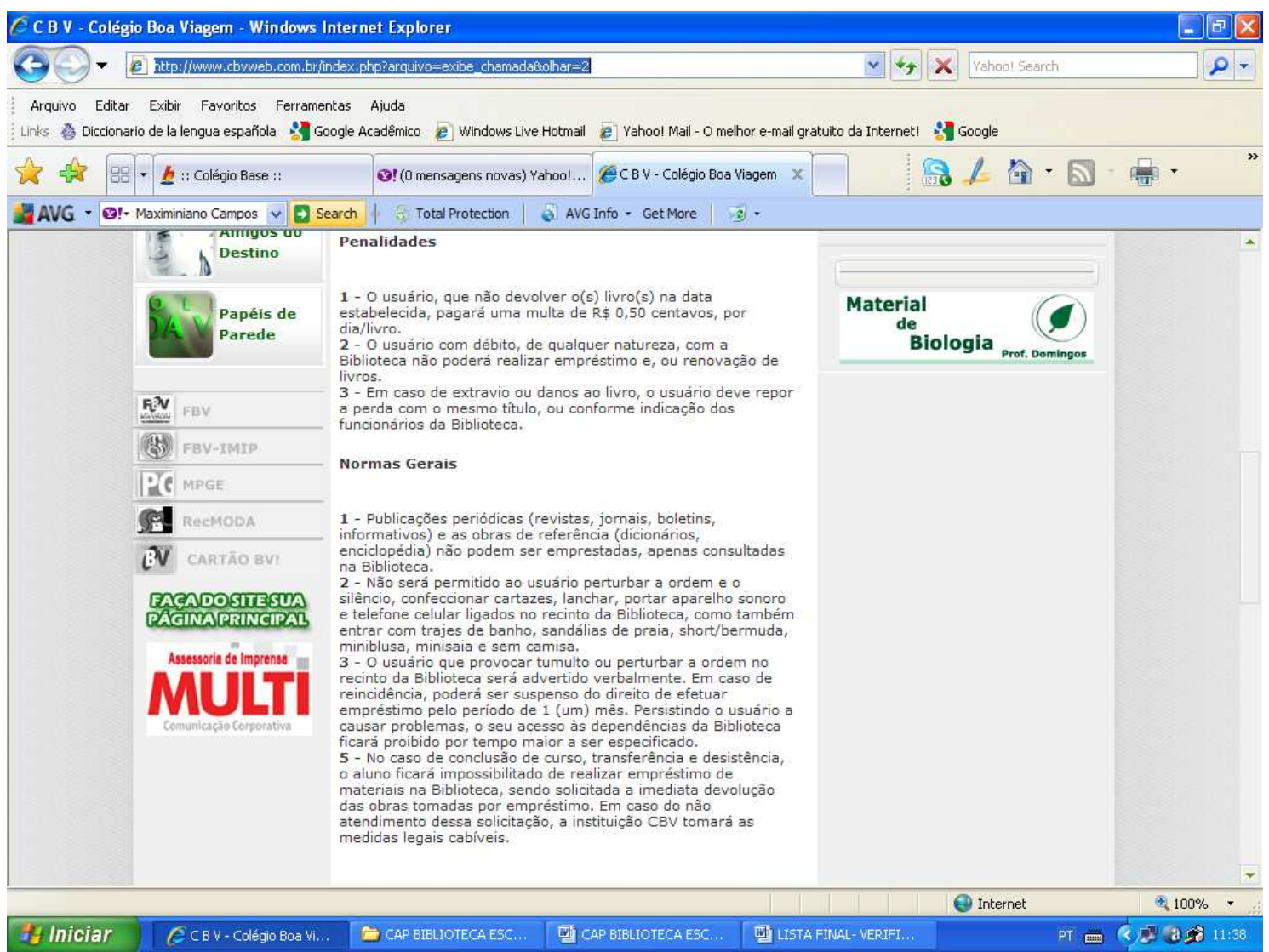

Estes sentidos de restrição atribuídos à biblioteca são reforçados pela norma que restringe a aproximação entre o leitor e as obras, ao estabelecer que "o usuário não tem acesso direto às estantes". Diante desse impedimento, parece-nos que as informações acerca da organização do acervo não estão a serviço do leitor, sendo apenas mais um mecanismo de censura, revelando uma situação recorrente em muitas escolas e que consideramos ser bastante nociva para a emergência do deleite de estar numa biblioteca, entre os livros e demais materiais aos quais se pode ter acesso nela. 


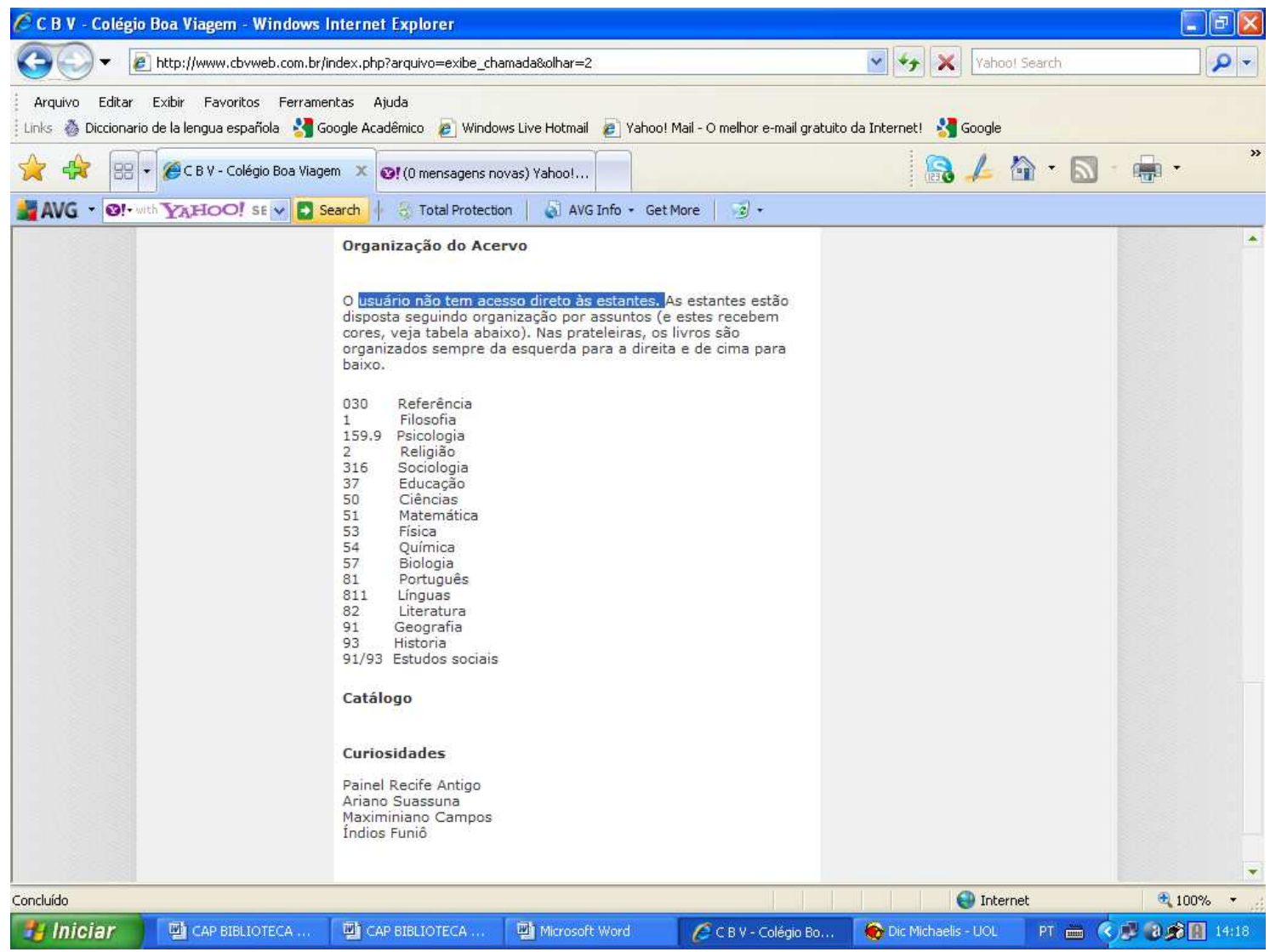

Consideramos que tais práticas confirmam os sentidos negativos associados à biblioteca, relacionando-a a um lugar distante, rígido, pouco acessível, em que não se quer estar. Observamos também que, entre os sites visitados, poucos, como o da Escola Municipal Américo Silva ${ }^{8}$, (situada no Rio de Janeiro), discursivizam de forma mais ampla a sua biblioteca, concedendo-lhe um link exclusivo; nele, destacam-se os recursos e serviços disponíveis, a realização de projetos e a construção de um catálogo a ser disponibilizado na Internet, a partir do processo, em curso, de informatização da biblioteca, conforme podemos ver a seguir:

\footnotetext{
${ }^{8}$ Disponível em: <http://www.emas.org.br/site/index.php?id=11>. Acesso em: 18 dez. 2009.
} 


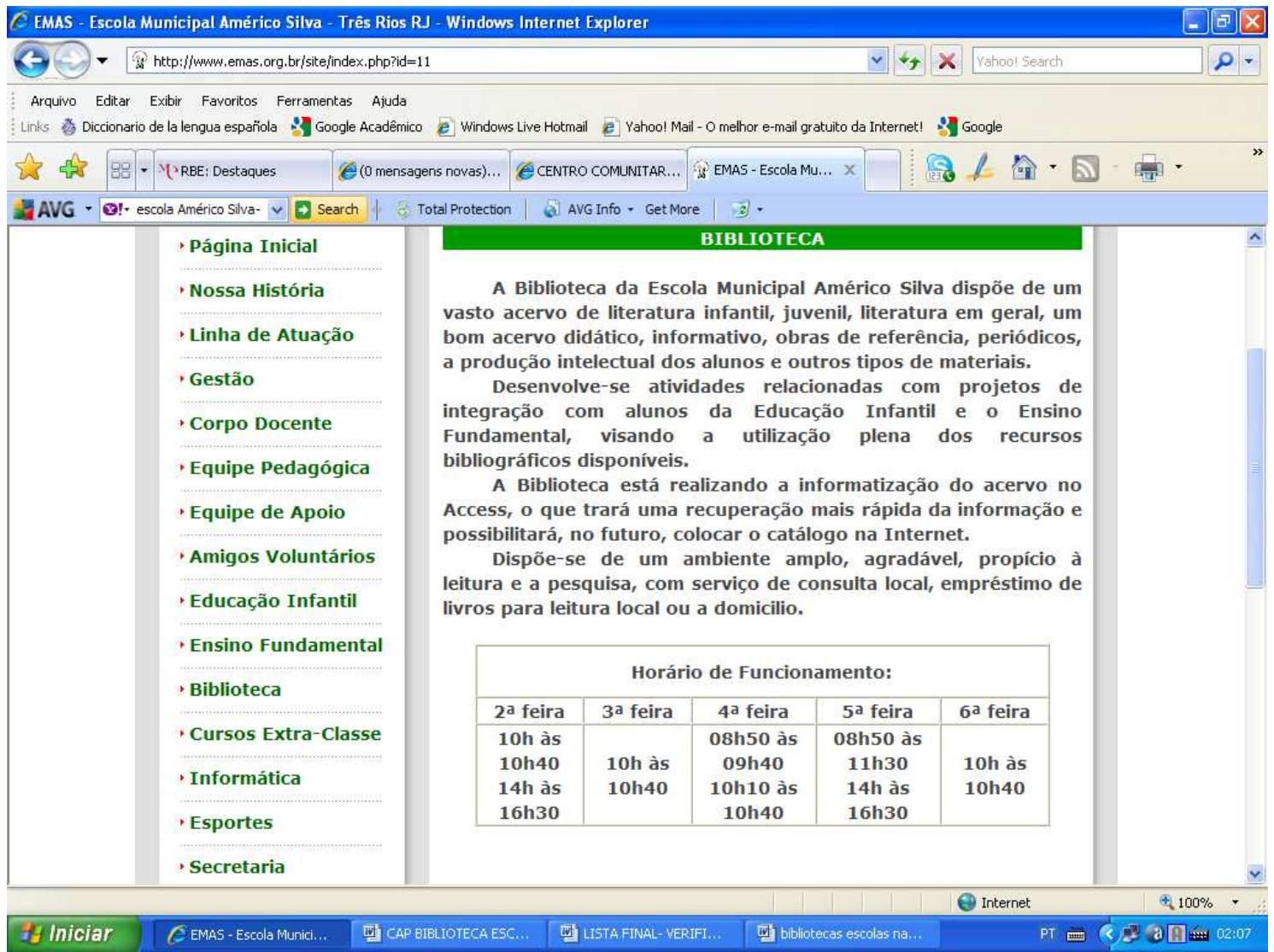

Temos, assim, outra formação discursiva, que regula o que pode e deve ser dito sobre a biblioteca escolar, da qual fazem parte outros sentidos que não os de restrição, conferindolhe maior valorização e vivacidade, ao preverem a "utilização plena dos recursos bibliográficos disponíveis", e não sua simples guarda. Consideramos importante destacar também, dentre os sites em que foi dado um enfoque especial à biblioteca, o da Escola Estadual Modelo 9 (em Araguaína, Tocantins) muito chamou nossa atenção, pois apresenta sua "Biblioteca dinâmica" por meio de várias imagens coloridas de atividades nela realizadas, movimento de sujeitos, livros, fantasias e gestos de leitura e escrita que inscrevem sentidos de uma biblioteca escolar mais próxima da concepção considerada "ideal". Isso podemos ver a seguir:

\footnotetext{
${ }^{9}$ Disponível em: <http://www.escolamodelo.com.br/bibliotecadinamica.htm>. Acesso em: 11 dez. 2009.
} 

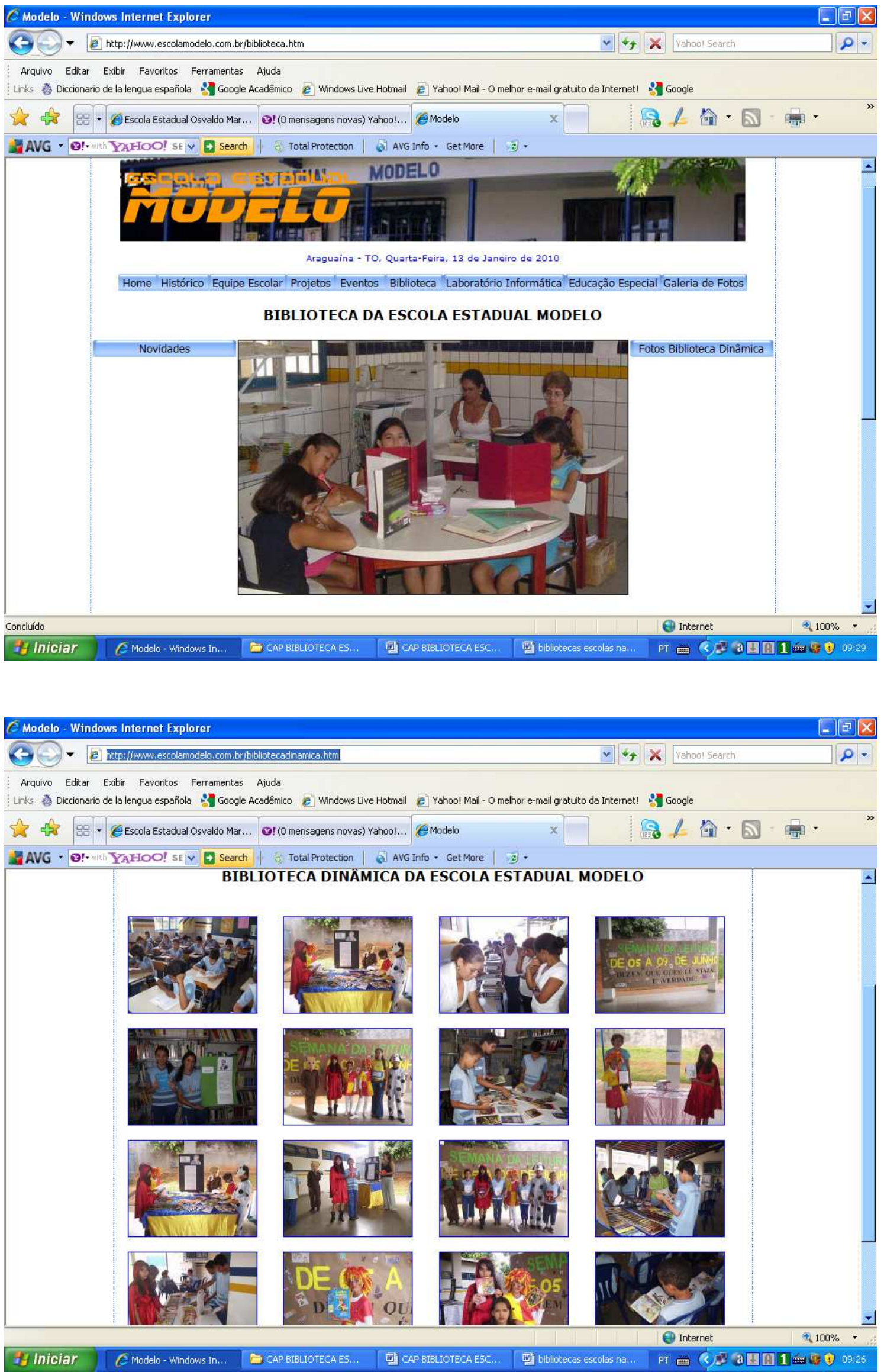


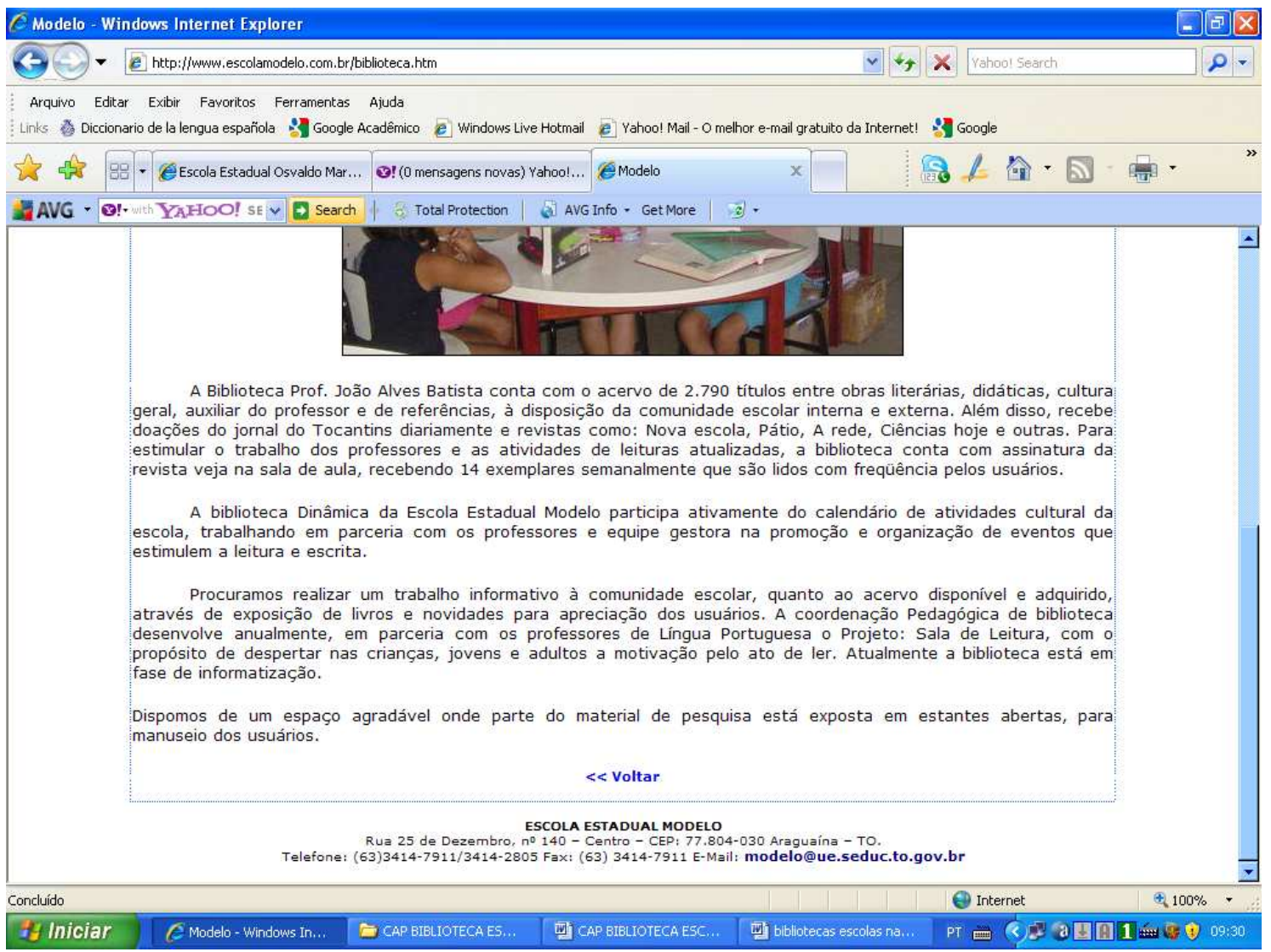

Flagramos também sentidos sobre o acervo, profissionais envolvidos (professores), parceiros da comunidade, integração à escola e atividades realizadas que significam outras maneiras de enunciar sobre uma biblioteca escolar da rede pública de ensino, ressaltando, também, seu ambiente agradável e a informatização do seu acervo. Estes sentidos mais plurais também foram encontrados na página eletrônica de algumas outras escolas, como a Escola Estadual Francisco Cristiano Lima de Freitas ${ }^{10}$, em São Bernardo do Campo (SP). Através do link "biblioteca", podem ser acessados os livros mais procurados, lista dos voluntários que atuam na biblioteca, horário de atendimento e outras informações, além de fotos em que alunos lêem pelos corredores, cujas legendas sinalizam a importância dada à leitura, apesar das dificuldades enfrentadas, como se observa nas marcas: "ler é preciso", "esse é o futuro" e "cultura com pouco espaço". A biblioteca, frequentemente tão carente de sujeitos e sentidos menos parafrásticos, é aqui representada, através das fotografias, como um espaço preenchido e disputado, repleto de sons, cores e movimentos:

\footnotetext{
${ }^{10}$ Disponível em: <http://www.escolafranciscocristiano.hpg.ig.com.br/index_int_4.html>. Acesso em: 9 dez. 2009.
} 

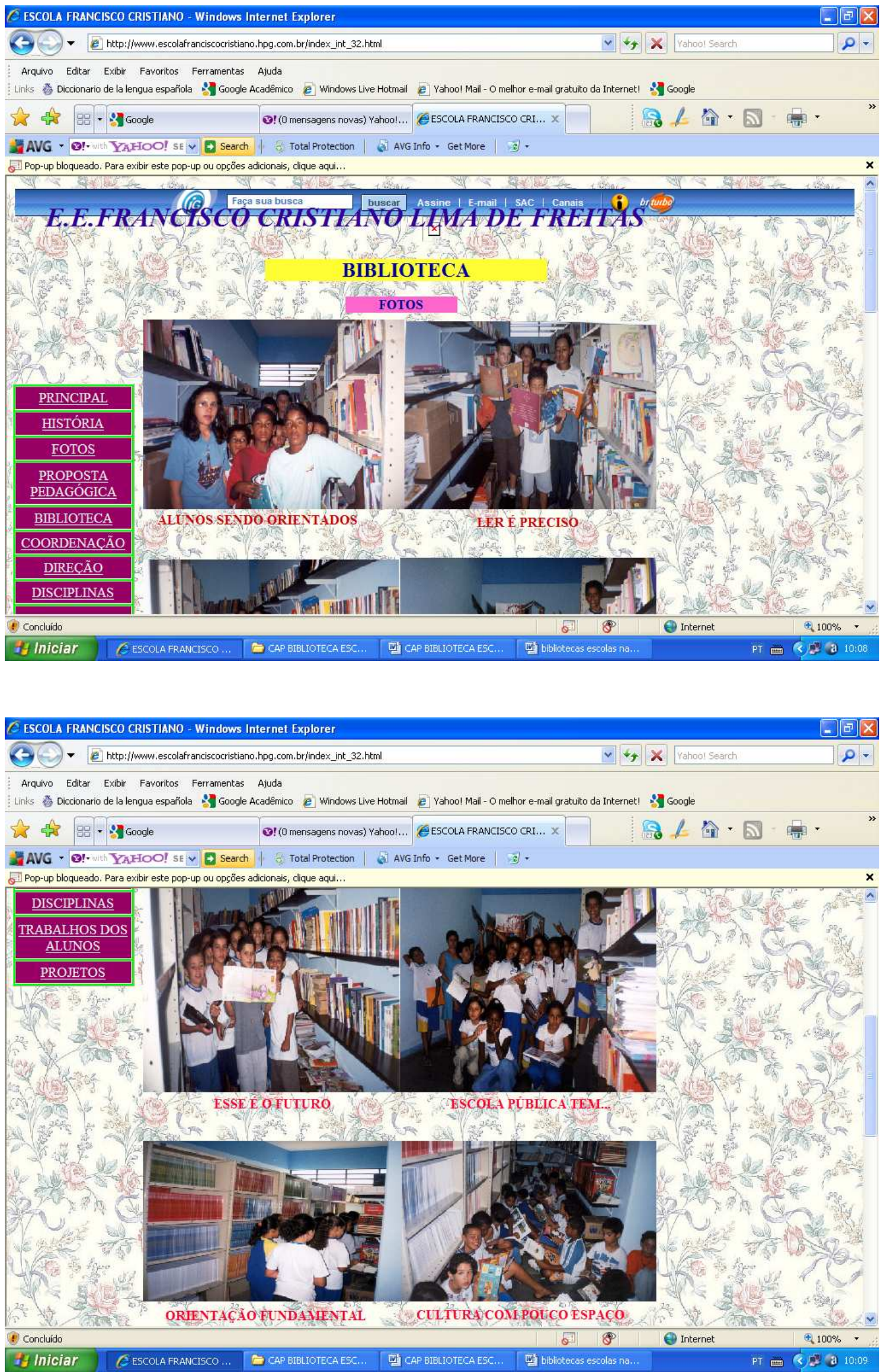
Em alguns outros sites de escolas das redes pública e particular de ensino, encontramos um espaço dedicado ao catálogo das obras disponíveis na biblioteca, o que demonstra que o conhecimento acerca desta instituição e seus recursos é importante, devendo figurar entre outras informações sobre a escola; tal catálogo pode ser disponibilizado de maneira mais simples, como a listagem encontrada na página da Escola Estadual Genaro Domarco $^{11}$ (em Mirassol- SP), ou mais elaborada, como consta na do Colégio Bom Jesus ${ }^{12}$, de ensino particular e presente em várias cidades brasileiras, em cujo site há um sistema de gerenciamento das bibliotecas no qual é possível, além de consultar as obras disponíveis no acervo de todas as unidades do colégio, fazer reservas e deixar sugestões, ler, dizer e ser lido, conforme mostrado, respectivamente, a seguir:

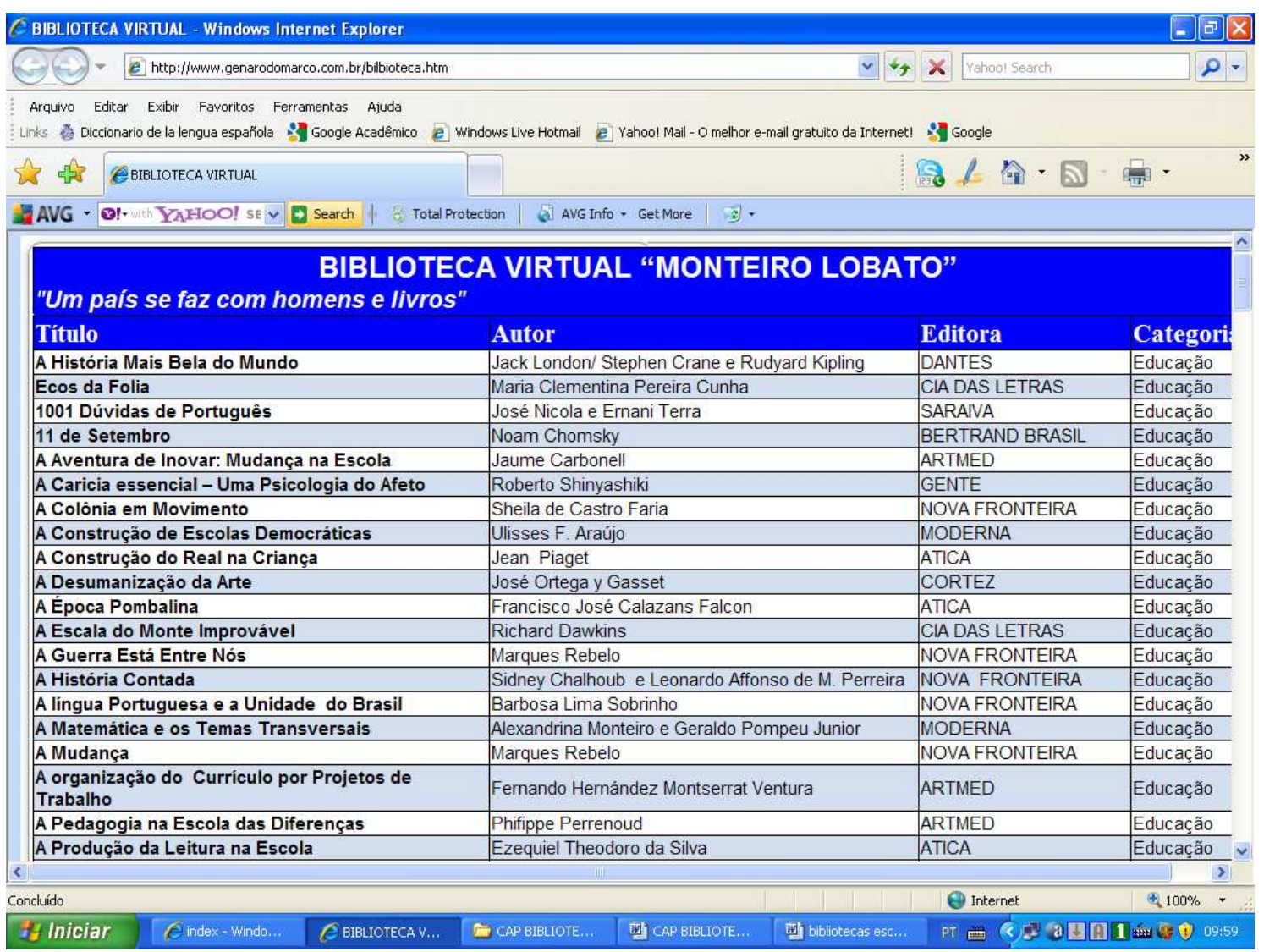

\footnotetext{
${ }^{11}$ Disponível em: <http://www.genarodomarco.com.br/bilbioteca.htm>. Acesso em: 28 nov. 2009.

12 Disponível em: <http://pergamum.bomjesus.br/pergamum/biblioteca/index.php>. Acesso em: 15 dez. 2009.
} 


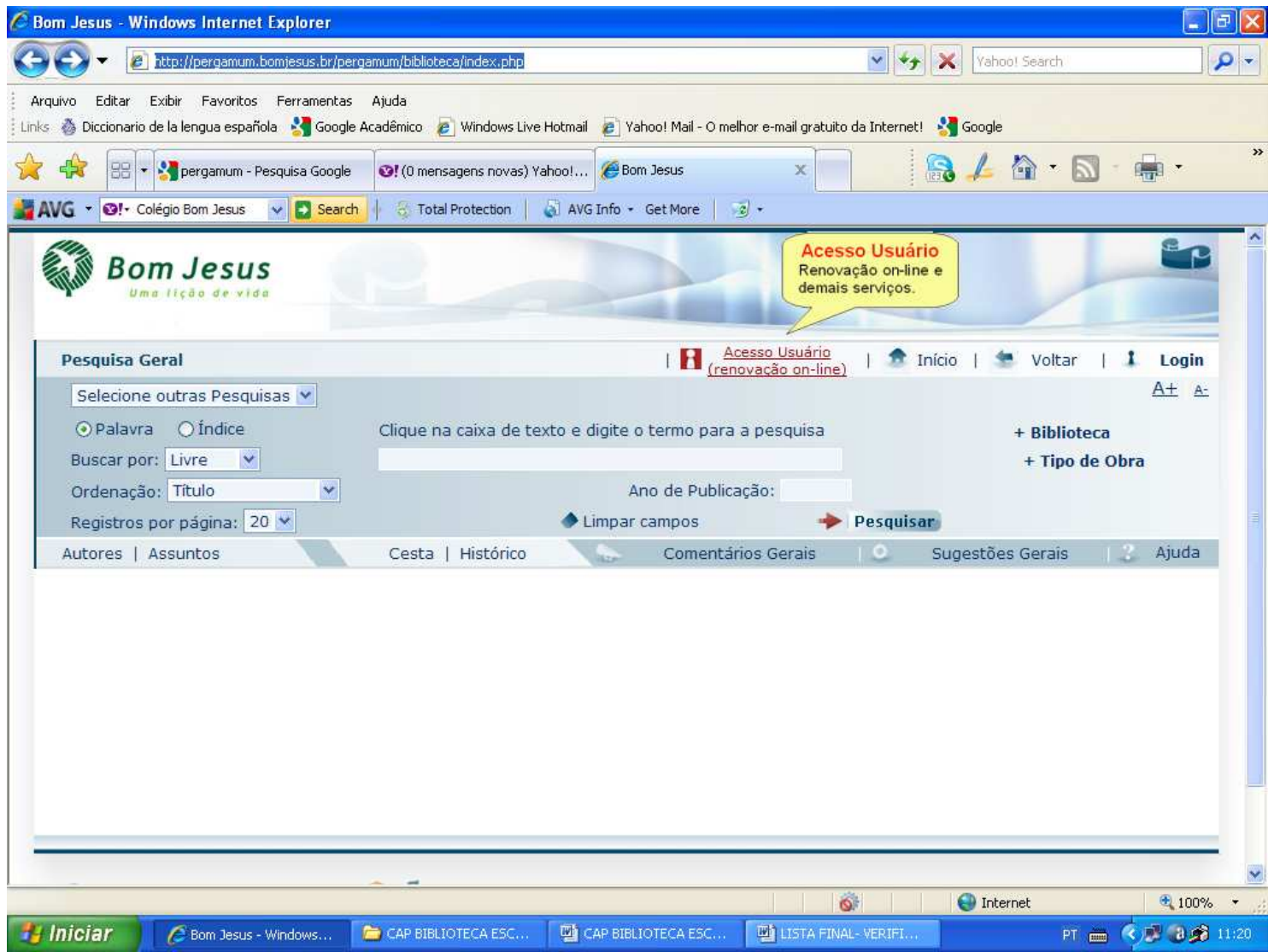

Sendo assim, o termo "acesso" funciona discursivamente de maneira diferente nesta página eletrônica, não aparece acompanhado de um advérbio de negação, não é proibido o acesso ao acervo, mas sim garantido, ainda que virtualmente. Observamos também que, em muitas outras escolas, que dedicam em seus sites um espaço maior à biblioteca, menciona-se a presença de computadores e são disponibilizados os bancos de dados de seus acervos, além de outras informações técnicas e estruturais a respeito da mesma; porém, nada mais além disso, nenhuma interação, fotos ou relatos de atividades que dinamizem tais recursos disponíveis, delineando, assim, apesar da presença da tecnologia, sentidos tidos como tradicionais, ressaltando os seus aspectos físicos e materiais, significando uma instituição sem vida, nem movimento.

Vale destacar, ainda, que não faz parte dos nossos objetivos investigar a fundo a representação da biblioteca em sites de escolas brasileiras, nem apresentar conclusões definitivas ou um panorama sistematizado acerca do tema; contudo, consideramos interessante apresentarmos, de maneira geral, algumas impressões que nos suscitaram os movimentos de navegação por tais páginas eletrônicas e que nos permitiram observar, apesar do imenso descaso em relação à biblioteca escolar, algumas iniciativas interessantes de sua atuação na escola e nas redes da Internet, instalando outros sentidos para esta instituição, que 
rompem com o silêncio ao qual é comumente submetida e indiciam a pluralidade da $W e b$, que possibilita a emergência de diferentes sujeitos e discursos. Assim sendo, diante de tantas dificuldades e restrições que afetam a existência e constituição de bibliotecas físicas, a biblioteca escolar digital nos parece estar ainda muito distante, ao menos para grande parte das escolas particulares e, principalmente, públicas, o que instala um furo na formação discursiva que naturaliza os sentidos de que tudo e todos podem estar na rede. Entretanto, ocupar este (ciber)espaço discursivo não é impossível, pois acreditamos que, com o envolvimento de universidades, organizações não-governamentais e o Estado podem sair do plano teórico projetos que visem a ampliar as possibilidades de acesso e construção do conhecimento, disponibilizando aos sujeitos-alunos o contato com diferentes suportes e gêneros discursivos, novas formas de aprenderem e produzirem sentido, que vão além do livro didático e da sala de aula. A partir disso, poderia ser construída outra relação com a biblioteca escolar, delineada uma outra forma de concebê-la, inserindo-a na pauta de discussões da escola e tornando-a objeto de um trabalho comunitário, visto que os próprios alunos poderiam contribuir para a construção e manutenção de uma biblioteca escolar nas redes da Internet, atuando em conjunto com as ações empreendidas no âmbito da biblioteca física.

O exemplo narrado por Amaral e Garbin (2008), de uma iniciativa gestada no âmbito da Faculdade de Educação da Universidade Estadual de Campinas (UNICAMP) nos mostra como essa rede de relações, envolvendo a escola e diversos setores sociais, é possível e pode dar frutos. Por meio do projeto citado, foi construído um kit (testado em escolas da região de Campinas e, posteriormente, finalizado) para a constituição de um ambiente interativo, a "Biblioteca Escolar Digital”, contendo, além do próprio ambiente, o manual de instalação e utilização e os softwares necessários para tanto; acredita-se que este ambiente pode ser expandido para outras escolas, criando-se, assim, uma rede de conhecimento digital, a fim de otimizar o processo de ensino e aprendizagem.

Lembramos que essas iniciativas de inserção da biblioteca escolar na rede não podem ser vistas como isoladas, mas intrinsecamente relacionadas à dinamização e melhoria de suas instalações, recursos humanos, materiais e, principalmente, atividades que a levem a ocupar um lugar de destaque na escola e sociedade, estar próxima de seus leitores seja nas dependências da escola ou nas redes da Internet; assim sendo, a versão digital da biblioteca da escola não é melhor que ela e nem pode substituí-la, ao contrário, elas devem atuar juntas, complementando-se e enriquecendo as experiências proporcionadas aos sujeitos. Como já foi dito, estamos ainda no início deste caminho que se mostra promissor, se significar uma relação mais polissêmica com a linguagem, superando práticas educativas autoritárias. 
Contudo, em meio às simples menções de existência de acervos digitalizados, encontramos algumas bibliotecas escolares digitais, tais como apresentamos no início dessa seção, constituídas por uma série de recursos de interação entre sujeitos e discursos materializados no suporte digital. Apesar da ausência de outros recursos (como fóruns de discussão, chat, arquivos digitais de trabalhos escolares e integração com outras escolas) com a qual nos deparamos, podemos citar um exemplo de uma rede particular de escolas situadas em Belo Horizonte (MG), o Colégio Santa Maria ${ }^{13}$, que contém, em seu site, uma biblioteca digital, com alguns recursos interessantes, como diversas obras de literatura, periódicos, mapas e recursos audiovisuais disponíveis na íntegra, possibilidade de indicação de leituras, além de um catálogo do acervo disponível nas bibliotecas das unidades do colégio, como encontramos também nos sites de algumas outras escolas.

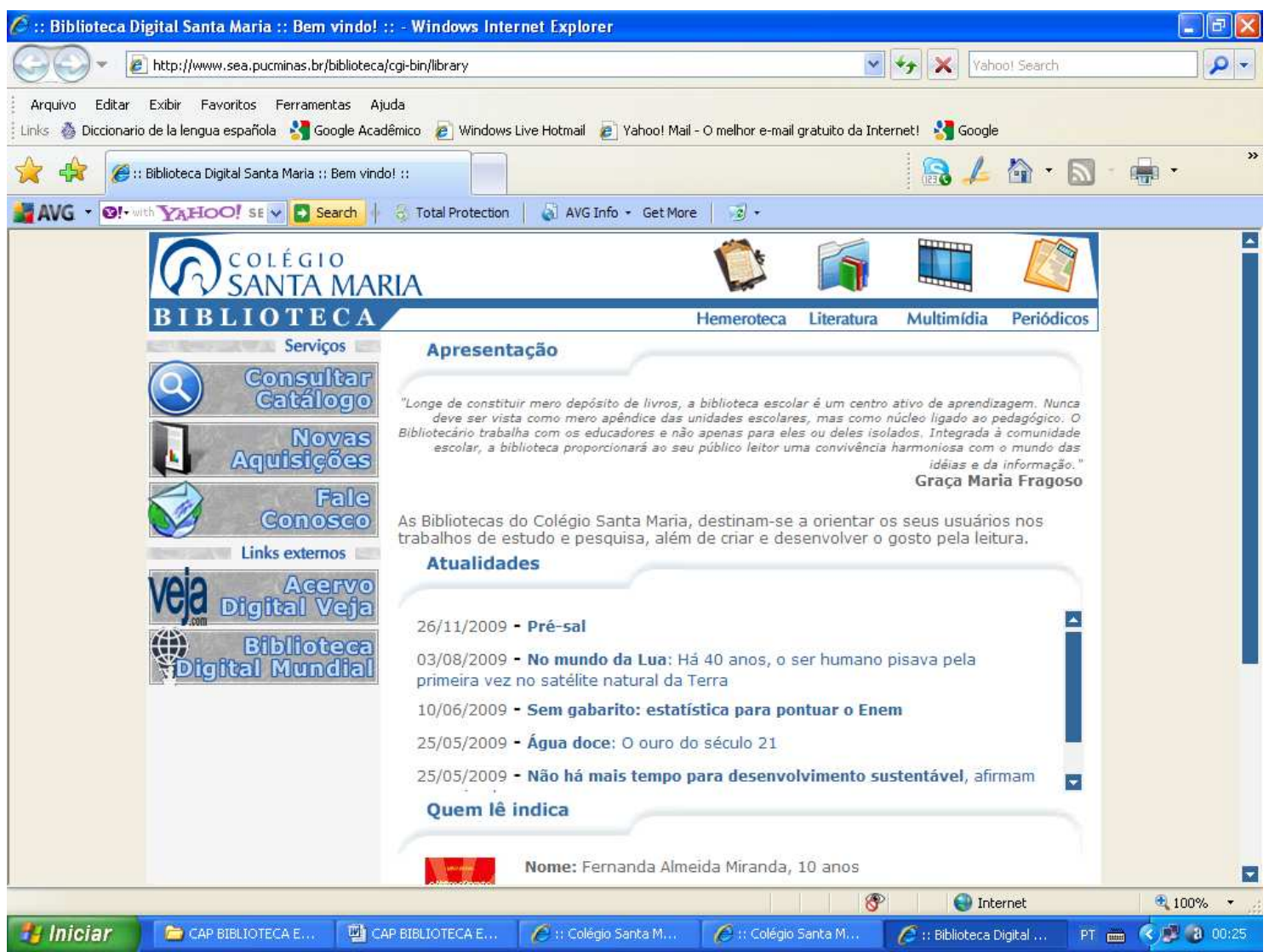

Ressaltamos, ainda, que na Biblioteca Escolar Digital, elaborada pela Fundación Germán Sánchez Ruipére e já mostrada no capítulo três, são apresentados outros recursos e possibilidades viabilizados pelas tecnologias de informação e comunicação, como o hipertexto digital, que vem chamando a atenção dos profissionais da Educação e, também, de

\footnotetext{
${ }^{13}$ Disponível em: <http://www.sea.pucminas.br/biblioteca/cgi-bin/library>.Acesso em: 20 dez. 2009.
} 
uma indústria produtora de conteúdos eletrônicos para as crianças e jovens. Ao mostrarmos a representação de algumas bibliotecas em páginas eletrônicas de escolas públicas e particulares e, também, bibliotecas escolares digitais, buscamos apontar como a rede é meio fértil para a circulação de diferentes discursos e sujeitos, abarcando desde os sentidos de restrição até ambientes que proporcionam diferentes experiências para os sujeitos-alunos. Ainda que raramente existentes no contexto brasileiro, tais recursos, como foi mostrado a partir de projetos em desenvolvimento, podem ocupar um maior espaço no âmbito das práticas educativas, utilizando o suporte eletrônico e as facilidades do hipertexto não como frequentemente se faz nas escolas, de forma parafrástica e infrutífera, mas como oportunidades de construção de sentidos outros sobre os saberes e a biblioteca escolar. A partir da tessitura de outras formas de produção e acesso aos discursos circulantes na escola e biblioteca, quer ocorram na rede, ou no âmbito da biblioteca física, esta pode assumir uma postura mais ampla, configurando-se não mais como um depósito de materiais, inerte e indesejado, mas como uma instituição viva e movimentada por sujeitos, em seus gestos de ler e produzir sentidos além do dominante. 


\section{A BIBLIOTECA ESCOLAR NA REDE ELETRÔNICA: MOVIMENTOS} DISCURSIVOS

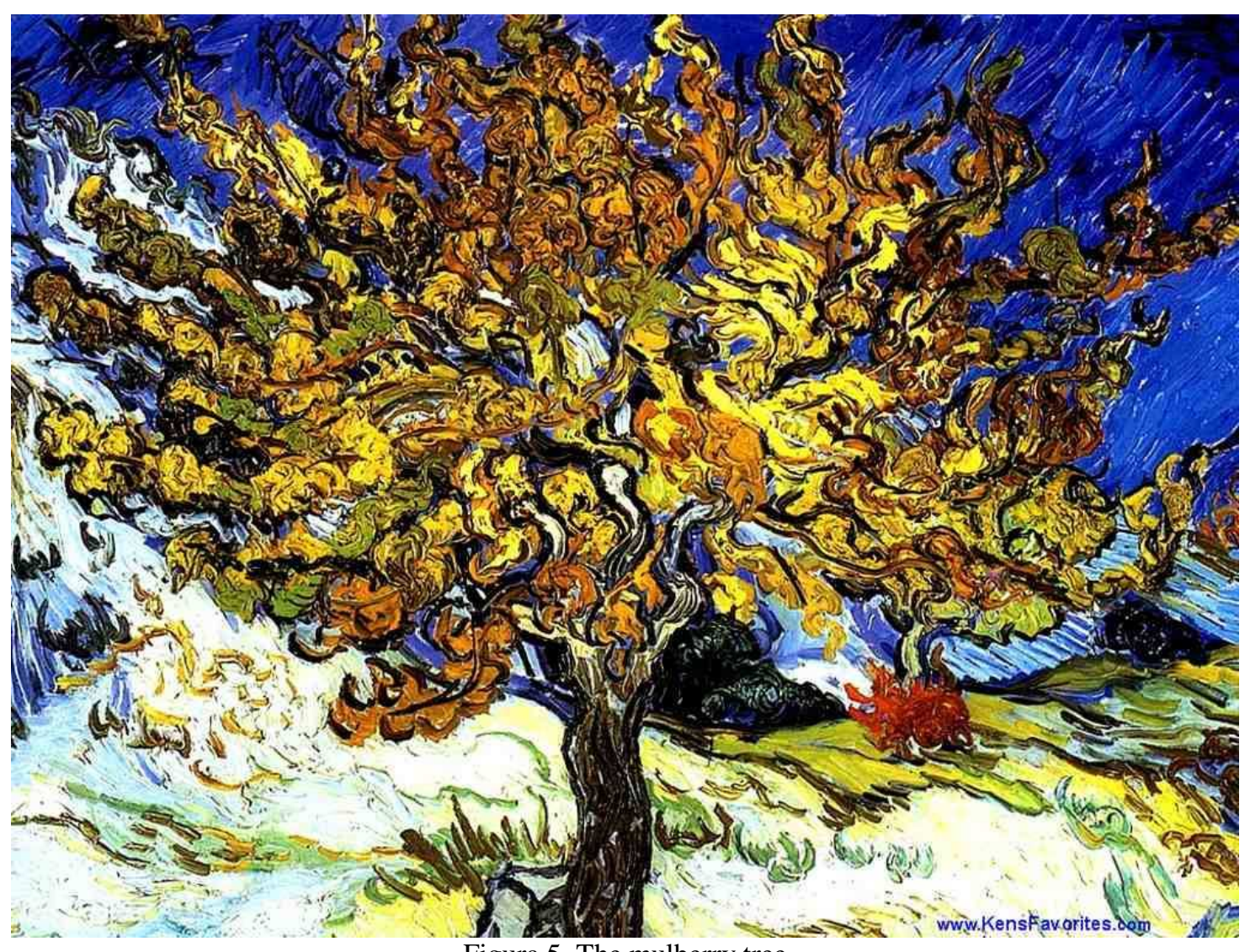

Figura 5. The mulberry tree

"O vento é o mesmo, mas a resposta é diferente em cada folha." (MEIRELES, 1983, p. 156) 
As rotas de navegação que percorremos até aqui nos levaram a investigar, primeiramente, os pressupostos teóricos da Análise do Discurso, que considera a língua como opaca, faltante, passível de falhas e deslocamentos. A partir desse lugar teórico, buscamos compreender melhor como os discursos são materializados na instável teia digital, como se dão os movimentos de sujeitos e a deriva dos sentidos, inscrevendo outros gestos de leitura, que ultrapassem as concepções técnicas e universalistas que circulam nos discursos sobre esse ciberespaço. Interessamo-nos, também, pelo nosso objeto discursivo, a biblioteca escolar, apontando as contraditórias regiões de sentidos que ora discursivizam-na como um lugar valorizado e/ou idealizado, ora significam-na a partir das faltas e problemas que a afetam no contexto brasileiro. A partir desse embasamento teórico, investigaremos quais sentidos foram mobilizados na constituição dos discursos sobre biblioteca escolar que circulam nas redes da Internet, mas, antes disso, apresentaremos o nosso percurso de constituição do corpus e a maneira como iremos analisá-lo.

\subsection{Nas veredas da Internet: rastros de memória e heterogeneidade}

Se a realidade é opaca, existem zonas privilegiadas- sinais, indícios- que permitem decifrá-la. (GINZBURG, 1980, p.177)

Antes de apresentarmos a análise do nosso corpus, julgamos relevante falar um pouco a respeito dos passos dados, nas trilhas da Internet, para chegarmos aos recortes interpretados na próxima seção e, também, àqueles já analisados nos capítulos anteriores. Este percurso teve início após termos realizado uma revisão de leitura acerca dos temas de interesse para esse trabalho, quais sejam, discurso, Internet e biblioteca escolar. Concluída essa primeira etapa, passamos para a coleta de dados, realizada através de constantes pesquisas on-line, tanto em sites especializados da área de Biblioteconomia/Ciência da Informação, quanto em motores de busca como o Google. Nessas buscas, contamos com algumas ferramentas interessantes, que direcionaram o nosso olhar para alguns sítios do ciberespaço, servindo-nos como "tábua de salvação" em meio à pluralidade, à deriva da rede, ajudando-nos a encontrar mais facilmente documentos sobre a biblioteca escolar que nos interessavam analisar. Como exemplo desses recursos utilizados, citamos o cadastro em diversos sites, pelos quais recebemos, periodicamente em nossos correios eletrônicos, mensagens publicadas em listas de discussão (dentre as quais destacamos "Bibamigos"14 e "Bibliotecários, Biblioteconomia,

\footnotetext{
${ }^{14}$ Disponível em: <http://br.groups.yahoo.com/group/bibamigos/>. Acesso em: 10 mar. 2010.
} 
Bibliotecas"15), além de boletins dos conselhos de biblioteconomia ${ }^{16}$. Contamos também com um serviço de alerta de sites $^{17}$, por meio do qual recebemos, diariamente, vários links que nos remetem a novos resultados do Google para o termo "biblioteca escolar", permitindo-nos ter contato, por exemplo, com uma série de textualizações midiáticas referentes ao nosso tema de pesquisa.

Para as buscas de blogs dedicados às bibliotecas e à Biblioteconomia/Ciência da Informação, utilizamos a ferramenta "Pesquisa Google de Blogs"18, que facilitou a nossa procura nas incontáveis teias da Web; dentre os vários blogs pesquisados, selecionamos algumas postagens publicadas em três: "Librarianship"19, "Diário de uma biblioteca escolar" ${ }^{20}$ e "Bibliotequices e afins" 21 . Ressaltamos, por fim, a consulta a um site dedicado à informação jurídica ${ }^{22}$, no qual buscamos a legislação sobre a biblioteca escolar. Deste modo, com o auxílio de tais recursos, tivemos acesso a uma série de outros documentos, que compuseram um extenso e diverso arquivo sobre a biblioteca escolar, um excesso de dados que reclamava um trabalho de seleção. A partir dessa necessidade de delimitação do corpus, escolhemos analisar, neste capítulo, recortes de blogs e listas de discussão, buscando flagrar as vozes dos sujeitos-bibliotecários construindo sentidos sobre a biblioteca escolar.

Observamos que o trabalho de escolher o objeto, determinar o corpus, selecionar os recortes, descrever a análise, apontar as regularidades discursivas e deixar alguns dados de fora já faz parte da análise. Assim sendo, consideramos que o gesto da interpretação do analista de discurso é sustentado pelo rigor teórico de conhecer as ferramentas com as quais trabalha e desdobra-se em algumas etapas (ORLANDI, 2003b): na primeira, passagem da superfície linguística do texto para o discurso; na segunda, a passagem do objeto discursivo para a formação discursiva e, na terceira e última, o deslocamento em direção ao processo discursivo. Em relação ao corpus a ser interpretado, é importante observarmos que, na Análise do Discurso, ele é visto como:

instável e provisório. A delimitação do corpus não segue critérios empíricos (positivistas) mas teóricos. Desse modo, a questão da exaustividade, como já tivemos a ocasião de dizer, adquire novas determinações, ou seja, a exaustividade deve ser considerada em relação aos objetivos e à temática e não em relação ao material linguístico empírico (textos) em si, em sua

\footnotetext{
${ }^{15}$ Disponível em: <http://www.grupos.com.br/grupos/bibliotecarios>. Acesso em: 5 mar. 2010.

${ }^{16}$ Disponível em: <http://repositorio.cfb.org.br/ > . Acesso em: 15 out. 2009.

${ }^{17}$ Disponível em: <http://www.google.com/alerts>. Acesso em: 7 abr.2010.

${ }^{18}$ Disponível em: <http://blogsearch.google.com.br/blogsearch>. Acesso em: 24 mar.2009.

${ }^{19}$ Disponível em: <http://biblio20.wordpress.com/>. Acesso em: 13 ago.2009.

${ }^{20}$ Disponível em: <http://diriodeumabibliotecaescolar.blogspot.com/ >. Acesso em: 21 fev.2009.

${ }^{21}$ Disponível em: <http://bibliotequiceseafins.blogspot.com/ >. Acesso em: 5 abr.2009.

${ }^{22}$ JusBrasil. Disponível em: < http://www.jusbrasil.com.br/noticias >. Acesso em: 5 jun.2010.
} 
extensão. Esse material se organiza em função de um princípio teórico, segundo o qual a relação entre o linguístico e o discursivo não é automática, não havendo biunivocidade entre marcas linguísticas e os processos discursivos de que são o traço (as pistas). (ORLANDI, 2003c, p.10).

Em nosso corpus, buscaremos flagrar as regularidades, as repetições e os deslocamentos, marcas que nos possibilitem refletir sobre como os sentidos são construídos. Analisaremos, portanto, o modo como as pistas significam no discurso, indiciando as relações tecidas entre os diferentes discursos e sujeitos presentes nos vários textos observados. Realizaremos, assim, um trabalho investigativo, reflexivo, buscando os rastros deixados pelos sujeitos, considerando os textos como movimentos discursivos e não os analisando integralmente, pois trabalhamos com recortes, entendidos como a maneira de se instaurar a pertinência e relevância:

São recortes que nos interessam, colocando em relação textos diferentes e que nos mostram propriedades importantes em relação ao tema de nossa pesquisa, na medida em que indicam características dos processos de significação. Esses recortes, por seu lado, não são o fato do analista, mas da relação do analista com o material de análise, na detecção dos processos significativos que nele se inscrevem. Uma vez detectado um processo significativo relevante para o tema e o objetivo da pesquisa, ele deve ser procurado ao longo do corpus, pelos recortes. (ORLANDI, 2003c, p.10-11)

Ressaltamos que não buscamos, através dos recortes selecionados, realizar um simples mapeamento do que foi dito sobre biblioteca escolar. Entendendo a língua como uma prática social, procuraremos analisar as relações existentes entre os sentidos sobre a biblioteca escolar, que foram produzidos por sujeitos filiados a diferentes formações discursivas que nos remetem, por sua vez, às formações ideológicas em jogo com as formações imaginárias, regulando as posições assumidas pelo sujeito para enunciar. Dessa maneira, poderemos observar, no discurso, as relações de poder existentes entre os sujeitos, que determinam o que é possível de ser enunciado sobre a biblioteca escolar, de que modo ele é instado a (se) significar na sociedade, produzindo sentidos que não são transparentes, naturais ou ingênuos, já que se sustentam em relações ideológico-imaginárias, o que incluem os jogos de antecipação de sentidos pelos quais se constroem imagens do/sobre o outro e o objeto discursivo, no nosso caso, a biblioteca escolar.

Buscamos, também, flagrar como alguns sentidos sobre a biblioteca escolar são repetidos e ressignificados por diferentes sujeitos, constituindo um já-dito cristalizado e legitimado. Enquanto isso, outros sentidos são interditados, mas aparecem nas bordas do dizer e, também, no silêncio, que, para nós, é tão significativo quanto a presença de palavras; assim, 
muito mais do que signos virtualizados em uma tela, trabalhamos com a materialidade do funcionamento discursivo, atravessando a cortina do evidente e procurando romper com a literalidade do sentido dominante; vejamos, a seguir, como isso funciona nos recortes analisados.

\subsection{Análise discursiva de dados: vozes que falam da biblioteca escolar}

O que sempre me atraiu, me seduziu na análise de discurso é que ela ensina a pensar, é que ela nos tira as certezas e o mundo fica mais amplo, menos sabido, mais desafiador. (ORLANDI, 2006b, p.2)

Embasadas pela Análise do Discurso de linha francesa, analisaremos um corpus composto por recortes de dizeres de duas listas de discussão e três blogs, nos quais a voz do sujeito-bibliotecário constrói sentidos sobre a biblioteca escolar. Duvidamos da aparente obviedade dos sentidos e julgamos ser o fluxo movediço a condição de dizer no espaço discursivo da Internet que se constitui como um labirinto a ser percorrido de maneira nãolinear pelos sujeitos, no qual emerge a circulação de vozes heterogêneas e justapostas de modo desordenado.

Nosso interesse repousa na escuta da voz desse sujeito-navegador na materialidade da rede eletrônica, em espaços discursivos como os weblogs, ou simplesmente blogs, definidos como diários virtuais, nos quais se pode disponibilizar, além de textos, uma série de recursos como imagens, sons, vídeos, etc. Neles, observamos a exposição de um mosaico de várias vozes emendadas de modo contínuo a fazer (des)enrolar um imenso pergaminho eletrônico onde estão marcadas a voz do sujeito-blogger e as outras tantas vozes de sujeitosnavegadores. As marcas do privado passam a funcionar discursivamente como algo tecido no âmbito da coletividade, ou seja, do público que acessa o blog. Temos, assim, pegadas diversas dos passos de sujeitos implicados e afetados pelo tema ou autor do blog, pegadas estas que nos remetem ao conceito de um discurso permanentemente em construção sem outro fecho a não ser a postagem de cada sujeito. $\mathrm{O}$ efeito de fim é escamoteado e colocado em pausa, suspendendo o instante de acabamento e criando a ilusão de um gerúndio contínuo, que é sustentada pelo movimento de sujeitos em trânsito, conforme nos conta Romão (2006, p.312):

Várias vozes entram no blog para comentar (comments) dados pessoais, enviar contribuições, dicas, orientações (post), endereçar fotografias, polemizar sobre certo assunto e provocar o riso por meio de brincadeiras. Esse jogo de movimentos é o que torna a página atraente, criativa e marcada pela disputa, tensão ou graça (inexistente no antigo diário, no qual se cria o 
efeito de monofonia), posto que a fronteira entre as vozes se camufla sob o efeito de a continuidade interminável de dizeres sobre certa pessoa, questão, tema etc.

Sendo assim, compreendemos o blog como um diário às avessas, no qual o sujeito não escreve para si, em um caderno guardado em lugar secreto, mas para um outro, que lhe é, no entanto, desconhecido. Nesse espaço discursivo heterogêneo, flagramos o constante uso da primeira pessoa do discurso, o que, para nós, indicia uma mudança na maneira do sujeitobibliotecário construir sentidos sobre a biblioteca escolar, a partir da qual sua escrita ganha contornos de intimidade, na medida em que ele se autoriza a manifestar suas opiniões, relatar suas experiências e duvidar dos sentidos já estabilizados, utilizando-se, para tanto, de uma escrita de caráter confessional e coloquial. Isso é possível porque o sujeito é capturado pela ilusão de ser o dono do seu dizer e de ser livre para enunciar, nesse espaço da rede que, supostamente, estaria aberto a tudo e todos, tanto ao sujeito-blogger, quanto aos seus interlocutores, a quem lhes é dada a possibilidade de postar comentários, de entremear-se à rede de sentidos construídos por outros sujeitos.

Observamos que, através do mecanismo das formações imaginárias, o sujeito atribui imagens para si, o objeto discursivo e, também, para o seu interlocutor, a quem, a partir desse lugar, ele se dirige constantemente, para produzir seu discurso, buscando tecer uma relação de proximidade, ao enunciar sobre a biblioteca escolar, instigando-o a refletir sobre aquilo que diz, tentando convencê-lo, à medida que busca antever as imagens que os seus interlocutores fazem dele e do que ele diz, assim como aquilo que eles esperam saber sobre o assunto, dentre outros jogos de antecipação, dados pelas formações imaginárias, que poderão ser observados nos blogs que analisaremos a partir de agora.

Iniciaremos nossa análise com o blog Bibliotequices e afins (APRESENTANDO... 2009), a partir de uma postagem intitulada "Apresentando a biblioteca escolar", que foi publicada no dia 16 de novembro de 2009 (ANEXO 5). Nela, observamos um funcionamento discursivo no qual, a partir do reconhecimento da "imagem tão negativa da biblioteca escolar", procurou-se inseri-la em uma formação discursiva diferente, marcando uma relação de oposição, flagrada na repetição do advérbio "mas", pela qual se busca romper com esses sentidos de restrição (os quais constituem uma rede de paráfrases que atribui um papel estático à biblioteca), ao serem discursivizadas, em seu lugar, a importância e indispensabilidade de uma biblioteca na escola. Ao ocupar esse lugar pra enunciar sobre a biblioteca escolar, o sujeito do discurso está em consonância com as ações que visam à visibilidade da mesma, à apresentação de suas características consideradas desejáveis e que, 
por não estarem instituídas- posto que há "aqueles que nunca entraram em uma biblioteca, nem mesmo para conhecer"-, deveriam ser levadas a todos, "a toda sociedade brasileira", para que todos saibam o que ela deve ser, fazer e ter a fim de que haja mudanças em prol de sua valorização, conforme podemos observar no próximo recorte, no qual o sujeito constrói sentidos sobre um evento dedicado à biblioteca escolar, que foi promovido pelo órgão de classe dos bibliotecários, o Conselho Regional de Biblioteconomia (CRB):

Excelente iniciativa do CRB em mostrar a Biblioteca Escolar através de uma exposição. É uma forma de levar a toda sociedade brasileira o que ela faz, sua importância dentro de uma instituição de ensino e do quanto a biblioteca bem equipada, com um acervo atualizado e uma equipe homogênea comandada por um(a) profissional de biblioteconomia pode ajudar e colaborar com a aprendizagem e o ensino ${ }^{23}$.

Sendo assim, flagramos sentidos que atualizam, no fio do discurso, um já-dito sobre a biblioteca escolar, uma região do já-lá pela qual ela é revestida de características consideradas ideais, as mais adequadas para o seu funcionamento, o que nos remete a outros discursos, circulantes em vários documentos oficiais e científicos, que enfocam a questão do acervo, equipamentos e bibliotecário, para delinear um modelo de biblioteca a ser seguido. Entretanto, no interior dessa rede de paráfrases, flagramos a possibilidade do outro, da polissemia, através de sentidos que discursivizam necessidades de outra ordem, que conferem maior importância ao sujeito-leitor, vejamos:

Os livros são importantes? Sem dúvida. Mas somente as pessoas que frequentam uma biblioteca é que dão vida ao ambiente e aos livros que, enquanto aguardam nas prateleiras sua vez de serem manuseados, ficam temporariamente inanimados, sem vida. E a diferença que uma biblioteca faz na vida de uma criança e de um jovem, sem dúvida é grande se comparado com aqueles que nunca entraram em uma biblioteca, nem mesmo para conhecer.

Assim sendo, atribui-se um lugar de destaque às ações dinamizadoras da biblioteca, que a destituam do lugar estático, associado a um depósito de livros, significando-a a partir de discursos mais luzentes, cheio de cores e sons, que nos remetem à circulação de sujeitos e sentidos, o que também é materializado no seguinte recorte: "uma biblioteca escolar não é somente um repositório do saber mas sim, um espaço alegre, vivo, onde as pessoas se encontram, interagem e trocam informações e reforçam as amizades." Deste modo, inferimos que, dentre tantos sentidos que o sujeito poderia mobilizar para enunciar sobre a biblioteca, são postos em discurso aqueles que buscam significá-la a partir de uma formação

\footnotetext{
${ }^{23}$ Todos os grifos nos recortes são nossos
} 
discursiva em que são dominantes os sentidos de importância e valorização; entretanto, notamos, aqui, um funcionamento discursivo diferenciado, pelo qual não são apontados apenas os aspectos pedagógicos e as condições ideais de funcionamento, mas são priorizadas as relações que se dão no interior da biblioteca, tomada como um espaço social, parte da vida cotidiana dos sujeitos-leitores, um lugar de encontros, de afetos, no qual não caberia o silêncio, sendo marcado pelo movimento, que lhe confere contornos de uma biblioteca viva, orgânica, oposta a uma biblioteca escolar discursivizada a partir de sua fisicalidade, seus aspectos materiais, que tanto são repetidos nos documentos oficiais e científicos, conforme já abordamos no capítulo 4.

Essa outra maneira de inserir a biblioteca em um lugar discursivo de importância é reforçada pelo uso de metáforas relacionadas ao corpo, conforme podemos ver no seguinte recorte: "Uma escola sem biblioteca é como um corpo sem coração e cérebro. Faltando conhecimento e o acesso a ele, e faltando calor e atenção, qualquer escola fica 'aleijada' sem esse espaço tão significativo". Deste modo, a biblioteca escolar é dotada de tanta importância quanto um órgão vital, o que significa que a sua falta marca os sujeitos escolares de forma irreparável, significando uma ausência que aleija, que mutila, que afeta o sujeito em sua própria constituição; sendo assim, a biblioteca não é mais uma vez falada como o suporte, o apêndice, um complemento cuja falta não acarretaria tantos problemas, mas como imprescindível, visto que, sem ela, a escola não poderia mais atuar de forma adequada.

Outra diferença posta em discurso nesse blog é flagrada quando o sujeito, ao invés de relacionar esses sentidos "ideais" de biblioteca escolar a uma possibilidade futura, mobilizaos para discursivizar o seu dia-a-dia, apontando-nos a existência de bibliotecas em que tais sentidos de vida e movimento circulam não apenas na esfera do discurso, mostrando-se uma possibilidade real que, por vezes, parece-nos muito distante, sendo pouco discursivizada:

Nesse exato momento, olho sob a tela de meu computador e observo as mesas das bibliotecas ocupadas por jovens do ensino médio que estudam, debatem, conversam, tornando o espaço cheio de vida e alegria.

Essa outra maneira de discursivizar a biblioteca, como um espaço vivo e dinâmico, é legitimada quando o sujeito atribui a si mesmo, pelo jogo de formações imaginárias, um lugar de saber e poder, a partir de sua experiência, criando-se, então, um efeito de veracidade ("tenho a plena certeza") para o que ele enuncia a partir desse lugar. Observamos também que essa vivacidade indicia uma outra forma de atuação desse sujeito bibliotecário, que rompe com o foco concedido comumente à atividades de manutenção e organização da biblioteca, privilegiando aquelas que colocam sujeitos e obras em movimento. Destacamos ainda que, ao 
ocupar a posição de bibliotecário para enunciar, o sujeito se identifica com o discurso do $\mathrm{CRB}$, apontando o sucesso de suas ações em prol do reconhecimento da biblioteca, que o leva a instigar a realização de outras atividades, contando, para tanto, com o apoio de seus interlocutores, conforme podemos observar a seguir:

Sei que para muitos, pode até parecer que estou sendo tendenciosa em defender tanto esse espaço mas, vamos ser sinceros: Como não elevar um ambiente que convivo há tantos anos e que devido a essa experiência, tenho a plena certeza que é algo benéfico para o estudante professores e todos que a frequentam? Parabéns mais uma vez a essa iniciativa que o CRB e todos os órgãos ligados a bibliotecas estão fazendo para que mude de vez essa imagem tão negativa da biblioteca escolar. Vamos reforçar esse apoio? Contamos com vocês!

No recorte apresentado, pudemos flagrar o funcionamento de um jogo de antecipações, pelo qual o sujeito tenta antever a imagem que o seu interlocutor constrói daquilo que ele enuncia, como podemos ver em "sei que para muitos, pode até parecer que estou sendo tendenciosa em defender tanto esse espaço". A partir dessa antecipação de sentidos, o sujeito tenta construir, controlar o seu discurso de uma maneira pela qual ele acredita que será bem compreendido. Inferimos que esse movimento acontece porque o sujeito tem a ilusão de que pode governar a produção do seu discurso (esquecimento número dois), de maneira que este "traduza" exatamente o seu pensamento, esquecendo-se, assim, de que é afetado pela ideologia (esquecimento número um), não sendo o dono dos seus dizeres.

Ressaltamos ainda que, no bojo dessas relações imaginárias, o sujeito busca construir uma empatia com o interlocutor, tenta aproximar-se dele, fazendo com que ele aceite o convite de juntar-se àqueles que empreendem ações em prol de uma mudança da "imagem tão negativa da biblioteca escolar". Marcamos que esse chamamento à ação ganha, nas redes da Internet, outra configuração, em que, através das possibilidades de interação, instaura-se um espaço aberto ao diálogo, à heterogeneidade de sentidos em consonância, e/ou discordância, conforme podemos observar nos próximos recortes, que correspondem a comentários tecidos sobre a postagem analisada:

Excelente post! Precisamos de mais iniciativas assim! Continuaremos a lutar por melhores condições para as bibliotecas escolares.

Oi, Roseli!!! Parabéns pelo trabalho...Li teu texto e a imagem da biblioteca da escola em que trabalho me veio à mente: quase vazia... sem uso... São poucos os professores que levam as turmas até lá... arrisco dizer que apenas os do curso normal...Um bom acervo... meio atirado... os livros novos, que o MEC tem enviado, estão fechados em armários...Sem bibliotecári@... 
Ano que vem, com a nova equipe diretiva... quem sabe...Sonho com bibliotecas como a tua!!! Abraços!!

Oi Suely!!! Obrigada mais uma vez por sua visita. É sempre um prazer. Sabe, sonho com o dia em que todas as escolas terão uma biblioteca à altura do aluno e dos professores. Um espaço de troca de informações, aprendizado e lazer. Não perco a esperança não. Um dia isso será realidade aqui entre nós brasileiros. Bjs

A partir dos recortes apresentados, pudemos flagrar sentidos que atravessam o discurso do sujeito-blogger, indo ao encontro do que foi enunciado por ele, na medida em que o sujeito não só se identifica com a região de sentidos que discursiviza as ações em prol da valorização da biblioteca escolar ("excelente post! Precisamos de mais iniciativas assim", “parabéns pelo trabalho"), como também assume o lugar de combatente ("Continuaremos a lutar"), nessa batalha para a qual ele foi chamado, pelo sujeito-blogger. Por outro lado, inferimos que a interatividade que marca as ferramentas dadas pelo hipertexto e evidencia a heterogeneidade do discurso, promove a possibilidade de outros sentidos sobre a biblioteca escolar, instalando uma pluralidade que faz falar, no interior do mesmo, o diferente, como podemos observar nos dois últimos recortes de comentários de sujeitos-leitores do blog; neles, flagramos um embate entre os sentidos de uma biblioteca viva e movimentada, que foram discursivizados pelo sujeito-blogger, e aqueles que significam a biblioteca escolar a partir da falta e da interdição, ressaltando a ausência de leitores e de bibliotecários, a presença velada de livros, que estão trancados e não sendo lidos, enfim, sentidos estes que colocam, mais uma vez, em discurso as práticas restritivas nas bibliotecas escolares, sugerindo que os sentidos enunciados pelo sujeito-blogger não são ainda dominantes em um contexto educacional brasileiro, marcado por dificuldades. Entretanto, apesar de tais problemas, enuncia-se de uma forma esperançosa, pela qual se sonha que um dia essa biblioteca viva possa ser enunciada por outros sujeitos também.

Em uma pequena postagem do blog Librarianship (ANEXO 6), do dia 6 de novembro de 2008 (MINHA..., 2008a), selecionamos alguns recortes para serem analisados, que abordam o relato de um sujeito que também ocupa a posição de bibliotecário para enunciar sobre a biblioteca escolar; neles, também observamos sentidos de ruptura, que inscrevem a biblioteca em outro lugar, não mais de abandono, mas de empenho, realizações e valorização:

Comecei minhas atividades no último dia 23 e para mim tem sido um aprendizado muito grande. É verdade que a vontade de 'mudar o mundo' de um dia para outro, logo vem à cabeça. Mas as coisas não caminham e nem funcionam desse jeito. É necessário muita cautela. Mas quero contribuir o máximo que posso para que a biblioteca seja realmente um lugar onde as crianças- neste caso por ser uma biblioteca escolar- 
possam encontrar um bom livro para ler e, acima disto, um lugar agradável também. E minha primeira tarefa é... contar histórias para crianças da $4^{\mathrm{a}}$ série em uma 'tarde de autógrafos' marcada pela professora de literatura, onde os alunos irão autografar para os pais os livros por ele mesmos confeccionados. E assim espero eu contribuir para a implementação de projetos outrora 'estacionados' e que agora, quem sabe, podem voltar a ser realizados a partir da força de vontade de cada um de nós envolvidos na biblioteca. Acreditar vale a pena...

Assim sendo, a biblioteca não é discursivizada aqui como desacreditada, a partir de sentidos que enfatizam as contínuas e, aparentemente, perenes restrições sofridas, mas como um lugar de realização, cujas ações em seu benefício valeriam a pena. Nessa perspectiva, o sujeito assume uma postura ativa, assim como a biblioteca, que passa de depósito inerte a um vasto campo de possibilidades de aprendizagem ("tem sido um aprendizado muito grande") e atividades instigantes, em parceira como os professores ("tarde de autógrafos", “contar histórias"), indiciando a já mencionada importância de que a biblioteca esteja integrada à escola. A partir dessa ótica, a biblioteca é tida como desejável e o sujeito enuncia com entusiasmo e otimismo acerca das ações que podem colocá-la em movimento, na medida em que ele constrói para si mesmo uma imagem de poder e prestígio, pela qual teria grande importância para a melhoria das bibliotecas escolares, como podemos observar nas marcas "vontade de "mudar o mundo", "quero contribuir o máximo que posso", "espero eu contribuir", "força de vontade de cada um de nós", "acreditar vale a pena". Por conseguinte, através dessa perspectiva, a biblioteca escolar é vista como "um lugar agradável", em que se pode ler "um bom livro", silenciando uma série de outras representações menos coloridas que poderiam estar em seu lugar. Entretanto, como isso ainda não é recorrente no cotidiano escolar, instala-se a contradição, outra região de sentidos que atravessa o discurso e é flagrada nas formulações "Mas as coisas não caminham e nem funcionam desse jeito. É necessário muita cautela" e "projetos outrora 'estacionados"”; a partir delas, o sujeito reconhece os problemas existentes e, diante deles, não enuncia de forma lamentosa, mas esperançosa e implicada, marcando uma regularidade, uma maneira do sujeito-bibliotecário construir sentidos sobre a biblioteca escolar brasileira, que observamos, também, na análise de outros recortes, como aqueles discursivizados no blog Diário de uma biblioteca escolar (DESESPERO... 2008), no dia 6 de março de 2008 (ANEXO 7). Neles, podemos observar como esses problemas que envolvem a biblioteca escolar são enunciados de uma maneira diferente, instalando outros efeitos que não os de repetição. Nessa postagem, o sujeito atualiza sentidos de restrição, ao relatar algumas práticas realizadas nas bibliotecas, e, diante disso, discursiviza, de maneira particular e informal, a sua relação com a biblioteca e 
com o seu fazer bibliotecário, as dificuldades enfrentadas quando se tenta cumprir sozinho todas as atividades consideradas necessárias, do cadastramento dos livros à mediação do acervo:

Cara, tem dia que dá um desespero total neste lugar. Imagine, 10.000 livros para cadastrar e gente te pedindo livros didáticos que você não sabe se tem, assuntos temáticos que exigiriam um resumo dos livros... você fica louco se levar muito a sério. O que eu faço? respiro fundo e vou. Sento com meus usuários alunos para ver do que eles precisam e como vão indo nas matérias, fico atento aos professores e pesquiso coisas antes até que me peçam, mexo com a cabeça dos alunos da forma que consigo para levarem a sério os estudos e lerem também a leitura do prazer.

Assim, diante das dificuldades encontradas e o desespero que elas causam, o sujeito precisa priorizar algumas atividades, em detrimento de outras. No discurso em questão, discursiviza-se a transgressão a uma prática recorrente, no âmbito da Biblioteconomia/Ciência da Informação e extensamente parafraseada nos documentos oficiais e científicos sobre a biblioteca escolar, que se refere a conferir grande importância, prioridade ao tratamento do acervo, conforme podemos flagrar no recorte: "não me importo de não catalogar 1000 livros por dia, mas me importo se não conseguir uma boa linha de comunicação com os estudantes"; opta-se, assim, por enfocar a relação com os "usuários alunos", o estímulo à leitura e à pesquisa, inaugurando outros sentidos sobre a biblioteca escolar, pelos quais ela assume um lugar de destaque, ao atrair, instigar os sujeitos-leitores a frequentarem-na, a inserirem-se nela, para produzirem outros gestos de leitura e escrita, instalando uma relação diferente com a leitura, não mais a leitura obrigatória, valendo nota, mas a "leitura do prazer", que alarga o horizonte da biblioteca escolar, que não pode ser considerada como uma instituição que apenas serve ao currículo escolar, devendo ir além, a partir de uma postura mais ativa. Sendo assim, a biblioteca escolar deixa de ser um lugar passivo, de espera, para colocar-se em movimento, indo ao encontro do sujeito-leitor e de suas necessidades, estimulando-o, buscando conhecê-lo, como podemos observar nos recortes: "pesquiso coisas antes até que me peçam", "mexo com a cabeça dos alunos", "comunicação com os estudantes", “o diálogo e o início de um aprendizado diferenciado está vindo a partir do meu levantamento sutil de preferências".

Observamos que esses sentidos a respeito de práticas que consideramos mais frutíferas vão de encontro àqueles que discursivizam uma postura "antiquada", nociva, por parte da escola em relação à biblioteca, instalando um litígio que pode ser flagrado na ordem da língua, como podemos observar nos seguintes recortes: 
Esta comunicação está acontecendo aos poucos, uns eu contacto via orkut (de fora pois a escola, por ser antiquada, não permite que os alunos acessem e que eu possa com eles manter um diálogo no meio em que gosta e estão acostumados

É certo que eu tenho alguns impecilhos (sic) por aqui. Uma pessoa que dá bronca quando um aluno desenha na lousa da biblioteca) porque pediu minha permissão e eu deixei ele se expressar, uma escola que manda os alunos que não tem o livro 'de castigo' para a biblioteca e os que chegam atrasados também. Professores não leitores que querem que os alunos leiam e um certo descaso com as necessidades da biblioteca por livros mais atualizados e até por uma impressora que imprima as etiquetas corretamente. Mas, fora isto a biblioteca vai bem e um tanto quanto orgulhosa pelos elogios recebidos de professores como: 'fico feliz em ver que a biblioteca está viva, ela conversa com a gente'...? (coloco bilhetes por todos os lados..propaganda subliminar para fazer os alunos a repensarem sua repulsa por leitura.

Ressaltamos, neste discurso, a retomada de sentidos historicamente mobilizados para fazer falar a postura rígida e limitada da escola perante os sujeitos-escolares, a leitura e a biblioteca, a qual é significada mais uma vez como um lugar de castigo, onde não se pode expressar-se, sendo dominantes os sentidos de negação e privações, tanto no que diz respeito às ações praticadas, quanto aos recursos de que necessita. Perante essa situação, o sujeito ocupa uma posição discordante e inscreve sentidos que furam essa formação discursiva, instalando uma oposição ("mas, fora isto") entre uma escola "antiquada" e uma biblioteca "viva", dinâmica, que é merecedora de elogios, causa de orgulho, graças a algumas práticas “estranhas" praticadas pelo sujeito e discursivizadas no blog:

Ando colando poemas chão do colégio afora e acho que para estes tenho mais leitores do que para os livros. Fiz algumas pilhas de livros no chão de modo que tropecem e derrubem.. sei que pode surgir algum diálogo a partir dessas coisas 'estranhas' que tenho feito.

A partir dessas ações não convencionais, o sujeito-bibliotecário instala outra maneira de falar sobre a biblioteca escolar e a prática profissional bibliotecária, significando o seu esforço de instigar sujeitos-leitores, com os quais busca tecer um diálogo e vivificar sua biblioteca. Em outros recortes do blog Diário de uma biblioteca escolar (MINHA... 2008b), publicados no dia 10 de março de 2008 (ANEXO 8), encontramos também sentidos mais polissêmicos em relação às práticas realizadas na biblioteca escolar:

devo tomar um café para prosseguir com a brincadeira feliz de estar nessa biblioteca, atender almas sedentas daquilo que nem sabe que estão, dar comida invisível a mentes voláteis. [...] não vejo a hora de voltar para os meus amigos livros e para meus clientes, os usuários. Diversão sem 
preço. Olho pela porta para ver se não caiu nenhum inseto em minha teia. ainda não. Hoje de manhã consegui pegar uma mosquinha na teia.

Através de metáforas relacionadas a fenômenos naturais como a "avalanche" e o "terremoto", o trabalho em uma biblioteca é discursivizado a partir de seu caráter dinâmico, impactante, movimentado, pelo qual ele não é tomado como desinteressante ou monótono, mas como uma "brincadeira feliz", uma "diversão sem preço", em que se busca atrair o sujeito-leitor, abrindo espaço para a emergência de outras posições-sujeito, de outras funções para as bibliotecas, vistas nesse discurso não apenas como auxiliares à educação, mas como fundamentais, já que concedem o "alimento" que sustenta o aluno, em seus percursos no âmbito escolar e fora dela. A partir dessa concepção, os sentidos que legitimam o silêncio e a ordem rígida em uma biblioteca seriam desconstruídos:

Eles iam sentando, aos pouco. Sempre perguntando muito, mexendo em tudo...santa bagunça eu adoro isto! Prefiro do que o gelo de nada fazer e nada ter para fazer...adoro arrumar a bagunça quando eles saem. São uns furacõezinhos maravilhosos que me enchem a alma de esperança nos leitores do futuro. Perguntadeiros, conversadeiros, espertos pedacinhos de gente. Peguei um livro que não fosse muito extenso e comecei a contar uma história de uma princesa, a princesa 'Mãe d'água'. [...] Eu quero mais é que eles venham e derrubem tudo. Construo de novo com o maior prazer.

A biblioteca escolar é discursivizada, então, como um lugar vívido, que permitiria a emergência de sujeitos-leitores, instalando um lampejo de esperança, em meio aos sentidos que evocam o desprestígio conferido à leitura, que é mostrado no excerto a seguir: "Ah que inveja os livros de romance sentem dos livros didáticos. Se pudessem acompanhar aquelas crianças nas aulas, ficariam quentinhos ali, guardados nos armários esperando a hora de serem folheados e lidos". A partir desses dizeres, o sujeito denuncia que as atividades pedagógicas são calcadas no livro didático, abrindo-se pouco espaço para outras leituras, acarretando, assim, a sub-utilização da biblioteca, vista não raramente como um almoxarifado, resumida a um armário para alocar os livros didáticos utilizados em sala de aula. Observamos que esses sentidos são desestabilizados quando se discursiviza uma biblioteca escolar mais maleável, flexível, que não se preocupa só em conservar, mas em fazer circular obras e sujeitos, postos em movimento através de atividades de leitura e mediação do acervo, relatadas em tom confessional, pelo sujeito-bibliotecário: "e esta foi a minha primeira hora do conto. Espero melhorar muito, mas gostei do que senti ao contar a história". Por fim, inferimos que estas atividades de promoção de leitura, dentre muitas outras a serem realizadas na biblioteca, nunca se dão por terminadas, pois uma biblioteca viva 
implica movimento, uma constante ruptura da ordem, que não é a sua função mas apenas o meio de permitir novas fraturas, de reconstrui-la “de novo com o maior prazer".

Em uma postagem do blog Librarianship (AFINAL..., 2009), publicada no dia 19 de setembro de 2009 (ANEXO 9), flagramos uma formação discursiva que vai de encontro a essas práticas mais plurais discursivizadas nos recortes anteriores, fazendo circular os sentidos de restrição que conferem à biblioteca uma imagem alinhada à arcaica concepção de um depósito fechado de livros. Esses sentidos circulam a partir das críticas à falta de acesso aos acervos, o que pode ser visto ver nos recortes que seguem.

Existe uma certa tendência dentro das bibliotecas- principalmente das escolares- de que nem todo acervo seja emprestado. Talvez, isto seja um sinal de que fungos, traças e mofos possam também ter acesso aos livros.

A desculpa mais usada, talvez seja a de que as crianças irão destruir o livro e por isso é melhor conservá-lo, trancafiado dentro dos armários. E nisso tudo o que mais preocupa é que essa tendência não se restringe apenas às bibliotecas.

Essa prática de restrição do empréstimo é vista nesse discurso como algo recorrente e generalizado, visto que se tornou uma "tendência", não apenas das bibliotecas escolares, mas de vários órgãos governamentais, que também teriam esse hábito não justificável, já que é necessária uma desculpa, um pretexto para praticá-lo. A partir dessa perspectiva, são retomados, pela memória do discurso, os sentidos historicamente empregados para falar sobre as bibliotecas, como a medieval, associada a um lugar inerte, que funciona como um depósito, cuja função seria a de resguardar e conservar os materiais, a partir de uma lógica inóspita pela qual se evitaria o manuseio; ao serem ressignificadas dessa maneira, a biblioteca escolar e sua missão não estariam direcionadas para os sujeitos-leitores, mas sim para os bens materiais alocados na biblioteca, perpetuando uma concepção restrita, na qual se inserem outras práticas como a preocupação excessiva com as atividades de organização e catalogação, em detrimento da disseminação, e a política de distribuição de livros, ao invés de outras que os dinamizassem.

Dessa maneira, a biblioteca continua assemelhando-se a uma prisão para livros (sentido este flagrado em outros recortes), aos quais "fungos, traças e mofos" teriam acesso privilegiado, construindo, assim, uma imagem muito distante daquela preconizada em uma "sociedade da informação", que prega a liberdade como valor supremo. Por meio de indagações direcionadas ao seu interlocutor, o sujeito desse discurso, ocupando a posição de bibliotecário, enuncia sobre a restrição do empréstimo de forma a desautorizá-la, pois ela 
estaria associada a uma infração de um princípio bibliotecário que deveria ser obedecido e levado em consideração no cotidiano das bibliotecas:

De acordo com Ranganathan todo livro é para ser usado. Mas então por que nem todos são emprestados??? Por que comprar um livro e depois colocar que o mesmo não pode ser emprestado?

Esse vício 'anti-primeira lei da biblioteconomia' deveria ser extinto em âmbito nacional. Se este não for possível, dadas nossas proporções, que seja pelo menos no âmbito das bibliotecas.

Observamos, assim, através do litígio entre as normas bibliotecárias e o que é praticado nas escolas brasileiras, que esse discurso é atravessado pela heterogeneidade, a fim de desestabilizar os sentidos de restrição em relação à biblioteca, fazendo com que a proibição do empréstimo seja enunciada como algo nocivo, um "vício" que deve ser "extinto" e que é denunciado, posto em cheque pelo sujeito desse discurso; marcamos que, através de suas interrogações, o sujeito instala um furo no discurso, desautorizando-o, duvidando dos sentidos tidos como naturais, pela força da repetição, e abrindo uma brecha para a entrada de outros.

No blog Librarianship (BIBLIOTECA..., 2009), em uma postagem intitulada "Biblioteca escolar: algumas considerações" (ANEXO 10) publicado no dia 7 de julho de 2009, nós observamos como alguns outros sentidos de restrição foram postos em discurso para significar a biblioteca escolar. Marcamos que as "considerações" aludidas no título da mensagem referem-se à "situação das bibliotecas escolares brasileiras", ou seja, como elas são, estão, e não como deveriam ser/estar, o que nos remete a uma das regularidades encontradas em pesquisas anteriores, pela qual temos uma formação discursiva em que se inscrevem sentidos de restrição ao serem enunciados os vários problemas enfrentados por essa instituição, conforme já adiantamos no capítulo 4. Esse sempre-já-aí é indiciado pelo efeito de obviedade, do que é conhecido por "todos" e que está posto nesse discurso, funcionando através das marcas linguísticas "já", "lógico", "por sinal", "nitidamente" e "claro", utilizadas para discursivizar a difícil situação das bibliotecas escolares e, mais amplamente, da educação, como podemos observar nos recortes que se seguem:

situação das bibliotecas escolares brasileiras e, que por sinal, todos nós já conhecemos.

é lógico que existem problemas que só servem para degradar a educação já tão sucateada.

'rixa' (não generalizando, é claro) entre professores e bibliotecários, vista nitidamente em muitas escolas. 
O emprego desses termos, juntamente com o dos advérbios de intensidade ("tão" $\mathbf{e}$ "muitas"), sugere que as dificuldades pelas quais passam as bibliotecas escolares são várias e corriqueiras, já enunciadas e naturalizadas pela repetição em vários outros discursos, presos na circularidade do sentido dominante. Assim sendo, observamos uma região do interdiscurso da qual emergem sentidos de deteriorização, conforme podemos observar nas marcas "degradar" e "sucateada". De maneira semelhante, são discursivizados os livros e a leitura, como podemos observar a partir dos sentidos de denúncia acerca dessa situação vigente:

o que não acredito, e isso serve para a educação como um todo, são em ações de cunho explicitamente filantrópicos, como por exemplo encher os alunos com kits de livros (que posteriormente são queimados, jogados no lixo e etc) desejando que os mesmos leiam a qualquer custo, quando na verdade a prática de leitura está anos-luz de distância destes por razões de cunho social, econômico e familiar.

Sendo assim, o sujeito enuncia a partir de uma posição crítica e contrária às ações que visam apenas à distribuição de livros (já abordada nos capítulos 2 e 4), duvidando ("não acredito", "na verdade") dos sentidos legitimados pelo dizer oficial de que tais políticas solucionariam o problema da educação e da leitura, ao discursivizarem um leitor homogêneo, desconsiderando os fatores "de cunho social, econômico e familiar" que afetam a tomada da palavra, assim como os gestos de leitura, que, inscritos nessa perspectiva burocratizante e obrigatória, em que se deve ler "a qualquer custo", não suscitariam o prazer de estar em meio aos livros, em uma biblioteca. Inseridos nesse lugar desprestigiado, os livros são vistos como algo que não serve para nada, como resto, algo ruim, que merece como destino o "lixo", e a leitura é algo afastado do cotidiano escolar, a "anos-luz de distância", assim como a biblioteca, como sugerem as discordâncias, as "rixas" entre os professores e bibliotecários, de que falamos no capítulo 4 e ferem uma das condições para que uma biblioteca se aproxime da imagem tida como ideal, qual seja, a integração entre sala de aula e biblioteca, entre a comunidade escolar e o bibliotecário.

Observamos que essa perspectiva contrapõe-se aos sentidos que consideram estar em curso uma "mudança quanto à valorização" das bibliotecas, que seria acompanhada de uma produção científica que "tende aumentar"; entretanto, a partir do que foi exposto anteriormente, inferimos que essas mudanças em direção a uma biblioteca escolar mais valorizada, viva e próxima dos sujeitos-leitores não constituem ainda um sentido dominante, sendo extensamente repetidos os sentidos de restrição, que perpassam a esfera escolar, política e científica. Um exemplo do que estamos falando foi encontrado na lista de discussão Bibliotecários, Biblioteconomia, Bibliotecas (BIBLIOTECA..., 2008), na qual foi postada 
uma mensagem intitulada "Biblioteca escolar (desrespeito ao espaço)", no dia 15 de outubro de 2008, transcrita integramente a seguir:

Boa tarde colegas, tem algum tempo, que a biblioteca escolar em que trabalho vem sendo desrespeitada por coordenadores pedagógicos e professores que insistem em deixar alunos de castigo na biblioteca, estes alunos se revoltam e acabam detestando a biblioteca. É uma situação muito delicada, todos os dias tenho que ficar cuidando de alunos mal criados na biblioteca, que muitas vezes permanecem trancados lá durante todo o período de aula. Grata.

Assim como em outros recortes, temos aqui os sentidos que atribuem às práticas cerceadoras um caráter rotineiro, insistente e repetitório, marcadas na ordem da língua pelo uso do gerúndio e termos que expressam longa duração de tempo, delineando uma "situação muito delicada", difícil, que "vem sendo" praticada "tem algum tempo", “todos os dias", “durante todo o período de aula". Através desses sentidos imaginariza-se a biblioteca como um lugar indesejável, desrespeitado e detestável; marcado pelo castigo, como um lugar de “detenção" para "alunos mal criados", revoltados e indesejados na sala de aula, um lugar tão ruim que serviria como punição.

Como todo dizer cala outro, inferimos que, ao ocupar este lugar de desprestígio, a biblioteca deixa de ser falada como uma instituição dinâmica, um centro de aprendizagem, aberto para a leitura prazerosa, dentre outros sentidos circulantes em outra formação discursiva. Do mesmo modo, ao construir para si a imagem daquele que vigia livros e alunoso que pode ser observado no período: "eu tenho que ficar cuidando de alunos mal criados"-, o sujeito-bibliotecário deixa de ocupar uma posição diferente, a partir da qual ele poderia inscrever sentidos outros, que discursivizassem o movimento de livros e sujeitos na biblioteca, que transformassem esse espaço de castigo em uma possibilidade de conquista de um leitor, construindo outros discursos para a leitura e a biblioteca, que pudessem ir de encontro ao seu isolamento e submissão, as quais indiciam as práticas educativas restritas, punitivas e desestimulantes regularmente encontradas no contexto escolar.

É interessante observarmos, nos recortes do blog Bibliotequices e afins (ESCOLAS..., 2009) que foram publicados em 1 de dezembro de 2009 (ANEXO 11), como os sentidos de obviedade, anteriormente relacionados aos problemas das bibliotecas escolares, circulam em outra formação discursiva, na qual se considera sua relevância (reconhecendo a "importância da biblioteca numa escola"). A respeito do título da postagem "Escolas deveriam ter biblioteca na grade curricular", destacamos que o uso do verbo no futuro do pretérito indicia uma condição inexistente, através do pressuposto de que se as escolas deveriam ter biblioteca, 
é porque elas ainda não têm. Partindo dessa premissa, o sujeito tece sentidos de denúncia, instalando uma formação discursiva de resistência, pelo uso das marcas linguísticas que conferem ao discurso um sentido de obviedade:

Na boa, disso eu já sei faz é tempo! Mas, de qualquer maneira, me alegro ao ver que pouco a pouco, pessoas de expressão em nosso país tomam consciência da importância da biblioteca numa escola.

Observamos que, a partir das funcionalidades oferecidas pelos recursos hipertextuais, que possibilitam outras formas de produção e circulação de sentidos, a heterogeneidade ocupa um lugar privilegiado na rede eletrônica, que pode ser observado na prática costumeira de disponibilizar em um blog os dizeres encontrados em outros blogs ou qualquer outro ponto da grande teia digital. O discurso analisado foi selecionado pelo sujeito como um arquivo de interesse (processo que é da ordem do ideológico, frisamos), dentre uma série de outros possíveis, recortando algumas regiões do interdiscurso pelas quais, é instado a significar, valendo-se para tanto, de diversas possibilidades dadas pela interatividade. A partir dessas possibilidades, os sentidos materializados no recorte anterior configuram-se como uma resposta aos que estão postos a seguir:

na minha opinião, a escola deveria ter uma hora de biblioteca na grade curricular, como um momento de prazer num ambiente agradável.

Perante tal afirmação, em que se discursiviza a biblioteca a partir das suas características faltantes e ideais, referentes à leitura prazerosa e a um ambiente agradável, o sujeito produz sentidos que inscrevem essa instituição e as recomendações acerca da mesma no lugar do já conhecido, do que já se sabe há tempos, mas que ainda não foi praticado e nem constatado, como se pode observar no recorte seguinte:

Basta agora, essas mesmas pessoas aliadas aos profissionais de bibliotecas se empenharem em levar ao resto da sociedade essa constatação.

De maneira semelhante ao que vimos em outras análises, o empenho dos profissionais envolvidos com a biblioteca e da sociedade em geral também é visto aqui como fundamental, para que as bibliotecas possam passar da teoria, do que deveria ser, à prática, do que é, algo que ainda não está sendo extensamente realizado, mas que se espera que "pouco a pouco" possa ser concretizado.

Na lista de discussão, denominada Bibamigos (SILÊNCIO..., 2009), analisamos alguns recortes enfocando a maneira como o silêncio é discursivizado, construindo sentidos sobre a biblioteca escolar e as atividades nela realizadas, retomando ou desconstruindo os 
sentidos de restrição enunciados nos recortes anteriores. Chamou-nos a atenção, nesta lista, o tópico intitulado "Silêncio na biblioteca" (ANEXO 12), que gerou seis mensagens (uma questão inicial seguida de cinco respostas), publicadas entre os dias 6 e 9 de maio de 2009. Nelas, o silêncio é discursivizado de diferentes formas de acordo com as posições ocupadas pelos sujeitos. Criou-se um espaço de discussão descontraído, no qual se pede e dá sugestões e até se faz brincadeiras sobre a difícil tarefa de implantar o silêncio na biblioteca escolar. Consideramos que a Internet permitiu a emergência do discurso polêmico, ou seja, aquele em que há um equilíbrio entre polissemia e paráfrase, no qual "a polissemia é controlada uma vez que os interlocutores procuram direcionar, cada um por si, o referente do discurso" (ORLANDI, 2003a, p.29). Observamos, nos recortes da lista de discussão supracitada, um jogo entre o retorno de sentidos que normatizam a ordem e o imperativo do silêncio nesse espaço escolar, e a emergência de outros, nos quais vozes contrárias entremeiam-se produzindo outros efeitos de sentido, apontando um funcionamento discursivo diferente e marcando na língua as pegadas de instabilidade do sentido dominante.

Queremos realizar a Campanha do Silêncio em nossa biblioteca, sendo assim, aceito sugestões

Gostaria de saber quais os procedimentos adotados em relação ao barulho dentro da biblioteca, principalmente quando os alunos utilizam as salas de estudo em grupo para conversarem alto.

Periodicamente lançar campanha do silêncio (você pode estabelecer um período: por mês, bimensalmente, etc), com material informativo, panfletos nos murais, e confeccionar camisas para os funcionários com uma frase de conscientização. Você vai ver que não é muito caro.

Os avisos nas mesas tem que ser beeem pequenininhos...pois avisos de tamanho normal não o fazem ler...avisos pequenos despertam a curiosidade e com certeza todos lerão e ficarão cientes da regra. Caso façam barulho, estão fazendo de propósito.

Nos recortes acima, a biblioteca é discursivizada como um espaço que deve ser organizado e regido pelo silêncio, no qual não caberia a conversa, o diálogo, os sons dos alunos nem o movimento deles. Até mesmo quando se trata de estudo em grupo, atividade que indica a priori a presença de várias vozes, não há, assim, brechas por onde o silêncio possa escapar. Podemos observar como a memória sustenta esse discurso dominante sobre o silêncio na biblioteca, naturalizando os sentidos de ordem e silêncio como os únicos possíveis de serem enunciados, devendo ser exigidos e mantidos seja por meio de procedimentos, normas, regras, campanhas ou avisos. Tal funcionamento é dado ao modo de passos infalíveis de uma receita de bolo que só não dará certo, se os sujeitos-alunos não a seguirem, conforme 
pudemos ver no período "Caso façam barulho, estão fazendo de propósito". A institucionalização do silêncio é ainda assegurada pelo comentário transcrito abaixo, que pontua uma data a ser lembrada, comemorada e repetida.

\section{Falando em Silêncio... Hoje, dia 07/05 é comemorado o Dia do Silêncio}

Pelo acesso ao interdiscurso, sabemos que uma data comemorativa diz respeito a fatos históricos, eventos de caráter nacional ou de extensão mundial, nascimento de celebridades ou temas de muita relevância; nessa direção de análise, observamos que, nesse recorte, o sujeito singulariza não apenas o dia e mês de comemoração do silêncio, mas uma identificação com os efeitos de silenciamento na biblioteca escolar, marcando-o com cumplicidade.

É interessante observarmos também como os significantes que até aqui sustentaram sentidos de restrição- cortando as asas de dizer dos sujeitos-escolares, imprimindo a lei do silêncio obrigatório, interditando o diálogo e a emergência de comentários singulares e de descobertas dos leitores- podem ser deslocados, produzindo diferentes efeitos de sentido. Isto é possível, pois, como nos disse Pêcheux (1997, p. 160), o sentido não existe em si mesmo, visto que: "as palavras, expressões, proposições, etc., mudam de sentido segundo as posições sustentadas por aqueles que as empregam”. Sendo assim, nos recortes abaixo, flagramos marcas linguísticas ("regra", "conscientização" e os seus correlatos) que apontam um funcionamento discursivo de uma posição discordante à campanha do silêncio, delineando outros efeitos de sentido sobre a biblioteca escolar e indiciando, na ordem da língua, as nefastas consequências dessas ações coercitivas, já enraizadas nas práticas discursivas e cotidianas em bibliotecas instaladas dentro de escolas.

Para ser bem sincera com você eu acho que este tipo de regra ou norma para biblioteca afeta muito a aceitação dos alunos para com o espaço.

Talvez para amenizar um pouco o barulho você possa fazer um trabalho de conscientização com os alunos, juntamente com o corpo docente da instituição, mostrando-lhes que é possível interagir e se comunicar na biblioteca sem prejudicar as outras pessoas. É um trabalho difícil mais que terá resultados muito mais satisfatórios. Falo isso por experiência própria.

Temos que incentivar o uso da biblioteca e estas ações fazem com que a mesma se torne um ambiente chato sendo que é de fundamental importância que a biblioteca seja um espaço, além de conhecimento, de convivência e interação entre os usuários.

O sujeito aqui sustenta o seu dizer apoiado no que considera ser um ponto importante nessa lista de discussão, a "experiência própria". Em se tratando de um espaço interativo de sujeitos-bibliotecários, trabalhar e ser dessa área inscreve um efeito de verdade, antecipando e 
atribuindo sentidos de confiança a esse dizer. Notamos o indício da dificuldade de contestar a lei maior do silêncio, o que também produz uma antecipação e uma identificação com o sujeito-leitor, visto que no recorte acima temos que é possível trabalhar com "convivência e interação entre os usuários" e "interagir e se comunicar na biblioteca sem prejudicar as outras pessoas"; no entanto, isso não é fácil, ou melhor, é "um trabalho difícil mais que terá resultados muito mais satisfatórios". Observamos, então, uma fissura aberta por este dizer na campanha do silêncio como a promover a emergência de um furo, uma rachadura naquilo que se apresentava, pelo efeito ideológico, como único modo de dizer da/sobre a biblioteca escolar.

Marcamos que essa lista de discussão, a partir da interatividade propiciada pelas redes hipertextuais, configurou-se como um espaço discursivo heterogêneo, no qual sujeitos enunciam a partir de diferentes formações discursivas, entrelaçando-se a outros sujeitos e discursos, promovendo tanto a repetição de um dizer autorizado e legitimado pela instituição de leitura na escola, quanto desarranjando-o. Destacamos a presença de um já-dito, que retorna (res)significando sentidos acerca de como deve ser uma biblioteca, do silêncio, das práticas educativas, etc. A seguir, podemos observar a retomada da memória, dada pelo discurso político, instalando um efeito de denúncia do silêncio.

Eu e os alunos odiamos a turma do psiu (tenho 45 e trabalhei numa biblioteca escolar por 6 meses como estagiário). Isto não quer dizer que todos tem que aceitar a algazarra que os alunos podem fazer na biblioteca. se vc tiver espaço, divida em ala dos falantes e não falantes. ao invés da placa proibido conversar ou algo do gênero (que eles odeiam) coloque PERMITIDO FALAR NA ALA DOS FALANTES....mas aqui o povo não quer barulho...ou algo assim, ao invés de proibir, permita algo que os leve a uma conscientização ou eles odiarão a biblioteca cada vez mais. seja dos nossos... lute contra "as tia" do psiu e combata o que incomoda com política e inteligência e não com plaquinhas autoritárias e ações militaristas. desculpa se o tom foi sarcástico, é que eu sei o quanto os alunos odeiam o PSIU e tenho que falar por eles...

Os dizeres supracitados são enunciados por um sujeito que também ocupa uma posição contrária aos sentidos que foram cristalizados, pela ideologia dominante, sobre o silêncio na escola e na biblioteca. Nessa posição discursiva, sustenta-se um efeito de denúncia, dado pela retomada de sentidos circulantes no discurso político e também militar. O sujeito enuncia em nome de si mesmo e dos sujeitos-alunos, para os quais assume o papel de porta-voz, visto que não lhes é permitido manifestarem-se na biblioteca e sobre ela, o que podemos observar nas formulações: "eu e os alunos odiamos", “seja dos nossos" e “tenho que falar por eles". 
Assim, imbuído como que de um estandarte da liberdade, o sujeito faz circular sua voz de protesto atravessada pela memória e heterogeneidade, criando um efeito imaginário de uma luta contra ações coercitivas de imposição do silêncio (tal qual no período em que vigorou a ditadura militar no país), as quais ele nomeia de "autoritárias" e "militaristas", devendo assim, serem combatidas com armas não-violentas (a saber, política e inteligência), como indicam as marcas linguísticas "lute" e "combata", que, no imperativo, ganham os contornos de uma convocação, um alistamento e um chamamento à luta. Nesse discurso, é incessantemente marcada a repulsa por estas ações em prol do silêncio, dada pela repetição dos termos correlatos: "ódio", “odiamos”, “odiarão"; observamos que, da mesma forma, também há uma repetição dos significantes "as tia do psiu", “turma do psiu” e "psiu”, que representariam o alvo deste ódio. Consideramos que esse significante "psiu" instala um campo semântico de interdição na medida em que pertence a uma região de sentidos tida como não desejável, em que se remete tal campanha a sentidos de ódio, proibição, militarização e autoritarismo que já foram ditos e esquecidos em outros contextos e que agora retornam, pelo movimento da memória discursiva, ressignificados em relação ao silêncio na biblioteca escolar.

Para marcar seu posicionamento frente à questão do silêncio, esse sujeito lança mão da polissemia, instaurando, onde só havia sentidos parafrásticos relativos à institucionalização do silêncio (tanto favoráveis, quanto desfavoráveis), novos sentidos de interdição do mesmo, através do jogo entre os significantes "permitir" e "proibir", pelo qual se sugere que "ao invés de proibir, permita". Por fim, é importante marcarmos que, no discurso desse sujeito, também está presente o reconhecimento de que uma biblioteca na qual repousa um silêncio quase sepulcral não é desejável pelos alunos, o que contribuiria para agravar um descontentamento já existente, visto que eles podem odiar "ainda mais" a biblioteca escolar, reforçando os sentidos negativo já sustentados sobre esta instituição.

Além dos sentidos dados pelo discurso político, jurídico e militar, para apoiar ou rechaçar a campanha do silêncio, marcamos também um deslocamento de sentidos circulantes no campo semântico dos esportes e das brincadeiras infantis, como forma de representar o silêncio na biblioteca. No recorte abaixo, vemos que, entremeados a sentidos favoráveis, contrários e que incitam uma luta contra o silêncio, estão os dizeres que, em tom jocoso e quase conformista, aludem à (impossibilidade de) sua imposição, por meio de uma brincadeira infantil que tem esse objetivo, a da "vaca amarela", sendo assim, apesar de se posicionar favoravelmente ao silêncio, posto que os avisos que o exigem deveriam ser colocados nas bibliotecas, não se acredita na eficácia dessas ações e nem na possibilidade da 
total ausência de vozes nesse espaço. Temos aqui um funcionamento discursivo diferente, no qual o sujeito-aluno não é discursivizado como um perturbador da ordem, que o faz "de propósito" como em um dizer anterior, ou como vítima de políticas cerceadoras, mas como um "brincalhão", criando, através dos efeitos de brincadeira inerentes ao mundo infantil, outra região de sentidos.

Michelle faz a brincadeira da vaca amarela rssss... Desculpas pela brincadeira, mas já passe por isso, e sempre teve um ou outro brincalhão que ficava fazendo mais barulho que antes, acho que deve sim colocar avisos, mas pelo que sei instituições particulares não adianta muito tais avisos. Minha opinião.

Já nos nosso próximo recorte, observamos como os dizeres dados pelo sistema de punições usado nos esportes, como o futebol e o vôlei, tidos como normativos e necessários para o funcionamento das competições, retornam e ressignificam a necessidade de se controlar e impor limites ao ruído.

Mobilizar um funcionário e fornecê-lo cartões: verde, amarelo e vermelho. Quando alguém tiver fazendo barulho a pessoa chega e mostra o cartão amarelo, que adverte o usuário de forma mais sutil. $O$ cartão vermelho adverte o usuário que "passou dos limites". É uma forma que causa impacto e somente o usuário sabe do que se trata, sem constrangê-lo perante os outros. O cartão verde por sua vez é entregue ao usuário que fez silêncio, em forma de marcador de livro, com uma frase parabenizando-o pelo bom uso da biblioteca. Com certeza dissemina a boa ação entre os colegas. Esse último projeto não é meu, mas foi apresentado num encontro de bibliotecários. A Bibliotecária disse ter resolvido o problema no período de provas.

Por conseguinte, o sujeito-bibliotecário assumiria uma posição de "árbitro", dirigindo o "jogo" das atividades realizadas na biblioteca empreendido por "jogadores" que, ao cometerem uma infração, especialmente se ela "passar dos limites", devem ser advertidos. Cremos que, apesar de haver, na fala desse sujeito, uma preocupação com o nãoconstrangimento, a não-obrigatoriedade do silêncio e o reconhecimento de que este não precisa estar presente em todos os momentos e situações, como se pode observar nos enunciados seguintes, os sentidos dominantes “campeões” em seu discurso são os de restrição e colorem com tinta forte aquilo que já é dito e repetido sobre a lei do silêncio.

Concordo também com a transformação do espaço da biblioteca em discussões e debates de grupos. Gosto do ambiente movimentado, e geralmente não cobro silêncio quando não há alunos estudando. 
Mas já trabalhei numa biblioteca com grande fluxo de alunos (mais de 1.000 por dia) e lá tínhamos que fazer sempre campanhas de silêncio. O legal é que eu tinha o apoio e ajuda de toda a equipe.

Já fiz várias campanhas, mas listo para você algumas que realmente deram certo

Mas de qualquer forma seria bom oscilar entre períodos de silêncio (como por exemplo no período de provas) e uma certa liberação de conversa na biblioteca. Os usuários tem que ser impactados com o bom senso, e não fazerem silêncio obrigatoriamente. É importante criar uma idéia que explique o porquê. É minha opinião!

Marcamos a circulação de um efeito de veracidade e comprovação em um recorte anterior, no qual, o discurso do sujeito é atravessado pela voz de um outro ("A Bibliotecária disse") que conhece e tem experiência no assunto, podendo assim, dar conselhos e indicar ações a serem realizadas pelos demais. De forma semelhante, outros dizeres, agora não mais pela heterogeneidade, atestam esse efeito de confiabilidade no discurso como se pode observar nas marcas: “com certeza”, “pelo que sei”, “trabalhei numa biblioteca”, “já passei por isso", "já fiz", "realmente deram certo", etc. Notamos, em praticamente todos os recortes, o uso constante da primeira pessoa do singular ou plural, marcando ora o sujeitobibliotecário em particular (no caso o sujeito que enuncia) ou em geral (todos os bibliotecários). Formulações como "É minha opinião!”, “Minha opinião”, “Eu e os alunos odiamos" "concordo", "gosto", “falo" nos dão pistas disso. Tal uso, para um olhar desatento, parece ser natural, mas, para nós, significa outra forma de enunciar e construir sentidos sobre o silêncio e a biblioteca, que pode indicar uma tentativa de o sujeito marcar a sua responsabilidade pelo seu dizer, furtando-se de ocupar, por exemplo, o lugar de bibliotecário para tanto. Contudo, ao enunciar, o sujeito é afetado por discursos já-ditos e esquecidos no campo político, jurídico, esportivo, militar e, também, da Biblioteconomia; pensando ser a origem do seu dizer, o sujeito acredita estar "falando por si mesmo", no ciberespaço que carrega um emblema da liberdade total e propicia essa ilusão. É importante lembrarmos que, para assumir a responsabilidade pelo seu dizer, o sujeito precisa enunciar o novo, e não apenas uma paráfrase de sentidos há muito repetidos sobre a biblioteca e seu espaço.

Ressaltamos que a responsabilidade e posicionamento pelo que se diz, assim como a tentativa de conter a deriva, "amarrar" seu discurso à teia da memória, promovendo o rompimento com sentidos dominantes e possibilitando a emergência de dizeres polissêmicos com a circulação de outras vozes são condições para que haja autoria. Sugerimos que, nos recortes analisados, há indícios de autoria, visto que encontramos sentidos além do 
dominante, instalados a partir da retomada e deslocamento de sentidos circulantes em outros discursos; assim, marcamos a emergência de novas formas de significar o silêncio e a biblioteca, por meio de uma disputa entre vozes difusas em um discurso polêmico que é propiciado pela maleabilidade da rede eletrônica. Nesse espaço, imaginariamente, o sujeito poderia ser livre para enunciar à sua maneira e romper com o mesmo, seja mobilizando regiões de dizer já faladas na ordem da lei, da brincadeira infantil, dentre outras.

Posto isto, flagramos, no trânsito de mensagens que instalou um discurso polêmico sobre o silêncio na biblioteca, como os movimentos heterogêneos de sujeitos-navegadores são ainda mais dinâmicos nas listas de discussão, como a Bibamigos. A seguir, analisaremos mais alguns recortes dessa lista (AJUDA... 2009), publicados entre os dias 23 e 24 de dezembro de 2009 (ANEXO 13), observando os efeitos de sentidos que se entremeiam em uma rede de significações mais plurais sobre a biblioteca escolar e que foram enunciados a partir de uma indagação, que gerou duas respostas. Conheçamos o primeiro nó dessa rede:

Amigos, em março/ 2010 iniciarei o trabalho em uma biblioteca escolar e já
comecei a estudar mais sobre tema, as particularidades dessa instituição e
questões conceituais, pois a prática de catalogação, classificação eu já
tenho. Por isso, gostaria que vocês me falasem um pouco sobre as
bibliotecas escolares: o que vocês pensam sobre ela? Vocês conhecem boas
bibliotecas escolares? E o bibliotecário escolar, existe?

Destacamos que, através das indagações feitas, o sujeito instala um efeito de dúvida em relação à existência de "boas bibliotecas escolares" e do "bibliotecário escolar", posto que é necessário que alguém a confirme, ateste sua veracidade, desnaturalizando, assim, os dizeres inscritos em uma formação discursiva que insere a biblioteca em uma esfera idealizada, onde todas as bibliotecas seriam adequadas e implicariam a presença do bibliotecário. Tais formulações são indícios, também, de um interesse pela biblioteca, por conhecê-la, estudá-la, investigar seu conceito, indo além das questões técnicas. Esse posicionamento suscitou a emergência de outros, que também encontraram um espaço, nesta lista, para enunciar de uma maneira diferente, mais plural, sobre a biblioteca escolar, vejamos:

Vou te dar a minha impressão de criança que frequentou biblioteca escolar quanto este termo não era ainda disseminado. Meu interesse pelos livros começou justamente porquê uma professora, ainda no Jardim de Infância, expôs alguns livros muito atrativos, coloridos, e de tamanhos variados, em local de fácil acesso e sem burocracia para nós alunos, ainda aprendendo a ler. Esta experiência modificou a minha vida a ponto de eu e meus amigos ao longo da vida escolar procurarmos sempre pela biblioteca da escola, uma salinha um pouco suja e desarrumada, isto se deu até entrarmos no ensino médio. Traduzindo, como usuária apaixonada, identifiquei sempre primeiro, boa vontade, atenção e pouca burocracia. 
Por mais que a biblioteca seja farta de acervo, tenha tecnologia disponível, o que conta é o ser humano por trás 'do balcão'. Este é o fator que vai fazer o usuário voltar ou não.

Através dos sentidos que discursivizam seus primeiros contatos com os livros, sua “impressão" dos mesmos, o sujeito atribui importância à biblioteca e às ações dinamizadoras das obras, que as apresentem ao sujeito-leitor de forma criativa e sem restrições, levando a práticas interessantes e transformadoras. A partir dessa perspectiva mais ampla e aberta a outras possibilidades, acredita-se poder minimizar os problemas existentes nas bibliotecas, que funcionam, muitas vezes, de forma precária, como uma "salinha um pouco suja e desarrumada"; sendo assim, confere-se valor ao profissional que atua na biblioteca escolar, um importante papel que pode significar a sua estagnação ou dinamicidade. Concordamos com a importância atribuída a esse profissional, mas ressaltamos que é necessária, também, uma ação conjunta, que engloba a atuação política, docente, estudantil e, também familiar e social. Comumente as ações de sucesso em bibliotecas não dependem necessariamente de condições ideais, mas se houver a disponibilidade de maiores recursos, eles potencializarão os resultados alcançados. Observamos ainda que, muitas vezes, a falta de alguns elementos pode impedir que as ações sejam realizadas; assim sendo, não se pode deixar todas as atividades a cargo do profissional que trabalha na biblioteca escolar. Voltando à nossa análise, nós flagramos, em uma segunda resposta enviada à pergunta inicial, um embate entre o discurso dominante e aqueles que o furam, pelo qual se contrapõem os sentidos que apontam para os problemas das bibliotecas escolares e para práticas mais polissêmicas que as valorizam, como vemos a seguir:

Eu adoro o universo da biblioteca escolar. Se um dia puder me custear até trabalho em uma porque pagam muito mal (cerca de 1000 a 1300 contos...por oito horas de trampo...vich, só pra quem pode ter um salário destes depois de estudar 5 anos.

Podemos inferir que baixos salários estariam em consonância com os sentidos de desvalorização da biblioteca, e, nesse discurso, marcam a impossibilidade de atuar nela, apesar do interesse demonstrado. Outro recorte em que se instala esse litígio entre formações discursivas está transcrito a seguir:

Bom, se eu pudesse resumir diria que a biblioteca escolar é a casa da invenção, como diz o Título do Prof. Milanesi. Mas não pode desanimar porque a verdade é que os alunos não gostam de ler, ao menos a maioria. Com minhas invenções já vi muitos milagres acontecerem. tipo o aluno mais bagunceiro da escola ler algo que nunca leria antes... "Como educar seus pais' ou sobre a vida do rei Arthur. 
A biblioteca é discursivizada por esse sujeito como um lugar dinâmico, que precisa ser (re)inventado para que seja possível superar os problemas, como o da falta de gosto pela leitura. Através da persistência de práticas mais polissêmicas, alguns "milagres" podem ocorrer, marca que inscreve a memória discursiva e faz funcionar discursivamente o efeito de emergência de sentidos mais positivos acerca da biblioteca e de suas atividades, aproximandoas dos sujeitos leitores, que precisam ser seduzidos, "captados" na teia envolvente da biblioteca:

Eu inventava muito. Ficava, ao invés de polindo o acervo para ninguém, engenhando formas e formas de captar seguidores das boas letras. Era como planejar de que lado iria armar a teia de aranha para pegar minhas 'vítimas'. Colocava recados importantes pregados com desenhos engraçados no monitor dos computadores, eu sabia que ali eles iriam ler... até poesia liam assim. Espalhava pilhas de livros (os de capa dura e portanto, mais resistentes) pelo pátio para que eles tropeçassem na hora do recreio (assim perceberiam que existiam vida por trás do balcão da biblioteca...) Colava poesias no piso, perto do banco onde eles sentavam e cobria com contact (sabe como é, sentou ali, nada pra fazer...o que é isto aqui no chão?), mantinha minhas máscaras de gesso á mão para que eles brincassem com elas de teatro, usava uma máquina velha de slides para contar historias ou lendas clássicas e tem até filme de dança do caranguejo dentro da biblioteca... Indicava livros com títulos interessantes como 'tem uma lagartixa dentro do meu computador' ou 'como educar seus pais'

acho que sou tão fascinado pela biblioteca escolar que poderia escrever um livro que chamaria: 'As peripécias de um bibliotecário maluco para captar leitores ariscos em uma biblioteca escolar'. Sempre odiei o psiu, eles podiam trocar idéias e sempre o faziam dentro da biblioteca. A moderação era um pedido e não uma ordem. ao invés de 'proibido conversar' ou 'silêncio' a placa era: Permitido falar baixo.

Assim, através de uma variedade de atividades criativas e inusitadas ("peripécias”), que visam à aproximação com o sujeitos-leitores, estes poderiam deixar-se enredar na biblioteca, instigados pela curiosa e variada maneira de mediar as obras e os recursos disponíveis na mesma. Essas ações, implementadas com prazer e fascínio, seriam acompanhadas de uma prática que permite a circulação de outros discursos, que vão de encontro àqueles que fazem falar a burocratização e o cerceamento da biblioteca, bem como as atividades direcionadas apenas à manutenção do acervo e da ordem. Assim, apesar das dificuldades encontradas, poderiam emergir sentidos que discursivizam de uma forma bem diferente a biblioteca, próxima daquela considerada ideal.

A partir do que foi exposto neste capítulo, podemos considerar a Internet como um observatório de sentidos mais plurais, dados pelos confrontos entre diferentes formações discursivas que se interpenetram, entre sentidos e sujeitos em movimento constante e 
interação, propiciada pela volatilidade da rede e pela maleabilidade do discurso. Na próxima seção, faremos mais algumas considerações, retomando o percurso que trilhamos até aqui e encaminhando-nos para o seu fechamento, ainda que ilusório, pois os sentidos não se fecham jamais. 


\section{MOVIMENTOS FINAIS: EM BUSCA DE OUTRAS MARGENS}

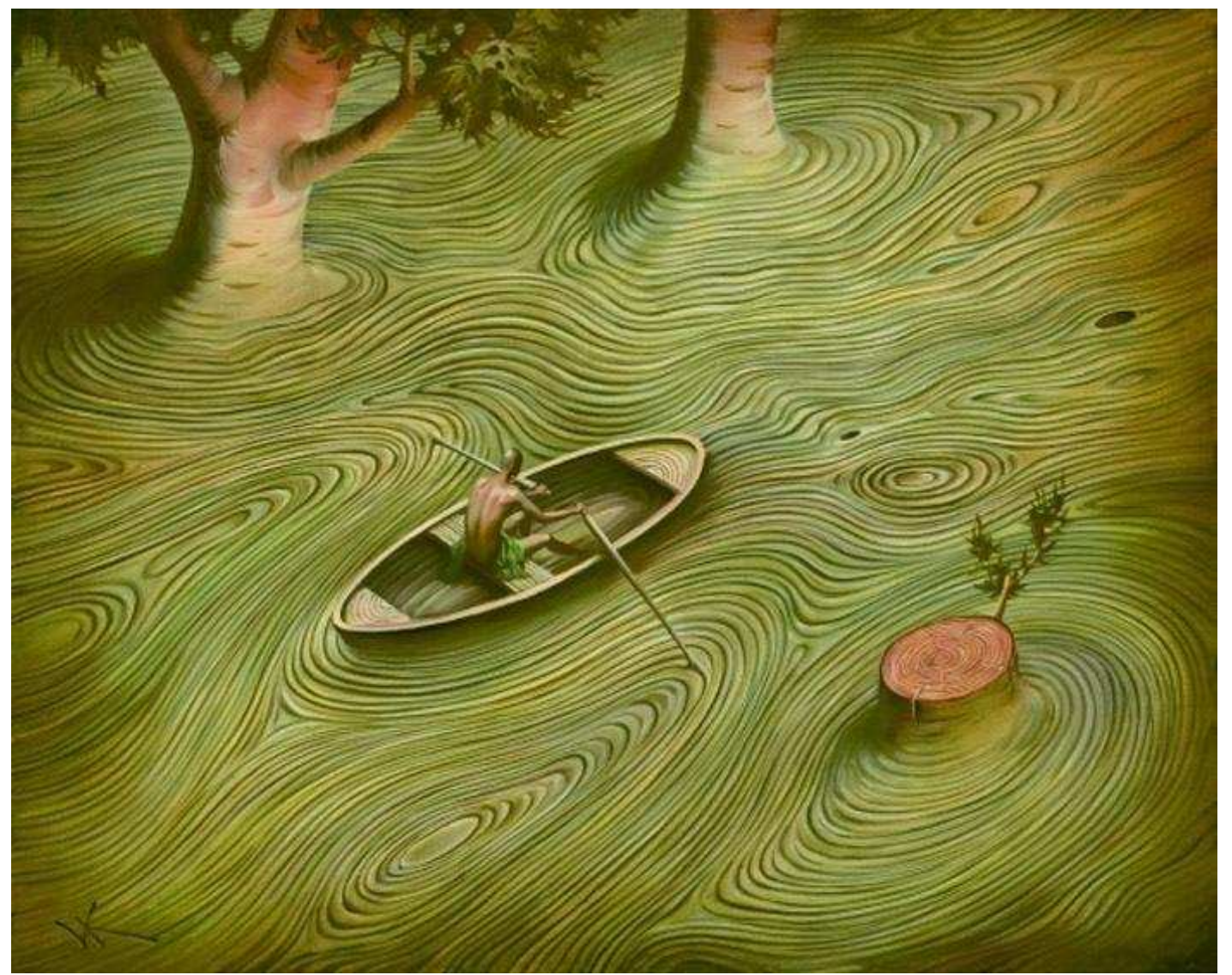

Figura 6. Current

As palavras são apenas pedras postas a atravessar a corrente de um rio, se estão ali é para que possamos chegar à outra margem, a outra margem é que importa. A não ser que esses tais rios não tenham duas margens, mas muitas, que cada pessoa que lê seja, ela, a sua própria margem, e que seja sua, e apenas sua, a margem a que terá de chegar. (SARAMAGO, 2000, p. 77) 
Chegamos ao fim do nosso percurso de navegação e é hora de recolhermos as velas e perpassarmos os objetivos da viagem e os portos em que paramos. Nosso desejo inicial, ao lançarmo-nos nas águas instáveis do ciberespaço, era analisar discursivamente os movimentos do sujeito e dos sentidos nas páginas eletrônicas sobre essa instituição, escutar a discursividade eletrônica, os movimentos de navegação dos sujeitos, observando se a rede eletrônica configura-se como o lugar da tão aclamada possibilidade de emergência do sujeito e de dizeres polissêmicos, que façam surgir sentidos além do dominante. A respeito do nosso trajeto de navegação, frisamos que, no primeiro porto em que paramos, inscrevemo-nos em uma posição de entremeio, buscando construir sentidos que nos possibilitassem seguir viagem; para tanto, discorremos sobre alguns conceitos fundamentais da Análise do Discurso, tais como, discurso, condições de produção, ideologia, sujeito, formação discursiva, ideológica e imaginária, memória e heterogeneidade. A partir desses pressupostos, analisamos três documentos oficiais do Conselho Regional de Biblioteca, que inscrevem a biblioteca escolar em uma formação discursiva dominante, atravessada pela heterogeneidade e por sentidos que ora sustentam, ora rompem com o já-lá.

Na etapa seguinte, adentramos um (ciber)espaço instável, múltiplo e movente, que nos levou a investigarmos desde as suas condições de produção e as (im)possibilidades de navegação até a maneira como é estruturado e (re)construído, a partir do movimento de sujeitos e sentidos que se constituem ao mesmo tempo, em suas redes. Ao retomarmos nossa hipótese inicial de que a rede eletrônica abriria espaço para a emergência de sentidos mais plurais acerca da biblioteca escolar, podemos afirmar, a partir das análises dispostas ao longo do trabalho, que esse ciberespaço heterogêneo e interativo faz falar também o plural, permite os furos nas regiões de sentido estabilizadas pelo retorno da memória, suscitando outras maneiras de enunciar sobre essa instituição, outras margens de sentido. Ainda nesse capítulo, apresentamos uma biblioteca escolar digital, tecendo algumas considerações sobre a sua particularidade, interatividade e os traços que fazem falar outras maneiras de produzir gestos de leitura e escrita, a partir da tecnologia hipertextual.

Em seguida, abordamos a biblioteca escolar, através de uma perspectiva múltipla, buscando tecer gestos de enleio entre a Análise do Discurso, a Educação e a Ciência da Informação, apresentar os sentidos circulantes em diferentes formações discursivas sobre a biblioteca, passeando por vários sentidos, a fim de investigarmos quais retornam, são silenciados ou, ainda, reconstruídos. A partir da investigação pela qual rastreamos os discursos sobre biblioteca escolar ao longo da história, pudemos perceber, nas análises, como os sentidos de restrição constituem um dizer cristalizado e que retorna nos discursos que, por 
não serem fechados, permitem que o novo promova uma mudança nessa rede de sentidos. Abordamos, também, algumas considerações sobre a leitura e pesquisa escolar que, por serem as atividades mais praticadas nas bibliotecas, tem grande importância para a construção de sentidos construído sobre elas. Por último, destacamos que, nesse capítulo, analisamos alguns sites de escolas brasileiras, a fim de investigarmos se/como as bibliotecas são neles discursivizadas e apresentamos, também, algumas considerações sobre as bibliotecas escolares digitais, quais seriam as suas contribuições para novas práticas educativas, indagando se é possível sua disseminação no contexto educacional brasileiro.

Finalmente, procuramos investigar as representações imaginárias da biblioteca escolar, em um corpus formado por recortes de blogs e listas de discussão das áreas de Biblioteconomia/Ciência da Informação. A partir deles, deparamo-nos com sentidos que se alinham à formação discursiva dominante, ao enunciarem sobre a precariedade da biblioteca escolar, marcada pelo silêncio, castigo e inércia em seu espaço, e pela rigidez do seu profissional. Além desses sentidos, aqueles referentes à idealização da biblioteca e de normatização de como ela deve ser também são recorrentes, legitimados a partir da retomada de uma série de documentos oficiais internacionais que, supostamente, atribuiriam um efeito de veracidade. Pelas marcas de heterogeneidade, flagramos o embate entre essas formações discursivas diferentes que, como procuramos sustentar nesse trabalho, não possuem fronteiras rígidas, já que os sentidos não são fixos, mas estão sempre a deslocar-se, migrando para outras margens, novos percursos, abrindo-se, como pudemos observar ao longo das análises, a sentidos outros que as desestabilizem, pois a navegação nunca se dá por terminada, é reiniciada em cada tomada da palavra, em cada novo porto de passagem. Diante dessa impossibilidade de parada permanente, impõem-se os efeitos de fim, pelos quais, chegando ao destino planejado, consideramos ilusoriamente ser este o porto final, até que outras rotas nos motivem a içar novamente as velas, a conduzir nossa embarcação pelas águas turvas do sentido, do ciberespaço e da biblioteca escolar. 


\section{REFERÊNCIAS}

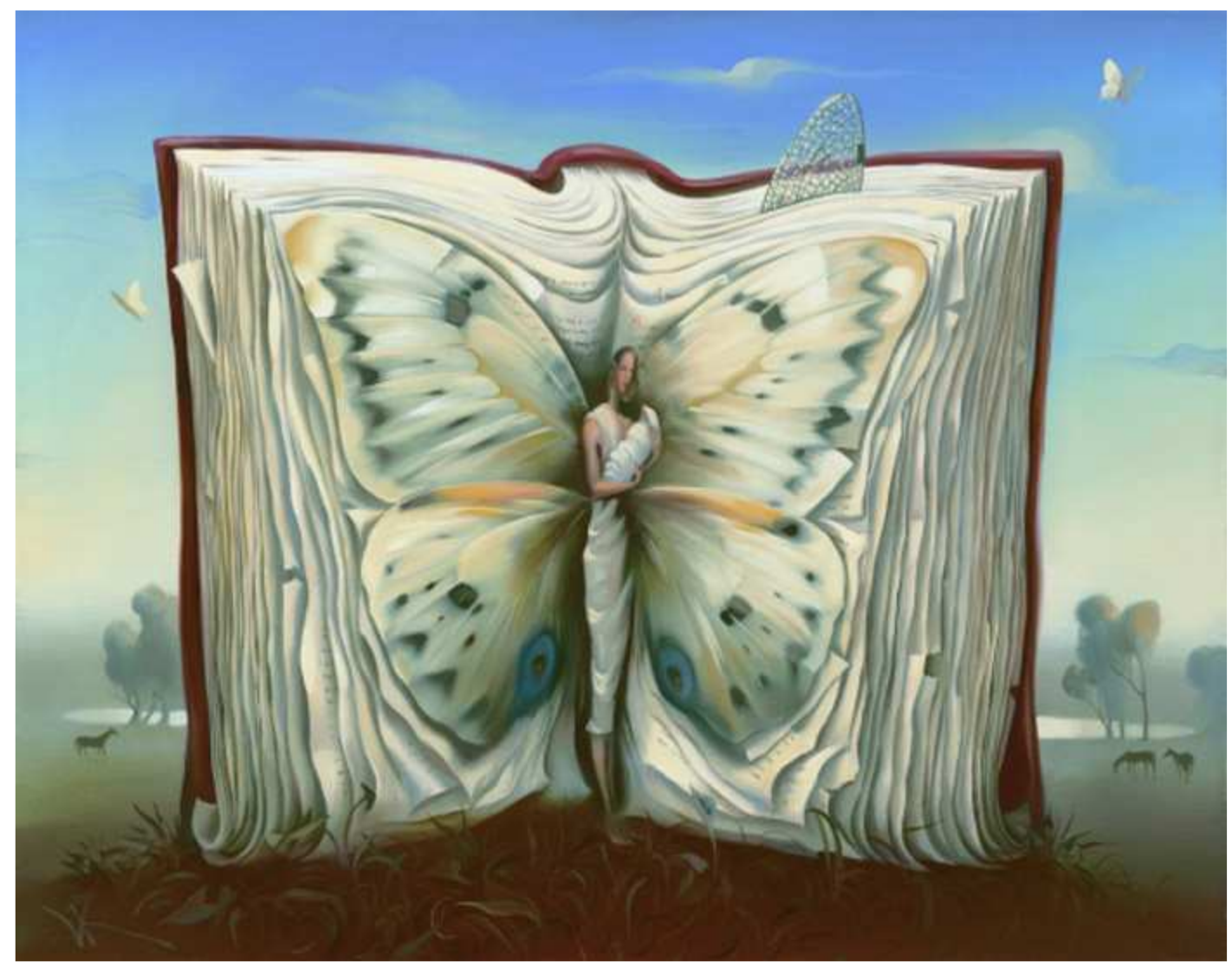

Figura 7. Book of books

"O mais difícil, mesmo, é a arte de desler" (QUINTANA, 2006, p. 165) 
AFINAL: empresta ou não empresta? 2009. Disponível em: <http://biblio20.wordpress.com/ 2009/09/19/afinal-empresta-ou-nao-empresta/>. Acesso em: 10 dez. 2009.

AGUSTINI, Carmen Lucia Hernandes. (N)as dobraduras do dizer e (n)o não-um do sentido e do sujeito: um efeito da presença do interdiscurso no intradiscurso. In: SEMINÁRIO DE ESTUDOS EM ANÁLISE DO DISCURSO, 2., 2005, Porto Alegre. Anais eletrônicos... Porto Alegre: Universidade Federal do Rio Grande do Sul, 2005. Disponível em: <http://www.discurso.ufrgs.br/sead2/doc/interdiscurso/carmenagustini.pdf >. Acesso em: 4 jun. 2010.

AJUDA-biblioteca escolar. 2009. Disponível em: < http://br.groups.yahoo.com/group/ bibamigos/message/27074>. Acesso em: 26 dez. 2009.

ALMEIDA JÚNIOR, Oswaldo Francisco de. Pesquisa escolar: entre o modelo educacional e a liberdade da pesquisa. In: . (Orgs.). Fazeres cotidianos na biblioteca escolar. São

Paulo: Polis, 2006.

ALMEIDA JÚNIOR, Oswaldo Francisco de; BORTOLIN, Sueli. Bibliotecário: um essencial mediador de leitura. In: SOUZA, Renata Junqueira de (Org.). Biblioteca escolar e práticas educativas. Campinas: Mercado de Letras, 2009. p. 205-218.

AMARAL, Sérgio Ferreira do; GARBIN, Mônica Cristina. Construção de um ambiente educacional interativo na Internet: a Biblioteca Escolar Digital. Revista Iberoamericana de Educação, n.45-46, 10 abr. 2008. Disponível em: <http://www.rieoei.org/2378.htm >. Acesso em: 8 set. 2009.

AMATO, Mirian; GARCIA, Neise Aparecida Rodrigues. A biblioteca na escola. In: GARCIA, Edson Gabriel (Org.). Biblioteca escolar: estrutura e funcionamento. 2.ed. São Paulo: Loyola, 1998.

ANTUNES, Walda de Andrade. Biblioteca escolar no Brasil: reconceituação e busca de sua identidade a partir de atores do processo ensino-aprendizagem. 1998. Tese (Doutorado)Faculdade de Educação, Universidade de São Paulo, Ribeirão Preto, 1998.

APRESENTANDO a biblioteca escolar. 2009. Disponível em: <http://bibliotequiceseafins. blogspot.com/2009/11/apresentando-biblioteca-escolar.html>. Acesso em: 5 dez. 2009.

ARENA, Dagoberto Buim. Leitura no espaço da biblioteca escolar. In: SOUZA, Renata Junqueira de (Org.). Biblioteca escolar e práticas educativas. Campinas: Mercado de Letras, 2009. p. 157-185.

AUTHIER-REVUZ, Jacqueline. Heterogeneidade(s) enunciativa(s). Cadernos de Estudos Linguísticos, n.19, 1990.

- Heterogeneidade mostrada e heterogeneidade constitutiva: elementos para uma abordagem do outro no discurso. In: Entre a transparência e a opacidade: um estudo enunciativo do sentido. Porto Alegre: EDPUCRS, 2004. p. 11-80. 
BAJOUR, Cecília. Quando a biblioteca é um assunto de escola. Pensar el libro, n. 5, jan. 2007. Disponível em: <http://www.cerlalc.org/revista_enero/articulo03_p.htm>. Acesso em: 10 dez. 2009.

BARÓ, Mónica; MAÑA, Teresa; VELLOSILLO, Inmaculada. Bibliotecas escolares, ¿para qué? Madrid: Anaya, 2001.

BARROS, Manuel. Livro sobre Nada. Rio de Janeiro: Record, 1996.

BARTHES, Roland. S/Z. Rio de Janeiro: Nova Fronteira, 1992.

BAUMAN, Zygmunt. Globalização: as consequências humanas. Rio de Janeiro: Jorge Zahar, 1999.

Modernidade líquida. Rio de Janeiro: Jorge Zahar, 2001.

BEAUCHAMP, Jeanete; SILVA, Jane Cristina da. Bibliotecas escolares: a experiência brasileira. Pensar el libro, n.5, jan. 2007, Disponível em: <http://www.cerlalc.org/ revista_enero/articulo04_p.htm>. Acesso em: 10 ago. 2009.

BIBLIOTECA escolar: algumas considerações. 2009. Disponível em: <http://biblio20. wordpress.com/2009/07/07/biblioteca-escolar-algumas-consideracoes/> Acesso em: 20 nov. 2009.

BIBLIOTECA escolar (desrespeito ao espaço). 2008. Disponível em: <http://www.grupos. com.br/group/bibliotecarios/Messages.html?action=message $\&$ id=1224195744308126\&year= $08 \&$ month $=10 \& / \% 5$ BBibliotecarios $\% 5 \mathrm{D} \% 20 \mathrm{BIBLIOTECA} \% 20 \mathrm{ESCOLAR} \% 20 \% 28 \mathrm{desresp}$ eito\%20ao\%20espa\%E7o\%29>. Acesso em: 10 jun. 2009.

BICHERI, Ana Lúcia Antunes de Oliveira; ELLWEIN, Selma Alice Ferreira. Pesquisa escolar na Internet. In: Paulo: Polis, 2006. (Orgs.). Fazeres cotidianos na biblioteca escolar. São

BLATTMANN, Úrsula; FRAGOSO, Graça Maria. O zapear a informação em bibliotecas e na Internet. Belo Horizonte: Autentica, 2003.

BOMBINI, Gustavo. Biblioteca escolar e comunidade: uma relação anotações sobre uma relação sem experiência. Pensar el libro, n. 5, jan. 2007. Disponível em:

<http://www.cerlalc.org/revista_enero/pdf/02_p.pdf>. Acesso em: 10 dez. 2009.

BORGES, Jorge Luis. Obras completas. v. 2. Buenos Aires: Emecé, 1989.

A biblioteca de Babel. In:

Ficções. 3.ed. São Paulo: Globo, 2001.

BRASIL. Lei $n^{\circ} 12244$, de 24 de maio de 2010. Dispõe sobre a universalização das bibliotecas nas instituições de ensino do País. Diário Oficial da União. Brasília, 25 maio 2010. Disponível em: < http://www.jusbrasil.com.br/diarios/5259000/dou-secao-1-25-052010-pg-3>. Acesso em: 17 out. 2009. 
BRASIL. Ministério da Educação. Instituto Nacional de Estudos e Pesquisas Educacionais. Resultados do Censo da Educação Básica 2009. 2009. Disponível em: $<$ http://www.inep.gov.br/download/censo/2009/TEXTO_DIVULGACAO_EDUCACENSO_ 20093.pdf>. Acesso em: $10 \mathrm{dez} .2009$.

BRASIL. Ministério da Educação. Programa Nacional Biblioteca da Escola. Portal do MEC, c2009. Disponível em: <http://portal.mec.gov.br/index.php?option=com_content $\&$ view=article\&id=12368\&Itemid=574>. Acesso em: $10 \mathrm{dez} .2009$.

BRASIL. Ministério da Educação e do Desporto. Secretaria de Educação Fundamental. Parâmetros Curriculares Nacionais: Língua Portuguesa. Brasília: [S.1.], 1997.

BRECHT, Bertolt. Poemas 1913 - 1956. Seleção e tradução de Paulo César de Souza. São Paulo: Editora 34, 2000.

BUCCI, Eugênio. Inovações na imprensa em tempos de revoluções tecnológicas.

Observatório da imprensa, n. 437, 28 maio. 2008. Disponível em:

< http://www.observatoriodaimprensa.com.br/artigos.asp?cod=487IMQ004 >. Acesso em: 10 jul. 2009.

CAMPELLO, Bernadete Santos. A biblioteca escolar: temas para uma prática pedagógica. Belo Horizonte: Autêntica 2002.

A função educativa da biblioteca escolar no Brasil: perspectivas para seu aperfeiçoamento. In: ENCONTRO NACIONAL DE PESQUISA EM CIÊNCIA DA INFORMAÇÃO, 5., 2003, Belo Horizonte. Anais... Belo Horizonte: Escola de Ciência da Informação da UFMG, 2003. CD-ROM. Disponível em: <http://www.eci.ufmg.br/ gebe/? download=301.pdf $>$. Acesso em: 19 set. 2007.

CAMPOS, Cláudia de Arruda; BEZERRA, Maria de Lourdes Leandro. Bibliotecas escolares: um espaço estratégico. In: GARCIA, Edson Gabriel (Org.). Biblioteca escolar: estrutura e funcionamento. 2.ed. São Paulo: Loyola, 1998.

CARTA de Brasília do Sistema Conselho Federal e Regionais de Biblioteconomia em Defesa da Biblioteca Escolar. 2007. Disponível em: <http://www.grupos.com.br/group/bibliotecarios/ Messages.html ?action $=$ message $\&$ id $=1181658059125407 \&$ year $=07 \&$ month $=6 \& / \% 5$ BBibliote carios\%5D\%20CARTA\%20DE\%20BRASILIA\%20EM\%20DEFESA\%20DA\%20BIBLIOT ECA\%20ESCOLAR>. Acesso em: 12 dez. 2009

CASTELLANOS PFEIFFER, Cláudia. O lugar do conhecimento na escola: alunos e professores em busca de autorização. Série Escritos, Campinas, n.7, p.9-20, 2002.

CASTELLS, Manuel. A galáxia da Internet: reflexões sobre a Internet, os negócios e a sociedade. Rio de Janeiro: Jorge Zahar Editor, 2003a.

A sociedade em rede. 7 ed. São Paulo: Paz e Terra, 2003b. (A era da informação:

economia, sociedade e cultura, v.1). 
CASTRO, César Augusto. Ensino e biblioteca: diálogo possível. Transinformação, Campinas, v. 15, n. 1, p. 63-72, jan./abr. 2003. Disponível em: <http://revistas.puccampinas.edu.br/transinfo/viewissue.php?id=2>. Acesso em: 14 out. 2009.

CÉBRIAN, Juan Luis. A rede: como nossas vidas serão transformadas pelos novos meios de comunicação. 2 ed. São Paulo: Summus, 1999.

CHARTIER, Roger. A ordem dos livros: leitores, autores e bibliotecas na Europa entre os séculos XIV e XVIII. 2.ed. Brasília: Editora Universidade de Brasília, 1999.

Os desafios da escrita. Tradução de Fúlvia M. L. Moretto. São Paulo: Editora UNESP, 2002.

COMITÊ GESTOR DA INTERNET NO BRASIL. TIC Domicílios. In: Pesquisa sobre o uso das tecnologias da informação e da comunicação 2008. São Paulo, 2009. Disponível em: <http://www.cetic.br/tic/2008/index.htm>. Acesso em 2 ago. 2009.

CONSELHO de Altos Estudos prepara pesquisa sobre crimes na rede mundial. Jornal da Câmara. Brasília, n. 2312, 24 ago. 2009. Disponível em: <http://portalimprensa.uol. com.br/portal/ultimas_noticias/2009/08/21/imprensa30276.shtml>. Acesso em: 24 ago. 2009.

CONSELHO FEDERAL DE BIBLIOTECONOMIA. Exposição Biblioteca: Tudo começa aqui. 2009. Disponível em: <http://www.cfb.org.br/admin/imagens/cartaz.pdf>. Acesso em: 10 out. 2009.

CORACINI, Maria José R Faria. A redação no livro didático e na sala de aula: criatividade e avaliação. In: CORACINI, Maria José Rodrigues Faria (org). Interpretação, autoria e legitimação do livro didático: língua materna e língua estrangeira. Campinas: Pontes, 1999.

CORALINA, Cora. Vintém de cobre: meias confissões de Aninha. Goiânia: UFG, 1987.

CUEVAS CERVERÓ, Aurora. La biblioteca escolar como centro de recursos para el aprendizaje (CRA). In: Lectura, alfabetización en información y biblioteca escolar. Gijón: Trea, 2007, p.163-188.

DESESPERO pairando pelos ares fungóginos. 2008. Acesso em: $<$ http://diriodeumabiblioteca escolar.blogspot.com/2008/03/desespero-pairando-pelos-ares-fongginos.html >. Acesso em: 13 set. 2009.

DIAS, Cristiane Pereira. A discursividade da rede (de sentidos): a sala de bate-papo HIV . 2004. Tese (Doutorado)- Universidade Estadual de Campinas, Campinas, 2004.

Arquivos digitais: da des-ordem narrativa à rede de sentidos. In: GUIMARÃES, Eduardo; PAULA, Miriam Rose Brum de. Sentido e memória. Campinas: Pontes, 2005, p.41-56.

ELLWEIN, Selma Alice Ferreira. Pesquisa escolar e enfadonho exercício de cópia: como separar o trigo do joio? In: (Orgs.). Fazeres cotidianos na biblioteca escolar. São Paulo: Polis, 2006. 
ELY, Neiva Helena. Dimensões da biblioteca escolar no ensino fundamental. Revista ACB, Santa Catarina, v.8, n.1, p.46-53, 2003. Disponível em: <http://revista.acbsc.org.br/index. $\mathrm{php} / \mathrm{racb} / \mathrm{article} / \mathrm{view} / 405 / 510>$. Acesso em: $10 \mathrm{fev} .2009$.

ESCOLAS deveriam ter biblioteca na grade curricular. 2009. Disponível em:

< http://bibliotequiceseafins.blogspot.com/2009/12/escolas-deveriam-ter-biblioteca-na.html>. Acesso em: 15 dez. 2009.

FABRICANTES de PCs já instalam filtro de Internet. Observatório da imprensa, n.544, 18 ago. 2009. Disponível em: <http://www.observatoriodaimprensa.com.br/ artigos.asp? cod=544MON017>. Acesso em: 22 ago. 2009.

FEATHERSTONE, Mike. Cultura de consumo e pós-modernismo. Tradução de Júlio Assis Simões. São Paulo: Studio Nobel, 1995.

FERRAREZI, Ludmila. O imaginário sobre a biblioteca escolar: sentidos em discurso. 2007. 106 p. Trabalho de Conclusão de Curso. (Graduação em Ciências da Informação e da Documentação) - Faculdade de Filosofia Ciências e Letras de Ribeirão Preto, Universidade de São Paulo, Ribeirão Preto, 2007.

FERRAREZI, Ludmila; ROMÃO, Lucília Maria Sousa. Discurso jornalístico: efeitos de didatização da realidade. Observatório da imprensa, ano 12, n.382, 2006. Disponível em: $<$ http://www.observatoriodaimprensa.com.br/artigos.asp?cod=382DAC005>. Acesso em: 10 dez. 2009.

Morte 'anunciada': sentidos de memória e heterogeneidade no discurso jornalístico. Signótica, Goiânia, v. 19, n.2, p. 255-276, jul./dez. 2007.

. Leitura, escola e biblioteca na perspectiva discursiva. In: ROMÃO, Lucília Maria Sousa (Org.). Sentidos da biblioteca escolar. São Carlos: Gráfica e Editora Compacta, 2008a. p. 127-146.

O dizer dos documentos oficias: a normatização como efeito de sentidos sobre a biblioteca escolar. ACB, Florianópolis, v.13, n.2, p.323-346, jul./dez., 2008b. Disponível em: <http://revista.acbsc.org.br/index.php/racb/article/viewFile/536/666>.Acesso em: 10 ago. 2009.

FERREIRA, Eliane Aparecida Galvão Ribeiro. A leitura dialógica como elemento de articulação no interior de uma biblioteca vivida. In: SOUZA, Renata Junqueira de (Org.). Biblioteca escolar e práticas educativas. Campinas: Mercado de Letras, 2009.

FERREIRA, Maria Cristina Leandro. Da ambiguidade ao equívoco: a resistência da língua nos limites da sintaxe e do discurso. Porto Alegre: Editora da Universidade/UFRGS, 2000.

Nas trilhas do discurso: a propósito de leitura, sentido e interpretação. In:

ORLANDI, Eni. (Org.). A leitura e os leitores. 2 ed. Campinas: Pontes, 2003.

FOUCAULT, Michel. A ordem do discurso. 12. ed. São Paulo: Edições Loyola, 2005. 
FRAGOSO, Graça Maria. Biblioteca na escola. ACB, v. 7, n. 1, 2002. Disponível em: <http://revista.acbsc.org.br/index.php/racb/article/view/380/461>. Acesso em: 10 jul. 2009.

. Biblioteca na escola- uma relação a ser construída. ACB, v.10, n.2, p. 169-173, jan./dez., 2005. Disponível em: <http://dici.ibict.br/archive/00000837/01/R[1].ACB-2006129.pdf>. Acesso em: 21 ago. 2009.

FREIRE, Paulo. A importância do ato de ler: em três artigos que se completam. São Paulo: Cortez, 1989.

FUENTES ROMERO, Juan José. La biblioteca escolar. Madrid: Arco/Libros, 2006.

FURTADO, Cássia. A biblioteca escolar brasileira no sistema educacional da sociedade da informação. In: SEMINÁRIO BIBLIOTECA ESCOLAR: ESPAÇO DE AÇÃO

PEDAGÓGICA, 3., 2004, Belo Horizonte. Anais eletrônicos... Belo Horizonte: Escola de Biblioteconomia da Universidade Federal de Minas Gerais, Associação de Bibliotecários de Minas Gerais, 2004. Disponível em: <http://www.eci.ufmg.br/gebe/? Semin\%E1rios: III_Semin\%E1rio_Biblioteca_Escolar>.Acesso em: 10 abr. 2009.

GALEANO, Eduardo. Las palavras andantes. Coyoacán, México: Siglo Veintiuno, 1993.

GARCEZ, Eliane Fioravante. ACB, v.14, n.1, p.9-26, jan./jun., 2009. Disponível em: <revista.acbsc.org.br/index.php/racb/article/download/653/721>. Acesso em: 10 ago. 2009.

GINZBURG, Carlo. Sinais: Raízes de um Paradigma Indiciário. In: Mitos, Emblemas, Sinais: Morfologia e História. São Paulo: Companhia das Letras, 1980, p. 143 179.

GONZÁLEZ-SERNA, José Maria. De la biblioteca escolar a la biblioteca escolar virtual. Red digital: Revista de Tecnologías de la Información y Comunicación Educativas, n. 3, 2002. Disponível em: < http://dialnet.unirioja.es/servlet/articulo?codigo=1232689>. Acesso em: 17 nov. 2009.

GOOGLE recria página chinesa e volta a aceitar censura. 2010. Disponível em: $<$ http://tecnologia.terra.com.br/noticias/0,,OI4531238-EI12884,00-Google+recria+pagina+ chinesa+e+volta+a+aceitar+censura.html >. Acesso em: 29 jun.2010.

GREGOLIN, Maria do Rosário. Foucault e Pêcheux na análise do discurso: diálogos e duelos. São Carlos: Claraluz, 2004.

GUIMARÃES, Eduardo. Semântica do acontecimento: um estudo enunciativo da designação. 2.ed. Campinas: Pontes, 2005.

GUINZELIM, Cyntia Guizelin; GIROTTO, Simões; SOUZA, Renata Junqueira de. A hora do conto na biblioteca escolar:o diálogo entre a leitura literária e outras linguagens.In: SOUZA, Renata Junqueira de (Org.). Biblioteca escolar e práticas educativas. Campinas: Mercado de Letras, 2009. p.19-47. 
HILLESHEIM, Araci Isaltina de Andrade; FACHIN, Gleisy Regina Bóries. Biblioteca escolar e a leitura, ACB, v. 8, n.1, p. 35- 45, 2003. Disponível em:

<http://revista.acbsc.org.br/index.php/racb/article/view/404/507>. Acesso em: 10 jan. 2009.

INSTITUTO PAULO MONTENEGRO. Indicador de alfabetismo funcional. São Paulo, 2009. Disponível em: <http://www.ipm.org.br/ipmb_pagina.php?mpg=4.02.01. 00.00\&ver= por>. Acesso em: 10 jul. 2009.

INSTITUTO PRÓ-LIVRO. Retratos de leitura no Brasil. 2008. Disponível em: < http://www.prolivro.org.br/ipl/publier4.0/dados/anexos/48.pdf>. Acesso em: 10 ago. 2009.

INTERNATIONAL ASSOCIATION OF SCHOOL LIBRARIANSHIP. Declaração Política da IASL sobre Bibliotecas escolares. 1993. Disponível em: <http://www.oei.es/pdfs/ rbe5.pdf>. Acesso em: 10 jul. 2009.

INTERNATIONAL FEDERATION OF LIBRARY ASSOCIATION AND INSTITUTIONS. Manifesto IFLA/UNESCO para biblioteca escolar. Tradução de Neusa Dias de Macedo. São Paulo: [s.n.], 1999. Disponível em: <http://www.ifla.org/VII/s11/pubs/portuguesebrazil.pdf> Acesso em: 20 jun. 2009.

JAMESON, Fredric. A virada cultural: reflexões sobre o pós-moderno. Tradução de Carolina Araújo. Rio de Janeiro: Civilização Brasileira, 2006.

KUHLTHAU, Carol. Como usar a biblioteca na escola: um programa de atividades para o ensino fundamental. 2.ed. Belo Horizonte: Autêntica, 2004.

LEÃO, Lúcia. Interlab: labirintos do pensamento contemporâneo. São Paulo: Editora Iluminuras, 2002.

As derivas e os mapas. In: LEÃO, Lúcia (Org.). Derivas: cartografias do ciberespaço. São Paulo: Annablume, 2004.

O labirinto da hipermídia: arquitetura e navegação no ciberespaço. 3.ed. São Paulo: Editora Iluminuras, 2005.

LEMOS, André. Cibercultura e mobilidade: a era da conexão. In: LEÃO, Lúcia (Org.). Derivas: cartografias do ciberespaço. São Paulo: Annablume, 2004.

Cibercultura, tecnologia e vida social na cultura contemporânea. 3 ed. Porto Alegre: Sulina, 2007.

LÉVY, Pierre. O que é virtual? Tradução de Paulo Neves. São Paulo: Editora 34, 1996.

A inteligência coletiva: por uma antropologia do ciberespaço. Tradução de Luiz Paulo Rouanet. Edições Loyola: São Paulo, 1998.

Cibercultura. Tradução de Carlos Irineu da Costa. São Paulo: Editora 34, 1999.

LISPECTOR, Clarice. Os desastres de Sofia. In: A legião estrangeira. 10 ed. São Paulo: Siciliano, 1992. 
LOPES, Yara Brandão Boesel. Organização e funcionamento de uma sala de leitura. In: GARCIA, Edson Gabriel (Org.). Biblioteca escolar: estrutura e funcionamento. 2.ed. São Paulo: Loyola, 1998.

LYOTARD, Jean-François. A condição pós-moderna. Tradução de Ricardo Correa Barbosa. 8. Ed. Rio de Janeiro: José Olympio, 2004.

MALDIDIER, Denise. A inquietação do discurso: (re)ler Michel Pêcheux hoje. Campinas: Pontes, 2003.

MANGUEL, Alberto. A biblioteca à noite. São Paulo: Companhia das Letras, 2006.

MANIFESTO em Defesa da Biblioteca. Bob News CRB-8, n.5, jun. 2009. p.4-5. Disponível em: <http://repositorio.cfb.org.br/bitstream/123456789/265/1/BOBNEWS_Vol1_Numero5 _mar2009.pdf >. Acesso em: 10 out. 2009.

MAROTO, Lúcia Helena. Biblioteca escolar, eis a questão!: do espaço do castigo ao centro do fazer educativo. Belo Horizonte: Autêntica, 2009.

MARTINS, Elizandra; BORTOLIN, Sueli. O bibliotecário escolar 'afinando' o foco na leitura. In: (Orgs.). Fazeres cotidianos na biblioteca escolar. São Paulo: Polis, 2006.

MARTINS, Marília. Políticos na Grã-Bretanha e na Alemanha querem censurar Internet. Diário de Nova York- O Globo. 21 jun. 2009. Disponível em: <http://oglobo.globo. $\mathrm{com} / \mathrm{blogs} /$ ny/post.asp?t=politicos-na-gra-bretanha-na-alemanha-querem-censurarInternet\&cod_post=197649 >. Acesso em: 22 ago. 2009.

MARX, Karl; ENGELS, Friedrich. Manifesto do Partido Comunista. Petrópolis: Vozes, 1988.

MARZAL, Miguel Angel; CUEVAS CERVERÓ, Aurora. Biblioteca escolar para la sociedad del conocimiento en España. Ciência da informação, Brasília, v. 36, n. 1, 2007. Disponível em: <http://revista.ibict.br/ciinf/index.php/ciinf/article/view/909/706>. Acesso em: 12 set. 2009.

MEIRELES, Cecília. Romance LIII ou Das palavras aéreas. In: Rio de Janeiro: Civilização Brasileira, 1979. Poesias Completas. Mar absoluto; Retrato Natural. Rio de Janeiro: Nova Fronteira, 1983. Problemas da literatura infantil. 3 ed. Rio de Janeiro: Nova Fronteira, 1984.

MELO, Cristina Teixeira Vieira de. A análise do discurso em contraponto à noção de acessibilidade ilimitada da Internet. In: MARCUSCHI, Luiz Antônio; XAVIER, Antônio Carlos (Orgs.). Hipertexto e gêneros digitais. 2.ed. Rio de Janeiro: Editora Lucerna, 2005.

MILANESI, Luís. Biblioteca. Cotia, SP: Ateliê Editorial, 2002 
MINHA nova missão na biblioteca escolar. 2008a. Disponível em: <http://biblio20. wordpress.com/2008/11/06/minha-nova-missao-na-biblioteca-escolar/>.Acesso em: 16 out. 2009.

MINHA primeira 'Hora do Conto'. 2008b. Disponível em:

$<$ http://diriodeumabibliotecaescolar.blogspot.com/2008/03/minha-primeira-hora-doconto.html>. Acesso em: 24 nov. 2009.

MITTMANN, Solange. Heterogeneidade e função tradutor. Cadernos de tradução, Florianópolis, v.1, n.4, 1999. p. 221-237. Disponível em: <http://www.periodicos.ufsc.br/ index.php/traducao/article/viewFile/5533/6575>. Acesso em: 24 fev. 2010.

Redes e ressignificações no ciberespaço. In: ROMÃO, Lucília Maria Sousa; GASPAR, Nádea Regina. (Orgs). Discurso midiático: sentidos de memória e arquivo. São Carlos: Pedro \& João Editores, 2008, p. 113- 130.

MUSSALIM, Fernanda. Análise do Discurso. In: MUSSALIM, Fernanda; BENTES, Anna Christina (Orgs.). Introdução à Linguística: Domínios e Fronteiras. São Paulo: Cortez, 2001, p. 101-142.

NASCIMENTO, Jorge Carvalho do. Nota prévia sobre a palavra impressa no Brasil do século XIX- A biblioteca do povo e das escolas. In: CONGRESSO BRASILEIRO DE HISTÓRIA DA EDUCAÇÃO, 1., 2000, Rio de Janeiro. Anais eletrônicos... Rio de Janeiro: Sociedade Brasileira de História da Educação, 2000. Disponível em:< http://www.sbhe.org.br/novo/ congressos/cbhe1/anais/074_jorge_carvalho.pdf >. Acesso em: 20 out. 2009.

NERY, Alfredina. Biblioteca escolar: um jeito de ajeitar a escola. In: GARCIA, Edson Gabriel (Org.). Biblioteca escolar: estrutura e funcionamento. 2.ed. São Paulo: Loyola, 1998.

ORLANDI, Eni P. Nem escritor, nem sujeito: apenas autor. In: Discurso e leitura. Campinas: Editora da Unicamp, 1988.

As formas do silêncio: no movimento dos sentidos. 4.ed. Campinas: Editora da UNICAMP, 1997. (Coleção Repertórios).

Discurso e leitura: as formas do discurso. 5.ed. São Paulo: Cortez, 2000.

$2003 \mathrm{a}$.

A Linguagem e seu funcionamento: as formas do discurso. 4.ed. Campinas: Pontes,

A leitura e os leitores. 2. ed. Campinas: Pontes, $2003 b$.

Análise de discurso: princípios \& procedimentos. 5.ed. Campinas: Pontes, 2003c.

Michel Pêcheux e a Análise do Discurso. Estudos da Língua(gem), Vitória da

Conquista, n.1, p.9-13, jun. 2005. Disponível em: <http://www.cpelin.org/estudosda linguagem/n1jun2005/artigos/orlandi.pdf >. Acesso em: 10 jan. 2010. 
Análise de discurso. In: ORLANDI, Eni P.; LAGAZZI-RODRIGUES, Suzy. (Orgs.). Introdução às Ciências da Linguagem: discurso e textualidade. Campinas: Editora Pontes, 2006a.

Análise de discurso: conversa com Eni Orlandi. Entrevista concedida à Raquel Goulart Barreto. Teias, Rio de Janeiro, ano 7, n. 13-14, jan./dez., 2006 b.

Claude Lévi-Strauss, Michel Pêcheux e o estruturalismo. Com Ciência, n. 108,10 maio. 2009. Disponível em: <http://www.comciencia.br/comciencia/?Section=8\&edição $=52 \& \mathrm{id}=658>$. Acesso em: 10 out. 2009 .

PACÍFICO, Soraya Maria Romano. Argumentação e autoria: o silenciamento do dizer. 2002. Tese (Doutorado)- Faculdade de Filosofia, Ciências e Letras de Ribeirão Preto, Universidade de São Paulo, Ribeirão Preto, 2002.

PAIVA, Aparecida. A trama do acervo: a literatura nas bibliotecas escolares pela via do Programa Nacional Biblioteca da Escola. In: SOUZA, Renata Junqueira de (Org.). Biblioteca escolar e práticas educativas. Campinas: Mercado de Letras, 2009. p. 137-155.

PAIVA, Jane; BERENBLUM, André. Programa Nacional Biblioteca da Escola (PNBE)- uma avaliação diagnóstica, Pro-Posições, Campinas, v. 20, n. 1, p. 173-188, jan./abr. 2009.

Disponível em: <http://mail.fae.unicamp.br/ proposicoes/textos/58-artigos-paivaj_etal.pdf >. Acesso em: 20 set. 2009.

PÊCHEUX, Michel. O mecanismo do (des)conhecimento ideológico. In: ZIZEK, Slavoj (Org.). Um mapa da ideologia. Rio de Janeiro: Contraponto, 1996. p. 143-152.

Semântica e Discurso: uma crítica à afirmação do óbvio. Tradução de Eni Pulcinelli Orlandi et al. 3. ed. Campinas, SP: Editora da UNICAMP, 1997.

Papel da memória. In: ACHARD, Pierre et al. Papel da memória. Tradução de José Horta Nunes. Campinas: Pontes, 1999. p. 49-57.

O discurso: estrutura ou acontecimento. Tradução de Eni Puccinelli Orlandi. 3.ed. Campinas: Pontes, 2002.

PEREIRA, Magda Chagas. Algumas considerações sobre a leitura no hipertexto. ACB, v.3, n.3, 1998. Disponível em: < http://revista.acbsc.org.br/index.php/racb/article/view/ 328/387>. Acesso em: 10 out. 2009.

PERROTTI, Edmir. Biblioteca não é depósito de livros. [Entrevista concedida a Márcio Ferrari]. Nova escola, ed. 193, jun.2006. Disponível em: <http://revistaescola.abril.com. br/lingua-portuguesa/pratica-pedagogica/biblioteca-nao-deposito-livros-423601.shtml>. Acesso em: 9 dez. 2009

Sonhos e bibliotecas. Carta Escola, ed. 26, 9 maio. 2008. Disponivel em: <http://www.cartanaescola.com.br/edicoes/26/sonhos-e-bibliotecas>. Acesso em: 10 out. 2009. 
PERROTTI, Edmir; VERDINI, Antonio de Sousa. Estações do conhecimento: espaços e saberes informacionais. In: ROMÃO, Lucília Maria Sousa (Org.). Sentidos da biblioteca escolar. São Carlos: Gráfica e Editora Compacta, 2008. p. 13-39.

PESSOA, Fernando. O eu profundo e os outros eus. 3 ed. Rio de Janeiro: PocketOuro, 2008.

PIERUCCINI, Ivete. Biblioteca escolar, pesquisa e construção do conhecimento. In: ROMÃO, Lucília Maria Sousa (Org.). Sentidos da biblioteca escolar. São Carlos: Gráfica e Editora Compacta, 2008. p. 41-69.

QUEIROZ, Solange Palhano de. Information literacy: uma proposição expressiva para a biblioteca escolar. In: SILVA, Rovilson José da; BORTOLIN, Sueli (Orgs.). Fazeres cotidianos na biblioteca escolar. São Paulo: Polis, 2006.

QUINTANA, Mário. Caderno H. 2.ed. São Paulo: Editora Globo, 2006.

RAMAL, Andrea Cecília. Educação na cibercultura: hipertextualidade, leitura, escrita e aprendizagem. Porto Alegre: Artmed, 2002.

RIGOlETO, Ana Paula Cardoso; DI GIORGI, Cristiano Amaral Garboggini. Outros parceiros na biblioteca escolar: democratização e incentivo à leitura. In: SOUZA, Renata Junqueira de (Org.). Biblioteca escolar e práticas educativas. Campinas: Mercado de Letras, 2009. p. 219- 237.

ROMÃO, Lucília Maria Sousa. Na teia eletrônica, fragmentos da memória. In: MORELLO, Rosângela. (Org.). Giros na cidade: materialidade do espaço. Campinas: LABEURB/ NUDECRI- UNICAMP, 2004a.

. Nós, desconhecidos, na grande rede. Linguagem em (Dis)curso, Tubarão, SC, v. 5, 2004b. Disponível em: <http://www3.unisul.br/paginas/ensino/pos/linguagem/0501/04.htm>. Acesso em: 17 abr. 2009.

De areia e de silício: as tramas do discurso no livro eletrônico. Especulo, Madrid, n. 31, nov. 2005a. Disponível em: <http://www.ucm.es/info/ especulo/ numero31/silicio.html>. Acesso em: 17 abr. 2009.

. No país das maravilhas: uma metáfora sobre o dizer na rede. Letra Magna, ano 2, n.3, 2005b. Disponível em: <http://www.letramagna.com/lucilia_romao\%20.pdf >. Acesso em: 17 abr. 2009.

O cavalete, a tela e o branco: introdução à autoria na rede eletrônica. Delta, São Paulo, v.22, n.2, 2006. Disponível em: <http://www.scielo.br/pdf/delta/v22n2/ a04v22n2.pdf>. Acesso em: 17 abr. 2009

Heterogeneidade e memória: o sujeito na trama de vozes alheias. In: ROMÃO, Lucília Maria Sousa; GASPAR, Nádea Regina. (Orgs). Discurso midiático: sentidos de memória e arquivo. São Carlos: Pedro \& João Editores, 2008. p.95-112.

ROMÃO, Lucília Maria; PACÍFICO, Soraya Maria Romano. Era uma vez uma outra história: leitura e interpretação na sala de aula. São Paulo: DCL, 2006. 
ROSA, João Guimarães. Grande sertão: veredas. Rio de Janeiro: José Olympio, 1965.

SANTAELLA, Lúcia. Culturas e artes do pós-humano: Da cultura das mídias à cibercultura. São Paulo: Paulus, 2003.

2004.

Navegar no ciberespaço: o perfil cognitivo do leitor imersivo. São Paulo: Paulus,

SANTOS, Caroline Silva dos; SOUZA, Renata Junqueira de. Programas de leitura na biblioteca escolar: a literatura a serviço da formação de leitores. In: SOUZA, Renata Junqueira de (Org.). Biblioteca escolar e práticas educativas. Campinas: Mercado de Letras, 2009. p. $97-114$

SANTOS, Gildenir Carolino; AMARAL, Sergio Ferreira do. Rede de Conhecimento Digital (BED Net): metodologia para a construção da rede de bibliotecas escolares digitais. Revista Brasileira de Biblioteconomia e Documentação, São Paulo, v.2, n.1, p. 57-82, jan./jun. 2006. Disponível em: <http://www.febab.org.br/rbbd/ojs-2.1.1/index.php/rbbd/article/ view/6/22>. Acesso em: 10 jul. 2009.

SANTOS, Rogério Santanna dos. Cresce o acesso às TICs, mas ainda é grande o desafio de democratizá-las a todos os brasileiros. In: COMITÊ GESTIR DA INTERNET NO BRASIL. Pesquisa sobre o uso das tecnologias da informação e da comunicação 2008. São Paulo: [s.n.], 2009. p. 45-48.

SARAMAGO, J. Todos os nomes. São Paulo: Companhia das Letras, 1997.

A caverna. 3.ed. São Paulo: Companhia das Letras, 2000.

As intermitências da morte. São Paulo: Companhia das Letras, 2005.

SARTRE, Jean-Paul. As palavras. 5.ed. Rio de Janeiro: Difel, 1978.

SAUSSURE, Ferdinand de. Curso de Linguística Geral. 30 ed. São Paulo: Editora Cultrix, 2003.

SERRANO, Filipe. Redes sociais são novo alvo de censura. Estadão, 22 jun. 2009.

Disponível em: <http://www.estadao.com.br/noticias/tecnologia+link,redes-sociais-sao-novoalvo-de-censura,2807,0.shtm>. Acesso em 20 ago. 2009.

SILÊNCIO na biblioteca. 2009. Disponível em:<http://br.groups.yahoo.com/group/ bibamigos/message/25340>. Acesso em 10 maio. 2009.

SILVA, Ezequiel Theodoro da. Biblioteca escolar: quem cuida? In: GARCIA, Edson Gabriel (Org.). Biblioteca escolar: estrutura e funcionamento. 2.ed. São Paulo: Loyola, 1998.

(Coord.). A leitura nos oceanos da Internet. São Paulo: Cortez, 2003 
SILVA, Lilian Lopes Martin da; FERREIRA, Norma Sandra de Almeida; SCORSI, Rosalina de Ângelo. Formar leitores: desafios da sala de aula e da biblioteca escolar. In: SOUZA, Renata Junqueira de (Org.). Biblioteca escolar e práticas educativas. Campinas: Mercado de Letras, 2009. p.49-67.

SILVA, Luiz Antonio Gonçalves da. As bibliotecas dos jesuítas: uma visão a partir da obra de Serafim Leite. Perspectivas em Ciência da Informação, v. 13, n.2, p. 219-237, maio/ago. 2008. Disponível em: <http://www.eci.ufmg.br/pcionline/index.php/pci/ article/viewFile/ 189/483>. Acesso em: 10 jul. 2009.

SILVA, Obdália Santana Ferraz. Nos labirintos da web: possibilidades de leitura e produção textual nos cenários digitais. 2006. Dissertação (mestrado) - Universidade do Estado da Bahia, Salvador, 2006.

SILVA, Rovilson José da. Biblioteca escolar: estrutura e funcionamento. In: SOUZA, Renata Junqueira de (Org.). Biblioteca escolar e práticas educativas. Campinas: Mercado de Letras, 2009. p. 115-135.

SILVA, Rovilson José da; BORTOLIN, Sueli. Reflexões sobre a leitura e a biblioteca escolar. In: __ (Orgs.). Fazeres cotidianos na biblioteca escolar. São Paulo: Polis, 2006.

SILVA, Waldeck Carneiro da. Miséria da biblioteca escolar. 3. ed. São Paulo: Cortez, 2003.

SORJ, Bernardo. Brasil@ povo.com: a luta contra a desigualdade na sociedade da informação. Rio de Janeiro: Jorge Zahar Editor; Brasília: UNESCO, 2003.

TFOUNI, Leda Verdiani; PANTONI, Rosa Virgínia. Sobre a ideologia e o efeito de evidência na teoria da Análise do Discurso francesa. Achegas, n. 25, set./out., 2005. Disponível em: $<$ http://www.achegas.net/numero/vinteecinco/leda_e_rosa_25.htm >. Acesso em: $10 \mathrm{mar}$. 2010.

TREVISAN, Rosa (Coord.). Michaelis: moderno dicionário da língua portuguesa. São Paulo: Editora Melhoramentos, 1998. Disponível em: <http://michaelis.uol.com.br/ moderno/portugues/index.php?lingua=portugues-portugues\&palavra=biblioteca $>$. Acesso em: 10 nov. 2009.

VÁLIO, Else Benetti Marques. Biblioteca escolar: uma visão histórica Transinformação, Campinas, v. 2, n. 1, p. 15-24, jan./abr, 1990. Disponível em: <http://biblioteca.ricesu. com.br/art_link.php?art_cod=2132> Acesso em: 21 dez. 2009.

VARGAS, José Israel. A informação e as redes eletrônicas. Ciência da Informação, v. 23, n.1,1994. Disponível em: <http://revista.ibict.br/ciinf/index.php/ciinf/article/view/ 1160/805>. Acesso em: 20 jun. 2009.

VERGUEIRO, Waldomiro de Castro Santos. Desenvolvimento de coleções: uma nova visão para o planejamento de recursos informacionais. Ciência da informação, Brasília, v. 22, n. 1, p.13-21, jul./abr. 1993. Disponível em: <http://revista.ibict.br/index.php/ciinf/article/view Article/1208>. Acesso em: 10 maio 2009. 
VIOLA, Paulinho da; CARVALHO, Hermínio Bello de. Timoneiro. Intérprete: Paulinho da Viola. In: VIOLA, Paulinho da. Bebadosamba. [S.1.]: BMG Brasil, 1996. 1 CD. Faixa 2.

WERTHEIM, Margaret. Uma história do espaço: de Dante à Internet. Tradução de Maria Luiza X de A. Borges. Rio de Janeiro: Jorge Zahar Editor, 2001.

WOLTON, Dominique. Internet, e depois? Uma teoria crítica das novas mídias. Porto Alegre: Sulina, 2003. 
ANEXOS

\section{ANEXO 1}

Exposição

Biblioteca Escolar: Tudo começa aqui

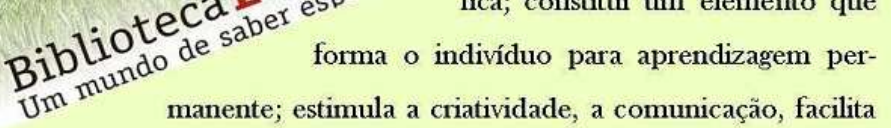

A biblioteca escolar é um instrumento de desenvolvimento do currículo e permite o fomento da leitura e da formação de uma atitude cientía recreaçäo, apoia os docentes em sua capacitação e lhes oferece informaçäo necessária para tomada de decisäo na aula. (OEA, 1985, p.21-22)

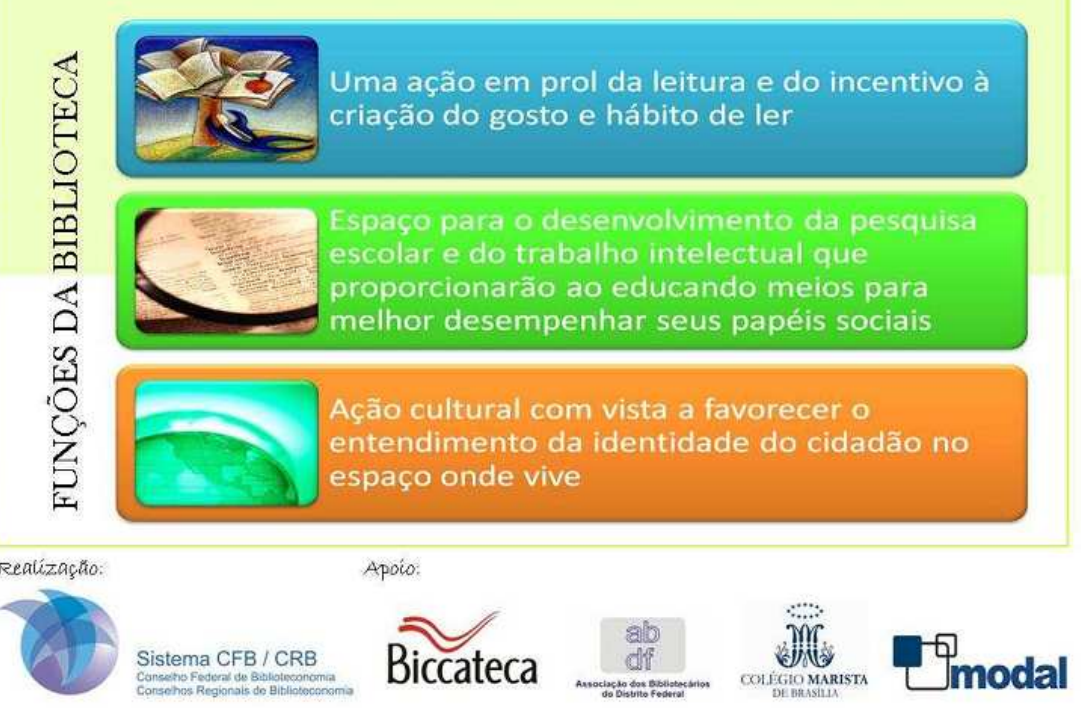




\section{OBJETIVOS DA BIBLIOTECA ESCOLAR}

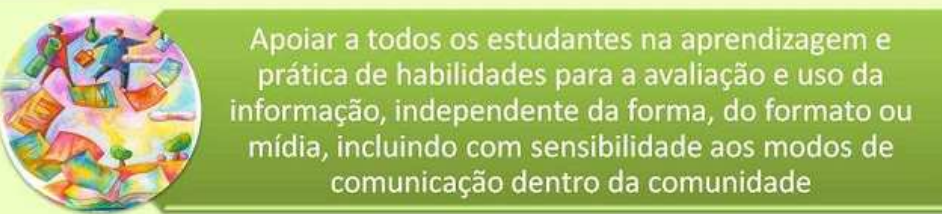

Favorecer o acesso a recursos locais, regionais, nacionais e globais e a oportunidade para que os estudantes exponham diferentes idéias, opiniões e experiências

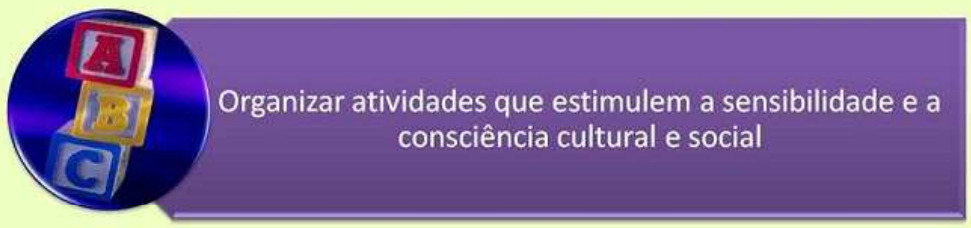

Trabalhar com estudantes, professores, administradores e pais para realizar a missão da escola

Proclamar a ideia de que a liberdade de expressão e o acesso à informação são essenciais à efetiva e responsável cidadania e participação na democracia

Promover a leitura, recursos e serviços da Biblioteca a toda a comunidade escolar e à comunidade externa 
ANEXO 2

Volume 1, Número 5

Nacional

\section{Manifesto em Defesa da Biblioteca Escolar}

No contexto do projeto de ensino-aprendizagem, a biblioteca escolar apresenta-se como um centro de aprendizagem cuja função pedagógica está relacionada a: a) uma ação em prol da leitura, do incentivo à criação do gosto de ler; b) a pesquisa escolar e ao trabalho intelectual que proporcionarão ao educando meios para melhor desempenhar seus papéis sociais; e c) a ação cultural com vistas a favorecer o entendimento da identidade do cidadão no espaço onde vive. A biblioteca escolar não somente lida com as demandas do aluno, mas, sobretudo, atua no contexto do projeto político-pedagógico da escola, através do trabalho conjunto com o professor e a gestão escolar.

Segundo o Manifesto da U NESCO, a biblioteca escolar é espaço que "[...] promove serviços de apoio à aprendizagem e ivros aos membros da comunidade escolar, oferecendo-lhes a possibilidade de se tornarem pensadores críticos e efetivos usuários da informação, em todos os formatos e meios", ou seja, competentes em informação.

As entidades e pessoas físicas que assinam este Manifesto expõem sua preocupação com o momento pelo qual passa a educação no Brasil, com baixos índices de aprendizagem dos alunos, mensurados tanto pelo Sis tema de Avaliação da Educação Básica (SAEB), quanto pelo Programa Internacional de Avaliação de Alunos (PISA), demonstrando que os estudantes brasileiros não possuem competência em leitura e escrita. Diante deste fato, acredita-se que se as instituições de ensino investirem na criação de espaços de bibliotecas bem equipadas, com acervos que atendam ao projeto poítico pedagógico das escolas e administradas por profissionais bibliotecários, esta triste realidade poderá sofrer significativa transformação.

Alguns documentos elaborados pelo Ministério da Educação apontam para a importância da biblioteca na prática da leitura escrita, um dos maiores problemas da educação atualmente, dentre estes citam-se os Parâmetros Curriculares Nacionais (PCN's), que, no módulo de Língua Portuguesa cita a biblioteca como um espaço apto a influenciar e incentivar a prática da leitura e escrita.

O Programa Nacional Biblioteca da Escola (PNBE) distribu acervos para bibliotecas escolares. No que pese ser esta a única iniciativa desenvolvida no âmbito da federação para as bibliotecas escolares ${ }^{1}$, é tácito afirmar que tal Programa não atende as expectativas do contexto no qual se inserem as disquaresentadas, pois, se cas e muito menos bibliotecários, como estão sendo dinamizados esses acervos?

De fato, os diagnósticos existentes no País acerca das condicões das bibliotecas escolares, bem como as decisões emanadas do Tribunal de Contas da União (TCU) em seus Acórdãos ก. $604 / 2004$ e $n^{\circ} 1287 / 2005$ apontam que a grande maioria dos responsáveis técnicos e diretores das escolas não tem noção dos serviços que podem se oferecidos pelas bibliotecas, que impede a criação de muitas oportunidades e que essas bibliotecas atuem como ambiente de busca e aprimoramento de conhecimentos. Os diretores das cos não têm domínio sobre a concepção do funcionamento de uma biblioteca e se arriscam ao apontar a dimensão do espaço físico destinado a leitura como única diferença entre biblioteca e sala de leitura: a biblioteca seria aquela com maior espaço físico, a despeito da constituição do acervo, serviços oferecidos nível de tratamento e organização das obras. Ainda, é oportuno destacar que, na maioria dos casos, o horário de atendimento não é regular nem suficiente para atender aos estudantes, sendo que os raros freqüentadoes pouco usam ou têm consciência de suas potencialidades em termos de serviços. Os da dos do Censo Escolar 2004 destacam que $51,7 \%$ dos alunos do ensino básico e profissional dispõem de bibliotecas escolares
não permitem inferir que estes discentes de fato as usem, ou pelo menos, reconheçam a exisspaços para me diar seu processo de ensinoaprendizagem.

Considerando que uma das atividades a ser desenvolvida pela biblioteca escolar é o incentivo à leitura, o Instituto PróLeitura (IPL) efetuou, no primeiro semestre de 2008 , a segunda edição da pesquisa Retratos da Leitura no Brasil, que se constitui no principal estudo sobre comportamento do leitor no $\mathrm{Pa}$ is, na expectativa de contribui para a avaliação dos impactos das políticas públicas que possibilitem o acesso ao livro e à leitura, visando identificar as que efetivamente trouxeram resultados no incentivo ao gosto de ler.

Dentre suas conclusões, com relação aos dados levantados sobre o uso de bibliotecas, pesquisa aponta para a necessidade de a escola assumir verdadeiramente seu papel de formadora de leitores, intensificando sua ação em todas as direções que se relacionam com o gosto pela leitura.

Ressalte-se que biblioteca escolar, embora se constitua em um espac ção, apresenta-se carente das condições adequadas para ofertar um serviço cidadão, no sentido de que está impedida de viabilizar um processo de democratização da informação com amplo acesso aos meios de cultura, uma vez que a sua existência está condicionada única e exclusivamente à presença de acervo, e não à oferta de serviços capazes de promover o acesso aos saberes registrados nos artefatos culturais que a biblioteca escolar deve disponibilizar. 
Nessa abrangência, o Sistema CFB/CRB compreende que o trabalho da biblioteca escolar há de ter como ponto de partida o contexto da escola, seu projeto pedagógico e a cultura geral que compõe o conjunto de saberes que fundamentam e dão sentido ao modo de vida e à existência de cada membro da comunidade escolar. Isto implica analisar uma dada realidade, refletindo sobre as condições existentes e prever as formas alternativas de ação para superar as dificuldades ou para alcançar os objetivos desejados pela proposta pedagógica desenvolvida no âmbito da escola.

O gasto de numerário público, como já destacado, em simples aquisição e distribuição de acervo, principalmente composto de livros, sem abranger a existência, organização e manutenção de bibliotecas fere 0 interesse público, já que em última instância, esses recursos são extraídos dos cofres públicos a partir da arrecadação efetuada através do contribuinte, configurando-se em malbaratação do patrimônio cultural, que falsamente está sendo construído, pois a informação não cumpre o seu potencial de circulação, seja em termos sociais ou geográficos ou melhorando o nivel de conhecimento do alunado e dos educadores em geral.

Mais do que propor o exato modelo de bibliotecas escolares, as organizações abaixo assinadas reivindicam o respeito aos princípios estabelecidos n Constituição Federal (1988), no que tange ao direito do cidadão em ter acesso a um espaço no qual a informação concretiza se papel social, democratizante, vez que não se pode pretende que o acervo não processado de forma técnica, científica, atenda a essa função que, por ser socia é garantia da construção da $\mathrm{Ci}^{-}$ dadania. E exatamente, diga-se de outro modo, a informação que se organiza, processa e se dissemina, após receber o tratamento adequado, que poderá atender ao cidadão em amplo raio de demandas e níveis de compreensão.

Brasília, 20 de março de 2009.
Assinam o Manifesto:

Conselho Federal de Biblioteconomia

Conselho Regional de Biblioteconomia - $1^{\text {a }}$ Região

Conselho Regional de Biblioteconomia - $\mathbf{2}^{\text {a }}$ Região

Conselho Regional de Biblioteconomia - $3^{a}$ Região

Conselho Regional de BiblioteConselho Regional de Biblioteconomia - $4^{a}$ Região Conselho Regional de Biblioteconomia - $5^{a}$ Região Conselho Regional de Biblioteconomia - $6^{a}$ Região

Conselho Regional de Biblioteconomia - $7^{a}$ Região

de BiblioteConselho Regional de Biblioteconomia - $8^{a}$ Região Conselho Regional de Biblioteconomia - 9a Região Conselho Regional de Biblioteconomia - $10^{\text {a }}$ Região

Conselho Regional de Biblioteconomia - 11 a Região Conselho Regional de BiblioteConselho Regional de conomia - 12a Região Conselho Regional de Biblioteconomia - 13a Região Conselho Regional de Biblioteconomia - 14a Região Conselho Regional de Biblioteconomia - 15a Região

\section{ATIVIDADES A SEREM REALIZADAS NO DIA 23 DE ABRIL DE} 2009 MOVIMENTO EM PROL DA BIBLIOTECA ESCOLAR

1. Consultar os Assessores Jurídicos par impetrar ações junto aos Ministérios Públicos Estaduais e Municipais em função da criação de leis para implantação de espaços de leitura (biblioteca, sala de leitura, pontos de leitura) sem a presença de bibliotecários. Responsabilidade: Conselho Regional e Conselho Federal.

2. Elaboração de um manifesto a favor da biblioteca escolar a ser publicado em todos os jornais do país. Responsabilidade: Conselho Federal (elaboração) e Conselho Regional (publicação).

3. Distribuição do folder do Projeto Mobilizador para todos os conselhos estaduais e municipais de educação, se possivel com a presença de membros do Regional. Responsabilidade: Conselho Regional.

4. Eleger uma figura pública para apoiar o movimento. Responsabilidade: Conselho Federal.

5. Levantar e expor as boas práticas existentes no pais. Responsabilidade: Conselho Federal com apoio dos Conselhos Regionais.

6. Buscar marcar audiências públicas nas Assembléias Legislativas Estaduais e na Câmara Federal visando discutir os aspectos da necessidade de implantação da biblioteca escolar. Responsabilidade: Conselho Federal (âmbito nacional) Conselhos Estaduais (âmbito de cada jurisdição).

7. Conclamar as escolas para realizarem um evento, no dia, para lançamento do Manifesto em cada região. Responsabilidade: Conselho Regional (âmbito de cada jurisdição).

8. Elaborar e divulgar amplamente um boletim eletrônico especial sobre a temática. Responsabilidade: Conselho Federal (elaboração do boletim Conselhos Regionais (distribuição do boletim).

9. Divulgar o projeto mobilizador junto a todos partidos políticos. Responsabilidade: Conselho Federal de Biblioteconomia com auxilio dos Regionais. Para o PMDB, o CRB11 buscará auxiliar no agendamento da reunião. 
ANEXO 3

\author{
Assunto: \\ CARTA DE BRASILIA EM DEFESA DA BIBLIOTECA ESCOLAR \\ Data: \\ Tue, 12 Jun 2007 11:20:53 -0300
}

\title{
CARTA DE BRASILIA DO SISTEMA CONSELHO FEDERAL E REGIONAIS DE BIBLIOTECONOMIA EM DEFESA DA BIBLIOTECA ESCOLAR
}

Segundo a UNESCO, a biblioteca escolar é o espaço que "[...] promove serviços de apoio à aprendizagem e livros aos membros da comunidade escolar, oferecendo-lhes a possibilidade de se tornarem pensadores críticos e efetivos usuários da informação, em todos os formatos e meios".

Acompanhamos com preocupação o momento por que passa a educação no Brasil, com baixos índices de aprendizagem dos alunos, demonstrando que eles não possuem competência em leitura e escrita. Diante desse fato, acreditamos que se as instituições de ensino investirem na criação de espaços de bibliotecas bem equipadas, com acervos que atendam o projeto político pedagógico das escolas e administradas por profissionais Bibliotecários, está triste realidade poderá sofrer significativa transformação.

Alguns documentos elaborados pelo Ministério da Educação apontam para a importância da biblioteca na prática da leitura e escrita, um dos maiores problemas de nossa educação atualmente. Podemos citar os Parâmetros Curriculares Nacionais (PCN's), que, no módulo de Língua Portuguesa, cita a biblioteca como um espaço apto a influenciar e incentivar a prática da leitura e escrita.

Recomenda, ainda, que seja um local de fácil acesso aos livros e materiais disponíveis e que a escola estimule a frequência ao espaço, contribuindo assim para tal a prática.

Nos debates do programa Salto para o Futuro, os especialistas que participam das discussões sobre alfabetização e letramento, apontam a biblioteca escolar como espaço de excelência na aquisição de leitura e escrita.

O Plano Nacional de Biblioteca Escolares (PNBE) do MEC, distribui acervos para bibliotecas escolares. Se as escolas não possuem bibliotecas e muito menos bibliotecários, como está sendo dinamizado este acervo?

A Lei 10.172 de 2001, que aprova o Plano Nacional de Educação, determina que as escolas de ensino fundamental e médio, para o seu funcionamento, deverão ter um padrão mínimo nacional de infra-estrutura, compatível com o tamanho dos estabelecimentos e com a realidade regional. Deverão ter espaço para biblioteca e atualização e ampliação do acervo das existentes.

Determina ainda, que a partir do segundo ano da vigência deste plano, o MEC só deverá autorizar a construção e funcionamento de escolas que atendam aos requisitos e infraestrutura, entre estes, a construção de uma biblioteca.

É de responsabilidade do MEC a fiscalização e cumprimento da Lei, assim como não permitir que novas escolas sejam abertas sem que possuam uma biblioteca.

A qualidade da educação acha-se intimamente ligada à oferta, pela escola, de meios, instrumentos, equipamentos e suporte para que o educando integre-se à cultura, assimile, processe e produza enquanto sujeito do processo civilizatório, sujeito da construção da cidadania. Este o sentido das disposições do art. 205 da carta magna, garantidores da universalização da educação, como um direito de todos e dever do Estado, visando seu preparo como pessoa, para o exercício da cidadania e sua qualificação para o trabalho.

Também, a principiologia que sedimenta a ministração do ensino no pais, consoante explicitação do art. 206 do texto constitucional, identifica bases na igualdade de condições de acessibilidade a escola; liberdade de aprender, ensinar, pesquisar e divulgar o pensamento, a arte e o saber. Em todos os pontos do capítulos do capítulo 1ll, Seção 1 "da Educação", 
explicita-se o compromisso do estado com a qualidade da educação. A Lei no 4.084, de 30 de junho de 1962, dispõe sobre a profissão de Bibliotecário e regula seu exercício. Em seu Art. 6 o determina "[...] que, entre as atribuições dos Bacharéis em Biblioteconomia, estão a organização, direção e execução dos serviços técnicos de repartições públicas federais, estaduais, municipais e autárquicas e empresas particulares".

O exercício dessas funções por leigo constitui uma infração a legislação vigente e, principalmente, fere o direito constitucional do cidadão em receber a prestação de serviços por profissional especializado e habilitado, consoante disposição do inciso XIII do artigo $5^{\circ}$. da Constituição Federal, que dispõe sobre a liberdade de exercício de trabalho, ofício ou profissão, desde que atendidas as qualificações profissionais que a lei estabelecer.

Ressalte-se que biblioteca escolar, enquanto ente representativo de um espaço de aquisição e disseminação de cultura e informação, apresenta-se carente de um serviço cidadão, no sentido de que não se pode viabilizar um processo de democratização da informação sem amplo acesso aos meios de cultura.

Entendemos que a informação contida em uma biblioteca, uma vez processada por um profissional bibliotecário, é a que mais diretamente atingirá o destinatário da mesma: o usuário com quem interage, o que traz a ele suas demandas.

É exatamente no espaço da biblioteca escolar que a informação é processada com vistas à disseminação imediata ao usuário discente - e ao docente também; ao acesso adequado. É neste espaço que a informação concretiza seu papel social, democratizante, vez que não se pode pretender que o acervo não processado de forma técnica, cientifica, atenda a essa função que, por ser social é garantia da construção da cidadania. É exatamente, repita-se, a informação que se organiza, processa e se dissemina após receber o tratamento adequado, que poderá atender ao cidadão em amplo raio de demandas e níveis de compreensão.

Este, portanto, o real papel do Bibliotecário na construção da educação cidadã.

Brasília, 23 de março de 2007.

Conselho Federal de Biblioteconomia

Conselho Regional de Biblioteconomia - $1^{\text {a }}$ Região

Conselho Regional de Biblioteconomia - 2a Região

Conselho Regional de Biblioteconomia - $3^{\text {a }}$ Região

Conselho Regional de Biblioteconomia - $4^{a}$ Região

Conselho Regional de Biblioteconomia - $5^{\text {a }}$ Região

Conselho Regional de Biblioteconomia - $6^{\text {a }}$ Região

Conselho Regional de Biblioteconomia $-7^{\mathrm{a}}$ Região

Conselho Regional de Biblioteconomia - $8^{\text {a }}$ Região

Conselho Regional de Biblioteconomia - $9^{\text {a }}$ Região

Conselho Regional de Biblioteconomia - 10 Região

Conselho Regional de Biblioteconomia $-11^{\text {a }}$ Região

Conselho Regional de Biblioteconomia - $12^{\mathrm{a}}$ Região

Conselho Regional de Biblioteconomia - $13^{\mathrm{a}}$ Região

Conselho Regional de Biblioteconomia $-14^{\text {a }}$ Região 
ANEXO 4

\section{LEI N 12.244, DE 24 DE MAIO DE 2010}

Dispõe sobre a universalização das bibliotecas nas instituições de ensino do País.

\section{O PRESIDENTE DA REPÚBLICA}

Faço saber que o Congresso Nacional decreta e eu sanciono a seguinte Lei:

Art. 1 As instituições de ensino públicas e privadas de todos os sistemas de ensino do País contarão com bibliotecas, nos termos desta Lei.

Art. 2 Para os fins desta Lei, considera-se biblioteca escolar a coleção de livros, materiais videográficos e documentos registrados em qualquer suporte destinados a consulta, pesquisa, estudo ou leitura.

Parágrafo único. Será obrigatório um acervo de livros na biblioteca de, no mínimo, um título para cada aluno matriculado, cabendo ao respectivo sistema de ensino determinar a ampliação deste acervo conforme sua realidade, bem como divulgar orientações de guarda, preservação, organização e funcionamento das bibliotecas escolares.

Art. 3 Os sistemas de ensino do País deverão desenvolver esforços progressivos para que a universalização das bibliotecas escolares, nos termos previstos nesta Lei, seja efetivada num prazo máximo de dez anos, respeitada a profissão de Bibliotecário, disciplinada pelas Leis n 4.084, de 30 de junho de 1962, e 9.674, de 25 de junho de 1998.

Art. 4 Esta Lei entra em vigor na data de sua publicação.

Brasília, 24 de maio de 2010; 189 da Independência e 122 da República.

LUIZ INÁCIO LULA DA SILVA

Fernando Haddad

Carlos Lupi 
ANEXO 5

SEGUNDA-FEIRA, 16 DE NOVEMBRO DE 2009

\section{Apresentando a Biblioteca escolar}

Excelente iniciativa do CRB em mostrar a Biblioteca Escolar através de uma exposição. É uma forma de levar a toda sociedade brasileira o que ela faz, sua importância dentro de uma instituição de ensino e do quanto a biblioteca bem equipada,com um acervo atualizado e uma equipe homogênea comandada por um (a) profissional de biblioteconomia pode auxiliar e colaborar com a aprendizagem e o ensino. Uma escola sem biblioteca, é como um corpo sem coração e cérebro. Faltando conhecimento e o acesso a ele, e faltando calor e atenção, qualquer escola fica "aleijada" sem esse espaço tão significativo. Afinal, uma biblioteca escolar não é somente um repositório do saber mas sim, um espaço alegre, vivo onde as pessoas se encontram, interagem e trocam informações e reforçam as amizades. Nesse exato momento, olho sob a tela de meu computador e observo as mesas da bibliotecas ocupadas por jovens do ensino médio que estudam, debatem, conversam, tornando o espaço cheio de vida e alegria. Os livros são importantes? Sem dúvida. Mas somente as pessoas que frequentam uma biblioteca é que dão vida ao ambiente e aos livros que, enquanto aguardam nas prateleiras sua vez de serem manuseados, ficam temporáriamente inanimados, sem vida. $\mathrm{E}$ a diferença que uma biblioteca faz na vida de uma criança e de um jovem, sem dúvida é grande se comparado com aqueles que nunca entraram em uma biblioteca, nem mesmo para conhecer. Sei que para muitos, pode até parecer que estou sendo tendenciosa em defender tanto esse espaço mas, vamos ser sinceros: Como não elevar um ambiente que convivo há tantos anos e que devido a essa experiência, tenho a plena certeza que é algo benéfico para o estudante, professores e todos que a frequentam? Parabéns mais uma vez a essa iniciativa que o CRB e todos os orgãos ligados a bibliotecas estão fazendo para que mude de vez essa imagem tão negativa da biblioteca escolar. Vamos reforçar esse apoio? Contos com vocês! 


\begin{abstract}
ANEXO 6
Minha nova missão na biblioteca escolar

2008 novembro 6

by biblio 20
\end{abstract}

Estou trabalhando como auxilar em uma biblioteca escolar da prefeitura de $\mathrm{BH}$.Comecei minhas atividades no último dia 23 e para mim tem sido um aprendizado muito grande.É verdade que a vontade de "mudar o mundo" de um dia pra o outro, logo vem à cabeça.Mas as coisas não caminham e nem funcionam desse jeito.É necessário muita cautela.Mas quero contribuir o máximo que posso para que a biblioteca seja realmente um lugar onde as crianças- neste caso por ser uma biblioteca escolar- possam encontrar um bom livro pra ler e, acima disto, um lugar agradável também.E minha primeira tarefa é...contar histórias para crianças da $4^{\text {a }}$ série em uma "tarde de autógrafos" marcada pela professora de literatura, onde os alunos irão autografar para os pais os livros por eles mesmos confeccionados.

E assim espero eu contribuir para a implementação de projetos outrora "estacionados" e que agora, quem sabe, podem voltar a serem realizados a partir da força de vontade de cada um de nós envolvidos na biblioteca.Acreditar vale a pena.... 


\section{ANEXO 7}

\section{quinta-feira, 6 de março de 2008}

Desespero pairando pelos ares fungóginos...

Cara, tem dia que dá um desespero total neste lugar. Imagine, 10.000 livros para cadastrar e gente te pedindo livros didáticos que você não sabe se tem, assuntos temáticos que exigiriam um resumo dos livros...você fica louco se levar muito a sério. O que eu faço? respiro fundo e vou. Sento com meus usuários alunos para ver do que precisam e como vão indo nas matérias, fico atento aos professores e pesquiso coisas antes até que me peçam, mexo com a cabeça dos alunos da forma que consigo para levarem a sério os estudos e lerem também a leitura do prazer...

Além do castelo de livros que fiz com a pergunta: "Para que servem os livros não lidos", para a qual a resposta de alguns foi "para queimar, a maioria deles" ou "estes livros são velhos, quero ler coisa nova"(plena desculpa para não ler nada), ando colando poemas chão do colégio afora e acho que para estes tenho mais leitores do que para os livros. Fiz algumas pilhas de livros no chão de modos que tropecem e derrubem...sei que pode surgir algum diálogo a partir destas coisas "estranhas" que tenho feito. Não me importo de não catalogar 1000 livros por dia, mas me importo se não conseguir uma boa linha de comunicação com os estudantes. Esta comunicação está acontecendo aos poucos, uns eu contacto via orkut(de fora pois a escola, por ser antiquada, não permite que os alunos acessem e que eu possa com eles manter um diálogo no meio em que gostam e estao acostumados. Com outros o diálogo e o inicio de um aprendizado diferenciado está vindo a partir do meu levantamento sutil de preferências. É certo que tenho alguns impecilhos por aqui. Uma pessoa que dá bronca quando um aluno desenha na lousa da biblioteca (porque pediu minha permissão e eu deixei se expressar), uma escola que manda os alunos que não tem o livro "de castigo" para a biblioteca e os que chegam atrasados também. Professores não leitores que querem que os alunos leiam e um certo descaso com as necessidades da biblioteca por livros mais atualizados e até por uma impressora que imprima as etiquetas corretamente. Mas, fora isto a biblioteca vai bem e um tanto quanto orgulhosa pelos elogios recebidos de professores como:"fico feliz em ver que a biblioteca está viva, ela conversa com a gente"...?(coloco bilhetes por todos os lados...propaganda subliminar para fazer os alunos repensarem sua repulsa por leitura. Bom, estantes lotadas, muito trampo... acho que tenho que ir...volto quando puder...té. 


\section{ANEXO 8}

\section{segunda-feira, 10 de março de 2008}

\section{Minha primeira "Hora do Conto"}

Segunda feira, um avalanche de jornais e revistas que chegam no fim de semana cai na minha cabeça quando entro na recepção da escola. Ao abrir a porta da biblioteca, crianças apressadas vão trançando pelos corredores. Elas vasculham o armário individual e pegam seus livros didáticos da próxima aula. Ah que inveja os livros de romance sentem dos livros didáticos. Se pudessem acompanhar aquelas crianças nas aulas, ficarem quentinhos ali, guardados nos armários esperando a hora de serem folheados e lidos.

Segunda terremoto! Carimbar jornais mil, Veja, revista disto e daquilo. grampear coisas. alunos pedindo livros didáticos que esqueceram em casa e a danada da catalogação por fazer. dos 10.000, já fiz 1000. Magros dez por cento do que já deveria estar pronto para atendem melhor meus pupilos. Olho no relógio e, entre um atendimento e outro, tudo passou tão rápido. dez horas da manhã, assim, do nada. [pensando]O TEMPO É COMO UM SORVETE, NÃO ADIANTA QUERER GUARDAR NO BOLSO PRA CHUPAR DEPOIS, ELE DERRETE, VAI-SE ENTRE OS DEDOS. O MELHOR MESMO É LOTAR DE CALDA DE CHOCOLATE E COMÊ-LO NA HORA, SENTINDO CADA MOLÉCULA DO SEU SABOR.Mas o pensamento não pode divagar muito, devo tomar um café para prosseguir com a brincadeira feliz de estar nesta biblioteca, atender almas sedentas daquilo que nem sabem que estão, dar comida invisível a mentes voláteis. Atravesso o corredor e começo a tomar meu café, não bem café, um chá "mata leão" da pior espécie. Não sei quem instituiu este chá chato como chá para servir em toda a empresa, mas é dele que bebo todos os dias para molhar o pão na boca e engolir correndo o bolo. Afinal não vejo a hora de voltar para os meus amigos livros e para meus clientes, os usuários. Diversão sem preço. Olho pela porta para ver se não caiu nenhum inseto em minha teia. ainda não. Hoje de manhã consegui pegar uma mosquinha na teia. Coloquei um jornal onde estava a manchete "Será que o computador vai nos entender? " embaixo do teclado de um dos computadores da biblioteca. Isto era uma armadilha. Quem leria a manchete e se interessaria pelo conteúdo? Não demorou muito, um dos adolescentes mais bagunceiros que conheço na escola caiu direitinho. Simples e naturalmente, pegou o jornal e começou a ler e a sorver o conteúdo. "muito bom Rudi, ponto pra você, pegou mais um". Lembrei-me da festa do sovete onde umas crianças leram uma poesia que imprimi de preguei no chão do páteo, tirei até foto. Gritei por dentro: "P. Q.P. funciona !" mas abafei o grito, afinal estava em uma escola e não ia ficar bem.

Olho pela porta de novo. Um serzinho pequeno cruza pra lá, depois pra cá e ...entra. Dali apouco vários deles aparecem. É a classe do pré-escolar. Gente em miniatura aos montes, anteninhas ligadissimas, chega a dar até choque quando encosta...tzzz. Poxa, eu havia combinado de contar uma historia para eles. Na correria não preparei nada mas iria improvisar. Seria fácil como contar uma historia para a Anne, minha pequena de 9 . Afastei os moveis para dar espaço aos pequenos soldadinhos e bailarinas. Eles iam sentando aos poucos. Sempre perguntando muito, mexendo em tudo....santa bagunça, eu adoro isto!. Prefiro do que o gelo do nada fazer e nada ter para fazer...adoro arrumar a bagunça quando eles saem. São uns furacõezinhos maravilhosos que me enchem a alma de esperança nos leitores do futuro. Perguntadeiros, conversadeiros, espertos pedacinhos de gente. Peguei um livro que não fosse muito extenso e comecei a contar uma historia de princesa, a princesa "Mãe d'água". A principio me pareceu uma historinha que os preparava para escutar lendas da amazônia, mas 
ao final era coisa mais requintada. Tinha amor, paixão, Conquistas de um principe guerreiro e um nascimento. Dai tinha uma separação entre os pais e o filho ficava com o pai. Dai o pai casava com outra porque a mãe do menino sumiu por muito tempo procurando a avó dele. Bem, achei complicadinha a historia que eu mesmo escolhi a esmo...mas eu ia parando e perguntando...O que foi que aconteceu até agora? Um japinha era o melhor de todos. Ele repetia tudo que eu tinha lido bem certinho. Um resumo preciso. Outros tentavam, mas o japinha era imbatível, o melhor. Na frente tinha uma pequena bailarina de cabelinhos encaracolados que também não dava mole. Respondia certinho que o pai separou da mãe [eu pensando] cara, que historia complicada...será que é para prepara-los para a sociedade real? aquela que prega que casar é o ideal mas que ao fim tem tanta separação de casais? Me aventurei pela historia a dentro. As vezes com medo do que viria, as vezes torcendo para continuar, depois para acabar logo. Quando acabou, morri por dentro. Foi muito bom. Ter aquela atenção que parecia meio desatenciosa, mas que estava ali, na ponta da lingua quando eu perguntava. Dai, eles se foram agradecendo pela historia.Furacaneando pra cá e pra lá, a professora os juntou perto da porteira da biblioteca...uma portinha balcão que está lá nem sei pra que...talvez para proteger os bibliotecários anteriores daqueles pequenos tornados. Eu quero mais é que eles venham e derrubem tudo. Construo de novo com o maior prazer. E esta foi a minha primeira hora do conto. Espero melhorar muito, mas gostei do que senti ao contar a historia. Era um misto de poder de locutor com suspense do que viria de leitor. O dia terminou muito rapido. sai apressado depois do almoço. Peguei um volume das obras completas de Vitor Hugo para ler no caminho até o carro. A pressa foi tanta que peguei o volume 22.[meio de historia, parece livro didatico..ninguém merece] mesmo assim li um pedaço do meio de uma historia para a pequena Anne enquanto subiamos a ladeira até o carro. Atrasadissimo mas bem feliz. 


\section{ANEXO 9}

Afinal: empresta ou não empresta?

2009 setembro 19

by biblio 20

Existe uma certa tendência dentro das bibliotecas - principalmente das escolares - de que nem todo acervo seja emprestado.Talvez, isto seja um sinal de que fungos, traças e mofos possam também ter acesso aos livros.

De acordo com Ranganathan todo livro é pra ser usado.Mas então por que nem todos são emprestados???Por que comprar um livro e depois colocar que o mesmo não pode ser emprestado?

A desculpa mais usada, talvez, seja a de que as crianças irão destruir o livro e por isso é melhor conservá-lo trancafiado dentro dos armários.E nisso tudo o que mais me preocupa é que essa tendência não se restringe apenas às bibliotecas.Orgãos municipais, estaduais e federais costumam, vez ou outra, aparecer nos noticiários sendo acusados de armazenar alimentos, livros , computadores ao ponto de deixá-los inutilizados pela população.

Esse vício "'anti-primeira lei da biblioteconomia" deveria ser extinto em âmbito nacional.Se este não for possível,dadas nossas proporções, que seja pelo menos no âmbito das bibliotecas.

from $\rightarrow$ Missão bibliotecário, Não vem que não tem, Panorama nacional 


\section{ANEXO 10}

Biblioteca escolar:algumas considerações

2009 julho 7

by biblio 20

Estamos - ou pelo menos estávamos - discutindo durante este semetre a situação da bibliotecas escolares brasileiras e, que por sinal, todos nós já conhecemos.Pois bem, o grupo do qual eu fazia parte ficou responsável por observar a produção científica sobre biblioteca escolar no Brasil.

Os resultados foram os seguites:a área da Educação (pedagogia e cursos afins) responde por mais da metade da produção acadêmica sobre biblioteca escolar; os estados da região Norte/ Nordeste apresentam de uns tempos pra cá expressiva participação na produção científica, apesar da maioria das teses e dissertações ainda serem produzidas na região sudeste e, por último, grande parte dos pesquisadores possuem vivência anterior na área de educação, mediação da leitura e biblioteca escolar.

Para eu que acompanho de perto a situação de uma biblioteca escolar, poderia dizer que os resultados, ainda que os mesmos não mensurem quantativamente a realidade de fato, nos indicam que há uma mudança quanto a valorização desse espaço no âmbito escolar.É lógico que existem problemas que só servem para degradar a educação já tão sucateada, como por exemplo a "rixa" (não generalizando, é claro) entre profesores e bibliotecários, vista nitidamente em muitas escolas.

Mas acredito que a produção e explanação da biblioteca escolar tende a aumentar daqui pra frente, até mesmo por causa da aderência de pesquisadores de outras áreas.O que não acredito, e isso serve pra educação como um todo, são em ações de cunho explicitamente filantrópicos, como por exemplo encher os alunos com kits de livros( que posteriormente são queimados, jogados no lixo e etc) desejando que os mesmos leiam a qualquer custo, quando na verdade a prática de leitura está anos-luz de distância destes por razões de cunho social, econômico e familiar.

from $\rightarrow$ Informação e Sociedade, Librarianship aqui, Missão bibliotecário 
ANEXO 11

QUINTA - FEIRA, 10 DE DEZEMBRO DE 2009

\section{"Escolas deveriam ter biblioteca na grade curricular"}

Na boa, disso eu já sei faz é tempo! Mas, de qualquer maneira, me alegro ao ver que pouco a pouco, pessoas de expressão em nosso país tomam consciência da importância da biblioteca numa escola. Basta agora, essas mesmas pessoas aliadas aos profissionais de bibliotecas se empenharem em levar ao resto da sociedade essa mesma constatação.

(Notícia retirada do Publishnews, 10/12/09)

No comando de duas das mais importantes instituições do mundo do livro no Brasil - o Sindicato Nacional de Editores de Livros (Snel) e o Instituto Pró-Livro -, a editora Sônia Jardim vê inúmeros avanços na questão do livro e da leitura nesta década no País. Do lado do governo, cita a criação do Plano Nacional do Livro e Leitura (PNLL) e a maior articulação entre os ministérios da Cultura e Educação, além da desoneração fiscal. Dos editores, lembra do apoio às políticas públicas, da pesquisa Retratos da Leitura no Brasil e dos esforços para baratear o preço dos livros, como o lançamento das coleções de livros de bolso. "Entretanto, ainda não foi suficiente", adverte ela. E cita como exemplo o grande número de alunos que saem da escola sem ter adquirido o prazer ou o hábito de ler. "Na minha opinião, a escola deveria ter uma hora de biblioteca na grade curricular, como um momento de prazer num ambiente agradável", completa. Confira a entrevista completa concedida por Sônia à Agência Brasil que Lê. (Agência Brasil Que Lê).

\section{Leia mais}




\begin{abstract}
ANEXO 12
Prezados colegas

Queremos realizar a Campanha do Silêncio em nossa biblioteca, sendo assim, aceito sugestões.

Gostaria de saber quais os procedimentos adotados em relação ao barulho dentro da biblioteca, principalmente quando os alunos utilizam as salas de estudo em grupo para conversarem alto.
\end{abstract}

\title{
Re: [bibamigos] Silêncio na Biblioteca
}

Olá Michelle,

Para ser bem sincera com você eu acho que este tipo de regra ou norma para biblioteca afeta muito a aceitação dos alunos para com o espaço.

Temos que incentivar o uso da biblioteca e estas ações fazem com que a mesma se torne um ambiente chato sendo que é de fundamental importancia que a biblioteca seja um espaço, além de conhecimento, de convivência e interação entre os usuários.

Talvez para amenizar um pouco o barulho você possa fazer um trabalho de conscientização com os alunos, juntamente com o corpo docente da instituição, mostrando-lhes que é possível interagir e se comunicar na biblioteca sem prejudicar as outras pessoas. É um trabalho difícil mais que terá resultados muito mais satisfatórios. Falo isso por experiência própria.

Boa sorte,

\section{Re: [bibamigos] Silêncio na Biblioteca}

Michelle faz a brincadeira da vaca amarela rssss...

Desculpas pela brincadeira, mas já passe por isso, e sempre teve um ou outro brincalhão que ficava fazendo mais barulho que antes, acho que deve sim colocar avisos, mas pelo que sei instituições particulares não adianta muito tais avisos. Minha opinião.

\section{Re: [bibamigos] Silêncio na Biblioteca}

Colegas

Falando em Silêncio...

Hoje, dia 07/05 é comemorado o Dia do Silêncio

abraços

\section{Re: [bibamigos] Silêncio na Biblioteca}

Eu e os alunos odiamos a turma do psiu(tenho 45 e trabalhei numa biblioteca escolar por 6 meses como estagiario). Isto não quer dizer que todos tem que aceitar a algazarra que os alunos podem fazer na biblioteca. se vc tiver espaço, divida em ala dos falantes e não falantes. ao inves da placa proibido conversar ou algo do genero(que eles odeiam) coloque PERMITIDO FALAR NA ALA DOS FALANTES....mas aqui o povo não quer barulho...ou algo assim, ao inves de proibir, permita algo que os leve a uma concientização ou eles odiarão a biblioteca cada vez mais. seja dos nossos...lute contra "as 
tia" do psiu e combata o que incomoda com politica e inteligencia e não com plaquinhas autoritarias e ações militaristas.desculpa se o tom foi sarcastico, é que eu sei o quanto os alunos odeiam o PSIU e tenho que falar por eles...

\section{Re: [bibamigos] Silêncio na Biblioteca}

Oi Michele,

Concordo também com a transformação do espaço da biblioteca em discussões e debates de grupos. Gosto do ambiente movimentado, e geralmente não cobro silêncio quando não há alunos estudando.

Mas já trabalhei numa biblioteca com grande fluxo de alunos (mais de 1.000 por dia) e lá tínhamos que fazer sempre campanhas de silêncio. O legal é que eu tinha o apoio e ajuda de toda a equipe.

Já fiz várias campanhas, mas listo para você algumas que realmente deram certo: - Periodicamente lançar campanha do silêncio (você pode estabelecer um período: por mês, bimensalmente, etc), com material informativo, planfletos nos murais, e confeccionar camisas para os funcionários com uma frase de conscientização. Você vai ver que não é muito caro.

- Os avisos nas mesas tem que ser beeem pequenininhos...pois avisos de tamanho normal não o fazem ler...avisos pequenos despertam a curiosidade e com certeza todos lerão e ficarão cientes da regra. Caso façam barulho, estão fazendo de propósito...

- Mobilizar um funcionário e fornecê-lo cartões: verde, amarelo e vermelho.

Quando alguém tiver fazendo barulho a pessoa chega e mostra o cartão amarelo, que adverte o usuário de forma mais sutil. $\mathrm{O}$ cartão vermelho adverte o usuário que "passou dos limites". É uma forma que causa impacto e somente o usuário sabe do que se trata, sem constrangê-lo perante os outros. O cartão verde por sua vez é entregue ao usuário que fez silêncio, em forma de marcador de livro, com uma frase parabenizando-o pelo bom uso da biblioteca. Com certeza dissemina a boa ação entre os colegas.

Esse último projeto não é meu, mas foi apresentado num encontro de bibliotecários. A Bibliotecária disse ter resolvido o problema no período de provas. Tenho o arquivo com os modelos e as frases, se você quiser me passe um e-mail pessoal.

Mas de qualquer forma seria bom oscilar entre períodos de silêncio (como por exemplo no período de provas) e uma certa liberação de conversa na biblioteca. Os usuários tem que ser impactados com o bom senso, e não fazerem silêncio obrigatoriamente. É importante criar uma idéia que explique o porquê. É minha opinião!

Beijos! 


\section{ANEXO 13}

Re: [bibamigos] ajuda-biblioteca escolar

Eu adoro o universo da biblioteca escolar. Se um dia puder me custear até trabalho em uma porque pagam muito mal. (cerca de 1000 a 1300 contos....por oito horas de trampo...vich, só pra quem pode ter um salario destes depois de estudar 5 anos) Bom, mas fui estagiário da biblioteca da escola onde minha filha estudava, um estagiário que cuidava da biblioteca e cuja bibliotecaria "responsável" ficava em outra unidade. Isto era bom,me dava liberdade e eu inventava muito.Ficava, ao invés de polirndo o acervo para ninguém, engenhando formas e formas de captar seguidores das boas letras. Era como planejar de que lado iria armar a teia de aranha para pegar minhas "vitimas". Colocava recados importantes pregados com desenhos engraçados no monitor dos computadores, eu sabia que ali eles iriam ler...até poesia liam assim. Espalhava pilhas de livros(os de capa dura e portanto, mais resistentes) pelo pátio para que eles tropeçassem na hora do recreio(assim perceberam que existiam vida por tras do balcão da biblioteca...) Colava poesias no piso, perto do banco onde eles sentavam e cobria com contact(sabe como é, sentou ali, nada pra fazer...o que é isto aqui no chão?), mantinha minhas mascaras de gesso á mão para que eles brincassem com elas de teatro, usava uma maquina velha de slides para contar historias ou lendas classicas e tem até filme da dança do caranguejo dentro da biblioteca.Indicava livros com titulos interessantes como "tem uma lagartixa dentro do meu computador" ou "como educar seus pais".(eram os mais lidos tirando a série Goosebumps e Harr Poter). Bom, se eu pudesse resumir diria que a biblioteca escolar é a casa da invenção, como diz o Titulo do Prof. Milanesi. Mas não pode desanimar porque a verdade é que os alunos não gostam de ler, ao menos a maioria. Com minhas invenções já vi muitos milagres acontecerem. (tipo o aluno mais bagunceiro da escola ler algo que nunca leria antes..."Como educar seus pais" ou sobre a vida do rei Arthur. em primeiro lugar tirei a mania deles me chamarem de tio $e$ fui insistindo até que me chamassem pelo nome. Tenho 46 anos, mas pedi que não me chamassem de senhor. Eu precisava me aproximar deles e "senhor" deixa vc mais longe. Nesta época, comprei um skate e comecei a aprender a andar....dai tinha assunto com alguns que sabiam andar de skate; Colocava quadros que pintei no meio do pátio com frases como: "leia isto" ou "você já leu um quadro?". eu acho que sou tão fascinado pela biblioteca escolar que poderia escrever um livro que se chamaria: "As peripécias de um bibliotecário maluco para captar leitores ariscos em uma biblioteca escolar". Sempre odiei o psiu, eles podiam trocar idéias e sempre o faziam dentro da biblioteca. A moderação era um pedido e não uma ordem. ao invés de "proibido conversar", ou "silêncio" a placa era: Permitido falar baixo.(vou parar por aqui ou corro o risco de não ser lido até o fím...)

bom, estou enviando links para alguns do meus blogs da época.Se quiser mais alguma informação terei prazer em dizer o que penso deste maravilhoso universo da biblioteca escolar.Dá uma passadinha lá. 
Boa tarde,

Vou te dar a minha impressão de criança que frequentou biblioteca escolar quando este termo não era ainda disseminado. Meu interesse pelos livros começou justamento porquê uma professora, ainda no Jardim de Infância, expôs alguns livros muito atrativos, coloridos, e de tamanhos variados em local de fácil acesso e sem burocracia para nós alunos, ainda aprendendo a ler. Esta experiência modificou minha vida, a ponto de eu e meus amigos ao longo da vida escolar procurarmos sempre pela biblioteca da escola, uma salinha um pouco suja e desarrumada, isto se deu até entrarmos no ensino médio. Traduzindo, como usária apaixonada identifiquei sempre primeiro, boa vontade, atenção e pouca burocracia.

Por mais que a biblioteca seja farta de acervo, tenha tecnologia disponível, o que conta é o ser humano por tras "do balcão". Este é o fator que vai fazer o usuário voltar ou não.

Amigos, em março/2010 iniciarei o trabalho em uma biblioteca escolar e já comecei a estudar mais sobre o tema, as particularidades dessa instituição e questões conceituais, pois a prática de catalogação, classificação eu já tenho. Por isso, gostaria que vocês me falassem um pouco sobre a biblioteca escolar: o que vocês pensam sobre ela? Vocês conhecem boas bibliotecas escolares? E o bibliotecário escolar, existe?

Obrigada a todos e boas festas! 